\title{
Экономическая социология
}

электронный журнал

www.ecsoc.msses.ru

Tом 3, № 3, 2002

Главный редактор журнала - Радаев Вадим Валерьевич, д. э. н, зав. кафедрой экономической социологии ГУ-ВШЭ, проректор ГУ-ВШЭ; директор Интерцентра Московской школы социальных и экономических наук.

Email: radaev@hse.ru

Редактор журнала - Добрякова Мария Сергеевна, к. социол. н.

Email: mdobryakova@,fordfound.org

Администратор сайта - Лукьянчук Михаил Борисович, аспирант ГУ-ВШЭ

Email: lukyanchuk@hse.ru

Информационная поддержка - Новикова Елена Геннадьевна, аспирант ГУ-ВШЭ.

Email: neg@msses.ru

Проект осуществляется при поддержке

Московской высшей школы социальных и экономических наук // www.msses.ru

Журнал выходит пять раз в год:

№ 1 - январь,

№ 2 - март,

№ 3 - май,

№ 4 - сентябрь,

№ 5 - ноябрь. 


\section{Содержание}

Вступительное слово главного редактора..............................................

$\underline{\text { Интервью }}$

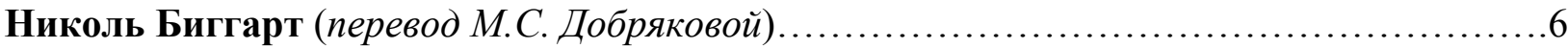

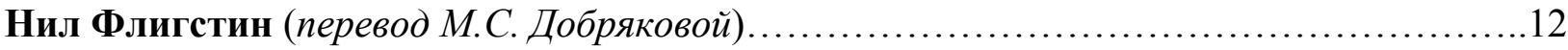

Новые тексты

Радаев В.В. Еще раз о предмете экономической социологии .........................21

Волков В.В. Силовое предпринимательство в современной России. Глава $4 \ldots \ldots \ldots \ldots . . .35$

Новые переводы

Грановеттер Марк. Экономическое действие и социальная структура: проблема укорененности (перевод М.С. Добряковой)...

Взгляд из регионов

Балабанова Е.С. Стратегии совладания с жизненными трудностями: самостоятельность

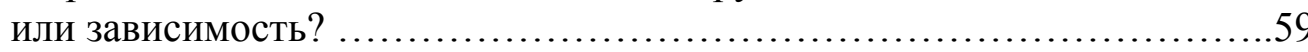

Дебютные работы

Алексеев В.В. Агрессивный менеджмент: практика утилитарной этики

Профессиональные обзоры

Рона-Тас А. Экономическая социология в Европе: Венгрия (перевод М.С.Добряковой) .........102

Писляков В.В. Зарубежные электронные журналы для экономсоциологов ............. 111

Новые книги

Асперс П. Рынки в сфере моды: феноменологический подход

(Й. Рёссель, перевод М.С. Добряковой).

Малева Т.М. (ред.) Зарплата и расплата: проблемы задолженности по оплате труда (Т.М. Малева)

Исследовательские проекты

Корнев Н.Р. Социально-пространственная дифференциация населения Санкт-Петербурга

Рязанцев С.В. Миграционная подвижность экономически активного населения российской провинции в контексте формирования новых жизненных стратегий.......130

Учебные программы

DiMaggio Paul. Economic Sociology

Конференции

Конференция, посвященная 10-летию «Российского Экономического Барометра» (И.А. Баширова).

Российский мониторинг экономического положения и здоровья населения (RLMS) (И.Б. Назарова).

3-я Международная конференция ГУ-ВШЭ «Модернизация экономики России: итоги и перспективы». Секция 2: Институциональные и структурные реформы .............149

$6^{\text {th }}$ Conference of the European Sociological Association 


\section{$\boldsymbol{V R}$ Вступительное слово главного редактора}

Дорогие коллеги, у нас первый юбилей!

Это десятый номер нашего журнала. Десятый раз мы выходим в свет в строго определенное время. Мы не потеряли ни одной из объявленных в начале сквозных рубрик, более того, по пути приобрели пару новых рубрик, которые также стали постоянными. Согласитесь, в наше время разрушения всякого постоянства и регулярности это некоторое достижение. Мелочь, а приятно.

Но главное, конечно, это новые тексты и материалы, которые подготовлены для юбилейного номера. Почти в каждой рубрике нас ожидает какое-то событие.

В нашей первой рубрике «Интервью» публикуются две беседы с ведущими специалистами по новому институционализму в социологии и теории организаций.

Первая - с Николь Биггарт (Университет Калифорнии, Дэвис, США), одним из наиболее интересных специалистов в сравнительных исследованиях хозяйственных организаций. Статья проф. Биггарт уже публиковалась у нас в журнале ${ }^{1}$. Ее перевод выйдет в книге: Экономическая социология: новые подходы в институциональном и сетевом анализе / Под ред. В.В. Радаева. М.: РОССПЭН, 2002. До этого проф. Биггарт выступала у нас в Москве на конференции «Экономическая социология на пороге третьего тысячелетия» (январь 2000 г.) (о конференции см.: Том 1, № 1. С. 130-135).

Второе интервью - с Нилом Флигстином (Университет Калифорнии, Беркли, США), автором так называемого «политико-культурного» подхода к анализу рынков. Его материал об институциональных подходах уже размещался в нашем журнале ${ }^{2}$ и готовится к публикации в книге: Экономическая социология: новые подходы в институциональном и сетевом анализе. Годом раньше проф. Флигстин выпустил новую книгу «Архитектура рынков» (2001), которая, несомненно, стала событием в экономической социологии.

Рубрика «Новые тексты» открывается нашей программной статьей о предмете экономической социологии. С момента первого опубликования книги «Экономическая социология: курс лекций» в 1997 г. утекло немало воды. И предлагаемый материал существенно развивает и упорядочивает положения, высказанные ранее в книге. До конца 2002 г. он будет опубликован в журнале «Социологические исследования».

Мы также с удовольствием объявляем о публикации четвертой главы новой книги Baдима Волкова о силовом предпринимательстве. На наш взгляд, это одна из наиболее интересных глав, она посвящена эволюции воровского мира под воздействием приходящей ему на смену бандитской культуры.

В рубрике «Новые переводы» предлагается перевод первой части статьи, которая является самым цитируемым текстом в современной экономической социологии. Это статья Марка Грановеттера про embeddedness («Экономическое действие и социальная структура: проблема укорененности»). Добавим, что это первый из известных нам русских

${ }^{1}$ Биггарт H. Социальная организация и экономическое развитие (Том 2, № 5, 2001. С. 4958; Biggart, Nicole Woolsey. Social organization and economic development, (Тoм 1, № 1 , 2000. C. 6-12).

2 Флигстин H. Поля, власть и социальные навыки: критический анализ новых институциональных течений (Том 2, №4, 2001. C. 28-55); Fligstein, N. Fields, Power, and Social Skill: A Critical Analysis of The New Institutionalisms, (Том 2, № 1, 2001. C. 4-25). 
переводов Грановеттера - признанного лидера новой экономической социологии. Полный перевод текста, предлагаемого в данном номере, увидит свет позднее - в рамках подготавливаемой нами хрестоматии «Западная экономическая социология».

В рубрике «Взгляд из регионов» размещена работа Е.С. Балабановой (Нижний Новгород). Мы вновь возвращаемся к проекту о стратегиях совладания. Предыдущие работы можно посмотреть в нашем журнале 3

Размещаемый в рубрике «Дебютные работы» текст - доработанный фрагмент магистерской диссертации В.В. Алексеева. Работа подготовлена автором в Центре социологического образования Института социологии РАН (2000-2001 гг.) и посвящена исследованию агрессивных практик управления.

В рубрике «Профессиональные обзоры» предлагается очень интересный для нас материал - «Экономическая сочиология в Венгрии», переведенный из Европейского Ньюслеттера «Экономическая социология» (автор - A. Рона-Тас). Венгерская экономическая социология по праву занимала лидирующее положение в странах Центральной и Восточной Европы. Их опыт очень важен для нас. А даваемые автором (венгром, проживающим в США) трезвые оценки невольно заставляют задуматься о наших собственных проблемах.

В этом номере нас ожидает необычный обзор электронных ресурсов. Он подготовлен профессионалом в области электронных библиотечных ресурсов B.B. Писляковым (ГУВШЭ). Из него, в частности, можно узнать, где найти электронные версии ведущих экономико-социологических журналов и как они представлены в крупных электронных системах библиотечного поиска.

В разделе «Новые книги» предлагаем вашему вниманию перевод рецензии на новую книгу П. Асперса (Швеция) «Рынки в сфере моды: феноменологический подход» (2001). Асперс - способный молодой исследователь, один из тех, кто уже третий год координирует работу Европейской исследовательской сети «Экономическая социология».

Другая книга (Зарплата и расплата: проблемы задолженности по оплате труда / Под ред. Т.М. Малевой) посвящена одному из наиболее загадочных явлений российского рынка труда 1990-х гг. Чем объяснялись хронические неплатежи и задержки заработной платы, почему менеджеры и работники мирились с подобной ситуацией - об этом рассуждают лучшие отечественные и зарубежные авторы по проблемам российской занятости. В нашем журнале уже затрагивалась данная тема ${ }^{4}$. Учитывая звездный состав авторов и загадочность проблемы, настоятельно советуем прочитать данную книгу.

В рубрике «Исследовательские проекты» мы знакомим вас с двумя очередными проектами Независимого института социальной политики. Один проект посвящен исследованию социально-пространственной дифференциации населения СанктПетербурга (руководитель - Н.Р. Корнев, Санкт-Петербург). Другой - трудовой миграции населения в российской провинции (руководитель С.В. Рязанцев, Ставрополь).

Далее мы размещаем «Учебную программу» Пола Димаджио «Экономическая социология». Профессор Димаджио - один из самых известных людей в экономической социологии. Это специалист потрясающе широкого диапазона. Он известен работами по

${ }^{3}$ См.: Демин А.Н. Возможности использования человеком индивидуальных и социальных ресурсов в ситуации отсутствия работы (Том 1, № 1, 2000); Петрова Л.Е. «Новые бедные» ученые: жизненные стратегии в условиях кризиса (Том 2, № 1, 2001); Радаев B.B. Работающие бедные: велик ли запас прочности? (Том 1, № 1, 2000).

${ }^{4}$ См.: Радаев B.B. Работающие бедные: велик ли запас прочности (Том 1, № 1, 2000); Капелюшников Р.И. Российский рынок труда: адаптация без реструктуризации (Том 2, № 2, 2001). 
социологии организаций и новому институционализму, экономической социологии культуры и когнитивной социологии. Его программа заслуживает самого пристального внимания.

В рубрике «Конференции» подготовлен обзор выступлений на конференции, посвященной 10-летию «Российского экономического барометра» (16-18 апреля 2002 г., Москва), и конференции по результатам работы Российского мониторинга экономического положения и здоровья населения (RLMS) (14-15 мая 2002 г., Москва).

Мы публикуем краткую информацию о еще двух конференциях.

3-4 апреля 2002 г. состоялась 3-я Ежегодная международная гранд-конференция Государственного университета - Высшей школы экономики «Модернизация экономики России: итоги и перспективы». На пленарном заседании по традиции выступали высшие правительственные чины и олигархи. Мы же обращаем внимание на программу наиболее интересной для нас секции «Институциональные и структурные реформы».

Наконец, размещается информация о готовящейся конференции Европейской социологической ассоциации «Стареющие общества, новая социология» (25-28 сентября 2003 г., Испания).

С первым юбилеем нас всех! Ура!!! 


\section{Интервью}

$\boldsymbol{V} \boldsymbol{R}$ Публикуются две беседы с ведущими специалистами по новому институционализму в социологии и теории организаций.

Первая - с Николь Биггарт (Университет Калифорнии, Дэвис, США), одним из наиболее интересных специалистов в сравнительных исследованиях хозяйственных организаций. Статья проф. Биггарт уже публиковалась у нас в журнале ${ }^{1}$. Ее перевод выйдет в книге: Экономическая социология: новые подходы в институциональном и сетевом анализе / Под ред. В.В. Радаева. М.: РОССПЭН, 2002. До этого проф. Биггарт выступала у нас в Москве на конференции «Экономическая социология на пороге третьего тысячелетия» (январь 2000 г.) (о конференции см.: Том 1, № 1. С. 130-135).

Второе интервью - с Нилом Флигстином (Университет Калифорнии, Беркли, США), автором так называемого «политико-культурного» подхода к анализу рынков. Его материал об институциональных подходах уже размещался в нашем журнале ${ }^{2}$ и готовится к публикации в книге: Экономическая социология: новые подходы в институциональном и сетевом анализе. Годом раньше проф. Флигстин выпустил новую книгу «Архитектура рынков» (2001), которая, несомненно, стала событием в экономической социологии.

\section{Николь Биггарт. 21 сентября 2001 г. $^{3}$}

Интервью с Николь Биггарт состоялось в Центре Восточно-европейских и азиатских исследований в Беркли после моего доклада на семинаре Центра. Николь любезно приехала на этот семинар, благо она живет относительно недалеко от Беркли. Нам выделили свободную комнату. В ходе разговора, помимо интервью, она с увлечением рассказывала о своем новом исследовательском проекте, связанном с изучением рынка строительной индустрии в Калифорнии. Как всегда, Николь очень четко излагает свои мысли...

- Николь, я полагаю, Вы считаете себя экономсочиологом. Но скажите, с чего это началось, когда Вы впервые осознали себя в этом качестве и сказали: «Да, пожалуй, я занимаюсь экономической соииологией»?

- Думаю, это было в середине 1980-х гг. Я работала социологом в бизнес-школе. Причем это была маленькая бизнес-школа, где не было деления на факультеты. Так что моими коллегами были экономисты, бухгалтеры, люди из других дисциплин. Но в большинстве своем это были люди, которые работают в дисциплинах, основанных на экономической теории в качестве базы для анализа (будь то финансы, или бухгалтерский учет, или международная экономика), - все они так или иначе экономисты. И для меня это был очень странный мир. Они говорили на другом языке, они смотрели на мир иначе, чем я. И тем не менее, мы изучали одни и те же или связанные между собой явления. Я изучала фирмы, и некоторые из них говорили мне, что они тоже изучают фирмы. Но я никак не

${ }^{1}$ Биггарт Н. Социальная организация и экономическое развитие (Том 2, № 5, 2001. С. 4958; Biggart, Nicole Woolsey. Social organization and economic development, (Том 1, № 1, 2000. C. 6-12).

2 Флигстин H. Поля, власть и социальные навыки: критический анализ новых институциональных течений (Том 2, №4, 2001. С. 28-55); Fligstein, N. Fields, Power, and Social Skill: A Critical Analysis of The New Institutionalisms, (Том 2, № 1, 2001. C. 4-25).

${ }^{3}$ Перевод М.С. Добряковой. 
могла увидеть фирмы в том, что они делали. Это был интересный опыт, при этом он подчеркивал различия между нами. Ведь они казались так уверены в том, что они делали. У них было очень четкое представление о себе и своей работе. А я по образованию социолог, и меня учили не быть уверенной, а идти и исследовать окружающий меня социальный мир. Они были уверены в себе, а я была настроена на открытие нового. Если честно, то для молодого ученого это была весьма неуютная обстановка. Может быть, отчасти потому, что я была женщиной, а они все - мужчинами, и здесь играли роль и гендерные моменты. Так вот, я не скажу, что они смеялись надо мной, но моя работа не получала серьезной поддержки. Они были уверены, что я не ученый, что я не получила должной подготовки. Знаете, они вообще не могли объяснить толком, почему они пригласили меня на работу.

Однако, будучи социологом, я решила воспринимать их как еще один объект для исследования. И начала изучать экономистов и экономическую теорию, чтобы понимать их лучше. Так что именно в процессе изучения того, почему экономисты столь истово верят в свои аналитические посылки и аксиомы, я и поняла, что стала экономсоциологом. Да, я занималась изучением хозяйства. Однако, вне всякого сомнения, не так, как это делал бы экономист. И тогда я почувствовала себя намного лучше. Я поняла, что они закрылись от стольких возможностей. И я обнаружила, что мир открыт передо мной.

- Не могли бы Вы назвать несколько основных методологических подходов, которые, с Вашей точки зрения, образуют нынешнюю экономическую сочиологию? Основные направления исследований?

- Думаю, экономическая социология использует все поле методологии. Полагаю, интересные вещи в экономической социологии делаются в рамках сравнительного исторического подхода. Здесь, без сомнения, интересны работы Брюса Каррутерса [Bruce Carruthers]. Есть и количественные исследования - например, крупные базы данных, позволяющие проследить изменения в фирме в течение времени. Есть также сетевые подходы к исследованию рынков. Они используются, конечно, не только экономической социологией. Сетевой подход - это одновременно и общая методология, и теоретическая перспектива. Затем полевая работа, наверное (я сама провожу много полевых исследований). Не думаю, что экономическая социология имеет жесткую методологическую схему. Наверное, в гораздо большей степени она определяется стремлением понять социальную основу хозяйственной деятельности.

- Пожалуй, я согласен. А новые институциональные течения в сочиологии Вы поместили бы отдельно от других подходов? Вообще этих течений много?

- Есть много новых институциональных течений. И я даже, буквально только что, написала, в соавторстве с Доном Палмером, обзорную главу по новому институционализму. Было очень интересно работать с коллегой, занимающимся совершенно другой формой институционализма, чем я. Мы считали разные работы основными и важными для нового институционализма. Но я думаю, что новые институциональные течения или даже все институциональные течения имеют общий фундамент постольку, поскольку они рассматривают хозяйство и хозяйственные организации как социальную конструкцию. По многим другим параметрам между ними есть множество различий. Однако, думаю, есть одна вещь, по поводу которой все они сходятся во мнении: мир - это социальная конструкция, и неважно, сформулировано ли это в форме легитимности или происходит на уровне подражательного изоморфизма [mimetic isomorphism]. Дело действительно в способах конструирования правил, конвенциональных подходов, практик, определяющих функционирование хозяйства. И новые институциональные течения на самом деле занимаются изучением социального конструирования хозяйственной деятельности и хозяйственных организаций. 
- А какие недавние работь - книги или статьи - по экономической социологии показались Вам чем-то примечательными, необычными, неожиданными, озадачивающими, новаторскими, если брать последние два-три-четьре года?

- Например, я только что купила новую книгу Нила Флигстина и начала ее читать. Думаю, это очень хорошая книга - «Архитектура рынков». ${ }^{4}$ Нил проделал большую работу, исследуя рынки. Эта работа не только по экономической социологии. Она именно о рынках. Рынки - ее важный аспект, но это еще не вся экономическая социология. Думаю, это будет неожиданная и в какой-то степени неоднозначная точка зрения на рынки, попытка выдвинуть предположения, разработать более кумулятивное знание, которое можно проверить эмпирически и которое потенциально может даже использоваться политиками [policy makers]. Так что это первая книга, которую я выделила бы.

Другая работа, которая кажется мне совершенно удивительной, - это работа Вивианы Зелизер. Ее самая последняя книга - «Социальное значение денег». Очень хорошая работа.

- Да, она мне тоже очень нравится, но ведь она появилась достаточно давно.

- Ну, четыре года назад. Не раньше. А, нет, Вы говорите о более ранней книге... Ладно, Вы думаете, это слишком давно.

- Вы упомянули раньше Брюса Каррутерса?

- Да, но его книга появилась, думаю, лет шесть назад.

- Которая? Тогда Вы говорите о его книге по истории, а она не последняя.

- Нет-нет, не об учебнике ${ }^{6}$. Мне очень нравится его книга о развитии финансовых рынков в Англии ${ }^{7}$ В экономической социологии ведется большая дискуссия: государства ли формируют рынки или рынки - государство? Несомненно, это важный вопрос. Создают ли государства рыночную инфраструктуру - денежные единицы, регулирующий аппарат и многие другие вещи, позволяющие рынку соответствовать сложившейся в стране правовой системе? Или, наоборот, капиталистический правящий класс конструирует государство с целью создания стабильных условий? В этой связи мне очень нравится книга Брюса, она очень исторична, в ней рассказывается об основании финансовых рынков в Лондоне, о том, как они появились, показывается, как рынки были вовлечены в работу Королевского казначейства [King's Treasury] и создавали условия для участия государства (в данном случае, короля) в политических интригах [machinations]. Это очень хороший пример исторической эмпирической работы, здесь не просто утверждается: «О, это государство; ах, нет, это рынок». Здесь действительно анализируются исторические материалы. Так что это очень хорошая книга.

- А какие-то статьи можете назвать?

${ }^{4}$ Fligstein, Neil. The Architecture of Markets: An Economic Sociology of Twenty-First-Century Capitalist Societies. Princeton: Princeton University Press, 2001.

${ }^{5}$ Zelizer, Viviana. The Social Meaning of Money. Princeton, N.J.: Princeton University Press, 1997.

${ }^{6}$ Carruthers, Bruce G. and Sarah L. Babb. Economy / Sociology: Markets, Meanings, and Social Structures.Thousands Oaks, CA: Pine Forge Press, 2000.

${ }^{7}$ Carruthers, Bruce G. City of Capital: Politics and Markets in the English Financial Revolution. Princeton: Princeton University Press, 1996. 
- Да, я как раз собиралась сказать, что значительная часть экономической социологии развивается в форме статей. Хотя есть несколько очень хороших книг, но не думаю, что они вышли совсем уж недавно. Например, есть одна книга (правда, она старше, она вышла лет пять назад)... Не думаю, что социологи обратили на нее особенное внимание. Но мне кажется, в ней есть немало для социологов - я имею в виду книгу Сторпера и Сале «Миры производства». Вы знаете ее?

- Hem.

- Авторы - Майкл Сторпер [Michael Storper] и Робер Сале [Robert Salais]. ${ }^{8}$ Сторпер очень хорошо образован, это широко известный социальный географ, интересующийся региональными экономиками. А Робер Сале - французский экономсоциолог, работающий в традиции экономики конвенций. Мне кажется, эта книга начинает обращать внимание (и я думаю, это очень и очень интересно) на «миры производства». Ведь развиваются мир или культура, культура и локальные институты, создающие особые типы экономических отношений и возможностей. Почему французы производят духи и занимаются высокой модой, немцы - машиностроением, а швейцарцы - международным банковским делом [international banking]?

\section{- И шоколадом.}

- Верно, и шоколадом. В чем здесь дело? Ведь не культура же заставляет швейцарцев производить шоколад. Хотя я уверена, что их культурная фразеология [cultural expressions] связана с шоколадом. Но важно посмотреть, как в действительности исторические факторы, институты и образцы отношений, складывающиеся в различных обществах, в конечном итоге превращаются в институционализированные наборы возможностей и институциональные структуры, обеспечивающие данному обществу преимущества на уровне мировой экономики. Это побудило меня взглянуть на хозяйство по-новому. Ведь обычно мы смотрим на него сверху вниз: вот, есть структура, давайте поглядим, к каким различиям она ведет на уровне реальных действий индивидов. А они показали мне другое направление - взгляд снизу. Вот, нам известно нечто о взаимодействиях и типах отношений - но каким образом они инстуционализируются, преващаются в структуры, оказывающие затем влияние на более общий хозяйственный контекст? Так что мне нравится эта книга.

- И мой последний вопрос: какие темы и направления исследований в экономической социологии кажутся Вам наиболее перспективными в ближайшем будущем?

- Прежде всего, одна тема. Я начала с того, социология рынков не тождественна экономической социологии. Но в целом это та область, куда экономическая социология вложила немало сил и времени. И тому есть веские причины. Мы стремимся понять действительно фундаментальный элемент капитализма. Постсоциалистические экономики пытаются построить рынки. Так что исследование рынков будет образовывать насколько мне видится обозримое будущее - ядро экономической социологии.

Теоретически экономисты тоже интересуются рынками. Правда, их рассуждения и гипотезы касаются совершенных рынков. А затем они идентифицируют несовершенства рынков и пытаются их как-то исправить. А мы попробовали предложить наше видение проблемы и представить рынки как институционализированные наборы связей/отношений [relationships], в которых задействованы права собственности и другие типы социальных структур.

\footnotetext{
${ }^{8}$ Storper, Michael, and Robert Salais. Worlds of Production: The Action Frameworks of the Economy. Cambridge, Mass.: Harvard University Press, 1997.
} 
Однако, я полагаю, для нас важно пойти дальше исследования тех вопросов, которыми занимались экономисты, и посмотреть на весь спектр социальных явлений, фигурирующих в экономической теории. Я действительно думаю, что экономическая социология может исследовать весь спектр таких социальных явлений. Ведь и некоторые классические мыслители - как, например, Вебер - размышляли о связи религии и хозяйства. И мы продолжаем исследовать политическую экономию, связь формы правления и государства с хозяйством.

Опять же, есть проблема связи семейной структуры и хозяйства. Есть авторы, серьезно занимающиеся этим вопросом. Есть исследователи развития, анализирующие то, как индустриальное развитие изменяет семейные отношения. Причем экономсоциологи исследуют эту проблему, как правило, в развивающихся странах и в меньшей степени в развитых странах. Я думаю, что хозяйственная культура, господствующая роль экономики в производстве культуры как товара, продукта столь же важна, сколь и господство рыночного общества, роль рынка для производства особого типа культуры, особого типа рациональности, особого акцента в процессе социализации и образования рациональных индивидов. Хозяйство и общество взаимопроникают друг в друга столь многими способами, что мы даже не могли воспринимать это явление с достаточной серьезностью. И думаю, экономическая социология может пойти именно в этих направлениях. Мы можем обнаружить здесь очень интересные вещи. Так что это одно направление.

А другое направление, которое кажется мне важным для экономической социологии, - это движение в область политики [policy areas]. Это не особенно популярно сейчас среди социологов...

- Вы имеете в виду социиальную политику?

- Экономическую политику. Знаете, у президента США есть Совет экономических консультантов [Council of Economic Advisers]. И все они экономисты. А почему бы не пригласить туда людей, понимающих, как экономика работает на самом деле, чтобы они консультировали политиков? Социологи, по крайней мере в США, очень неохотно вмешиваются в политику. Они говорят: «Мы - как антропологи, мы не любим вмешиваться в жизнь наших племен. Мы предпочитаем не марать руки и оставаться в стороне». Психологи легко идут на практическую работу. Экономисты, вне всякого сомнения, легко дают советы. И политологи не испытывают с этим проблем. Думаю, слишком много вреда произошло от того, что мы позволяли другим дисциплинам пользоваться нашими открытиями - присваивать их и использовать так, как мы, быть может, совсем не имели в виду. Возможно, эти последствия не так широко известны. Так что я бы хотела, чтобы экономическая социология развивала в себе интерес к исследованиям политики.

- Большое спасибо.

\section{Библиография работ Николь Биггарт}

Биггарт H. Социальная организация и экономическое развитие // Экономическая социология, 2001. Т. 2, № 5. С. 49-58 // www.ecsoc.msses.ru.

Biggart, Nicole Woolsey. Social organization and economic development, Экономическая сочииология, 2000. Т. 1, № 1. С. 6-12 // www.ecsoc.msses.ru.

Orrú, Marco, Nicole W. Biggart, and Gary G. Hamilton. The Economic Organization of East Asian Capitalism. Thousand Oaks, Calif.: Sage Publications, 1997.

Biggart, Nicole Woolsey. Models of Management: Work, Authority, and Organization in a Comparative Perspective. Work and Occupations (May 1996). Vol. 23, No. 2. 
Biggart, Nicole Woolsey. Charismatic Capitalism: Direct Selling Organizations in America. Chicago: University of Chicago Press, 1989.

Biggart, Nicole Woolsey and Gary G. Hamilton. An Institutional Theory of Leadership. The Journal of Applied Behavioral Science (1987). Vol. 23, No. 4.

Hamilton, Gary G., and Nicole W. Biggart. Governor Reagan, Governor Brown: A Sociology of Executive Power. N.Y.: Columbia University Press, 1984.

Biggart, Nicole Woolsey and Gary G. Hamilton. The Power of Obedience, Administrative Science Quarterly (Dec 1984). Vol. 29, No. 4.

Biggart, Nicole Woolsey. Management Style as Strategic Interaction: The case of governor Ronald Raegan, The Journal of Applied Behavioral Science (Jul/Aug/Sep 1981). Vol. 17, No. 3.

Hamilton, Gary G., and Nicole W. Biggart. Making Dilettante an Expert: Personal Staffs in Public Bureaucracies. The Journal of Applied Behavioral Science (Apr/May/Jun 1980). Vol. 16, No. 2.

Biggart, Nicole Woolsey. The Creative-Destructive Process of Organizational Change - The Case of Post Office. Administrative Science Quarterly (Sept 1977). Vol. 22, No. 3. 


\section{Нил Флигстин. 19 сентября 2001 г.}

Мне уже приходилось бывать прежде в офисе Флигстина в Беркли. Но на этот раз мы встретились в особой ситуации. Вскоре Нилу предстояла серьезная операция, и последствия были не очевидны. Он был очень открыт и довольно спокойно говорил об этом малоприятном сюжете. Чувствовалось, что он действительно 'confidential' (Впоследствии операция прошла успешно, уверенность оказалась не напрасной). Накануне он подарил мне свою новую книгу, в которой суммированы его основные взгляды. Заглянув в начало книги, сразу начал читать. Редкий случай...

- Bbl, без сомнения, один из ведущих экономсочиологов. Так что, я полагаю, Вы идентифицируете себя именно с этой областью исследований. А с чего это началось? Когда Bы впервые ощутили себя в таком качестве?

- Произошла забавная вещь. Наверное, я всегда был экономсоциологом, просто для этого сначала не было названия. Приходишь в университет, а названия для этого нет. Думаю, так произошло со всеми, кто работает сейчас в данной области: их всегда интересовали вопросы укорененности хозяйства в обществе, и, следовательно, они всегда считали это частью своей работы. Но не думаю, что для таких исследований была выделена специальная область вплоть до... - видимо, пока не появилась статья Хэррисона Уайта [Harrison White], которая заставила всех взглянуть на теорию рынков с социологической точки зрения.

- «Откуда берутся рынки?»

- Да, статья «Откуда берутся рынки?»². Но знаете, я уже тогда думал в этом направлении, делал какую-то работу, я уже практически сформулировал для себя идеи книги, которая вышла в конце 1980-х - начале 1990-х гг. - «Трансформация корпоративного контроля» ${ }^{3}$. Я много читал по истории бизнеса. Так что я тогда уже действительно думал в этом направлении. И наверное, так делали и другие. Я уже думал, что это именно та область, которая меня интересует. Это подходящий ответ?

- Да, вполне.

- Думаю, момент, когда это стало уже коллективным предприятием, наступил позднее пожалуй, в конце 1980-х - начале 1990-х гг. И здесь важную роль сыграла статья Марка Грановеттера [Marc Granovetter] об укорененности ${ }^{4}$. Это было своего рода обобщение [proliferation] многих других работ, сделанных к тому времени, - моих работ и работ других людей, которые также интересовались фирмами и рынками. Многие из них первоначально занимались теорией организаций. И полагаю, что люди, интересовавшиеся теорией организацией, на самом деле были экономсоциологами. Мне кажется, Пол Димаджио [Paul DiMaggio] и Вуди Пауэлл [Walter Powell] на самом деле были экономсоциологами - хотя они и придерживались точки зрения институциональной экономической теории. Их первые работы были посвящены полиграфической и

${ }^{1}$ Перевод М.С. Добряковой.

${ }^{2}$ White, Harrison. Where do Markets Come From, American Journal of Sociology (1981). Vol. 87. P. 517-547.

3 Fligstein, Neil. The Transformation of Corporate Control. Cambridge, Mass.: Harvard University Press, 1990.

${ }^{4}$ Granovetter, Mark. Economic Action and Social Structure: The Problem of Embeddedness, American Journal of Sociology (November 1985). Vol. 91, No. 3. P. 481-510. 
издательской промышленности. Затем Пол много занимался исследованием собственности, при этом его интересовала также структура капитализма. И таких работ было немало, так что к 1980-м гг. уже сложился определенный консенсус. Затем, конечно, сборник Ричарда Сведберга [Richard Swedberg], который он составил на основе интервью и биографических источников. ${ }^{5}$ Думаю, именно тогда мы поняли, что есть такая особая область. Пожалуй, на этом я и остановлюсь.

- Есть разные классификации основных направлений исследования в экономической социологии. А какие области исследования кажутся Вам наиболее важными?

- Я бы сказал, есть три таких области. Две из них пересекаются, третья стоит особняком. К тем, что пересекаются, я отнес бы авторов, занимающихся социологией отдельного рынка или отрасли промышленности. Т.е. люди исследуют фирмы, их связи, иногда - их клиентов, иногда - поставщиков, часто при этом берут за основу сетевой подход. Подобный анализ достаточно распространен. Во многом это исследование социальной структуры промышленности. Так что это первое направление - исследование социальной структуры рынка.

Второе направление более связано с политической экономией: здесь людей интересует роль государства [government] в работе рынка, отношения между рыночными акторами и государственными акторами. Это связано с вопросом о том, как работают конкретные рынки. Это второе направление. При этом первое и второе направления сложным образом переплетаются.

И третье направление для меня (т.е. вообще-то их, видимо, четыре) - то, что я бы назвал направлением, ориентированным на изучение потребления, на социологию потребления. К сожалению, оно менее всего интегрировано в нашу область, что довольно забавно. И, например, Вивиана Зелизер [Viviana Zelizer], одна из представительниц того, что я называю социологией потребления, испытывает те же чувства - по крайней мере, в отношении США. Думаю, проблема отчасти состоит в том, что существует своего рода водораздел между конечными потребителями вещей и их конечными производителями. А это связано в том числе с характером этих исследований, с теорией. Подобное разделение мне кажется неудачным. Например, мне очень интересно и потребление, и производство. Но, видимо, потребление образовало другую группу вопросов, которые люди отложили в сторону. Хотя, конечно, есть работы таких авторов, как Пьер Бурдье [Pierre Bourdieu], в которых потребление рассматривается с социологических позиций.

- Простите, предложенная Вами классификация построена на различии областей исследования, предметных областей.

- Да.

- A что с методологическими подходами? Какие подходы Bbl бы выделили?

- Вы знаете, вообще-то я из тех людей, которые полагают, что методология означает правильный подбор инструмента при подходе к проблеме. Я действительно не вижу серьезных, качественных методологических различий между подходами во всех этих областях - между этнографическим или историческим подходами... Методологические различия не кажутся мне столь принципиальными, сколь предметные, теоретические различия.

- Да, но во время нашего предыдущего разговора Bы говорили с позищий институционализма, причем Ваши слова в адрес сетевого подхода звучали достаточно

\footnotetext{
${ }^{5}$ Swedberg, Richard. Economics and Sociology - Redefining Their Boundaries: Conversations with Economists and Sociologists. Princeton, NJ: Princeton University Press, 1990.
} 
критично, и подобное резкое разграничение этих подходов было даже несколько неожиданным для меня.

- Да, но я не думаю, что я вижу здесь методологические [различия]... Может быть, если взять методологию на уровне эпистемологии...

- Более инструментальном уровне?

- Да. Думаю, моя критика, ее методологическая часть, направлена именно на инструментальный уровень - того, что у вас непременно должны быть все переменные.

- Это скорее инструментальный уровень.

- Да. Так что, по крайней мере, часть моей критики касается того, что вы всегда должны быть уверены: вы зафиксировали все переменные, и если вы собираетесь исследовать отрасль промышленности, группу фирм или какие-то их взаимодействия, вы должны убедиться, что в анализ включены все формальные институциональные отношения между государством и фирмами. А также всякие неформальные вещи и вещи, связанные с культурой. И тогда вы пытаетесь понять структуру рынка. А структуры рынка - это не только связи и отношения. Это также акторы, стремящиеся сохранить существующее положение, и акторы, заинтересованные в изменениях [incumbents and challengers]. Нужно увидеть, как работает конкуренция на каком-то конкретном рынке, и то, как люди реагируют на подобное действие конкуренции; наконец, то, что поддерживает данную рыночную структуру. На мой взгляд, если вы собираетесь исследовать рынок, вам следует проанализировать все эти вещи. Вы должны учесть все переменные. Это замечание методологического характера, и такое методологическое различие действительно есть. Вы это имели в виду?

- Да. Скажите, считаете ли Вы новый институциональный подход в сочииологии особой областью исследований?

- Да. Мне кажется, новый институциональный подход нацелен на понимание действия на рынке. Это способ соединить общую политическую экономию и подход, ориентированный на изучение рынка. В целом я хотел бы ликвидировать этот разрыв между людьми, занимающимися политэкономией, и теми, кто изучает конкретный рынок. И думаю, новый институциональный подход может в этом помочь. Ведь новый институционализм утверждает значимость правил и законов, а политико-экономы верят в значимость неформальных отношений. Так что они должны согласиться с тем, что институты играют важную роль, и поверить в социальное конструирование рынков. Да, новый институционализм - это самостоятельная теоретическая традиция, которая поможет устранить этот разрыв. Я хотел бы видеть две эти части - политэкономию и исследование конкретных рынков - вместе. Потому что мне кажется, это откроет нам путь к пониманию многих вещей, в том числе таких, как глобализация, переходные периоды в нынешних постсоциалистических экономиках и др.

- Считаете ли Bы политико-экономический подход макроподходом по сравнению с исследованием конкретных рынков? Или речь идет просто о том, что он рассматривает вопросы власти, государства и т.n.?

- Думаю, политическая экономия - это скорее макроподход. Но в значительной степени он сосредоточен на государстве. Такая точка зрения коренится в политической социологии. Мой коллега Питер Эванс [Peter Evans], на мой взгляд, лучший в этой области. Да, политэкономия сосредоточена на государстве. Исследование здесь обычно начинается с государства и акторов в государстве, с попытки понять, как они регулируют тот или иной сектор экономики, - так что в целом исследование получается перевернутым с ног на голову. Вмешательство государства в экономику оказывает какое-то влияние. И задается вопрос, как следует правильно вмешиваться в экономику. В итоге развивается 
множество концепций правильного вмешательства в экономику. Думаю, в целом это макро...

И еще одна вещь в связи с институционализмом. Мне кажется, что политикоэкономический подход упускает более низкий, мезоуровень. А рынки реагируют на действия государства именно на этом уровне. Я определенно думаю, что существует процесс взаимной отдачи между строительством государства и строительством рынка. И опять-таки здесь полезна институциональная позиция - вы можете увидеть динамику этого процесса, увидеть рыночных акторов, которые пытаются что-то сделать, как-то выжить и повернуть события по-своему. Например, наша авиационная промышленность на прошлой неделе [после событий 11 сентября 2001г.]. Это во всех новостях. Руководители всех авиакомпаний Америки сидят с президентом Джорджем Бушем, и тот пытается стабилизировать ситуацию, выделив примерно 20 млрд. долларов. Думаю, это классический случай, когда все перевернуто с ног на голову. Причем это не редкость. Такое случается достаточно часто в большинстве капиталистических стран. И в этом случае у авиакомпаний есть совершенно законный аргумент, что их бизнес понес убытки, и совершенно не по их вине. Получается, что это отнюдь не погоня за прибылью, это...

- Мы называем это форс-мажсором.

- Да, да. И другая сторона вопроса заключается в том, что правительство так же признает, что транспортная система - одна из ключевых вещей. В хозяйстве много таких ключевых вещей, но, без сомнения, воздушный транспорт в Америке играет огромную роль для бизнеса. Миллионы людей, занимающихся бизнесом, летают на самолетах ежедневно. Так что вы должны следить за тем, чтобы эта система работала гладко. Наверное, это тот самый случай, дающий шанс для политико-экономического подхода, когда время от времени рыночные акторы приходят к государству и ждут от него какого-то действия. А государство при этом находится в состоянии глубокого хозяйственного кризиса и вынуждено соглашаться. Эдакий любопытный перевертыш. И неудивительно, что в ситуации крупных кризисов мы видим вещи, происходящие задом наперед, вниз головой. Например, я совершенно уверен, что далее страховые компании пойдут к правительству. И что штат Нью-Йорк уже пошел к правительству.

-Ик нему будет длинная очередь.

- Да, к правительству будет длинная очередь.

- Хорошо. А возвращаясь к экономической сочиологии в целом, какие недавно появившиеся книги или статьи показались Вам неожиданными, озадачивающчими, новаторскими, заставляющими задуматься? Если взять последние два-три-четыре года?

- Мне многие работы нравятся. Я вообще-то читаю достаточно широко, так что мне нравится многое. Думаю, написаны интересные сравнительные вещи о «капитализмах». Недавно вышла книга под редакцией Колин Крауч [Colin Crouch] и др. ${ }^{6}$ Есть интересные работы в политической науке - например, книга Дэвида Вогеля [David Vogel] о дерегуряции и ре-регуляции. ${ }^{7}$ Книга Линды Baйс [Linda Weiss] о государстве [governments], продолжающем оставаться частью способа регулирования экономики. ${ }^{8}$ Это

${ }^{6}$ Crouch, Colin, Klaus Eder, and Damian Tambini (eds.) Citizenship, Markets, and the State. Oxford; N.Y.: Oxford University Press, 2001.

${ }^{7}$ Vogel, David. Barriers or Benefits? Regulation in Transatlantic Trade. Washington, D.C.: Brookings Institution Press, 1997.

${ }^{8}$ Weiss, Linda (ed.) States in the Global Economy: Bringing Domestic Institutions Back In. N.Y.: Cambridge University Press, 2002. 
книги, написанные в русле макроподхода с позиций политической науки. Опять же, недавно вышла книга Ричарда Уитли [Richard Whitley] о системах бизнеса. ${ }^{9}$

- О разных капитализмах.

- Да, о капитализмах. Думаю, много интересных работ посвящено переходным периодам. Работы о Китае просто озадачивают. Например, если взять три книги, недавно написанные американцами (Дэвидом Уэнком [David Wank], Дагом Гатри [Doug Guthrie] и Лизой Кайстер [Lisa Keister]), - все они посвящены организации бизнеса в Китае. ${ }^{10}$ Когда читаешь эти книги, кажется, что в них рассказывается о трех разных мирах. Единственное, в чем они сходятся, - это в том, что в Китае есть сельское хозяйство и что ситуация очень нестабильна. Все зависит от того, что именно вы исследуете в Китае. И ситуация там кажется мне очень непонятной и интересной. Думаю, экономическая социология может немало почерпнуть из изучения опыта таких переходных экономик.

Мне очень нравятся Ваши статьи, нравится, чем Вы занимаетесь, - попытка увидеть изнутри проблемы, с которыми сталкивается бизнес, понять его точку зрения на эти проблемы. Мне кажется, это правильный подход. И на его основе будет легко выстроить и макроэкономический подход к проблемам переходного периода - только это будет взгляд снизу. И даже такой подход к исследованию институтов (снизу) позволяет увидеть необходимость прав собственности. Ведь то, что у вас есть закон, еще не означает, что у вас есть права собственности. И думаю, очень важно изучать эти вещи - с точки зрения рыночных акторов и с противоположной стороны. Так что переходные экономики многому нас научат.

Что касается американских статей, то мне очень нравятся работы Брайана Уци [Brian Uzzi]. ${ }^{11}$ На мой взгляд, в его работах поднимаются очень интересные вопросы о том, что за функцию выполняют сети на рынке и что за ними стоит. Он не уверен, что это

${ }^{9}$ Whitley, Richard. Divergent Capitalisms: The Social Structuring and Change of Business Systems. Oxford, N.Y.: Oxford University Press, 1999. См. также: Whitley, Richard (ed.) Competing Capitalisms: Institutions and Economies. Northampton, MA: Edward Elgar Pub., 2002.

${ }^{10}$ Wank, David L. Commodifying Communism: Business, Trust, and Politics in a Chinese City. Cambridge [England], N.Y.: Cambridge University Press, 1999.

Guthrie, Doug. Dragon in a Three-Piece Suit: The Emergence of Capitalism in China. Princeton, N.J.: Princeton University Press, 1999.

Keister, Lisa A. Chinese Business Groups: The Structure and Impact of Interfirm Relations During Economic Development. Oxford, N.Y.: Oxford University Press, 2000.

См. также: Gold, Thomas, Doug Guthrie, and David Wank (eds.) Social Networks in China: Institutions, Culture, and the Changing Nature of Guanxi. N.Y.: Cambridge University Press, 2002.

${ }^{11}$ Uzzi, Brian, Embeddedness in the Making of Financial Capital: How Social Relations and Networks Benefit Firms Seeking Financing, American Sociological Review (August 1999). Vol. 64, No. 4. P 481-505.

Uzzi, Brian. Social Structure and Competition in Interfirm Networks: The Paradox of Embeddedness, American Science Quarterly (March 1997). Vol. 42, No. 1. P. 35-68.

Uzzi, Brian. The Sources and Consequences of Embeddedness for the Economic Performance of Organizations: The Network Effect, American Sociological Review (August 1996). Vol. 61, No. 4. P. 674-699. 
определяется погоней за прибылью. Может быть, это попытка стабилизировать рыночные отношения или сделать их более эффективными. Иными словами, он пытается понять роль сетей.

Другой автор, Тоби Стюарт [Toby Stewart], работает скорее в традиции популяционной экологии [population ecology]. Но у него также есть очень интересные работы о фирмах, занимающихся высокими технологиями. Он анализирует то, почему капиталисты вкладывают сюда деньги; рассматривает перспективы выживания таких фирм. Он проделал очень интересную работу, которая заставляет задуматься над многими вещами. Стюарт получил и неожиданный результат: если проект финансируется наиболее успешными венчурными капиталистами, у него больше всего шансов выжить. И это неожиданный результат, потому что его трудно проинтерпретировать. Можно говорить о легитимности [legitimacy] и зависимости от первоначально избранного пути [раth dependency]... А можно предположить, что венчурные капиталисты просто-напросто покупают лучшие компании. И мне кажется, это один из основных вопросов экономической социологии: какова социальная структура, способствующая возникновению столь высокой степени неопределенности? Или роль социальной структуры сводится к повышению эффективности? Я думаю, работа Стюарта очень полезна в этом отношении, это очень интересный вопрос для экономической социологии.

- Мой последний вопрос: на Ваш взгляд, какие области и направления исследования будут наиболее перспективными для экономической социологии в ближайшем будущем?

- Возвращаясь назад, я считаю очень интересными исследования переходных экономик. Наверное, людям кажется, что они понимают стабильные вещи. И что они хотели бы сделать - так это пойти туда, где все находится в движении. Им кажется, что нестабильная, незавершенная ситуация может их большему научить. Так что когда они видят переходные экономики или, допустим, возникновение новых отраслей промышленности, их тянет туда. Потому что им кажется, что это дает шанс увидеть социальный процесс - то, как он возникает, нарастает, подобно набегающей волне. Я называю это старым английским словом [pressive] - это растущая волна. Людям кажется, они могут здесь многому научиться. И я тоже думаю, что это полезно, что мы многому можем научиться в таких возникающих/нарастающих ситуациях.

Хотя мне кажется, что мы при этом упускаем из виду то, как эти ситуации превращаются в более стабильные. Помните, что Вебер писал о рутинизации харизмы? Думаю, в жизни рынка происходит немало подобных вещей. Один из наиболее интересных вопросов - то, как фазы становления превращаются в более рутинные, более стабильные фазы развития. Надо попытаться теоретически выявить, как они влияют на процессы становления и стабилизации/дестабилизации на рынках. За решение этого вопроса пока никто особенно не брался. Но, несомненно, здесь имеет место особый тип социального процесса. И мне кажется, если исследователи приглядятся к нему, они поймут, что и здесь можно многому научиться.

Когда разговариваешь с людьми из мира бизнеса, они всегда рассказывают, как динамичен их бизнес, и т.д. и т.П. Думаю, в какой-то степени это действительно так. Но если взять какой-нибудь стабильный бизнес - например, производство безалкогольных напитков. Компании «Пепсико» и «Кока-Кола» - мой любимый пример. Можно поговорить с руководителями этих фирм, они будут рассказывать вам, что их компания всегда ощущает страшное давление конкуренции, что вокруг ведется настоящая война, и т.д. Но все, что происходит на американском рынке последние сорок лет, связано только с маркетингом. И вот мы в Америке сегодня покупаем продукты компании «Пепси», на следующей неделе - «Кока-Колы», и так продолжается уже сорок лет. Хотя, конечно, за это время они покупали права на все большее и большее количество товаров, которые становились продуктами компании «Пепси» или компании «Кока-Кола». 
Вот так работает рынок. Конечно, здесь есть конкуренция. Но совершенно очевидно, что это игра, уже ставшая стабильной. Это совершенно иная игра, чем та, что имеет место при возникновении рынка - например, персональных компьютеров, - когда никто не знает, что произойдет в следующий момент, с какими продуктами придется конкурировать, все непонятно. А здесь совершенно другой процесс. И размышления на эту тему могут оказаться очень полезными для нас. Если мы пытаемся изучать переходные экономики, нам следует сначала понять, что же мы видим, - открытие рынка или что-то другое. Тогда мы поймем их гораздо лучше.

Второе направление возможных исследований также связано с правилами и соглашениями. Это попытка лучше понять, при каких условиях создание закона или правил является погоней за прибылью и какие условия позволяют получить прибыль. Это одна из вещей, которыми я занимаюсь и которые кажутся мне очень интересными. Один из моментов в сравнительном изучении «капитализмов»- то, что способов организации капиталистических обществ, ведущих к экономическому росту, множество. И, вероятно, существует и множество крайностей, когда имеет место откровенная погоня за прибылью, - как в Африке, во многих частях Азии. Там есть подобный тип капитализма. Несомненно, такие ситуации есть. Но попадая в Западную Европу, США или развивающиеся [emerging] азиатские общества, оказываешься совсем в другой ситуации. И вопрос в том, существуют ли «правильные» правила и каковы они, какие правила действительно необходимы и ведут к экономическому росту.

Я думаю, в конечном итоге должно появиться целое направление нормативной экономической социологии - если экономическая социология вообще собирается кудалибо двигаться. Потому что кто-нибудь обязательно придет и спросит нас: «А какая от вас польза, ребята? Вы можете дать мне какой-то совет?» И будешь чувствовать себя неуютно, если не сможешь дать совета по поводу происходящего.

Так что второе направление исследований, которые я бы выделил, касается того, какую роль играют правила (и играют ли вообще) в создании условий для погони за прибылью. И как это вписывается в нормативный анализ. Это своего рода рубеж. Мне кажется, нормативная сторона важна уже сейчас, но она станет еще важнее. Ведь, знаете, мы всячески критикуем какие-то элементы экономической теории. А я думаю, что наша область должна не просто находить теоретические инструменты, но и создавать нормативные инструменты. А если она этого не сделает - не создаст какого-либо нормативного инструмента, - она перестанет быть особо полезной. Она должна суметь ответить на вопрос: «А зачем это?» Мы одновременно и избегаем этого, и стремимся к этому, здесь еще много работы.

- Большое спасибо.

\section{Библиография работ Нила Флигстина}

Флигстин Н. Поля, власть и социальные навыки: критический анализ новых институциональных течений // Экономическая социология, 2001. Т. 2, №4. С. 28-55 / www.ecsoc.msses.ru.

Fligstein, Neil. Stability, efficiency, and the national organization of production, in: Rauch J. (ed.) Integrating Market and Network Models of the Economy. N.Y.: Russell Sage, forthcoming.

Stone Sweet, Alec, Wayne Sandholtz and Neil Fligstein (eds.) The Institutionalization of Europe. Oxford: Oxford University Press, 2001.

Fligstein, Neil. The Architecture of Markets: An Economic Sociology of Twenty-First-Century Capitalist Societies. Princeton: Princeton University Press, 2001. 
Fligstein, N. Fields, Power, and Social Skill: A Critical Analysis of The New Institutionalisms, Экономическая социиология, 2001. Том 2, № 1. С. 4-25 // www.ecsoc.msses.ru.

Fligstein, Neil and Jason McNichol. The institutionalization of the European Union, in: A. Stone and W. Sandholtz (eds.) European Integration and Supranational Governance. Cambridge: Cambridge University Press, 1998.

Fligstein, Neil. Markets, Politics, and Globalization, in: The 1996 Uppsala Lectures in Business. Uppsala, Sweden: Uppsala University Press, 1997.

Fligstein, Neil. Social skill and institutional theory, American Behavioral Scientist (1997). Vol. 40. P. 397-405.

Fligstein, Neil. The economic sociology of the transitions from socialism, American Journal of Sociology (January 1996). Vol. 101, No. 4. P. 1074-81.

Fligstein, Neil. Markets as Politics: A Political-cultural approach to market institutions, American Sociological Review (August 1996). Vol. 61, No. 4. P. 656-673.

Fligstein, Neil and Iona Mara-Drita. How to Make a Market: Reflections on the Attempt to Create a Single Market in the European Union, American Journal of Sociology (1996). Vol. 102. P. 1-33. Reprinted in: D. Chalmers (ed.) European Union Law: Texts and Analysis. Aldershot, U.K.: Ashgate Publishing, forthcoming.

Fligstein, Neil and Haldor Byrkjeflot. The Logic of Employment Systems, in: J. Baron, D. Grusky, and D. Treiman (eds.) Social Differentiation and Social Inequality. Boulder, Colo.: Westview Press, 1996. P. 11-35.

Fligstein, Neil. Networks of power or the finance conception of control?, American Sociological Review (August 1995). Vol. 60. P. 500-503.

Fligstein, Neil and Robert Freeland. Theoretical and comparative perspectives on corporate organization, Annual Review of Sociology (1995). P. 21-43. Reprinted in: Swedberg, R. (ed.) Economic Sociology. L.: Edward Elgar Publishing, forthcoming.

Fligstein, Neil and Linda Markowitz. The Finance Conception of the Corporation and the Causes of the Financial Reorganization of Large Corporations, 1979-1989, in: Wilson, W.J. (ed.) Sociology and Social Policy. JAI Press (ASA Presidential Volume Series), 1993. P. 185206.

Fligstein, Neil and Peter Brantley. Bank Control, Owner Control, or Organizational Dynamics: Who Controls the Large Corporation?, American Journal of Sociology (1992). Vol. 98. P. 280-307.

Fligstein, Neil. The Social Construction of Efficiency, in: Zey, M. (ed.) Decision Making: Alternatives to Rational Choice Models. L.: Sage Publications, 1992. P. 72-98.

Fligstein, Neil. The Structural Transformation of American Industry: An Institutional Account of the Causes of Diversification in the Largest Firms, in: Powell, W. and P. DiMaggio (eds.) The New Institutionalism. Chicago: University of Chicago Press, 1991. P. 311-336.

Fligstein, Neil. The Transformation of Corporate Control. Cambridge, Mass.: Harvard University Press, 1990.

Fligstein, Neil. Organizational, Demographic, and Economic Determinants of the Growth Patterns of Large Firms, in: Calhoun, C. (ed.) Comparative Social Research, JAI Press, 1990. Vol. 12. P. 19-44.

Fligstein, Neil and Ken Dauber. Changes in Corporate Organization, Annual Review of Sociology (1989). Vol. 15. P. 73-96. 
Fligstein, Neil and Roberto Fernandez. Worker Power, Firm Power and the Structure of Labor Markets, Sociological Quarterly (1988). Vol. 29. P. 5-28.

Fligstein, Neil. The Intraorganizational Power Struggle: The Rise of Finance Presidents in Large Corporations, 1919-1979, American Sociological Review (1987). P. 44-58.

Fligstein, Neil. The Spread of the Multidivisional Form, 1919-79," American Sociological Review (1985). Vol. 50. P. 377-391. Reprinted in: Hall, R. (ed.) History of Management Thought. Aldershot, England: Dartmouth Publishing, 1995.

Fligstein, Neil and Roberto Fernandez. Educational Transitions of Whites and MexicanAmericans, in: Tienda, Marta and George J. Borjas (eds.) Hispanics in the U.S. economy. Orlando: Academic Press, 1985. P. 161-192.

Fligstein, Neil and Roberto Fernandez. Educational Attainment of Hispanics in the U.S., in: Cafferty, Pastora S.J. and William C. McCready (eds.) Hispanics in the United States: A New Social Agenda. New Brunswick, N.J. : Transaction Books, 1985. P. 113-146.

Fligstein, Neil and Alex Hicks. Re-evaluating the Uses of Status: The Case of Earnings Determination, Social Science Research (1984). Vol. 13. P. 90-110.

Fligstein, Neil. Going North, Migration of Blacks and Whites from the South, 1900-1950. N.Y.: Academic Press, 1981.

Fligstein, Neil and Wendy Wolf. The Impact of the Censoring Problem on Estimating Women's Occupational Attainment Equations. Madison: University of Wisconsin-Madison, 1976. 


\title{
Новые тексты
}

$\boldsymbol{V} \boldsymbol{R}$ Мы публикуем нашу статью о предмете экономической социологии, которую вполне можно назвать программной. С момента первого опубликования книги «Экономическая социология: курс лекций» в 1997 г., где этому предмету была посвящена одна из глав, утекло немало воды. И предлагаемый материал существенно развивает и упорядочивает положения, высказанные ранее в книге. До конца 2002 г. он будет опубликован в журнале «Социологические исследования».

\section{ЕЩЕ РАЗ О ПРЕДМЕТЕ ЭКОНОМИЧЕСКОЙ СОЦИОЛОГИИ}

\section{Радаев Вадим Валерьевич}

\author{
Email: radaev@hse.ru
}

Экономическая социология в России сегодня переживает период интенсивного развития. Возрастает число публикаций в ведущих социологических и экономических журналах. Созданы кафедры экономической социологии в крупных вузах, разрабатываются новые учебные курсы и развернутые образовательные программы по экономической социологии, появились первые учебные пособия. Работают исследовательские центры, активно занимающиеся экономико-социологической проблематикой. Специализированные Советы проводят защиты кандидатских и докторских диссертаций. Российская экономическая социология начала осваивать и пространство Интернета. В 2000 г. появился первый электронный журнал «Экономическая социология» (www.ecsoc.msses.ru), у которого с каждым номером становится все больше читателей. В 2002 г. открывается крупный специализированный сайт ЭКСОЦЕНТР - отбирающий и производящий экономикосоциологические ресурсы (www.ecsoc.ru). В целом наблюдается возрастающий интерес к экономико-социологическим методам в среде не только социологов, но и экономистов.

Тем не менее, в процессе опережающей формальной институционализации экономической социологии мы нередко отстаем в содержательном отношении. В нашем распоряжении слишком мало конвенциональных понятий и операциональных исследовательских схем, плохо очерчены проблемные области и основные направления экономической социологии. В значительной степени это связано с тем, что слабо освоен богатый инструментарий, накопленный зарубежными исследователями, на удивление мало переводов не только современных, но и классических работ ${ }^{1}$. В результате часто приходится слышать один и тот же вопрос: «Мы понимаем, что экономическая социология - важное и интересное направление. Но в чем все-таки состоит ее предмет? Это, видимо, некое сочетание экономической теории и социологии?»

В данной работе мы постараемся развить изложенные нами ранее представления об исходном определении предмета экономической социологии в еe современном

1 Подробнее о состоянии и проблемах современной российской экономической социологии см.: Радаев B.B. Экономическая социология: современное состояние и перспективы развития / Ядов В.А. (отв. ред.) Социология в России. 2-е дополн. изд. М.: Институт социологии РАН, 1998. С. 253-263. См. также: Веселов Ю.В. Экономическая история в России: история и современность // Журнал социологии и социальной антропологии, 1999. Том 2. № 2. С. 63-70; Якубович В., Ярошенко С. Экономическая социология в России // Экономическая социология, 2001. Том 2, № 2. С. 140-145 // www.ecsoc.msses.ru 
понимании 2 . И поскольку мы весьма скептически относимся к общим рассуждениям о междисциплинарности, начнем с попытки прояснения характера междисциплинарных границ.

\section{Где пролегают междисциплинарные границы?}

Итак, где же провести границы между экономической теорией и экономической социологией? Быть может, различен объект исследования? Отчасти это верно. Экономическая теория в значительно большей степени изучает отношения, овеществленные в потоках материальных, финансовых, информационных ресурсов, готовой продукции и услуг. Социология же более ориентирована непосредственно на человеческое поведение и социальные связи как таковые. Но с разделением объектных областей возникают явные сложности. Попробуйте определить, что такое «экономика» (как предположительный объект экономической теории) и чем «экономическое» отличается от «неэкономического». Сразу выяснится, что границы объектов исследования разных дисциплин крайне условны и размыты, они не закреплены жестко за этими дисциплинами. Монополистические притязания на исследование тех или иных объектов (в частности, хозяйственных отношений) сегодня выглядят все менее обоснованными. И все чаще экономисты и социологи обращаются к изучению одних и тех же объектов, играют на одном проблемном поле.

Может быть, главное отличие коренится в методах сбора и анализа данных, применяемых экономической теорией и экономической социологией? И такие различия имеются. Экономисты в большей степени стремятся к улучшению предсказательных возможностей своих моделей, облачая их в строгие математические формы. Они могут вовсе не обращаться к эмпирическому материалу. Социологи же, как правило, делают упор на дескриптивный (описательный) анализ. Их модели менее строги в формальном отношении, но чаще подвергаются проверке на конкретных эмпирических данных. Однако мы не думаем, что следует далеко заходить в подобных противопоставлениях, представляя дело так, будто экономисты оперируют «чистыми моделями», а социологи «роются в эмпирике». Ведь среди экономистов есть немало скрупулезных эмпириков, а многие социологи смотрят на землю с высоты «птичьего полета».

Есть различия и в характере используемых данных. Экономисты чаще прибегают к готовым агрегированным показателям национальной статистики. А социологи в большей степени опираются на выборочные данные, которые черпаются из специально организованных под проект источников. Главным среди социологических методов сбора данных считаются анкетные опросы (социолога даже нередко представляют как «человека с анкетой»). Вдобавок социологи демонстрируют большее, по сравнению с экономистами, разнообразие методов сбора данных, среди которых также включенное наблюдение, углубленные интервью, фокус-группы. Но, заметим, все эти пути экономистам отнюдь не заказаны. Конечно, экономисты реже прибегают к опросным методам и менее искушены в технике опросов. Однако многие из них сегодня все активнее привлекают опросные данные (особенно это характерно для России с хроническими слабостями ее официальной статистики, где специальный опрос часто оказывается единственным источником необходимых данных). В свою очередь, многие социологи не чураются статистической информации. Таким образом, несмотря на традиционно сложившиеся различия применяемых методов, все-таки не здесь следует искать основной междисциплинарный водораздел. Разница в техниках сбора и анализа данных второстепенна.

${ }^{2}$ Более раннюю версию см.: Радаев В.В. Экономическая социология: курс лекций. М.: Аспект Пресс, 1997. Глава 3. 
Принципиальный вывод состоит в том, что наиболее глубокое и существенное различие между экономической теорией и экономической социологией состоит в общеметодологических предпосылках анализа, в подходах к моделированию человеческого действия, проистекающих из разнородных оснований. Эти дисциплины различаются не тем, что они изучают (подобных различий становится все меньше), а тем, как они это делают. Они ставят перед собой разные типы задач. Изучать экономику или социологию не значит выбирать между анализом экономических и социальных отношений. Это значит овладевать соответствующим подходом, который в принципе может быть применим к объектам самого разного рода.

Таким образом, говоря об экономической социологии, мы в дальнейшем будем иметь в виду особый подход, противостоящий экономическому подходу даже в случаях совпадения исследовательского объекта и методов сбора данных. В наиболее общем виде это означает использование основных конщепций $u$ аналитических инструментов соииологии для анализа хозяйственньх отношений. С этим положением, видимо, все согласны, но само по себе оно мало что объясняет.

В чем же состоит специфика социологического подхода? Экономисты берутся за объяснение весьма сложных материй (формирование цен, движение финансовых потоков и т.п.), которые для обывателя остаются тайной за семью печатями, и в итоге сводят их объяснение к логике здравого смысла, к способам поведения обычных «средних» людей. Что же касается социологии, то трудно избавиться от впечатления, что она, напротив, занимается очень «простыми» вещами, над которыми мы обычно не даем себе труда задумываться, воспринимая их на уровне здравого смысла. Можно сказать, что интенции двух дисциплин прямо противоположны: экономическая теория производит редукцию к обыденному, а экономическая социология - проблематизаџию обыденного. Различие интенций связано, в том числе, с тем, что экономическая теория видит своей основной задачей предсказание, и эта прогностическая нацеленность заставляет укорачивать список анализируемых переменных и упрощать связи между ними. А экономическая социология значительно больше тяготеет к описанию, и ее дескриптивные наклонности побуждают искать все новые точки соприкосновения с реальностью и проблематизировать наблюдаемые явления.

Экономическая теория тяготеет к соединению двух пониманий «естественного». Первое трактует его как нечто простое, привычное и повседневное. А за ним скрывается второе, более фундаментальное понимание «естественного» - того, что соответствует «природному состоянию» человека, его врожденным склонностям и инстинктам ${ }^{3}$. Так возникают универсальные психофизиологические и абстрактно морализаторские истолкования. В частности, на вопрос, почему возникают трудовые конфликты, можно ответить: потому, что в природе человека заложено подсознательное агрессивное начало. Или почему, скажем, люди работают спустя рукава, даже если это грозит им явными материальными потерями? Опять же есть объяснение: потому что человек по натуре ленив и испорчен.

Экономическую социологию влечет «естественность», понимаемая как простота, повседневность, но она использует ее как материал для проблематизации. Действительно, ведь самые привычные вещи только кажутся «простыми» или «естественными». В самом деле, как ответить на следующие «простые» вопросы: почему потребители ходят в разные магазины и платят за одну и ту же вещь совершенно разные цены? Почему предприниматели стараются выбирать деловых партнеров из строго определенного круга? Почему работники ревниво реагируют даже на ничтожное повышение оплаты своих

${ }^{3}$ Напомним известную фразу Адама Смита, который приписывал человеческой природе «склонность к мене, торговле, к обмену одного предмета на другой» [Cмuт $A$. Исследование о природе и причинах богатства народов. М.: Соцэкгиз, 1935. Т. 1. С. 16]. 
коллег, но спокойно воспринимают большие разрывы в доходах между «рядовыми» и «начальством»? Многое из того, что мы сегодня считаем привычным, обыденным, возникло совсем недавно. А то, что длилось столетиями, сегодня трещит по швам. Долгое время, например, существовало достаточно жесткое разделение хозяйственных ролей в домашнем хозяйстве между мужчиной и женщиной, и оно считалось «естественным». А потом «вдруг» роли начали интенсивно перемешиваться. Куда же девалась «естественность»?

И что даже более важно: социология не занимается тем, что называют «человеческой натурой». Она старается избегать «естественности», понимаемой как совокупность универсальных, изначально заданных свойств человека. Да и можем ли мы говорить об универсальности, когда сплошь и рядом отдельные люди и группы людей, оказавшись в сходных ситуациях, демонстрируют устойчивые различия в своем поведении? С точки зрения экономической социологии фигура человека, принимающего независимые рациональные решения, исторична и предполагает наличие гражданской свободы и элементарных прав частной собственности на ресурсы. Таким образом, рационализм и эгоизм в той же мере являются продуктом окружающих человека сложных социальных условий, не сводимых к его «природе» или «здравому смыслу». Причем сами эти условия не остаются неизменными. Они постоянно воспроизводятся и трансформируются как результат социальных взаимодействий.

\section{Как определить предмет экономической социологии?}

Попробуем теперь дать исходную формулировку предмета экономической социологии. Мы определяем его в духе М. Вебера: экономическая социология изучает экономическое действие как форму социального действия ${ }^{4}$. «Экономическое действие» представляет собой осуществление контроля над ограниченными ресурсами ненасильственными методами в целях удовлетворения своих потребностей. А «социиальное действие» - это форма деятельности, которая, во-первых, содержит в себе внутреннее субъективное смысловое единство; во-вторых, по этому смыслу соотносится с действиями других людей и ориентируется на эти действия. Иными словами, с социальным действием мы имеем дело тогда (и только тогда), когда оно внутренне мотивировано, а его субъект ожидает от других людей определенной ответной реакции ${ }^{5}$. Социальное действие в данной трактовке выступает основанием и одновременно внутренним элементом экономического действия.

Раскрытие предмета экономической социологии через веберовские категории экономического и социального действия определяет этот предмет с позиций методологического индивидуализма. И важно сразу же оговориться, что последний резко отличается от методологического индивидуализма, принятого в экономической теории. Индивидуализм homo economicus непосредственно сопряжен с его автономностью, с относительной независимостью принимаемых решений и установлением опосредованной социальной связи - преимущественно через соотнесение результатов действия. Социологический индивидуализм - явление другого методологического порядка. Индивид рассматривается здесь в совокупности своих социальных связей и включенности в разнородные социальные структуры. Общество в данном случае не просто витает как абстрактная предпосылка, но зримо присутствует в ткани индивидуального действия.

4 Наше определение предмета экономической социологии не является единственно возможным. Марксистская, структурно-функционалистская или феноменологическая традиции вправе претендовать на свои особые формулировки.

${ }^{5}$ См.: Вебер М. Основные социологические понятия / Вебер М. Избранные произведения. М.: Прогресс, 1990. С. 602-603, 625-626. 
Всякий социологический индивидуализм, таким образом, в сильной степени относителен. И веберовский подход правомерно называть индивидуализмом в противовес, скажем, холизму Э. Дюркгейма. На фоне же учений экономистов-неоклассиков такое определение оказывается очень условным.

В новой экономической социологии специфика экономсоциологического подхода определяется тремя связанными положениями.

1. Экономическое действие есть форма социального действия.

2. Экономическое действие укоренено в социальных структурах.

3. Хозяйственные институты являются социальными конструкциями ${ }^{6}$.

О первом положении мы уже говорили. Оно означает, во-первых, что экономическую социологию интересует не только наблюдаемое поведение, но и субъективная позиция хозяйственного агента - его мотивы, определения ситуации, вырабатываемые людьми концепџии контроля [conceptions of control] - совокупность значений и смыслов, позволяющих интерпретировать происходящее и объяснять свои собственные поступки. А во-вторых, это значит, что мотивы хозяйственного агента выходят за пределы сугубо экономических целей. И принципиальными источниками хозяйственной мотивации, наряду с экономическим интересом, выступают социальные нормы и принуждение ${ }^{7}$

Подобное понимание означает включение экономического действия в социальные контексты и признание его социальной укорененности (встроенности) [embeddedness of economic action]. Экономическое действие предполагает существование отношений повторяющихся и предсказуемых связей между хозяйственными агентами, - среди которых важную роль играют культурные и властные отношения. Далее, люди вступают в эти отношения не с чистого листа, им предпосланы институциональные устройства [institutional arrangements] в виде общезначимых норм и правил, регулирующих хозяйственные взаимодействия. И любой рыночный контракт предусматривает наличие таких правил, реализующих властные зависимости и несущих на себе следы культурных контекстов. Кроме этого, действия хозяйственных агентов во многом определяются существованием различных социальных структур. К их основным типам относятся:

• сети межиндивидуального взаимодействия;

- организационные структуры;

• социальные группы;

• локальные и национальные сообщества.

Таким образом, экономическое действие институционально оформлено и осуществляется в рамках институциональных ограничений, а способы действия являются продуктом функционирования социальных структур, а не предпочтений изолированного индивида. При этом степень и способы укорененности экономических действий в разных сообществах могут быть принципиально различны, они определяются сложными констелляциями факторов экономического, технологического, политического и культурного свойства.

Наконец, хозяйственные институты рассматриваются как сощиальныле конструкиии. Институты и структуры не только выступают как нечто предзаданное действиям человека, ограничивающее и стимулирующее эти действия. Они сами выступают как конфигурации

\footnotetext{
${ }^{6}$ Granovetter, M., Swedberg, R. (eds.) Introduction to the Second Edition, in: Granovetter, M., Swedberg, R. The Sociology of Economic Life. Boulder, Col.: Westview Press, 2001. P. 8.

${ }^{7}$ Более подробно см.: Радаев В.В. Экономическая социология: курс лекций. Глава 4.
} 
систем действия, конструируются акторами, способными к мобилизации ресурсов и преодолению исторически сложившихся ограничений.

Задача экономической социологии, таким образом, не ограничивается разработкой собственно теории действия. А определение предмета экономической социологии через теорию социального действия, разумеется, не означает, что ее исследования ограничиваются микроуровнем. Речь идет лишь о выборе исходной точки, с которой начинается аналитическое движение, - от действия человека к отношениям между людьми, далее к формированию институтов и структур, оформляющих и стимулирующих социальные действия. Совокупности институтов и структур формируют локальные порядки, а взаимосвязи последних, в свою очередь, открывают путь к анализу порядков на макроуровне. Добавим, что именно это «восхождение» и эти переходы в методологическом отношении всегда составляли основную трудность для социальных наук $^{8}$.

\section{Как построить модель экономико-социологического человека?}

Существует модель экономического человека, которая, несмотря на многочисленные вариации в экономических подходах, может быть представлена в виде ограниченного числа достаточно четких предпосылок. Нам представляется, что таких исходных предпосылок четыре.

- Человек независимый. Это автономный, атомизированный индивид, принимающий самостоятельные решения исходя из своих личных предпочтений.

- Человек эгоистичный. Он в первую очередь заботится о своем интересе и стремится к максимизации собственной выгоды.

- Человек рациональный. Он последовательно стремится к поставленной цели и рассчитывает сравнительные издержки того или иного выбора средств ее достижения.

- Человек информированный. Он не только хорошо знает собственные потребности, но и обладает достаточной информацией о средствах их удовлетворения 9 .

Возникает вопрос: а какие принципы могут быть заложены в основу построения социологической модели экономического действия? Нужно сказать, что в экономической социологии (и в социологии в целом) это сделать значительно труднее, ибо здесь царствует методологический плюрализм, граничащий с эклектикой ${ }^{10}$.

Поскольку социологи испытывали явные затруднения с формулированием подобных принципов, экономисты сами предложили решение, наиболее удобное для себя. Исходной точкой в этом случае стала позиция В. Парето, который разделил экономическую теорию и социологию, предложив первой заниматься изучением «логических действий», а второй - «логическим исследованием нелогических действий» ${ }^{11}$. П. Самуэльсон придал

${ }^{8}$ Coleman, J. Social Theory, Social Research and the Theory of Action, American Journal of Sociology (1986). Vol. 91. P. 1320-1327.

${ }^{9}$ См.: Радаев В.В. Экономическая социология: курс лекций. Глава 1.

${ }^{10}$ Для стороннего взгляда экономиста картина выглядит следующим образом: «С тех пор, как функционализм и марксизм утратили свое временное господство, социология подверглась дезинтеграции, по крайней мере на уровне теории, превратившись в аморфную массу многочисленных направлений при отсутствии каких-либо намеков на последующее воссоединение» (Vanberg, V.J. Rules and Choice in Economics. L.: Routledge, 1994. P. 11).

${ }^{11}$ См.: Арон Р. Этапы развития социологической мысли. М.: Прогресс, 1993. С. 408. 
этому различию канонический характер. А закреплено оно в остроумном афоризме экономиста Дж. Дьюзенберри: «Вся экономическая теория посвящена тому, как люди делают выбор; а вся социология посвящена тому, почему люди не имеют никакого выбора» ${ }^{12}$.

Как при таком подходе выглядит «социологический человек»? Первый способ реконструкции его поведения - построение по методу от противного. Иными словами, его рассматривают как полного антипода homo economicus. Если последний, скажем, - это человек независимый, эгоистичный, рациональный и компетентный, то homo sociologicus оказывается человеком, который подчиняется общественным нормам и альтруистичен, ведет себя иррационально и непоследовательно, слабо информирован и не способен к калькуляции выгод и издержек ${ }^{13}$. Посмотрим пример подобного сопоставления двух моделей. Вариант homo economicus представлен экономистами К. Бруннером и У. Меклингом: это «человек изобретательный, оценивающий, максимизирующий полезность» (Resourceful, Evaluating, Maximizing Man, или модель REMM) ${ }^{14}$. А «социологический человек» описывается моделью, предложенной С. Линденбергом: это «человек социализированный, исполняющий роли, поведение которого санкционировано обществом» (Socialized, Role-Playing, Sanctioned Man, или модель SRSM) ${ }^{15}$.

Помимо упомянутого принципа «от противного» можно строить модель экономикосоциологического человека по принципу «подобия» homo economicus или имитации этой модели (что, кстати, тоже вполне устроило бы экономистов). Например, можно применить маржиналистский подход, но сменить состав переменных и представить homo sociologicus как максимизатора степени собственной социализации и минимизатора неопределенности, связанной с его неполной включенностью в социальные нормы. Избрав принцип «от противного» или построение «по подобию», остается формализовать социологическую модель, чтобы придать ей более рабочий вид. Довести такую модель до количественной определенности, конечно, непросто. Но в случае успеха у экономической модели появится родственная конструкция, обрастающая собственным математическим аппаратом. В итоге наряду с «экономическим автоматом» мы получим еще один «социологический автомат», причем более диковинный и, пожалуй, менее привлекательный - туповатый и пассивный. Не мудрено, что возникает соблазн отсечь социологический полюс и использовать экономический подход для решения любых, в том числе социальных, проблем (например, К. Бруннер уверен, что «модель REMM

12 См.: Duesenberry J. Comment on «Economic Analysis of Fertility», Demographic and Economic Change in Developed Countries / Ed. by the Universities-National Bureau Committee for Economic Research. Princeton: Princeton University Press, 1960. P. 233.

12 При рассмотрении homo sociologicus в качестве репрезентанта социологического подхода явно или неявно заимствуются утрированные версии структурного функционализма, представляющие образ «пересоциализированного» индивида.

14 См.: Бруннер $K$. Представление о человеке и концепция социума: два подхода к пониманию общества // Thesis, 1993. Т. 1. Вып. 3. С. 55-58. У. Меклинг добавлял еще две характеристики: «человек, действующий в условиях ограничений (Restricted)» и «человек ожидающий (Expecting)» (модель RREEMM).

15 Для эмпирической социологии С. Линденберг вводит еще одну модель: «человек, имеющий собственное мнение, восприимчивый, действующий» (Opinionated, Sensitive, Acting Man, или модель OSAM) (Lindenberg S. An Assessment of the New Political Economy: Its Potential for the Social Sciences and for Sociology in Particular, Sociological Theory (Spring 1985). P. 99-113). 
обеспечивает единый подход для социальных наук») ${ }^{16}$. Социологический человек оказывается ненужным.

Нетрудно понять, что социологов подобные модели пересоциализированного человека [oversocialized man] (Д. Ронг), подчиняющегося «чужой» логике, никак не могут устроить. Каковы возможные альтернативы? Бросаться в другую крайность и придумывать нечто, совершенно не связанное с экономическим подходом, - для экономической социологии тоже вариант нежелательный. Поэтому представим модель homo economicus и описываемую экономистами модель «пересоциализированного» homo sociologicus в качестве крайних точек, определяющих некую общую ось, и зададимся вопросом, возможен ли синтез этих «полярных» моделей. И, следовательно, вправе ли мы надеяться на появление некоего особого «экономико-социологического человека»? Здесь возникает еще несколько вариантов логических действий.

Первый, наиболее простой способ их возможного синтеза - суммирование приписываемых человеку противоположных качеств (в той или иной комбинации). Человек в этом случае оказывается одновременно рациональным и нерациональным, эгоистичным и альтруистичным, компетентным и неинформированным. Впрочем, подобное механическое сложение путем «схлопывания» полюсов хорошо для «диалектических игр», но порождает непреодолимые трудности для последующей операционализации понятий и эмпирической работы.

Второй, более тонкий логический ход, - методом взаимного сближения и уступок найти компромиссную точку на оси между двумя полюсами, своего рода «золотую середину». Именно эта точка в данном случае и должна указать адрес «экономико-социологического человека», обретающего в силу своего промежуточного положения некие дополнительные качества (например, возможность не просто принимать волевые решения или безвольно следовать сложившимся нормам, а согласовывать свои действия с действиями других $)^{17}$. Действительно, попытки методологической рефлексии невольно влекут экономистов и социологов к такому сближению. Тем не менее, мы не считаем этот путь особенно перспективным, ибо сама проблема, на наш взгляд, должна быть поставлена иначе.

Как и большинство социологов, мы не склонны раскрывать объятия навстречу пересоциализированному антиподу «экономического человека». И потому исходим из предположения, что экономико-социологический человек не застывает в крайней позиции и не закреплен в одной из промежуточных точек. Он перемещается («плавает») в континууме между двумя указанными полюсами. Но если социология ищет человека не в какой-то отдельной точке, а на протяжении всего континуума, то это означает, что он может быть представлен лишь в виде целой галереи фигур, как описание различных типов действия. Экономическая социология не ищет одного универсального способа объяснения, но строит различные типологии. В этом смысле, в отличие от hото economicus, экономико-сочииологический подход характеризуется не одной фиксированной

${ }^{16}$ См.: Бруннер К. Указ. соч. С. 71.

17 «Экономический анализ, основанный на фигуре homo economicus, и социологический анализ, который исходит из существования homo sociologicus, действительно являются двумя противоположными точками зрения. В то время как первая сводит все социальные явления к действиям как бы изолированных индивидов и не учитывает других социальных взаимосвязей, вторая объясняет индивидуальные действия давлением социальной взаимозависимости, не допуская, что последняя, в свою очередь, возникает из общения между отдельными людьми. Почему бы не изобразить человеческий тип, охватывающий оба этих крайних типа в качестве специальных случаев, как например, homo socioeconomicus?» (Вайзе П. Homo economicus и homo sociologicus: монстры социальных наук // Thesis, 1993. Т. 1. Вып. 3. С. 121). 
моделью, но является программой построения разных моделей, описывающих широкий спектр типов действия в континууме между полюсами «недосоииализированного» $u$ «nересочиализированного» действия. Модель «экономического человека» в этом случае не отбрасывается, а включается в методологический арсенал в качестве одной из ключевых рабочих моделей для типологических построений, но при этом рассматривается не как единственная или господствующая, но скорее как крайний случай.

Что характерно для экономико-социологического человека в предлагаемой нами схеме? Во-первых, человек занимает здесь более активную и более деятельную позицию. Это человек не просто информированный, но познающий (knowledgeable agent); не просто следующий нормам, но социализирующийся; не просто субординированный, но борющийся. Это человек, который способен стать актором, рефлексирующим собственные действия. Он уже не просто занимает отведенные ему структурные позиции, проигрывает заранее предписанные роли, подчиняется установленным нормам, становится объектом чьих-то санкций. Действуя в рамках многих ограничений, человек, как предполагается, сам простраивает свой мир и вырабатывает значения происходящего, он демонстрирует способность к самостоятельному действию, а во многих случаях и к рефлексии по поводу этого действия.

Во-вторых, превращение человека в актора в экономико-социологическом смысле означает, что он в состоянии не только выбирать разные способы использования дефицитных ресурсов, но способен переключаться (спонтанно или в результате волевых усилий), переходя от логики экономически ориентированного к логике социально ориентированного действия и обратно. Он может переключать режимы действия, актуализируя тот или иной сетевой контур своих взаимосвязей, перемещаться между разными смысловыми полями, меняя способы ранжирования и порядок обоснования ценности ресурсов [order of worth] (Л.Тевено).

В-третьих, экономическая социология предполагает, что помимо активного выбора и возможности переключения режимов действия и оценивания человек способен поступать вопреки [to do otherwise] (Э.Гидденс) - в том числе, вопреки очевидной рациональности или устоявшимся нормам. Он не просто бросается за выгодой (тем более сиюминутной) и не идет непременно по пути наименьшего сопротивления. Экономико-социологический человек в состоянии проявить волевые усилия и преодолевать сопротивление обстоятельств. (В качестве таких обстоятельств могут выступать дефицит ресурсов, неадекватность существующих правил поведения, неясность целей и многое другое.)

Наконец, в-четвертых, человек способен к дифференцированным действиям. Причем, дело не в том, что он может в одних случаях вести себя рационально, независимо или эгоистично, а в других — проявлять альтруизм или следовать традиционным нормам. И не только в том, что рамки совершаемых им действий более широки, нежели это предусмотрено экономической теорией, а в том, что их различия социально обусловлены, а сами действия укоренены в социальных структурах, в которые включен данный хозяйственный агент.

Итак, суммируем предпосылки, которые должны быть заложены в основу построения моделей экономико-социологического действия (еще раз оговоримся, что они не «симметричны» предпосылкам модели «экономического человека»). Перед нами предстает:

- человек рефлексирующий - способный на активный и осознанный выбор;

- человек гибкий - способный переключаться между разными режимами действия;

- человек волевой - способный поступать вопреки обстоятельствам и избранным ранее способам действия; 
- человек социально-дифференциированный - осуществляющий разные, социально обусловленные способы действия, привязанные к различным социальным структурам и институтам.

В результате перед экономической социологией встают как минимум три методологические задачи. Первая - построение, вместо единой модели, набора типологий по ряду шкал, которые связывают (и одновременно противопоставляют) экономически и социально ориентированные действия, а также дифференцируют эти действия по социальным общностям ${ }^{18}$.

Вторая методологическая задача экономической социологии заключается в определении и раскрытии социальных и экономических условий, при которых осуществляется переключение - взаимопереход экономически и сощиально ориентированных действий. Например, что побуждает предпринимателя, зарабатывающего деньги любыми доступными и недоступными способами, впоследствии перечислять их на нужды детского дома? Или почему работник, которого все считали «душой коллектива», преступает всякие нормы приличия при дележе дефицитного блага (премии, более высокой должности)?

Третья методологическая задача - определить, при каких условиях человек превращается в подлинного актора, способного к реализации собственных стратегий.

\section{Что понимать под стратегией действия?}

Необходимо еще раз вернуться к исходной точке нашего движения - понятию социального действия, - чтобы попытаться растянуть сосредоточенное в нем смысловое пространство. С одной стороны будут находиться практики действия. Они понимаются нами в расширительном смысле - как отдельные более или менее связанные акты рутинного повседневного действия. С другой стороны зафиксируем то, что будет называться стратегиями действия, которые первоначально определяются как схемы действия, в противоположность практикам как отдельным деятельностным актам ${ }^{19}$. На стратегиях мы далее и сосредоточим внимание.

С точки зрения экономического подхода стратегия выступает как устойчивый последовательный выбор способов действия на пути к достижению фиксированной иели в условиях ограниченного набора ресурсов. Например, в теории игр, противопоставляющей играм случая стратегические игры ${ }^{20}$, стратегия человека определяется попросту как выбор наилучшего способа действия, исходя из поведения других агентов ${ }^{21}$. Иными словами, в

18 Примеры подобных типологий в анализе хозяйственной мотивации см.: Рaдаев $B$. Внеэкономические мотивы предпринимательской деятельности (по материалам эмпирических исследований) // Вопросы экономики, 1994. № 7. С. 85-97; Радаев В.В. Что означает «принять предпринимательское решение» (По результатам опроса предпринимателей) // Общественные науки и современность, 1995. № 1. С. 33-39; Радаев B.B. О наличии сбережений и сберегательных мотивах российского населения // Вопросы социологии, 1998. Вып. 8. С. 39-54.

19 Речь идет не о понятии «фоновых практик» из арсенала социологии повседневности. И вообще оба термина (стратегии и практики) употребляются нами в достаточно широком смысле и определяются относительно друг друга.

${ }^{20}$ Schelling, T. The Strategy of Conflict. Cambridge: Harvard University Press, 1960. P. 3, 9-10.

${ }^{21}$ Наличие субъективной рациональности и соотнесение решений с действиями других агентов в теории игр напоминает веберовское определение социального действия. Однако здесь оно сводится к упрощенной схеме, где человек принимает автономные 
экономическом смысле мы имеем стратегию, когда обнаруживаем устойчиво повторяющееся целерациональное поведение. В этом смысле все поведение hото economicus, рассматриваемого в качестве «нормального», среднего человека, по сути, является реализацией каких-то стратегий. Поэтому в экономической теории различие между практиками и стратегиями не существенно.

Экономическая теория привлекает внимание к проблемам, которые не должны оставлять равнодушным и социолога. Это проблемы:

- индивидуального выбора способов действия;

- устойчивости этого выбора;

- риска и неопределенности, сопряженных с выбором;

- мобилизации ограниченных ресурсов для обеспечения устойчивого выбора.

Однако у социологов понимание стратегии должно дополняться как минимум еще одним существенным элементом. Под стратегией понимается устойчивая совокупность осмысленных, рефлексивных действий. Социолог не может отбросить субъективный элемент, связанный с внутренним смыслом действия. Целесообразно также провести различие между стратегией и тем, что выше было названо практиками. В социологическом определении стратегия предполагает:

- осуществление некоего выбора в противовес простому следованию правилу;

- наличие определенной длительности действий в противовес их ситуативности;

- наличие мотивированного, а не контекстуального действия;

- существование элементов планирования будущих действий в противовес чисто реактивному действию;

- наличие рефлексии по поводу совершаемых действий.

Последний пункт требует пояснения. От обычных практик стратегическое действие отличается тем, что человек осознает причины и характер собственных действий, способен совершить их разбор, по крайней мере, после завершения действия. При этом сама стратегия часто не осознается им в полном объеме. Однако стратегическое действие должно содержать, как минимум, элемент потенциальной рефлексивности. То есть предполагается, что последовательность действий (пусть даже неосознанная в полной мере) может быть относительно легко выявлена, например, при обращении к человеку как респонденту в ходе социологического опроса.

Далее, стратегия не предполагает полуавтоматическое следование одной, первоначально выбранной схеме, она предусматривает определенную гибкость - способность переключения с одной схемы действия на другую. Стратегии также часто связаны с преодолением обстоятельств и сопротивления среды, действием вопреки, нежели с «действием по».

Используя экономическую терминологию, можно определить понятие стратегии как проявление субъективной рачиональности, связанной с упорядочиванием предпочтений, устойчивым распределением ресурсов и организацией собственного будущзего. Например, если человек ежемесячно упрямо откладывает в качестве сбережений четверть текущего дохода, то он не просто устойчиво распределяет ресурсы, но определенным образом

решения, не обсуждая их с другими агентами. Из соотнесения действий исключаются также более широкие институциональные контексты, как это предполагается в позиции М. Вебера. 
простраивает свое будущее. И речь идет уже не об отдельном акте рационального действия, а о некой длительной, повторяющейся связи подобных актов.

Что способно придавать актам повседневного выбора относительную устойчивость? Наличие высоких целей и ценностей или стремление к некоему идеальному состоянию? Такого рода трактовки модельного действия весьма популярны. Оно предполагает, что хозяйственный агент до начала действий вырабатывает видение конечной идеальной ситуации и начинает двигаться к ней (с неизбежными отклонениями и ошибками). В нашем понимании у человека вовсе не обязательно должна быть модель той идеальной ситуации, которой он хотел бы достичь. И дело не в том, что этот идеал трудно выработать, а в том, что в повседневной деятельности человек и не пытается это сделать. Стратегическое действие реализуется иначе - как совокупность действий, связанных с решением совершенно конкретных практических вопросов. Здесь нет прямолинейного движения к заранее заданной конечной цели. Задается не конечное состояние, которого необходимо достичь по завершении целенаправленных действий, а траектория первоначального движения. Определяется вектор, направление которого может и должно подвергаться корректировке по мере продвижения вперед. Большинство людей не в состоянии просчитать свои действия на сорок ходов вперед, к тому же во многих ситуациях это и не целесообразно (слишком много привходящих факторов могут изменить ситуацию). Достаточно в каждый момент знать, как сделать следующие два-три хода. Причем переопределение ситуации может побудить к изменению направления движения.

Далее возникает вопрос о том, из чего же исходит человек, вырабатывая эти ближайшие ориентиры? Его решения опираются на то, что мы называем принципами действия [guiding principles of action]. Эти принципы, с одной стороны, не сводятся к сиюминутным мотивам, связанным с актами повседневного рутинного выбора, а с другой стороны, не возносятся до уровня высоких ценностей и отвлеченных идеальных стандартов. Они представляют собой конкретные практические императивы, привязанные к повседневной жизни человека, к области его (ее) практической компетенции ${ }^{22}$. К числу подобных принципов относятся, например, такие императивы, как: «нужно иметь деньги на черный день», или «нужно заниматься своим профессиональным делом», или «лучше не давать деньги в долг» ${ }^{23}$. Повседневные выборы осуществляются на фоне подобных принципов, которые, в свою очередь, могут выражаться в самых разных мотивах: следовании экономическому интересу, отношении к ценностям, потворствовании привычкам. Комбинация этих принципов и формирует то, что можно назвать стратегиями, или схемами действия, которые воспроизводятся в повседневном выборе. Добавим, что стратегические действия строятся не по одной глобальной схеме, а сразу по нескольким схемам, относящимся к разным видам деятельности человека, - трудовой, потребительской, сберегательной и т.п.

Следует далее разделить два вида стратегических действий - стратегию повседневных действий (о которой шла речь выше) и стратегический выбор. Последний связан с

22 На операциональном уровне эти принципы не имеют ничего общего, скажем, с ориентацией на «поддержку реформ» или с «отношением к частной собственности», которые столь часто становились предметом российских социологических опросов. Вопросы о высоких ценностях и идеологических схемах имеют, на наш взгляд, невысокую ценность, в то время как о принципах действия вполне допустимо спрашивать обычных людей, не выставляя их в квази-экспертную позицию.

${ }^{23} \mathrm{C}$ этой точки зрения экономический императив максимизации полезности слишком абстрактен, чтобы быть принципом действия, он, скорее, вменяется обычному человеку. Но он может быть конкретизирован и представлен в виде ряда осмысленных принципов действия. 
выбором не просто способов поведения, а самих принципов действия (например, продолжать ли образование, платить ли налоги, уезжать ли за границу на длительное или постоянное проживание). Это выбор, который определяет совокупность практических действий на достаточно длительную перспективу и приводит к реконфигурации практик деятельности человека или группы. Понятно, что такого рода стратегический выбор совершается относительно редко, но имеет принципиально важное значение.

Кто является субъектом стратегического действия? Является ли оно достоянием представителей элитных групп или особой породы людей (например, так называемых «прирожденных предпринимателей»)? Существуют концепции, в рамках которых стратегии вообще не являются атрибутами индивидуального действия. Так, например, в соответствии с позицией М. Де Серто, субъектом стратегии могут выступать государство, армия, хозяйственное предприятие, город, т.е. институты, обладающие достаточной властью, чтобы ограничить и разметить некое пространство (физическое и смысловое) как свое собственное. Отдельный же человек в этой трактовке не имеет собственного места, он движется по непредопределенной траектории внутри чужого пространства, принадлежащего другим и размеченного другими. Самое большее, на что он способен, это тактические маневры, манипулирование ресурсами на чужой территории и под надзором «противника» (политической власти, собственника). За ним сохраняется возможность мелких захватов, но удержать захваченное человеку уже не дано ${ }^{24}$.

Мы придерживаемся иной точки зрения, в соответствии с которой стратегическое действие в принципе доступно каждому, но реально осуществляется далеко не всегда. Иными словами экономико-социологический человек способен на стратегию. А условия ее возникновения должны стать предметом специального анализа.

\section{Заключение}

Еще раз подчеркнем, что экономическая теория и экономическая социология различаются не объектами исследования и не методами сбора данных. Они представляют специфические подходы к анализу хозяйственных отношений и пытаются решить разные типы исследовательских задач.

«Бедный» английский язык не предоставляет простых способов для разграничения указанных подходов, побуждая вводить разные значения «экономического» ${ }^{25}$. В русском

${ }^{24}$ de Certeau, M. The Practice of Everyday Life. Berkeley: University of California Press, 1988. P. 34-39.

${ }^{25}$ См., например: Поланьи $K$. Экономика как институционально оформленный процесс (фрагмент) // Экономическая социология, 2002. Т. 3, № 2 / www.ecsoc.msses.ru; Полани 
языке принципиальных возможностей больше. И здесь уже используются два разных термина - «экономический» и «хозяйственный», которые в английском языке переводятся одним словом - «есоnomic» ${ }^{26}$. На наш взгляд, первый подходит, скорее, для обозначения более узкого, традиционного экономического подхода, а второй - для более широкого, экономико-социологического подхода.

K. Два значения термина «экономический» / Шанин Т. (ред.). Неформальная экономика: Россия и мир. М.: Логос, 1999. С. 505-513.

${ }^{26}$ Российский экономист Н.Д. Кондратьев еще в 1930-е гг. обращал внимание на то, что английская литература не знает термина «хозяйство», который установился преимущественно в немецком языке и был заимствован российскими исследователями из немецкой традиции (См.: Кондратьев Н.Д. Основные проблемы экономической статики и динамики. М.: Наука, 1991. С. 72). 
$\boldsymbol{V} \boldsymbol{R}$ Мы продолжаем публиковать главы новой книги Вадима Волкова о силовом предпринимательстве. На наш взгляд, это одна из наиболее интересных глав, она посвящена эволюции воровского мира под воздействием приходящей ему на смену бандитской культуры.

\title{
СИЛОВОЕ ПРЕДПРИНИМАТЕЛЬСТВО В СОВРЕМЕННОЙ РОССИИ
}

\section{Глава 4. Воры и бандиты}

\author{
Волков Вадим Викторович \\ Европейский университет в Санкт-Петербурге \\ Email: Volkov@eu.spb.ru
}

Прежде чем обратиться к вопросу организации и деятельности различных силовых структур в соответствии с классификацией, предложенной в Главе 2, необходимо остановиться подробнее на проблеме соотношения преемственности и изменения в преступном мире России после распада системы государственного социализма. Напомним, что основным объектом исследования в данной книге являются частные организации, владеющие средствами принуждения или силовыми ресурсами и использующие их для извлечения прибыли во взаимодействии с хозяйствующими субъектами, - т.е. организации, занятые силовым предпринимательством. Аналитически именно владение и специфическое использование силового ресурса, a не институциональная принадлежность или правовой статус являются основным признаком для выделения упомянутых организаций в одну группу. Вместе с тем, по мере эмпирического наполнения аналитических категорий возникает необходимость учета всевозможных отличий и сравнения экономической деятельности различных силовых структур, анализа их взаимодействия друг с другом и их эволюции. Из того, что различие между организациями, квалифицируемыми правоохранительными органами как «преступные» (ОПГ), и другими силовыми структурами является для нас аналитически не значимым, не следует, что мы собираемся игнорировать эмпирические различия между ними. Более того, внутри самого преступного мира также существуют серьезные различия, порождающие противоречия и конфликты. До сих пор, говоря о незаконных силовых структурах, мы в основном подразумевали организации, члены которых не имели значимого биографического отношения к традиционному уголовному миру и использовали навыки своей прошлой профессии (спорт, милицейская или армейская служба) для занятия силовым предпринимательством в изменившихся экономических условиях. Но наряду с этими группами важную роль в формировании постсоветской преступной среды сыграли представители традиционного уголовного мира, активно формировавшегося еще в годы первых пятилеток. Они наложили свой отпечаток на развитие силового предпринимательства, но при этом и сами были вынуждены адаптироваться к меняющимся социально-экономическим условиям. Общественные изменения, разрушившие систему государственного социализма, в не меньшей степени коснулись и ее «двойника» - традиционного уголовного мира, вызвав раскол, конфликты и выхолостив его нормативно-идеологическое содержание. Появление новых преступных группировок, специализировавшихся на охранном рэкете, а также растущая капитализация преступных доходов в течение всего лишь нескольких лет изменили почти все аспекты жизни представителей старого уголовного мира, оставив, по сути, только фасад. Жаргон и так называемые «понятия», которые они стремились передать или навязать новому поколению преступников, тоже были переосмыслены и адаптированы к новым формам деятельности. Поэтому несмотря на часто декларируемую 
преемственность постсоветского уголовного мира, для более адекватного понимания его динамики необходимо учитывать прежде всего произошедшие изменения.

\section{Воровской мир}

Специфическое уголовное братство, известное как воровской мир, сложилось в советских тюрьмах и исправительно-трудовых колониях в 1930-е гг. Со времени первого научного исследования языка и культуры воровского мира, опубликованного будущим специалистом по древнеславянской литературе академиком Дмитрием Сергеевичем Лихачевым в 1935 г., этот предмет привлекал многих российских и зарубежных исследователей ${ }^{1}$. На их работах и основан нижеследующий анализ.

Воровской мир можно назвать неформальным сообществом и субкультурой, объединявшей «профессиональных» преступников со значительным уголовным стажем. Основное назначение воровского мира - регулировать как свои внутренние отношения, так и отношения уголовной среды с внешним миром. Особый жаргон, манера держаться, мифология, ритуалы приема и исключения, кодекс норм, иерархическая организация, общие денежные фонды - все это относится к основным отличительным чертам воровского мира. Его элита, лидеры преступного мира, известны как «воры в законе». Часто слово «вор» используется для обозначения именно члена особой уголовной элиты и подразумевает вора в законе, а не просто представителя преступной профессии, занимающегося какими-либо видами краж. В то же время воровской мир включает не только «коронованных» воров, т.е. воров в законе, но и всех тех, кто придерживается правил и идеологии воровской жизни и чья карьера связана исключительно с определенными преступными занятиями и иерархией, принятой в уголовной среде. Далее мы будем использовать слово «вор» для обозначения любого члена воровского мира, а когда речь будет идти непосредственно о членах правящей элиты этого мира, будем говорить «вор в законе» или «законник».

Воровской мир имеет много предшественников, но где именно он берет свое начало неясно. В своих основных чертах он сформировался в 1930-е гг. вместе с системой ГУЛАГа и во многом посредством самой системы. Благодаря перемещению по этой системе больших масс заключенных в ней множились связи, усваивались нормы, передавались указания, информация и другие элементы, необходимые для распространения организации и идеологии как внутри, так и за пределами пенитенциарной системы. Поскольку предназначением воровского сообщества были организация и управление заключенными, выживание и воспроизводство преступного мира в экстремальных условиях советских тюрем и исправительных лагерей, тюремная жизнь, «зона», была точкой отсчета всей системы норм и организации этого сообщества. Те, кто выходил на свободу, несли ее нормы в гражданскую жизнь, но при этом воры были, по сути, бывшими или будущими зеками: жизнь на свободе рассматривалась как

\footnotetext{
${ }^{1}$ Вот лишь основные работы: Лихачев Д. Черты первобытного примитивизма воровской речи // Язык и мышление. Труды Академии Наук CCCP, T. III-IV. М.: Академия наук, 1935; Гуров А. Профессиональная преступность. М.: Юридическая литература, 1990; Гуров А., Рябинин И. Исповедь вора в законе. М.: Росагропромиздат, 1991; Абрамкин В., Чижсв Ю. Как выжить в советской тюрьме. Красноярск: Агентство «Восток», 1992; Разинкин B. Воры в законе и преступные кланы. М.: Криминологическая ассоциация, 1995; Chalidze, V. Criminal Russia: Essays on Crime in The Soviet Union. N.Y.: Random House, 1977; Serio, J., and V. Razinkin. Thieves Professing the Code: The Traditional Role of Vory $v$ Zakone and Adaptations to a New Reality, Low Intensity Conflict and Law Enforcement (1995). Vol. 4, No.1. P. 72-88; Varese, F. The Society of the Vory-v-Zakone, 1930s-1950s, Cahiers du monde russe (1999). Vol. 39, No. 4. P. 515-538.
} 
временная, после нее они все равно рано или поздно возвращались в зону. Несмотря на открытое противостояние между властями и воровским миром, лагерное начальство нуждалось в услугах воров в законе и даже зависело от них в вопросах поддержания порядка и улаживания конфликтов, поскольку могли управлять другими заключенными гораздо эффективнее. В целом, чем более жестким и репрессивным становился советский политико-правовой режим, тем более организованным и сильным становился уголовный мир.

Не претендуя на всеобъемлющее исследование этого явления, мы можем, тем не менее, попытаться социологически реконструировать основные черты воровского сообщества. Для этого необходимо понять систему норм, поддерживаемых в этом сообществе, и их функциональное предназначение. Первое и основное правило устанавливало запрет на сотрудничество с властями или работу в каких-либо государственных учреждениях. Человек, который когда-либо в своей жизни служил в армии или работал на советское государство, не мог претендовать на полноправное членство в воровском сообществе, не говоря уже о звании вора в законе. Запреты на какое-либо сотрудничество с властями выполняли функцию поддержания границы между двумя мирами и, соответственно, воспроизводства уголовного мира как отдельной реальности. Соблюдение этой и других норм должны были контролировать воры в законе.

«Основным коллективным представлением воров, определявшим их отношение к внешней реальности, была идея борьбы двух миров», - пишет Лихачев. - «Вор, как первобытный человек, делит весь мир на две части: “свой” - “хороший”, и «чужой” “плохой”» ${ }^{2}$. Явное и последовательное отрицание всего, что было связано с официальной системой, включая приказы и распоряжения властей, составляло основную черту поведенческой идиомы вора, чего бы это ему ни стоило. Основные нормы и принципы воровского мира представлялись в виде лаконичных высказываний, сопровождавших татуировки на теле заключенного. Так, распространенная татуировка гласила: «Авторитетный вор - непримиримый отрицала» ${ }^{3}$. Такое поведение часто провоцировало суровые наказания со стороны лагерного начальства, наиболее распространенным из которых было помещение в карцер. Но после того, как «мученик» отбывал положенное наказание, его статус в воровском сообществе повышался, и на его теле появлялась татуировка, отмечавшая этот эпизод в карьере заключенного. Так тело заключенного становилось своего рода книгой, по которой другие могли прочитать воровские нормы и личную историю отсидок и подвигов носителя татуировок, - если, конечно, они умели «читать», т.е. знали особый код. Из-за этой практики татуировок среди воров представители традиционного уголовного мира получили прозвище «синие» - по цвету телесной росписи.

Чем сильнее воры отрицали все, что было связано с формальной советской системой, тем больше они были преданы своему сообществу. Следующий комплекс норм касался солидарности уголовного братства и преданности воровской профессии. Функция этих норм - интеграция и поддержание солидарности. Если человек выбирал воровской путь и стремился достичь вершины в уголовной иерархии, ему было запрещено иметь жену и семью, равно как и культивировать какие-либо родственные связи, которые требовали бы лояльности к какому-либо другому сообществу. Известная татуировка «Не забуду мать родную» на самом деле не имеет ничего общего с биологической матерью. «Мать» здесь обозначает, скорее, воровскую семью, которая дала своему питомцу второе рождение и настоящее воспитание. Такое прочтение подсказывает и то обстоятельство, что в

\footnotetext{
2 Лихачев Д. Черты первобытного примитивизма воровской речи / Балдаев Д. (ред.) Словарь тюремно-блатного жаргона. М.: Края Москвы, 1992. С. 366.

${ }^{3}$ Балдаев Д. (ред.) Словарь тюремно-блатного жаргона. С. 462.
} 
предвоенные годы большинство из тех, кто начинал воровскую карьеру в юности, - а это очень важная часть воровских заслуг, - были беспризорниками, сбежавшими из интернатов и не знавшими своих родителей. Обещание «не забывать родную мать», как и клятвы верности воровской идее, произносимые при коронации, подчеркивали верность коллективу. Сюда же следует отнести и комплекс запретов на какую-либо работу. Помимо явного неприятия властей, которые заставляли работать и непослушание которым являлось сердцевиной воровского «кодекса чести», этот запрет еще поддерживал исключительную лояльность воровской профессии: вор должен жить только с украденного.

Назначение еще одного комплекса норм - регулировать отношения между членами воровского сообщества, включая воров в законе. Функцию этих норм можно обозначить как посредничество или снятие противоречий. Согласно общепринятым представлениям, уголовная среда отличается чрезвычайно высоким уровнем насилия. Вместе с тем, насилие является предметом жесткого регулирования. В воровской среде на спонтанное физическое насилие, особенно убийство, налагался запрет, нарушение которого предполагало суровые санкции (кроме случаев, когда насилие санкционировалось ворами в законе). Контролирование насилия относилось к одной из наиболее важных функций воров в законе. Решение об убийстве вора могло приниматься только на сходке в случае предательства или серьезного оскорбления им других воров. Воры были носителями норм, в соответствии с которыми разрешались конфликты и осуществлялось правосудие. По словам одного из наиболее влиятельных воров в законе Евгения Васина («Джема»), «вором в законе называют человека, который может правильно рассудить, развести без крови» ${ }^{4}$. Вора в законе иногда называли просто «законник», т.е. тот, кто владеет сводом уголовных законов и трактует их. По словам одного из респондентов, «вор в законе - это как доктор неформального права» [1].

Наконец, к нормам, относящимся к поддержанию границы, интеграции, снятию противоречий, необходимо добавить нормы, касающиеся экономической стороны воспроизводства воровского сообщества. Его основой была система общаков, т.е. общих фондов, которые пополнялись за счет воровского промысла и служили для поддержания тех, кто находился в зоне. «Классический» общак функционировал по социалистическому принципу. Предполагалось, что все представители воровской профессии должны сдавать свою добычу или выручку в общий фонд, общак, и получать из него некоторую долю на повседневные нужды. Основная же часть общака предназначалась для того, чтобы «греть зону», т.е. для обеспечения заключенных продуктами, табаком, алкоголем, наркотиками, а также для подкупа властей. Общак также предназначался для помощи тем, кто недавно освободился из мест заключения и первоначально не имел средств. Таким образом, система поддержки заключенных и само знание о ее существовании снижали страх перед зоной, смягчали возможные лишения во время пребывания в ней и тем самым повышали степень преданности преступным профессиям. Как утверждает известная татуировка, «тюрьма - дом родной».

Воры в законе отвечали за пополнение и распоряжение общаком. Поведенческие нормы воров в законе, требующие аскетизма, запрещающие роскошь и дозволяющие лишь необходимый минимум обихода, были логически связаны именно с функцией распоряжения общими фондами. Роскошь могла вызвать подозрение в присвоении и растрате общаковских денег, что по воровским понятиям каралось смертью. Кроме того, необходимость поддержания образа вора в законе как олицетворения веры в воровскую идею и верности понятиям превращала многих воров старого стиля в аскетов, страдальцев за идею, уголовных аналогов святых. Ведь их власть держалась не на богатстве и не на

\footnotetext{
${ }^{4}$ Коммерсантъ, 2001. 5 октября. С. 12.
} 
насилии, а преимущественно на специфическом моральном авторитете, поддерживаемом уголовной традицией.

Как становился вором в законе? Чтобы претендовать на это звание, необходимо было иметь «чистую» уголовную биографию. Она должна была начинаться в достаточно молодом возрасте, не содержать никаких эпизодов работы на государство или связи с властями, включать впечатляющий послужной список «отсидок», причем только по определенным, «благородным» статьям («изнасилование», например, считалось неприемлемой статьей), и эпизоды «правильного» поведения по отношению к воровскому братству. Авторитетный вор Вася Бузулутский, например, получил свой первый срок в возрасте четырнадцати лет и с небольшими перерывами провел почти сорок лет в различных тюрьмах и лагерях. Другой легендарный вор старой формации Владимир Бабушкин («Васька-бриллиант») сделал десять «ходок» (т.е. был осужден на различные сроки 10 раз), что заняло почти всю его жизнь ${ }^{5}$. Кандидат на звание «вор в законе» должен был заслужить уважение своим характером, сообразительностью, лояльностью традиции понимаемым, конечно, с точки зрения криминальной профессии. Ритуал коронации должен проводиться на сходке с предоставлением не менее трех рекомендаций воров в законе. Его основным элементом являлась клятва верности воровской семье и ее законам.

Конечно, сложный и закрытый воровской мир нельзя свести лишь к набору норм и соответствующих функций. Многое осталось за рамками данного краткого анализа. Но большинство этих норм, возникших еще в довоенное время, сохранились до 1980-х гг., как и сам традиционный уголовный мир. В приведенном описании мы стремились выделить лишь те черты, которые образуют идеальный тип традиционного уголовного подполья советских времен, поскольку систематическое сравнение воров и бандитов, старого и нового типа преступности возможно лишь как идеально-типическое.

\section{Сравнение идеальных типов}

Те, кого в современной России называют «бандитами», мало напоминают классических бандитов прошлого - обитателей гор или лесов, смертельных врагов властей, предводителей крестьянских восстаний или просто грабителей, рано или поздно заканчивавших свою жизнь на эшафоте 6 . Сегодня это стационарные городские бандиты, активно участвующие в деловой и политической жизни, но в любой момент готовые прибегнуть к насилию. Если о «головорезах» прошлого слагались легенды и предания, то современный бандит является любимым героем городского фольклора, популярных романов и телесериалов. Его можно легко распознать по физическим габаритам, жестам, речи, стрижке, одежде и, конечно, «БМВ» («боевая машина вымогателей»), «Мерседесу» или джипу. Но это внешний аспект. Как уже указывалось в предыдущей главе, его социальное определение - силовой предприниматель.

В отличие от бандитов, воры не являются силовыми предпринимателями. Основная задача вора - воровство (в широком смысле) и стремление избежать поимки. Воры ничего не производят и должны быть незаметны, по крайней мере за пределами своей среды. Бандит же, напротив, считает себя производителем определенных услуг и позиционирует себя соответствующим образом перед клиентами. Его производительность и способность влиять на экономическую деятельность происходят из возможности распоряжения организованной силой. Эта способность должна быть наглядна, поскольку представляет собой основной рыночный ресурс этой группы. Отсюда многочисленные внешние атрибуты, знаки отличия (стрижки, золотые цепи, перстни и т.п.) и легко узнаваемый

\footnotetext{
${ }^{5}$ Модестов Н. Москва бандитская. М.: Центрполиграф, 1996. С. 79-80.

${ }^{6}$ См.: Hobsbawm, E. Bandits. L.: Delacorte Press, 1969.
} 
«самоутверждающий» стиль поведения. В отличие от бандитов, представителей воровской профессии гораздо труднее выделить из общей массы.

Доход вора связан со вторичным перераспределением собственности и в основном состоит из присвоения личного имущества других граждан или государства. Бандит же претендует на долю прибыли других предпринимателей, которая, как он считает, произведена при покровительстве или содействии организованной группы, которую он представляет. Поэтому его доход связан с перераспределением прибавочного продукта и носит характер регулярного налога (на прибыль или с оборота). Поскольку бандиты, сами будучи предпринимателями, стремятся получать доход на постоянной основе и в рамках долговременных отношений, они претендуют на право охраны собственности и порядка и в силу этого могут даже бороться с воровством, например, выгоняя воров из гостиниц, ночных клубов или вещевых рынков.

Воровская этика представляет собой проекцию ценностей и правил тюремной жизни на нормальную жизнь. Источником воровского авторитета служат сроки, проведенные в тюрьмах и колониях. Бандитские понятия сформировались на воле, поэтому они гораздо практичнее и рациональнее, лишены многочисленных запретов. Сотрудничество с властями и даже правоохранительными органами не является для бандитов проблемой, особенно если это приносит конкретные материальные выгоды. Бандитский авторитет формируется не столько в тюрьме, сколько через решительные силовые действия, умение применять силу в сочетании с определенными организаторскими способностями. В отличие от традиционных представителей воровского мира, которые полагались на силу аргумента и могли «завиноватить» кого угодно, бандиты полагаются исключительно на аргумент силы. Их способ действия, по сути, представляет собой элементарную форму политической власти, в основе которой, как известно, лежит способность к физическому принуждению. Воровская власть в гораздо большей степени зависит от морального авторитета и силы традиции; это пример нормативной власти.

Многие бандитские группировки культивировали здоровый образ жизни, запрещая, в отличие от воров, алкоголь и наркотики и поддерживая физическую форму в спортивных залах, где они регулярно собирались. Наконец, в отличие от воровского общака, который функционировал, скорее, по социалистическому принципу центральной перераспределительной системы, бандитские общаки напоминают банки, капитал которых складывается из процентных отчислений членов группировок и может использоваться как для крупномасштабного подкупа властей, так и для инвестиций в легальный бизнес. Если нормативная система воровского мира была подчинена групповому выживанию в жестких условиях советских лагерей и тюрем, то бандитские нормы функционально связаны с участием этой группы в экономической жизни в качестве силовых предпринимателей. Таким образом, воровской мир - продукт сильного репрессивного государства; бандитский мир - продукт незаконного использования силы в условиях слабого государства.

\section{Конфликт и рационализация}

Различия между воровской и бандитской субкультурой порождали многочисленные противоречия и конфликты. По свидетельству Андрея Константинова, Владимир Кумарин, лидер «тамбовских», отрицал воровскую идеологию и отзывался о ворах с презрением: «Зачем дармоедов кормить?»7. Многие авторитеты относились к ворам в законе как к пережиткам прошлого и отказывались следовать воровским понятиям. Воры, в свою очередь, отвечали им презрительным отношением, называя их просто

\footnotetext{
${ }^{7}$ Константинов А. Бандитский Петербург’98. М.: Олма-Пресс, 1999. С. 74.
} 
«спортсменами». Они обвиняли «спортсменов» в приверженности насилию, в тупоумии и амбициозности, но за этим скрывались и реальные опасения по поводу безжалостной экспансии новых бандитов и их нежелания считаться с чем-либо, кроме голой силы. Описывая преступный мир Екатеринбурга, С. Ханделман приводит разговор с уголовным авторитетом старой формации, который с досадой признает, что новые молодые бандиты уже не выказывают никакого уважения таким, как он: «То, что сейчас происходит, ужасно. Старые ценности ушли» ${ }^{8}$. Константинов цитирует исповедь вора в законе Юрия Алексеева («Горбатого»), который описывает, как старая уголовная традиция деградирует под влиянием тех, кто «только силу и уважают, никак не мозги» 9

Нормативные противоречия переплетались с конфликтами конкретных экономических интересов. Гибкость, прагматизм и агрессивность бандитов позволили им быстро захватывать значительные сегменты формирующихся рынков, навязывать охранные услуги частному бизнесу, изобретать различные способы зарабатывания денег. Воры в законе, в свою очередь, стремились подчинить своему влиянию молодых бандитов, навязывая им свою идеологию, мобилизуя уголовные связи или используя силу. Константинов также приводит выдержку из письма воров в законе, конфискованного администрацией в одной из колоний: «...Ознакомиться с этой малявой всем достойным людям, принять к жизни и поставить в курс всех. Все достойные обязаны помогать в сборе общака (денег) на воровские нужды. Все кооперативы обязаны платить определенную часть денег в воровской общак. Все это должно контролироваться людьми из арестантского мира, но ни в коем случае не спортсменами и не другими собаками...» ${ }^{10}$. Раздел сфер влияния порождал конфликты, выражавшиеся в войнах группировок или цепочках заказных убийств. Один из наиболее известных эпизодов такой войны последовательный отстрел киллерами из Кургана по заданию «ореховских» бандитов во главе с «Сильвестром» (Тимофеевым) в 1992 г. в Москве верхушки «таганской» группировки воровской направленности. В результате многочисленных войн установилось определенное деление регионов на бандитские и те, которые «под ворами». Так, Петербург, Екатеринбург и Новосибирск считаются преимущественно бандитскими; влияние воров в законе в них относительно слабо. В Москве же после многочисленных конфликтов и переговоров установилось равновесие, позволяющее сотрудничество или мирное сосуществование группировок различной ориентации. Воровскими считаются Дальний Восток и южные регионы России ${ }^{11}$.

Под воздействием усиливающейся конкуренции воры были вынуждены адаптироваться, приспосабливать свои нормы и организацию к новой реальности, основанной на коммерческом расчете и насилии. Постепенно основные воровские заповеди превращались в лозунги, скрывавшие изменившуюся практику. Следует заметить, что первые признаки разложения воровских понятий появились гораздо раньше, вместе с растущей коррупцией самой советской системы в брежневский период. В 1982 г. на сходке в Тбилиси воры в законе обсуждали, должны ли они участвовать в политике. Грузинские воры настаивали на том, что необходимо расширять отношения с коррумпированной номенклатурой и через нее реализовывать свои интересы. Им противостояли российские блюстители чистоты понятий во главе с Васькой-Бриллиантом, считавшие невозможным нарушение главного запрета. Возникший раскол с годами только увеличивался, и многие грузинские воры (как, например, Джаба Иоселиани, ставший в

\footnotetext{
${ }^{8}$ Handelman, S. Comrade Criminal: Russia's New Mafiya. New Heaven: Yale University Press, 1995. P. 88.

${ }^{9}$ Константинов А. Бандитский Петербург'98. С. 88.

${ }^{10}$ Там же. С. 73.

${ }^{11}$ Разинкин В. Воры в законе. С. 17; Константинов А. Бандитский Петербург'98. С. 74-77.
} 
определенный период правой рукой главы независимого грузинского государства) продолжали активно проникать во власть ${ }^{12}$.

С началом перестройки и распадом СССР молодое поколение воров в законе попыталось возродить уходящую традицию, при этом существенно изменив ее содержание. Тюремная жизнь уже плохо сочеталась с растущими экономическими интересами уголовного мира: попасть в зону означало потерять контроль над многочисленными коммерческими проектами. Соответственно, тюремный стаж сокращался и терял свою значимость. С другой стороны, в 1990-е гг. стало возможным купить титул «вора в законе» в сравнительно молодом возрасте, не имея послужного списка и уголовного стажа, типичный признак разложения для любой традиционной элиты. Формально этот титул давал право принимать участие в управлении уголовным миром и криминальным капиталом. И хотя степень уважения к купленному титулу едва ли могла достигнуть прежних высот, экономическое влияние вполне компенсировало этот недостаток. Так, в 1990-1992 гг. молодой вор новой формации Леня «Макинтош» вошел в состав московского банка «Столичный» для распоряжения «общаковскими» средствами, составлявшими часть капитала банка, через который в эти годы было введено в легальный оборот более 10 млрд. рублей ${ }^{13}$.

Меняющаяся функция общака свидетельствует о возрастающей рационализации воровского мира под воздействием изменившейся социально-экономической среды. $\mathrm{C}$ появлением возможностей для капиталистического предпринимательства и особенно с развитием банковского сектора все возрастающая доля криминальных ресурсов капитализировалась - вместо того, чтобы идти на потребление пенитенциарной системы. «Общаковские» средства вкладывались в существующие банки или образовывали начальный капитал для новых банков, чтобы затем инвестироваться в легальный бизнес (в основном в торговлю и импортно-экспортные операции). И хотя значительные средства продолжали направляться в «зону», общаки уже работали не на идею, а на производство прибыли, которая присваивалась их распорядителями, т.е. ворами в законе.

Выхолащивание нормативного содержания воровской субкультуры и ее превращение в специфический тип капиталистического предпринимательства можно проиллюстрировать на примере карьеры Павла Захарова («Паши-Цируля»), одного из наиболее влиятельных «законников» старой формации. Он начал свою уголовную карьеру в 1950-е гг. с карманных краж, наиболее престижной воровской профессии, и получил первый срок, когда ему было пятнадцать лет. Последующие пять тюремных сроков заняли в совокупности более двадцати лет жизни. Благодаря своим талантам и авторитету к 1980-м гг. Паша-Цируль стал самым влиятельным «законником» в Москве и распорядителем крупнейшего общака. Он построил себе в Подмосковье трехэтажный особняк с подземным ходом и гаражом, где содержал пять престижных иномарок и микроавтобус. В нарушение еще одной воровской нормы он был фактически женат, хотя формальным мужем его жены был зарегистрирован его брат. Ортодоксальный вор в законе Вася-Очко обвинил Цируля в присвоении и растрате общаковских денег, в частности в «прокручивании» их через кооперативы и присвоении прибыли. Согласно воровским понятиям, такое обвинение означало, в случае его доказательства, смертный приговор. Конфликт между двумя лидерами обсуждался на многочисленных сходках и был «разрешен» лишь посредством устранения Васи-Очко. Захаров тем временем создал сильную преступную группировку, которая занялась предоставлением охранных услуг, легальным бизнесом и торговлей наркотиками. В декабре 1994 г. он был арестован и провел более двух лет под следствием. Павел Захаров (Цируль) не дожил до суда,

\footnotetext{
${ }^{12}$ Serio, J., and V. Razinkin, Thieves Professing the Code. P. 76.

${ }^{13}$ Разинкин В. Воры в законе. С. 64.
} 
скончавшись в тюрьме от передозировки наркотиков в январе 1997 г. ${ }^{14}$ Символическим финалом его карьеры стало письменное отречение, которое, согласно некоторым источникам, он написал на имя главного прокурора Москвы незадолго до смерти, пытаясь тем самым добиться права выйти из тюрьмы под залог: «Прошу больше не считать меня вором в законе. Поскольку в 1953 году был коронован неправильно, с нарушением воровских законов и традиций» 15 .

${ }^{14}$ Модестов Н. Москва бандитская. С. 103-105; Трабарин А. Воры в законе и авторитеты. М.: Эксмо-Пресс, 2000. С. 98-125.

${ }^{15}$ Цит. по: Трабарин А. Воры в законе и авторитеты. С. 125. 


\title{
Новые переводы
}

$\boldsymbol{V R}$ Предлагается перевод первой части статьи, которая является самым цитируемым текстом в современной экономической социологии. Заметим, что это первый из известных нам русских переводов М. Грановеттера - признанного лидера новой экономической социологии. Полный перевод текста, предлагаемого в данном номере, увидит свет позднее - в рамках подготавливаемой нами хрестоматии «Западная экономическая социология».

\section{ЭКОНОМИЧЕСКОЕ ДЕЙСТВИЕ И СОЦИАЛЬНАЯ СТРУКТУРА: ПРОБЛЕМА УКОРЕНЕННОСТИ ${ }^{1,2}$}

\section{Марк Грановеттер}

\author{
Перевод М.С. Добряковой
}

Научное редактирование - В.В. Радаев

\section{Введение: проблема укорененности ${ }^{3}$}

Как социальные отношения влияют на поведение и институты - таков один из основных вопросов классической социальной теории. Поскольку такие отношения существуют всегда, то представить ситуацию, которая возникла бы при их отсутствии, можно лишь путем мыслительного эксперимента, подобного «естественному состоянию» [state of nature] по Т. Гоббсу или «оригинальной позиции» [original position] в концепции Дж. Роулза ${ }^{4}$. Значительная часть утилитаристской традиции, включая классическую и неоклассическую экономическую теорию, построена на представлении о рациональном поведении, следующем собственному интересу и лишь в минимальной степени

${ }^{1}$ Переведено по: Granovetter, Mark. Economic Action and Social Structure: The Problem of Embeddedness, American Journal of Sociology (November 1985). Vol. 91. P. 481-510.

${ }^{2}$ Более ранние версии этой работы были написаны во время творческого отпуска, любезно предоставленного мне Институтом перспективных исследований и Гарвардским университетом. Финансирование осуществлялось вышеназванным Институтом, а также Мемориальным фондом памяти Джона Саймона Гуггенхайма и Национальным научным фондом в рамках программы профессионального развития научных и преподавательских кадров (грант № SPI 81-65055). Работе над статьей способствовали Уэйн Бейкер, Майкл Бернстайн, Альберт Хиршман, Рон Джесперсон, Эрик Лифер, Дон МакКлоски, Чарльз Перроу, Джеймс Рул, Майкл Шварц, Теда Скокпол и Хэррисон Уайт.

3 Автор использует термин «еmbeddedness», который мы переводим как «укорененность» (второй возможный перевод - «встроенность»). Понятие укорененности противопоставляется в работе понятию атомизированности. - Прим. перев.

${ }^{4}$ В своей книге «Теория справедливости» (1971) Роулз делает попытку использовать конструктивистскую методику для выявления основных принципов справедливости. Суть методики состоит в том, чтобы сконструировать воображаемое государство будущего, не зная своей расовой, социальной и экономической позиции в нем. Таким образом, «оригинальная методика» предполагает абстрагирование от собственного статуса и осуществление анализа в воображаемой плоскости. - Прим. перев.

http://philosophy.about.com/gi/dynamic/offsite.htm?site=http $\% 3 \mathrm{~A} \% 2 \mathrm{~F} \% 2 \mathrm{Fwww}$.geocities.co m\%2FAthens\%2FParthenon\%2F1643\%2Frawls.html;

http://www.peter-club.spb.ru/library/Rawls.html. 
подвластном социальным отношениям, что и создает идеализированную ситуацию, приближающуюся к этим мыслительным экспериментам. На противоположном полюсе находится то, что я называю аргументом «укорененности»: поведение и институты, которые мы намерены анализировать, настолько ограничены существующими социальными отношениями, что пытаться представить их как независимые было бы грубейшей ошибкой.

В данной статье рассматривается укорененность экономического поведения. Долгое время большинство социологов, антропологов, политологов и историков полагали, что такое поведение было прочно укоренено в социальных отношениях дорыночных обществ, однако с наступлением периода модернизации оно стало гораздо более автономным. Согласно этой позиции, экономика представляет собой все более независимую, обособленную сферу современного общества. Экономические трансакции в ней определяются уже не социальными или родственными обязательствами тех, кто эти трансакции осуществляет, а рациональными расчетами индивидуальной выгоды. Иногда авторы идут еще дальше, утверждая, что теперь мы имеем дело с зеркальным отражением традиционной ситуации: уже не экономическая жизнь подчинена социальным отношениям, а эти отношения становятся эпифеноменом рынка. Гипотеза укорененности связывается с «субстантивистской» школой [substantivist school] в антропологии, ассоциируемой прежде всего с именем Карла Поланьи [Polanyi 1944; Polanyi, Arensberg, and Pearson 1957] и с идеей «моральной экономики» в истории и политической науке [Thompson 1971; Scott 1976]. Есть у нее и очевидная связь с марксистской традицией.

Однако лишь немногие экономисты считают, что экономические отношения перестали быть укорененными в социальных именно с началом модернизации. Большинство из них полагают, что в ранних обществах степень такой укорененности была не намного выше, чем в условиях современных рынков. Тон был задан Адамом Смитом, отметившим «склонность к мене, торговле, обмену одного предмета на другой» ${ }^{5}$ [Smith (1776) 1979, кн. 1, гл. 2]. Раз труд был единственным фактором производства в примитивном обществе, полагал он, то обмен товарами должен был осуществляться на основании трудовых затрат, как это провозглашено классической теорией обмена [Smith (1776) 1979, кн. 1, гл. 6]. Начиная с 1920-х гг. некоторые антропологи заняли сходную позицию, получившую название «формалистской» [formalist]: даже в родовых общинах экономическое поведение было в достаточной степени независимым от социальных отношений, что позволяет использовать для его анализа неоклассическую теорию [Schneider 1974]. Недавно эта позиция получила подкрепление: экономисты и их коллеги историки и политологи - попытались подойти к экономическому анализу социальных институтов под новым углом зрения. Их позиция получила название «новой институциональной экономики» [new institutional economics]. Они утверждают, что экономические поведение и институты, которые, как считалось прежде, укоренены в социальных отношениях (и в ранних обществах, и в современных обществах), на самом деле могут быть лучше поняты как результат действий рациональных, более или менее обособленных [atomized] индивидов, преследующих свой эгоистический интерес [North and Thomas 1973; Williamson 1975; Popkin 1979].

Мои собственные взгляды отличны от постулатов обеих теоретических школ. Я принимаю положение о том, что в нерыночных обществах степень социальной укорененности экономического поведения слабее, нежели считают сторонники «субстантивистской» школы и теории развития, и она не так сильно уменьшилась с приходом «модернизации», как они утверждают. Однако я полагаю, что степень такой

5 Таков традиционный перевод в российской политической экономии. Мы могли бы предложить другой вариант, представляющийся нам более благозвучным: «склонность человека обмениваться, рядиться и торговаться». - Прим. перев. 
укорененности всегда была и продолжает оставаться более значимой, чем это видится сторонникам «формализма» и экономистам. В мою задачу не входит рассмотрение проблем, которые ставит перед нами анализ нерыночных обществ. Вместо этого я попытаюсь развить теоретическое понятие укорененности и затем показать его значение на примере одной из проблем современного общества, волнующих ныне новую институциональную экономическую теорию, а именно: какие трансакции в современном капиталистическом мире осуществляются посредством рынка, а какие - в рамках иерархически организованных фирм? Этот вопрос был поставлен Оливером Уильямсоном в рамках его исследовательской программы «рынки - иерархии» [Williamson 1975].

\section{Пере- и недосоциализованные концепции человеческого действия в социологии и экономической теории}

Я начну с прозвучавшего еще в 1961 г. сетования Денниса Ронга о «пересоциализованной концепции человека в современной социологии» [oversocialized conception]. Согласно этой концепции, люди крайне чувствительны к мнению окружающих и в силу этого подчиняются диктату согласованных систем норм и ценностей, интериоризируемых в процессе социализации, в результате которой послушание уже не почитается за бремя. Влиятельность этой концепции в начале 1960-х гг. в значительной степени обязана рассуждениям Толкотта Парсонса о проблеме порядка (в стиле Томаса Гоббса), а также его собственной попытке разрешить эту проблему, преодолев присущее утилитаристской традиции (к которой принадлежал и Гоббс) атомизированное и недосочиализованное представление о человеке [atomized, undersocialized conception] [Parsons 1937: 89-94]. Ронг соглашался отойти от утилитаристского представления о человеке как обособленном субъекте и сместить акцент в сторону анализа укорененности акторов в социальном контексте (крайне важный фактор, отсутствующий в рассуждениях Гоббса). Однако при этом он предостерегал против преувеличения глубины этой укорененности и степени, в какой она способна нейтрализовать конфликт:

«Зачастую задачей социолога является привлечение внимания к тому, как люди жаждут заслужить хорошее мнение окружающих в самых разных ситуациях - особенно там, где принятые теории или идеологии неправомерно выдвигали на передний план иные мотивы. ...Так, социологи показали, что фабричных рабочих больше волнует мнение своих товарищей по работе, чем чисто экономические стимулы... Я никоим образом не собираюсь критиковать результаты этих исследований. Суть моего возражения в том, что ...хотя социологи и подвергли критике прошлые попытки вычленения в человеческом поведении одного-единственного фундаментального мотива, в их собственных рассуждениях стремление к высокой самооценке через одобрение со стороны окружающих зачастую начинает рассматриваться именно как такой мотив» [Wrong 1961: 188-189].

Классическая и неоклассическая экономическая теория, напротив, продолжая утилитаристскую традицию, оперируют атомизированной, недосоциализованной концепцией человеческого действия. Теоретические аргументы изначально отвергают всякое влияние социальной структуры и социальных отношений на производство, распределение и потребление. В условиях конкурентных рынков ни один производитель или потребитель не оказывает сколько-нибудь заметного влияния на совокупный спрос или предложение, а значит, на цены и прочие условия торговли. Как отметил Альберт Хиршман, такие идеализированные рынки, на которых действует «множество анонимных покупателей и продавцов, ориентирующихся на цены и снабженных полной информацией..., функционируют без какого бы то ни было длительного человеческого или социального контакта между участниками. В условиях совершенной конкуренции нет места торгу, переговорам, выражению несогласия или взаимному приспосабливанию; 
различным акторам, связанным контрактными обязательствами, нет необходимости вступать в повторяющиеся или длительные отношения, в результате которых они могли бы лучше узнать друг друга» [Hirschman 1982: 1473].

Давно признано, что этот идеализированный образ рынка совершенной конкуренции сумел выдержать интеллектуальные нападки отчасти по той причине, что идея саморегулирующихся экономических структур для многих привлекательна с политической точки зрения. Еще одна, менее четко осознаваемая причина его жизнеспособности состоит в том, что устранение социальных отношений из экономического анализа вычеркивает из списка интеллектуальных задач и проблему порядка, по крайней мере в экономической сфере. Согласно Гоббсу, беспорядок возникает потому, что лишенные конфликтов социальные и экономические трансакции зависят от наличия доверия и отсутствия мошенничества [malfeasance]. Однако такая ситуация маловероятна, коль скоро индивиды полагаются в своем «естественном состоянии» - вне социальных отношений и институционального контекста. Гоббс разрешает эту проблему, указывая на наличие некоей вышестоящей автократической структуры. Классический либерализм (и, соответственно, классическая экономическая теория) предлагает противоположное решение: репрессивные политические структуры оказываются не нужны, под влиянием конкурентных рынков устраняются сила и обман [fraud]. Конкуренция определяет условия торговли так, что ее участники-индивиды не могут жульничать. Если торговцы сталкиваются с многоуровневыми или сложными отношениями недоверия или мошенничества, они просто могут обратиться к огромной массе других торговцев, готовых заниматься бизнесом по рыночным правилам. Тем самым, социальные отношения и все связанные с ними тонкости становятся не более чем помехой.

Следовательно, в классической и неоклассической экономической теории тот факт, что акторы могут вступать друг с другом в социальные отношения, если вообще и рассматривался, то лишь как незначительный фактор, мешающий работе конкурентных рынков. Часто цитируют пассаж Адама Смита, где он сетует, что «люди, занимающиеся одним ремеслом, редко собираются вместе даже для забав и развлечений. Если же они все-таки встречаются, то их общение заканчивается сговором против публики или выработкой хитроумного плана по поднятию цен». Описываемая Смитом политика laissez-faire едва ли допускает какое-то решение этой проблемы, однако сам он предлагал отказаться от правил, обязывающих всех тех, кто занят одним ремеслом, отмечаться в соответствующем публичном реестре. Свободный доступ к подобной информации «связывает между собой индивидов, которые в противном случае никогда не узнали бы друг друга, а также указывает каждому занятому в этом ремесле направление поиска коллег». Примечательно здесь не предписание действий - не вполне неубедительное, - a признание того, что социальная атомизация является предпосылкой совершенной конкуренции [Smith (1776) 1979: 232-233].

В более поздних рассуждениях экономистов «социальные влияния» толкуются как процесс, в ходе которого акторы усваивают обычаи, привычки или нормы и затем следуют им механически, не задумываясь, независимо от своего мнения о рациональном выборе. Эта позиция, близкая к «пересоциализованой концепции» человека по Ронгу, отражена в язвительном замечании Джеймса Дьюзенберри: «Вся экономическая теория посвящена тому, как люди делают выбор, а вся социология посвящена тому, почему люди не имеют никакого выбора» ${ }^{6}$ [Duesenberry 1960: 233]. Проскальзывает она и в описании Эрнстом Фелпсом Брауном «стремления социологов к детерминированности», проистекающего из посылки о том, что люди действуют «определенным образом, потому что это

${ }^{6}$ Цитируется по: Радаев В.В. Экономическая социология: Курс лекций. М.: Аспект-пресс, 1998. C. 55. 
соответствует обычаям или порождено обязательствами или просто потому, что это “естественно” или правильно и уместно, честно и справедливо» [Phelps Brown 1977: 17].

Несмотря на явный контраст между недо- и пересоциализованными взглядами, стоит отметить забавную вещь, имеющую огромное теоретическое значение: в обоих случаях речь идет о концепции действия и принятия решений атомизированными акторами. В недосоциализованной концепции такая обособленность проистекает из посылки об утилитарном следовании акторами своему эгоистическому интересу, а в пересоциализованной концепции - из предположения о том, что модели поведения интериоризированы и, следовательно, существующие социальные отношения оказывают на поведение человека лишь незначительное влияние. То, что интериоризированные правила поведения по своему происхождению имеют социальный характер, не отделяет коренным образом эту позицию от утилитаристской, в которой источник существования функций полезности [utility functions] не определен. И в результате становится возможным поведение, направляемое исключительно консенсусными нормами и ценностями, что вполне соответствует пересоциализованной концепции. Таким образом, недо- и пересоциализованную концепции объединяет решение проблемы порядка - в обоих случаях акторы отделены от своего непосредственного социального контекста. Это причудливое смешение заметно уже в гоббсовском «Левиафане», где несчастные жертвы «естественного устройства», захлестнутые беспорядком, проистекающим из их атомизации, радостно делегируют все свои права авторитарной власти и впоследствии ведут себя мирным и достойным образом. Изобретение общественного договора перемещает их прямиком из недосоциализованного состояния в пересоциализованное.

Когда современные экономисты все же обращаются к анализу социальных воздействий, они обычно представляют их в пересоциализованном виде, как это описано выше. Отказываясь от утверждения о том, что социальное воздействие - это помеха, они сохраняют свои представления по поводу того, как оно осуществляется. Например, в своей теории сегментированных рынков труда Майкл Пиоре утверждает, что члены каждого сегмента характеризуются особым стилем принятия решений и что принятие решений на основе рационального выбора, обычая или приказа в рамках верхнего первичного, нижнего первичного и вторичного рынков труда [upper-primary, lowerprimary, secondary labor markets] соотносится с социальным происхождением работников, связано ли оно с субкультурами среднего, рабочего или низшего класса соответственно [Piore 1975]. Аналогично, Самуэль Баулз и Герберт Гинтис, рассуждая о следствиях американской системы образования, утверждают, что различные социальные классы демонстрируют разные когнитивные процессы в силу различий в образовании, полученном каждым из них. Тех, кому предстоит занять рабочие места низшего уровня, учат послушно следовать правилам, в то время как те, для кого уготованы элитные позиции, получают «элитное четырехгодичное образование в колледже», где «учат социальным отношениям, принятым в высших слоях производственной иерархии... По мере того, как они “овладевают” очередным типом регулирования поведения, они либо занимают соответствующее место в производственной иерархии, либо им позволяют продвигаться дальше» [Bowles and Gintis 1975: 132].

Однако эти пересоциализованные представления о влиянии общества на индивидуальное поведение довольно механистичны: получается, что стоит нам узнать, к какому классу или сектору на рынке труда принадлежит индивид, все остальное в его поведении становится понятно автоматически - так хорошо социализированы индивиды. Социальное воздействие здесь выступает в качестве некоей внешней силы, которая, подобно Богу в деизме ${ }^{7}$, лишь вдыхает в предметы жизнь и этим ограничивает свое

${ }^{7}$ Деизм [фр. deisme / лат. deus бог] - религиозно-философское учение, распространенное в XVII-XVIII вв., признающее бога творцом мира, но отвергающее его участие в жизни 
влияние, в качестве силы, проникающей в умы и тела людей (как в фильме «Нашествие похитителей тел» ${ }^{8}$ ), изменяющей их способ принятия решений. Стоит нам узнать, какого рода влияние было оказано на индивида, и все социальные отношения и окружающие его структуры становятся для нас незначимыми. Все социальные воздействия содержатся в голове человека, так что в ситуации принятия решения он/она может действовать обособленно, как и любой другой Homo economicus, хотя, возможно, правила принятия решений и будут иными. Более сложные (и, значит, не столь пересоциализованные) подходы к анализу культурных влияний ясно показывают, что культура - это не разовый укол, а продолжающийся процесс, постоянно конструируемый и реконструируемый в ходе взаимодействия [см., например, Fine and Kleinman 1979; Cole 1979, гл. 1]. Она не только формирует тех, кто к ней принадлежит, но и сама также формируется ими, отчасти под воздействием их собственных стратегических замыслов.

Даже если экономисты (например, столь разные фигуры, как Харви Лайбенстайн и Гэри Беккер [Leibenstein 1976; Becker 1976]) принимают социальные отношения всерьез, они неизменно абстрагируются от истории этих отношений и их связи с другими отношениями, т.е. от их исторической и структурной укорененности. Межличностные связи описываются ими в предельно стилизованном, усредненном, «типичном» виде, лишенном всякого особенного содержания, истории или структурной позиции. Поведение акторов производно от их ролевой позиции и ролевого набора. В результате мы можем объяснить, как будут взаимодействовать друг с другом рабочие и мастера, мужья и жены, преступники и служители закона, однако изначально предполагается, что содержание их отношений ограничивается данными ролями и не имеет индивидуальных особенностей. Именно за это социологи-структуралисты и критикуют социологию Т. Парсонса: в его общей концептуальной схеме специфика индивидуальных отношений уходит на второй план, становится побочным явлением в сравнении с устойчивыми структурами нормативных ролевых предписаний, производными от основных ценностных ориентаций. В экономических моделях такой подход к социальным отношениям приводит к парадоксальному эффекту: решение представляется как атомизированное, даже если в его принятии задействовано более одного человека. Поскольку анализируемая группа индивидов (как правило, это диады, т.е. два взаимодействующих индивида, иногда - более крупные группы) отделена от своего социального контекста, то ее поведение обособлено от поведения других групп и от истории ее собственных отношений. Атомизация не исчезает, а просто переводится на другой уровень анализа - уровень диад или групп. Обратите внимание, каким образом пересоциализованное понятие используется для обоснования позиции о социальном действии как недосоциализованном, обособленном: акторы здесь ведут себя исключительно в соответствии со своими предписанными ролями.

Плодотворный анализ человеческого действия требует, чтобы мы избегали атомизации, подразумеваемой в теоретических крайностях пере- и недосоциализованного взглядов. Акторы не действуют и не принимают решения вне социального контекста, подобно разрозненным атомам они не подчиняются рабски предписаниям, определенным тем особым пересечением социальных позиций, которое им случилось занять. Вместо этого

природы и общества; представители деизма считали бога безличной первопричиной, отвергали религиозный фанатизм, отстаивали свободу вероисповедания. Для сравнения: теизм [от греч. theos - бог] - религиозно-философское учение, считающее бога абсолютной бесконечной личностью, стоящей над миром и человеком; в отличие от деизма рассматривает мир как осуществление божественного промысла // Словарь иностранных слов. http://az.don.sitek.net/cgi-bin/ivoc/ru/sis.pl. - Прим. перев.

8 Реж. Дон Фигель, киноверсия одноименной фантастической новеллы Джека Финна, 1956 г. - Прим. перев. 
их попытки целенаправленного действия укоренены в конкретных системах длящихся социальных отношений. В оставшейся части статьи я попытаюсь показать, как концепция укорененности изменяет наш теоретический и эмпирический подход к исследованию экономического поведения. Сначала я су̀жу предмет обсуждения до проблемы доверия и мошенничества в экономической жизни, а затем воспользуюсь дихотомией «рынки иерархии», чтобы показать возможности понятия укорененности для анализа этого вопроса 9 .

\section{Укорененность, доверие и мошенничество в экономической жизни}

Начиная примерно с 1970 г. экономисты с неослабевающим интересом обращаются к игнорируемым прежде проблемам доверия и мошенничества. Оливер Уильямсон отметил, что реальные экономические акторы не только преследуют свой эгоистический интерес, им свойствен также и «оппортунизм» - «следование интересу неблаговидными средствами; агенты, способные умело притворятся, осуществляют трансакции с большей выгодой для себя ${ }^{10}$. Экономический человек..., таким образом, - более сложное и менее прямолинейное существо, чем это предполагается в гипотезе о преследовании им своего эгоистического интереса» [Williamson 1975: 255].

Это указывает на одну особенность современной экономической теории: она исходит из того, что индивид преследует свои экономические интересы относительно джентльменскими способами. Эта концепция вновь поднимает гоббсовский вопрос о том, как люди преследуют собственные интересы преимущественно без насилия и обмана. Ведь в самом значении «эгоистического интереса» - и это было очевидно для Гоббса - нет ничего, что исключало бы применение силы или обмана.

Жизнеспособность этой посылки отчасти обязана действию на саморегулирующемся рынке конкуренции, которая, видимо, подавляет силу и обман. Однако эта идея также укоренена и в интеллектуальной истории дисциплины. В работе «Страсти и интересы» Альберт Хиршман показывает, что важное направление интеллектуальной истории периода от «Левиафана» до «Богатства народов» состояло в рассмотрении гоббсовской проблемы порядка через рассуждения о том, что одни человеческие мотивы держат под контролем другие, и, в частности, следование собственным экономическим интересам это, как правило, не проявление необузданной «страсти», а цивилизованное, спокойное занятие. Хотя и не обретя явного признания, эта идея получила широкое распространение,

9 Можно провести много параллелей между описываемыми мною «недосоциализованными» и «пересоциализованными» представлениями о действии и «атомистическим» и «нормативным» подходами Рональда Бёрта. Аналогично, предлагаемая здесь концепция укорененности как средний путь между пере- и недосоциализованными подходами, несомненно, имеет много общего со «структурным» подходом к действию Бёрта. Однако мой подход также во многом отличен от предлагаемого Бёртом. В двух словах это различие описать трудно, лучше всего сравнить данную статью с резюме его собственных взглядов [Burt 1982, гл. 9] и с формальными моделями, основанными на его концепции [Burt 1982, 1983]. Еще один близкий подход, уделяющий внимание влиянию социальных связей на целенаправленное действие, предлагает Питер Марсден, распространяющий теории коллективного действия и принятия решений Джеймса Коулмана на ситуации, где такие связи ведут к результатам, отличным от тех, что получились бы в случае совершенно изолированной ситуации [Marsden 1981, 1983].

10 Те, кто занимается социологией спорта, отметят, что это предположение уже высказывалось ранее Лео Дьюрокером, хотя и в несколько иной форме. 
что наглядно показывает, как недо- и пересоциализованные концепции взаимодополняют друг друга: обособленные акторы, действующие на конкурентных рынках, столь тщательно интериоризируют нормативные стандарты поведения, что в результате гарантируют порядок при осуществлении трансакций ${ }^{11}$.

В последнее время это убеждение несколько пошатнулось под влиянием все большего внимания к анализу на микроуровне несовершенных конкурентных рынков, характеризующихся небольшим количеством участников, неокупаемыми издержками и «специфическими вложениями человеческого капитала» [specific human capital investments]. В таких ситуациях нельзя уповать на то, что дисциплина, якобы имеющая место на конкурентных рынках, удержит их участников от обмана. Таким образом, мы вновь возвращаемся к классической проблеме: почему повседневная экономическая жизнь не переполнена проявлениями недоверия и мошенничества.

В экономической литературе мне видятся два фундаментальных ответа на этот вопрос, и я утверждаю, что один из них предполагает недосоциализованную, а другой пересоциализованную концепции человеческого действия. Рассуждения в недосоциализованном стиле свойственны главным образом новой институциональной экономике - не слишком четко определенному сообществу экономистов, заинтересованных в объяснении социальных институтов с неоклассических позиций [см., например, Furubotn and Pejovich 1972; Alchian and Demetz 1973; Lazear 1979; Rosen 1982; Williamson 1975, 1979, 1981; Williamson and Ouchi 1981]. В целом, все представители этого направления полагают, что социальные институты и образования [arrangements], прежде считавшиеся случайным результатом действия правовых, исторических, социальных и политических сил, правильнее рассматривать как способ эффективного решения определенных экономических проблем. Эти рассуждения близки к структурнофункционалистской социологии 1940-1960 гг., и значительная их часть не выдерживает проверки функционалистскими аргументами, предложенными Робертом Мертоном в 1947 г. Возьмем, к примеру, утверждение Эндрю Шоттера о том, что для понимания того или иного наблюдаемого нами экономического института требуется только, чтобы мы «вычислили эволюционную проблему, благодаря которой произошло его развитие. Для разрешения всякой эволюционной экономической проблемы необходим свой социальный институт» [Schotter 1981: 2].

Получается, что мошенничества удается избежать потому, что наличие разумных институциональных образований делает его слишком дорогостоящим. И сами эти образования, которые, как считалось прежде, не выполняют никакой экономической функции, сегодня рассматриваются как нечто, возникшее специально, чтобы препятствовать мошенничеству. Заметим, однако, что они не порождают доверие, а являются вместо этого его функциональным субститутом. В числе образований такого рода - сложные явные и неявные (скрытые) контракты [explicit and implicit contracts] [Okun 1981]. Они включают, в частности, задержку компенсационных выплат и принудительный выход на пенсию, которые, как считается, ослабляют стремления «уклониться» от работы [shirking] или распространять секретную информацию [Lazear 1979; Pakes and Nitzan 1982]), а также властные структуры, препятствующие появлению оппортунизма путем разрешения спорных вопросов в приказном порядке [Williamson 1975]. Недосоциализованность этих концепций заключается в том, что они не учитывают степень, в какой развитию мошенничества препятствуют межличностные отношения и сопряженные с ними обязательства, а не одни лишь институциональные образования. Подмена этих образований доверием в сущности ведет к гоббсовской ситуации, когда у всякого рационального индивида есть тот или иной стимул искать разумные пути обойти

11 Этим замечанием я обязан одному из анонимных рецензентов. 
эти образования. И трудно представить, что повседневная экономическая жизнь не наполнится еще более искусными попытками обмана.

По мнению других экономистов, мы должны допустить, что какая-то степень доверия все же имеет место, - ведь одни только институциональные образования не могут сдерживать насилие или обман. Тем не менее, источник доверия здесь по-прежнему неясен, и порою его объясняют существованием некоей «обобщенной морали» [generalized morality]. Например, Кеннет Эрроу предполагает, что «в ходе своей эволюции общество выработало негласные соглашения относительно определенного уважения к другим [людям], и эти соглашения оказались жизненно важными для общества или, по крайней мере, серьезно повлияли на эффективность его работы [Arrow 1974: 26; о происхождении «честности» см. также Akerlof 1983].

Ныне едва ли кто-то усомнится в существовании подобной обобщенной морали. Не будь ее, вы поостереглись бы давать служащему на автозаправочной станции банкноту в двадцать долларов, купив бензин на пять. Однако эта концепция пересоциализована, ибо предполагает общую автоматическую реакцию, хотя моральное действие в экономической жизни вряд ли автоматично и универсально (как это хорошо известно в случае с автозаправкой, где требуют точной сдачи после наступления темноты).

Рассмотрим ситуацию, когда обобщенная мораль, пожалуй, действительно имеет место: вообразим (надо сказать, не без труда) экономического человека, который, вопреки всякой экономической рациональности, оставляет чаевые в придорожном ресторане вдали от дома. Подобная трансакция несколько необычна по трем причинам: 1) ее участники не встречались прежде; 2) едва ли они встретятся снова; 3) информация о действиях хотя бы одного из них едва ли дойдет до кого-либо, с кем им доведется иметь дело в будущем. Я утверждаю, что только в таких ситуациях отсутствие силы и обмана можно объяснить существованием обобщенной морали. И даже здесь ее эффективность легко поставить под сомнение - стоит представить ситуацию, связанную с высокими издержками для ее участников.

В концепции укорененности вместо этого подчеркивается роль конкретных межличностных отношений и их структур (или «сетей») при производстве доверия и сдерживании мошенничества. Не секрет, что люди предпочитают иметь дело с индивидами, чья репутация им известна. Это подразумевает, что немногие готовы положиться на действие обобщенной морали или институциональных образований как защиту против бесчестности. Экономисты действительно показали, что одним из стимулов к избеганию обмана является угроза повредить своей репутации. Однако это недосоциализованное понимание репутации: она предстает как обобщенный товар, соотношение реальных попыток обмана с возможностями их совершения. На практике же мы довольствуемся подобной обобщенной информацией, только если нет ничего лучшего. А обычно мы стремимся получить более полную информацию. Слова знакомого, которому мы доверяем, о том, что он имел дело с таким-то индивидом и тот действительно не подвел, гораздо надежнее простого утверждения о том, что на такого-то, говорят, можно положиться. Еще лучше, если информация основана на собственном опыте взаимодействия с этим человеком в прошлом. Такая информация лучше по четырем причинам: 1) она дешева; 2) собственной информации мы доверяем более всего она самая полная, самая подробная, самая точная; 3) индивиды, с которыми у нас сложились длительные отношения, заинтересованы в том, чтобы мы им доверяли, ибо это позволяет рассчитывать на трансакции и в будущем; 4) и отвлекаясь от чисто экономических мотивов: продолжительные экономические отношения зачастую наполняются социальным содержанием, предполагающим особенно сильные ожидания доверия и воздержание от оппортунизма. 
Нам никогда не придет в голову усомниться в последнем утверждении в случае более тесных отношений, делающих поведение более предсказуемым и, значит, более свободным от опасений, которые осложняют общение между незнакомцами. Вдумайтесь, например, отчего при пожаре в театре все в панике устремляются к дверям, что приводит к столь печальным последствиям. Аналитики коллективного поведения долгое время считали это прототипом иррационального поведения. Однако Роджер Браун показывает, что, в сущности, это та же ситуация, что и в дилемме заключенного с числом участников $n$ [n-person prisoner's dilemma] [Brown 1965, гл. 14]. На самом деле каждый устремляющийся к двери действует совершенно рационально - ведь даже если он понимает, что лучше было бы всем пойти спокойно и по очереди, у него нет гарантии, что другие поступят именно так. Однако, обратите внимание, в 11-часовых новостях вы никогда не услышите, что при пожаре в таком-то доме члены семьи в панике давили друг друга. В семье не существует дилеммы заключенного, потому что каждый уверен, что на других можно положиться.

Очевидно, что в деловых отношениях степень доверия может различаться гораздо сильнее. Однако дилеммы заключенного здесь тем не менее удается избежать в силу существования личных отношений. И эта сила является свойством не самих участников трансакции, а конкретных отношений между ними. Стандартный экономический анализ игнорирует идентичность и прошлые отношения индивидов-участников трансакции, однако рациональные индивиды поступают иначе, полагаясь на свое знание этих отношений. Они заинтересованы в некоей общей репутации меньше, чем в том, можно ли ожидать от конкретного индивида честности в ведении дела именно $c$ ними. И в значительной степени эта позиция основана на том, был ли у участников трансакции или их знакомых удовлетворительный прошлый опыт сделок с этим индивидом. Данная модель прослеживается даже в ситуациях, на первый взгляд напоминающих классическую торговлю [higgling] в условиях конкурентного рынка, подобного описанному Клиффордом Гирцем марокканскому базару [Geertz 1979].

До сих пор я говорил о том, что доверие в хозяйственной жизни порождается не столько институциональными образованиями или обобщенной моралью, сколько социальными отношениями. Но тем самым я рискую попросту заменить одну разновидность оптимистического функционализма другой, - той, где структурой, выполняющей функцию поддержания порядка, являются сети отношений, а не мораль или институциональные образования. Подобной опасности можно избежать двумя путями. Во-первых, можно признать, что в качестве решения проблемы порядка концепция укорененности носит менее общий характер, чем всякое иное ее решение, поскольку сети социальных отношений пронизывают различные секторы хозяйственной жизни неравномерно и в различной степени. Тем самым они оставляют открытым путь недоверию, оппортунизму и беспорядку, которые при таком подходе никогда не исчезают полностью.

Во-вторых, можно настаивать на том, что хотя социальные отношения зачастую действительно являются необходимым условием возникновения доверия и доверительного поведения, тем не менее они их не гарантируют и могут даже порождать ситуации мошенничества и конфликта, причем более крупного масштаба, нежели те, что возникли бы в отсутствие социальных отношений. Тому есть три причины.

1. Доверие, порожденное личными отношениями, самим своим существованием открывает огромные возможности для мошенничества. Широко известно, что в личных отношениях «мы всегда делаем больно тому, кого любим»; что доверие человека к нам ставит его в ситуацию гораздо более уязвимую, чем если бы мы были посторонними людьми. (Возвращаясь к дилемме заключенного: знание того, что сообщник наверняка станет отрицать свое участие в преступлении, является для нас дополнительным рациональным мотивом сознаться в нем; при этом личные отношения, в условиях которых 
этой дилеммы не существует, могут быть менее симметричными, чем это полагает обманутая сторона.) Подобный элементарный факт социальной жизни лежит в основе злоупотребления «доверием» [«confidence» rackets], которое порою используется для симулирования определенных, подчас длительных отношений со скрытыми намерениями. В деловом мире некоторые преступления (например, растрата) просто невозможны там, где предварительно не были выстроены доверительные отношения, которые и дали возможность манипулировать счетами. Чем полнее доверие, тем бо́льшую выгоду приносит мошенничество. То, что такие случаи - статистически редкое явление, объясняется силой личных отношений и верой в репутацию; напротив, то, что они все же имеют место, причем довольно регулярно, показывает пределы воздействия этой силы.

2. К силе и обману наиболее эффективно прибегают группы людей. Структура этих групп требует определенного уровня внутреннего доверия (например, существует так называемая воровская честь), которое, как правило, вытекает из ранее сложившихся отношений. Сложные схемы взяток [kickbacks] и подтасовок [bid rigging] едва ли возможны для индивидов, действующих в одиночку. И когда подобная операция получает огласку, поражаешься, как удавалось держать ее в тайне, учитывая все множество посвященных в нее лиц. Усилия органов охраны правопорядка направлены на поиск возможности проникновения в сеть мошенников - т.е. на поиск индивида, чье признание потянет за собой признания остальных, которые, в свою очередь, укажут на следующих, пока, по принципу снежного кома, это не позволит выстроить полную картину мошенничества.

Таким образом, личные отношения могут породить и огромное доверие, и неслыханное мошенничество. Йорам Бен-Порат, следуя функционалистскому стилю новой институциональной экономики, обращает внимание на положительную сторону подобного явления. Он отмечает, что «длительность отношений может вызвать со стороны расчетливых, эгоистичных и даже беспринципных индивидов поведение, которое в противном случае можно было бы интерпретировать как неразумное или чисто альтруистическое. На торгах бриллиантами ценные камни переходят от одного владельца к другому, а сделка скрепляется лишь рукопожатием» [Ben-Porath 1980: 6]. Продолжая эту позитивную линию, я мог бы добавить, что подобная трансакция возможна отчасти потому, что она не отделена от других трансакций, а укоренена в сообществе торговцев бриллиантами, тесно связанных между собой и пристально наблюдающих за поведением друг друга. Подобно другим плотным сетям акторов, они продуцируют четко определенные стандарты поведения, которые легко контролируются стремительным распространением информации о случаях мошенничества. Однако такой уровень доверия порождает серьезные соблазны, и та же торговля бриллиантами не раз оказывалась жертвой воровства, совершаемого людьми своего круга. Эти преступления получили широкую огласку, в том числе знаменитые «убийства сотрудников CBS» ${ }^{12}$ в апреле 1982 г. В последнем случае владелец компании по обработке алмазов обманывал производственный концерн, выставляя счета за фиктивные продажи. Эта схема, разумеется, требовала участия и его бухгалтерии. Расследование вышло на одну из сотрудниц, и та дала показания. Тогда владелец компании заказал убийство предавшей его сотрудницы и ее помощника. Трое работников компании CBS, попытавшиеся прийти к ним на помощь, были также застрелены [Shenon 1984].

3. Степень беспорядка, вызываемого силой и обманом, во многом зависит от того, как структурирована сеть социальных отношений. Гоббс переоценил степень беспорядка, возникающего в рассматриваемом им атомизированном естественном состоянии, когда в отсутствие длительных социальных отношений можно ожидать возникновения только

12 Columbia Broadcasting System - Американская радиовещательная и телевизионная компания «Коламбиа бродкастинг систем». - Прим. перев. 
разрозненных конфликтов на уровне пар участников. Более серьезный и крупномасштабный беспорядок возможен в случае создания коалиций враждующими сторонами и определенных предварительных отношений между ними. Как правило, мы не ведем речь о «войне», пока в результате разного рода коалиций акторы не разделятся на два лагеря. Это происходит только тогда, когда межгрупповые связи недостаточно сильны, и у акторов, связанных с основными противоборствующими сторонами, отсутствует выраженный интерес в предупреждении конфликта. То же касается и делового мира: конфликты здесь относительно редки, однако возможны, если одна из сторон призовет в союзники достаточное количество других фирм. Порою так и происходит в случае попыток захвата компании или, напротив, стремления не допустить захвата.

Разумеется, беспорядок и мошенничество имеют место и при отсутствии социальных отношений. Их возможность подразумевается в моем предыдущем утверждении о том, что наличие социальных отношений препятствует развитию мошенничества. Однако распространенность мошенничества в полностью атомизированной социальной ситуации очень невелика, это лишь эпизодические, не связанные между собой, незначительные случаи. Поставленная Гоббсом проблема поистине непроста, однако, пытаясь разрешить еe при помощи смягчающего воздействия социальной структуры, мы тем самым предполагаем также и возможность нарушений более крупного характера, чем те, что случаются в «естественном состоянии».

Следовательно, в своем анализе конкретных моделей социальных отношений при изучении проблемы доверия и порядка в экономической жизни концепция укорененности оказывается примерно посредине между пересоциализованным подходом, предполагающим существование обобщенной морали, и недосоциализованным подходом, указывающим на безликие, институциональные образования. В отличие от обеих альтернатив (а также и от гоббсовской позиции) здесь не делаются предсказания обобщающего (и, значит, малоправдоподобного) характера относительно универсального порядка или беспорядка. Просто данная концепция исходит из того, что интересующие нас явления будут определяться конкретными характеристиками социальной структуры. $<\ldots>$

\section{Библиография}

Akerlof, George. Loyalty Filters, American Economic Review (1983). Vol. 73, No. 1. P. 54-63.

Alchian, Armen and Harold Demsetz. The Property Rights Paradigm, Journal of Economic History (March 1973). Vol. 33. P. 16-27.

Arrow, Kenneth. The Limits of Organization. N.Y.: Norton, 1974.

Baker, Wayne. Floor Trading and Crowd Dynamics, in: Adler, Patricia and Peter Adler (eds.) Social Dynamics of Financial Markets. Greenwich, Conn.: JAI, 1983.

Becker, Gary. The Economic Approach to Human Behavior. Chicago: University of Chicago Press, 1976.

Ben-Porath, Yoram. 1980. The F-Connection: Families, Friends and Firms in the Organization of Exchange, Population and Development Review (1980). Vol. 6, No. 1. P. 1-30.

Bowles, Samuel and Herbert Gintis. Schooling in Capitalist America. N.Y.: Basic Books, 1975.

Brown, Roger. Social Psychology. N.Y.: Free Press, 1965.

Burt, Ronald. Toward a Structural Theory of Action. N.Y.: Academic Press, 1982.

Burt, Ronald. Corporate Profits and Co-optation. N.Y.: Academic Press, 1983. 
Cole, Robert. Work, Mobility and Participation: A Comparative Study of American and Japanese Industry. Berkeley and Los Angeles: University of California Press, 1979.

Dalton, Melville. Men Who Manage. N.Y.: Wiley, 1959.

Doeringer, Peter and Michael Piore. Internal Markets and Manpower Analysis. Lexington, Mass.: Heath, 1971.

Duesenberry, James. Comment on "An Economic Analysis of Fertility", in: Demographic and Economic Change in Developed Countries, edited by the Universities National Bureau Committee for Economic Research. Princeton, N.J.: Princeton University Press, 1960.

Eccles, Robert. The Quasifirm in the Construction Industry, Journal of Economic Behavior and Organization (December 1981). Vol. 2. P. 335-357.

Eccles, Robert. A Synopsis of Transfer Pricing: An Analysis and Action Plan. Mimeographed. Cambridge, Mass.: Harvard Business School, 1982.

Eccles, Robert. Transfer Pricing, Fairness and Control. Working Paper no. HBS 83-167. Cambridge, Mass.: Harvard Business School. Reprinted in Harvard Business Review, 1983.

Feld, Scott. The Focused Organization of Social Ties, American Journal of Sociology (1981). Vol. 86, No. 5. P. 1015-35.

Fine, Gary and Sherryl Kleinman. Rethinking Subculture: An Interactionist Analysis, American Journal of Sociology (July 1979). Vol. 85. P. 1-20.

Furubotn, E. and Svetozar Pejovich. Property Rights and Economic Theory: A Survey of Recent Literature, Journal of Economic Literature (1972). Vol. 10, No. 3. P. 1137-62.

Geertz, Clifford. Suq: The Bazaar Economy in Sefrou, in: Geertz, C., H.Geertz and L.Rosen (eds.) Meaning and Order in Moroccan Society. N.Y.: Cambridge University Press, 1979. P. 123-225.

Granovetter, Mark. Getting a Job: A Study of Contacts and Careers. Cambridge, Mass.: Harvard University Press, 1974.

Granovetter, Mark. Toward a Sociological Theory of Income Differences, in: Berg, Ivar (ed.) Sociological Perspectives on Labor Markets. N.Y.: Academic Press, 1981. P. 11-47.

Granovetter, Mark. Labor Mobility, Internal Markets and Job-Matching: A Comparison of the Sociological and Economic Approaches. Mimeographed. 1983.

Granovetter, Mark. Small Is Bountiful: Labor Markets and Establishment Size". American Sociological Review (1984). Vol. 49, No. 3. P. 323-34.

Hirschman, Albert. The Passions and the Interests. Princeton, N.J.: Princeton University Press, 1977.

Hirschman, Albert. Rival Interpretations of Market Society: Civilizing, Destructive or Feeble? Journal of Economic Literature (1982), Vol. 20, No. 4. P. 1463-84.

Homans, George. The Human Group. N.Y.: Harcourt race \& Co., 1950.

Homans, George. Social Behavior. N.Y.: Harcourt Brace Jovanovich, 1974.

Lazear, Edward. Why Is There Mandatory Retirement? Journal of Political Economy (1979). Vol. 87, No. 6. P. 1261-84.

Leibenstein, Harvey. Beyond Economic Man. Cambridge, Mass.: Harvard University Press, 1976.

Liebow, Elliot. Tally's Corner. Boston: Little, Brown, 1966. 
Lincoln, James. Intra- (and Inter') Organizational Networks, in: Bacharach, S. (ed.) Research in the Sociology of Organizations, Vol. 1. Greenwich, Conn.: JAI, 1982. P. 1-38.

Lohr, Steve. When Money Doesn't Matter in Japan, New York Times (December 30, 1982).

Macaulay, Stewart. Non-Contractual Relations in Business: A Preliminary Study, American Sociological Review (1963). Vol. 28, No. 1. P. 55-67.

Marsden, Peter. Introducing Influence Processes into a System of Collective Decisions, American Journal of Sociology (May 1981). P.: 1203-35.

Marsden, Peter. Restricted Access in Networks and Models of Power, American Journal of Sociology (January 1983). Vol. 88. P. 686-17.

Merton, Robert. Manifest and Latent Functions, in: Social Theory and Social Structure. N.Y.: Free Press, 1947. P. 19-84.

Mintz, Beth and Michael Schwartz. The Power Structure of American Business. Chicago: University of Chicago Press, 1985.

North, D. and R.Thomas. The Rise of the Western World. Cambridge: Cambridge University Press, 1973.

Okun, Arthur. Prices and Quantities. Washington, D.C.: Brookings, 1981.

Pakes, Ariel, and S.Nitzan. "Optimum Contracts for Research Personnel, Research Employment and the Establishment of 'Rival' Enterprises". NBER Working Paper no 871. Cambridge, Mass.: National Bureau of Economic Research, 1982.

Parsons, Talcott. The Structure of Social Action. N.Y.: Macmillan, 1937.

Pfeffer, Jeffrey. Organizational Demography, in: Cummings, L.L. and B.Staw (eds.) Research in Organizational Behavior, Vol. 5. Greenwich, Conn.: JAI., 1983.

Phelps Brown, Ernst Henry. The Inequality of Pay. Berkeley: University of California Press, 1977.

Piore, Michael. Notes for a Theory of Labor Market Stratification, in: Edwards, R., M.Reich and D.Gordon (eds.) Labor Market Segmentation. Lexington, Mass.: Heath, 1975. P. 125-50.

Piore, Michael (ed.) Unemployment and Inflation. White Plains, N.Y.: Sharpe, 1979.

Polanyi, Karl. The Great Transformation. N.Y.: Holt, Rinehart, 1944.

Polanyi, Karl, C. Arensberg and H.Pearson. Trade and Market in the Early Empires. N.Y.: Free Press, 1957.

Popkin, Samuel. The Rational Peasant. Berkeley and Los Angeles: University of California Press, 1979.

Rosen, Sherwin. Authority, Control and the Distribution of Earnings, Bell Journal of Economics (1982). Vol. 13, No. 2. P. 311-23.

Samuelson, Paul. Foundations of Economic Analysis. Cambridge, Mass.: Harvard University Press, 1947.

Schneider, Harold. Economic Man: The Anthropology of Economics. N.Y.: Free Press, 1974.

Schotter, Andrew. The Economic Theory of Social Institutions. N.Y.: Cambridge University Press, 1981.

Scott, James. The Moral Economy of the Peasant. New Haven, Conn.: Yale University Press, 1976. 
Shenon, Phillip. Margolies Is Found Guilty of Murdering Two Women, in: New York Times (June 1, 1984).

Simon, Herbert. Administrative Behavior. Glencoe, Ill.: Free Press, 1957.

Smith, Adam. The Wealth of Nations. Edited by Andrew Skinner. Baltimore: Penguin, (1776) 1979.

Stearns, Linda. Corporate Dependency and the Structure of the Capital market: 1880-1980. $\mathrm{Ph}$. D. dissertation, State University of New York at Stony Brook, 1982.

Tompson, E.P. The Moral Economy of the English Crowd in the Eighteenth Century, Past and Present (February 1971). Vol. 50. P. 76-136.

Useem, Michael. The Social Organization of the American Business Elite and Participation of Corporation Directors in the Governance of American Institutions, American Sociological Review (1979). Vol. 44. P. 553-72.

Webster, Frederick and Yoram Wind. Organizational Buying Behavior. Englwood Cliffs, N.J.: Prentice-Hall, 1972.

White, Harrison C. Where Do markets Come From? American Journal of Sociology (November 1981). Vol. 87. P. 517-47.

Williamson, Oliver. Markets and Hierarchies. N.Y.: Free Press, 1975.

Williamson, Oliver. Transaction-Cost Economics: The Governance of Contractual Relations, Journal of Law and Economics (1979). Vol. 22, No. 2. P. 233-61.

Williamson, Oliver. The Economics of Organization: The Transaction Cost Approach, American Journal of Sociology (November 1981). Vol. 87. P. 548-77.

Williamson, Oliver and William Ouchi. Markets and Hierarchies and Visible Hand Perspectives, in: Van de Ven, Andrew and William Joyce (eds.) Perspectives on Organizational Design and Behavior. N.Y.: Wiley, 1981. P. 347-70.

Wrong, Dennis. The Oversocialized Conception of Man in Modern Sociology, American Sociological Review (1961). Vol. 26, No. 2. P. 183-93. 


\title{
Взгляд из регионов
}

$\boldsymbol{V} \boldsymbol{R}$ Мы вновь возвращаемся к проекту о стратегиях совладания и размещаем работу Е.С. Балабановой (Нижний Новгород). Предыдущие работы можно посмотреть в нашем журнале ${ }^{1}$.

\section{СТРАТЕГИИ СОВЛАДАНИЯ С ЖИЗНЕННЫМИ ТРУДНОСТЯМИ: САМОСТОЯТЕЛЬНОСТЬ ИЛИ ЗАВИСИМОСТЬ?}

\author{
Балабанова Евгения Сергеевна \\ канд. социол. наук, доцент кафедры общей социологии и социальной работы факультета \\ социальных наук Нижегородского государственного университета \\ Email: balhome@unn.ac.ru
}

Институциональные изменения в социальной и экономической сферах жизни современного российского общества предполагают расширение сферы индивидуальной свободы человека, пропорциональное расширению его сферы ответственности. Либерализация экономической деятельности, наряду с высвобождением социальноинновационных сил общества, также расширяет пространство социальных угроз, связанных с тем, что перестали быть гарантированными такие блага, как доход, занятость, многие ранее бесплатные социальные услуги.

Последнее обстоятельство означает, что осуществление независимых жизненных стратегий сегодня является не только добровольным выбором наиболее мобильных, активных и самостоятельных членов общества, но и требованием, налагаемым экономической реальностью на всех без исключения трудоспособных людей, включая и тех, кто не желает пользоваться предоставленной им свободой, предпочитая ее обмен на гарантированные жизненные блага.

Желание променять Свободу на Благо ${ }^{2}$, пожалуй, особенно ярко проявляется в ситуации кризиса, жизненной трудности, когда нарушается нормальная жизнедеятельность человека, когда с ним происходят события, угрожающие его текущему и будущему благополучию. В таких ситуациях, с одной стороны, у индивида сильны потребность во внешней поддержке, опоре, стремление переложить на кого-то свои проблемы. Именно в таких ситуациях активность людей нередко направлена на поиск чего-то стабильного, прочной опоры в виде религии, традиции, системы социальных гарантий. Поэтому можно говорить о социально-экономической зависимости многих людей, оказавшихся в ситуации жизненных трудностей. Она проявляется как реальное состояние (неспособность самостоятельно обеспечить себя средствами к существованию, пребывание под чьей-либо опекой) и как феномен сознания (ожидание внешней помощи в сфере жизнеобеспечения,

\footnotetext{
${ }^{1}$ См.: Демин А.Н. Возможности использования человеком индивидуальных и социальных ресурсов в ситуации отсутствия работы (2000. Т. 1, № 1); Петрова Л.Е. «Новые бедные» ученые: жизненные стратегии в условиях кризиса (2001. Т. 2, № 1); Радаев В.В. Работающие бедные: велик ли запас прочности? (2000. Т. 1, № 1).

${ }^{2}$ Об оппозиции Свободы и Блага в либеральной традиции см.: Bluhm, W.T. Theories of the Political System. Classics of Political Thought and Modern Political Analysis. Englewood Cliffs, N.J.: Prentice Hall, 1978; Хайек Ф.А. Индивидуализм: истинный и ложный / Ф.А. Хайек. Индивидуализм и экономический порядок. М., 2000. С. 41; Федотова В.Г. Россия в глобальном и внутреннем мире // Мир России, 2000. № 4. С. 28-29.
} 
осознание себя вправе эту помощь получать и готовность в связи с этим нести определенные издержки, ограничивающие личную свободу).

С другой стороны, подобные ситуации, напротив, актуализируют необходимость мобилизации собственных ресурсов индивида, и сама возможность справиться с жизненными трудностями зависит от того, насколько индивиду это удается, насколько он оказывается независимым в решении своих проблем (в данном случае под независимостью понимается решение своих проблем преимущественно самостоятельно, за счет собственных ресурсов, которые предлагаются обществу в процессе эквивалентного обмена деятельностью). Это особенно актуально в условиях несовершенной и неэффективной российской системы социальной защиты, а также макроэкономической нестабильности в современной России, когда не только отдельные индивиды, но и целые социальные группы оказываются в ситуации жизненных трудностей, таких, как потеря работы, дохода, вынужденный переезд и т.п.

Как фиксировать социально-экономическую зависимость в массовых социологических опросах? Насколько стратегии совладания, предпринимаемые людьми, оказавшимися в трудной жизненной ситуации, являются «самостоятельными» либо «зависимыми»? Чем характеризуются те и другие? Какие респонденты их реализуют? Наконец, какие стратегии - независимые или ориентированные на поиск внешней поддержки оказываются наиболее результативными? Попытка ответа на эти вопросы предпринята на основе анализа данных, собранных в ходе исследования «Совладающее поведение в посткоммунистической России: экономические и социальные стратегии андекласса», проведенного в 1998-2000 гг. под руководством В.В. Радаева ${ }^{3}$. Объектами исследования были стратегии совладания с жизненными трудностями трех групп респондентов вынужденных мигрантов, безработных и «работающих бедных» - работников депрессивных предприятий с длительными задержками заработной платы и низким уровнем оплаты труда.

\section{Качественные выводы в количественных исследованиях?}

Эта проблема является одним из самых серьезных ограничений количественных методов в социологических исследованиях. Между тем, в задаче исследовательского проекта «Совладающее поведение в посткоммунистической России» стояло как раз выявление стратегий совладания с трудностями, которые являются многомерными, включая в себя 1) непосредственно осуществляемые действия; 2) компонент планирования своей деятельности; 3) представление о должном, т.е. систему общих взглядов на жизнь и ценностных ориентаций.

С одной стороны, эта задача решается с применением «мягких» исследовательских методик, что и было продемонстрировано в ряде публикаций ${ }^{4}$. Действительно, данные интервью позволяют построить «типы стратегий», осуществляемых респондентами. Но

3 При финансовой поддержке Института «Открытое общество» (Фонд Сороса). Сбор эмпирических данных включал 2 серии неформализованных интервью и массовый опрос $(\mathrm{N}=806)$ среди трех групп респондентов - вынужденных мигрантов, безработных и «работающих бедных». Исследование проводилось в Москве, Нижнем Новгороде, Екатеринбурге, Краснодаре.

${ }^{4}$ См.: Балабанова E.C. Вынужденные мигранты: стратегии совладания с жизненными трудностями // Экономическая социология, 2000. Т. 1, №. 2 / www.ecsoc.msses.ru; Балабанова E.C. Типы стратегий совладания с жизненными трудностями / Кто и куда стремится вести Россию? Акторы макро-, мезо- и микроуровней современного трансформационного процесса. Под общ. ред. Т.И. Заславской. М.: Интерцентр, 2001. 
при этом неизбежно возникает потребность проверки исследовательских моделей с применением математического аппарата, а также ответа на вопросы «сколько?», «какие стратегии являются наиболее распространенными?», что в принципе недостижимо в традиции «понимающей» социологии.

Поэтому основной методологической сложностью в данном проекте стал поиск адекватных инструментов для выделения стратегий совладания с трудностями через призму зависимости/самостоятельности и сочетание качественных и количественных методов в рамках одного исследования. Это тот случай, когда не существует готовых переменных, на основе которых мы можем делать выводы о «зависимых» или «независимых» стратегиях, а значит, в анализе количественных данных недостаточно было простых и наиболее часто применяемых статистических методов - одномерных частотных распределений и кросстабуляций. Поставленные задачи можно было решить только с помощью методов многомерного анализа данных.

\section{Теоретические подходы к изучению социально-экономической зависимости}

Для того, чтобы зафиксировать то или иное явление в эмпирическом исследовании, исследователь должен, прежде всего, уяснить содержательное наполнение категории, с которой он работает. Решить задачу операционализации феномена социальноэкономической зависимости нам помог анализ проблематики зависимости и самостоятельности в различных интеллектуальных традициях. Выделим наиболее принципиальные положения, которые впоследствии будут трансформированы в систему индикаторов социально-экономической зависимости в эмпирическом исследовании.

Зависимость как состояние:

- получение субъектом X жизненно необходимых для него благ от субъекта Y, который является монопольным обладателем этих ресурсов

- асимметричный характер обмена ресурсами, то есть субъект X не просто получает необходимые ему ресурсы из безальтернативного источника, но и является неттореципиентом, не способным адекватно ответить на благодеяния $\mathrm{Y}^{6}$;

Зависимость как установка:

- готовность отказаться от Свободы во имя Блага, т.е. преобладание ценностей стабильности, защищенности над ценностями независимости и достижений ${ }^{7}$

- диффузия ответственности за решение своих проблем, т.е. ожидание помощи со стороны, неготовность проявлять активность в решении собственных проблем ${ }^{8}$;

${ }^{5}$ Schmidtz, D. and R. Googin. Social Welfare and Individual Responsibility. For and against. Cambridge: Cambridge University Press, 1998. P. 116-118; Poggi, G. Forms of Power. Cambridge: Polity Press, 2001. P. 131-132.

${ }^{6}$ Homans, G. Social Behaviour as Exchange, American Journal of Sociology (May 1958). Vol. 62; Homans, G. Social Behaviour: Its Elementary Forms. N.Y.: Harcourt, Brace and World, 1961; Blau P. Exchange and Power in Social Life. N.Y.: Wiley, 1964; Култылгин В.П. Концепция социального обмена в современной социологии // Социологические исследования, 1997. № 5; Коулман Дж. Капитал социальный и человеческий // Общественные науки и современность, 2001. № 3.

7 Достоевский Ф.М. Братья Карамазовы / Полн. собр. соч. в 30-ти т. Т. 14. С. 229-240; Достоевский Ф.М. Дневник писателя. 1873 / Достоевский Ф.М. Избранное. М.: Современник, 1989. С. 47, 136-137; Фромм Э. Бегство от свободы. М.: Прогресс, 1989. 
- экстернальный локус контроля респондентов, т.е. восприятие себя как пассивного объекта действия других людей и внешних обстоятельств ${ }^{9}$;

- представление о том, что государство обязано гарантировать гражданам приемлемый уровень жизни, заботиться о них, т.е. феномен «Ното Soveticus», сформированного в течение десятилетий государственного патернализма ${ }^{10}$;

- установки на традиционализм, недостижительские ценности ${ }^{11}$;

- заниженный уровень притязаний и ориентация на выживание в условиях экономической депривации, или «культура бедности» ${ }^{12}$.

Исследовательская гипотеза автора заключалась в том, что перечисленные выше характеристики являются атрибутами феномена социально-экономической зависимости, степень выраженности которых можно измерять. Кроме того, если эти индикаторы действительно меряют «одно и то же», между ними должна наблюдаться высокая степень корреляции, а в идеале они должны будут образовывать единый латентный фактор. Проверке этой гипотезы и посвящена данная статья.

\section{Переменные, фиксирующие «зависимые» стратегии}

Первым шагом анализа данных было создание индексов, отражающих интересующие нас аспекты совладания с трудностями. Исходя из выдвинутой гипотезы, на этом этапе мы создали 10 новых количественных переменных. Основным принципом их построения было объединение в каждую новую переменную исходных переменных, которые гипотетически «отвечали» за степень зависимости используемых респондентами стратегий. Соответственно, часть этих новых переменных отражала обладание респондентами ресурсов разного типа, часть - установки и ценности людей.

${ }^{8}$ Магун В.С. Потребности и психология социальной деятельности личности. Л.: Наука, 1983; Магун B.C. О взаимосвязях готовности человека к собственным усилиям и ожидаемой им помощью // Психологический журнал, 1991. Том 12. № 6.

${ }^{9}$ Бажин Е.Ф., Голынкина Е.А., Эткинд А.М. Метод исследования уровня субъективного контроля // Психологический журнал, 1984. Т. 5, № 3. С.152-153; Муздыбаев К. Психология ответственности. Л.: Наука, 1984. С. 45, 59-60, 88.

${ }^{10}$ Штомпка П. Социология социальных изменений. М.: Аспект Пресс, 1996; Штомпка П. Культурная травма в посткоммунистическом обществе // Социологические исследования, 2001. № 2; Советский простой человек: Опыт социального портрета на рубеже 90-х / Под ред. Ю. Левады. М., 1993; Левада Ю.А. Десять лет перемен в сознании человека // Общественные науки и современность, 1999. № 5; Левада Ю.А. От мнений к пониманию: Социологические очерки 1993-2000. М.: ВЦИОМ, 2001.

11 Магун В.C. Российские трудовые ценности в сравнительной перспективе / Социологические чтения. Вып. 2. М., 1997; Динамика ценностей населения реформируемой России / Отв. ред. Н.И. Лапин, Л.А. Беляева. М.: УРСС, 1996; Лапин Н.И. Кризисный социум в контексте социокультурных трансформаций // Мир России, 2000. № 3.

${ }^{12}$ Lewis, O. The Culture of Poverty, in: Ferman, L. et al. (eds.), Poverty in America. University of Michigan Press, 1965; Lewis, O. La Vida. N.Y.: Random House, 1968; Ярошенко С.C. Синдром бедности // Социологический журнал, 1994. № 2; Тихонова Н.Е. Факторы социальной стратификации в условиях перехода к рыночной экономике. М.: РОССПЭН, 1999. 
Для того, чтобы удостовериться, что выбранные нами переменные измеряют «одно и то же», была использована процедура анализа надежности (шкала Лайкерта). В случае достижения достаточно хороших результатов этого анализа мы считали возможным объединять выбранные нами переменные в одну путем создания индексов. В результате мы получили 10 новых переменных-индексов, чье содержательное наполнение выглядит следующим образом.

Первые четыре индекса характеризуют установки людей на самостоятельные либо зависимые стратегии. Их выяснение важно, поскольку установка является руководством к действию и включает в себя представления людей о себе самих, готовность действовать определенным образом и ценностное обоснование своих действий.

Индекс 1. Самоэффективность. Он образован следующими четырнадцатью исходными переменными (Alpha-коэффициент по шкале Лайкерта равен 0,81).

1. «Если я как следует постараюсь, то всегда найду решение даже сложных проблем».

2. «Если мне что-либо мешает, то я все же нахожу пути достижения своей цели».

3. «Если я приложу достаточно усилий, то смогу справиться с большинством проблем».

4. «При непредвиденно возникающих трудностях я верю, что смогу с ними справиться».

5. «Я могу что-либо придумать даже в безвыходных, на первый взгляд, ситуациях».

6. «Я готов к любым трудностям, поскольку полагаюсь на собственные способности».

7. «Если передо мной встает какая-либо проблема, то я обычно нахожу несколько вариантов ее решения».

8. «Я обычно способен держать ситуацию под контролем».

9. «В неожиданных ситуациях я всегда знаю, как я должен себя вести».

10. «Мне довольно просто удается достичь своих целей».

11. Жизненная ценность: «самостоятельность, независимость».

12. Жизненная ценность: «уверенность в себе, в своих силах».

13. Жизненная ценность: «активная, деятельная жизнь».

14. Изменение уверенности в своих возможностях в результате трудной жизненной ситуации.

Достаточно высокое значение Alpha-коэффициента показывает, что респонденты обычно являются последовательными, либо субъективно оценивая себя как «эффективных» людей, которым подвластны происходящие с ними события, либо, напротив, они тотально отрицая свою способность самостоятельно справиться с возникающими проблемами. Показательно, что с блоком вопросов по самоэффективности (который практически целиком вошел в новую переменную) тесно связаны ответы респондентов об их приверженности ценностям независимости, уверенности в себе и активной жизни. Кроме того, мы видим, что для людей, оценивающих себя как «авторов по отношению к своей жизни» ${ }^{13}$, трудная жизненная ситуация будет, скорее всего, «испытанием на прочность», в результате которой их уверенность в собственных силах повышается.

Поскольку анализ надежности выявил высокую степень зависимости переменных, принадлежащих к однотипной - интервальной - шкале, новая переменная «Самоэффективность» была создана в результате факторизации методом главных компонент с включением 14 вышеупомянутых переменных, и значение первой главной компоненты было выбрано в качестве индекса.

13 Осницкий А.К., Чуйкова Т.C. Саморегуляция активности субъекта в ситуации потери работы // Вопросы психологии, 1999. № 1. С. 96. 
Индекс 2. Недостижительские трудовые ценности. В него вошли 11 исходных переменных (Alpha-коэффициент по шкале Лайкерта равен 0,49).

1. Хорошие условия труда.

2. Приятная атмосфера в коллективе.

3. Удобный режим работы.

4. Полезность для общества.

5. Интересная работа.

6. Близость от дома.

7. Стабильная оплата.

8. Возможность пользоваться льготами.

9. Соответствие специальности.

10. Жизненная ценность: «личная защищенность».

11. Жизненная ценность: «стабильность жизни».

Существует большой пласт литературы, например, работы В.С. Магуна, посвященные изучению ценностей с точки зрения того, насколько они ориентируют респондентов на достижения. В частности, в этих работах показывается, что в сравнительных исследованиях российские респонденты приписывают более высокие ранги именно недостижительским трудовым ценностям, связанным с возможностью не работать. Хотя, как отмечается, в последние 5-7 лет в данной сфере произошли существенные сдвиги, являющиеся несколько парадоксальными в том плане, что повысилась значимость взаимоисключающих ценностей («гарантии против возможностей»), - наряду со стремлением максимизировать вознаграждения за работу выросло и требование стабильности работы и доходов ${ }^{14}$.

Как видим, в одном ряду с недостижительскими ценностями «советского простого человека» находятся также и ценности стабильности и защищенности - верные признаки патерналистских ориентаций.

Для образования этой новой переменной мы также использовали процедуру факторизации методом главных компонент.

Индекс 3. «Активные» выводы из трудной жсизненной ситуации. Сюда вошли исходные переменные, отражающие выводы респондентов о необходимости активизации своей деятельности, к которым они приходят в процессе осмысления причин своих трудностей, успехов и неудач в их преодолении. Коэффициент связи этих переменных по шкале Лайкерта составляет 0,62 .

1. Активнее искать работу.

2. Поменять место работы.

3. Обучаться новым специальностям, приобретать новые профессиональные навыки.

4. Открыть собственное дело.

5. Пытаться зарабатывать любыми способами.

6. Более уверенно себя вести, учиться подавать себя.

7. Надеяться, прежде всего, на себя.

8. Использовать любые шансы, предоставляемые жизнью.

9. Быть более настойчивым в реализации своих целей.

10. Стараться просчитывать возможные последствия своих решений.

${ }^{14}$ См., например: Магун В.С. Об изменениях трудовых ценностей российского населения / Куда идет Россия? Власть, общество, личность. Под общ. ред. Т.И. Заславской. М.: Интерцентр, 2000. 
Исходные переменные принадлежат к дихотомической шкале, поэтому для их объединения использовалась процедура создания индекса - его значение являлось суммой положительных ответов на вышеперечисленные вопросы.

Индекс 4. «Пассивные» выводы из трудной жизненной ситуащии. В противоположность предыдущей, эта переменная создана из отмеченных респондентами выводов о необходимости искать поддержку извне, приспосабливаться, невозможности что-либо изменить и т.п., к которым они пришли в трудной жизненной ситуации. Alphaкоэффициент по шкале Лайкерта равен 0,63.

1. Откладывать деньги на «черный день».

2. Экономить, более рационально вести бюджет.

3. Уделять больше времени и сил своей семье.

4. Активнее налаживать нужные связи с людьми.

5. Больше заботиться о своем здоровье.

6. Активнее участвовать в общественной, политической жизни.

7. Лучше знать российские законы.

8. Настойчивее требовать то, что тебе положено по закону.

9. Не быть столь требовательным к работе, условиям жизни, окружающим.

10. Терпеть испытания и лишения.

11. Стараться не обращать внимания на трудности.

12. Приспосабливаться к обстоятельствам людям.

Следующая группа индексов отражает наличие у индивидов ресурсов разного типа, которые, как предполагается, во-первых, отражают степень независимости индивида, и, во-вторых, влияют на выбор им определенных стратегий поведения в ситуации жизненных трудностей. Помимо приведенной выше аргументации анализа ресурсов как фактора зависимости/независимости, отметим, что ресурсный анализ сам по себе сегодня является продуктивным для понимания процессов в современном российском обществе на макро- и микроуровне ${ }^{15}$.

Показательно, что, по сути, эти индексы характеризуют не наличие, а отсутствие ресурсов, так как вопросы анкеты для респондентов в трудной жизненной ситуации были сфокусированы, прежде всего, на выявлении проблем людей.

Индекс 5. Стрессированность. Для создания этого индекса была также использована факторизация. Она образована следующими исходными количественными переменными (Alpha-коэффициент по шкале Лайкерта равен 0,58).

1. «Я часто ощущаю нервное напряжение».

2. «Моя повседневная деятельность вызывает большое напряжение».

3. «К концу дня я совершенно истощен физически и психически».

4. «Общаясь с людьми, я часто ощущаю нервное напряжение».

5. «Пожалуй, я человек нервный».

6. «В моей семье часто возникают напряженные отношения».

7. Жизненная ценность: «стабильность жизни».

8. Жизненная ценность: «материальная обеспеченность».

9. Жизненная ценность: «личная защищенность».

15 Ядов В.А. Социальный ресурс индивидов и групп как их капитал: возможность применения универсальной методологии исследования реального расслоения в российском обществе / Кто и куда стремится вести Россию?.. Акторы макро-, мезо- и микроуровней современного трансформационного процесса. 
10. Изменение уверенности в своих возможностях в результате трудной жизненной ситуации (отрицательная корреляция).

11. Изменение уверенности в завтрашнем дне в результате трудной жизненной ситуации (отрицательная коррелящия).

12. Изменение оценки своей полезности для общества в результате трудной жизненной ситуации (отрицательная корреляция).

На наш взгляд, этот индекс иллюстрирует то, насколько индивид является психологически «слабым» или «сильным». Средняя степень корреляции этих переменных показывает, что ценностям стабильности и защищенности, скорее всего, будут привержены слабые люди с высокой степенью стрессированности, оценивающие свое психологическое самочувствие, скорее, как неблагополучное. Высокое значение данной переменной также будет свидетельствовать о том, что в ситуации жизненной трудности психологически слабые люди чаще «ломаются», что выражается в общем снижении самооценки и веры в свои силы.

Индекс 6. Здоровье и психологическая устойчивость. Образован десятью исходными переменными (Alpha-коэффициент по шкале Лайкерта равен 0,47).

1. Наличие крепкого здоровья.

2. Изменение состояния здоровья в период трудной жизненной ситуации.

3. Проблема - ухудшение здоровья (Вашего или Ваших близких).

4. Проблема: неуверенность в завтрашнем дне.

5. Проблема: зависимость от внешних обстоятельств.

6. Проблема: неумение ориентироваться в ситуации.

7. Проблема: чувство бесполезности для людей и общества.

8. «Я очень беспокоюсь о своей работе».

9. Причина неудач в поиске работы: неподходящий возраст.

10. Причина неудач в поиске работы: плохое здоровье.

Индекс здоровья и психологической устойчивости высчитывался из суммирования перекодированных значений переменных, где показателям, характеризующим наличие таких ресурсов, приписывалось положительное значение, а показателям, отражающим проблемы, связанные с отсутствием таких ресурсов, - отрицательное. Как видим, людям, отмечающим, что у них есть проблемы со здоровьем, свойственна повышенная тревожность и неуверенность в собственных силах.

Индекс 7. Социальные ресурсы. Хорошо известно, что в условиях современного российского рынка большую роль играют персонифицированные отношения, связи личного типа. В то же время семейные обстоятельства и неблагоприятная структура домохозяйства (например, большая иждивенческая нагрузка, наличие больных) усугубляют ситуацию жизненных трудностей. Новая шкала «Социальные ресурсы» образована 12 исходными переменными (Alpha-коэффициент по шкале Лайкерта равен $0,42)$.

1. Наличие близких друзей в настоящее время.

2. Наличие родных, живущих поблизости.

3. Изменение моральной помощи близких в ситуации жизненной трудности.

4. Проблема: отсутствие родных и близких рядом.

5. Проблема: нехватка общения с друзьями и коллегами.

6. Проблема: напряженные отношения в семье.

7. Проблема: плохое отношение окружающих к Вам, Вашей семье. 
8. Причина трудностей: семейные обстоятельства (болезни, смерти, рождения детей).

9. Получение вещей от друзей в качестве безвозмездной помощи.

10. Использовали способ поиска работы: обращение к друзьям, знакомым.

11. Причина неудач в поиске работы: «нет связей, блата».

12. Причина неудач в поиске работы: «необходимость ухаживать за детьми, родственниками».

Индекс социальных ресурсов высчитывался из суммирования перекодированных значений переменных, где показателям, характеризующим наличие таких ресурсов, приписывалось положительное значение, а показателям, отражающим проблемы, связанные с отсутствием таких ресурсов, - отрицательное.

Индекс 8. Имущественные ресурсы. Наличие такого ресурса, вероятно, само по себе не оказывает влияния на выбор той или иной стратегии, однако имущественная обеспеченность обычно тесно связана с материальным благополучием респондентов. Переменная образована 10 исходными переменными, отражающими обеспеченность следующими товарами длительного пользования (Alpha-коэффициент по шкале Лайкерта составляет 0,67$)$.

1. Цветной телевизор.

2. Холодильник.

3. Стиральная машина.

4. Видеомагнитофон.

5. Микроволновая печь.

6. Персональный компьютер.

7. Мебельный гарнитур.

8. Автомобиль.

9. Гараж.

10. Дача, летний дом.

Индекс имущественных ресурсов был получен суммированием положительных ответов на вопрос о наличии тех или иных предметов длительного пользования в домохозяйствах респондентов.

Индекс 9. Активность в поиске работьл. Это единственная новая переменная, характеризующая собственно независимые действия респондентов. Она образована 10 исходными переменными (Alpha-коэффициент по шкале Лайкерта равен 0,79).

1. Изменение числа рабочих мест.

2. Наличие приработков.

3. Изменение уровня оплачиваемой занятости.

4. Изменение профессиональной квалификации.

5. Регулярность приработков.

6. Способ поиска работы: по объявлениям о вакансиях.

7. Способ поиска работы: давали объявления сами.

8. Способ поиска работы: обращались в частные агентства по подбору кадров.

9. Способ поиска работы: обращались в районный центр занятости.

10. Способ поиска работы: обращались к друзьям, знакомым.

Индекс также высчитывался путем суммирования перекодированных значений переменных. 
Индекс 10. Получение помощи от разных субъектов. Он образован путем суммирования случаев получения разных видов помощи (денежной, натуральной, услугами, моральной поддержки) от разных субъектов - родственников, друзей, знакомых, работодателей, государства, общественных организаций. Предполагалось, что высокие значения этого индекса должны будут свидетельствовать об «иждивенческой» стратегии респондента.

\section{Взаимосвязь индексов}

После выделения 10 новых переменных-индексов была поставлена задача выяснения их взаимозависимости и проверки возможности дальнейшего перехода в пространство еще меньшего количества факторов. 10 индексов, которые мы создали и которые, по нашему предположению, должны были отражать установки и ресурсы респондентов, являются количественными переменными. Следовательно, к ним могла быть применена единая процедура многомерного анализа. На следующем этапе мы добавили к ним переменные среднедушевого дохода в домохозяйствах, оценку по 9-балльной шкале своего социального статуса, а также переменную субъективной оценки своего материального положения, которые сами по себе оказывали значительное воздействие на многие переменные анкеты и не нуждались в предварительной индексации.

В результате применения процедуры факторизации методом главных компонент и поиска оптимального представления данных мы выделили пять факторов. Объясненная дисперсия равна 61\%. Факторные нагрузки после вращения методом Varimax выглядят следующим образом.

Таблица 1. Факторы и факторные нагрузки.

\begin{tabular}{|c|c|c|c|c|c|}
\hline \multirow[b]{2}{*}{ Индексы } & \multicolumn{5}{|c|}{ Факторы и факторные нагрузки } \\
\hline & 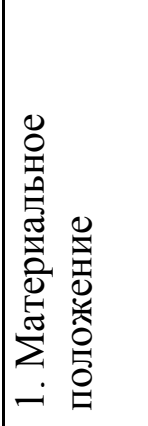 & 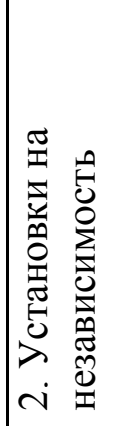 & 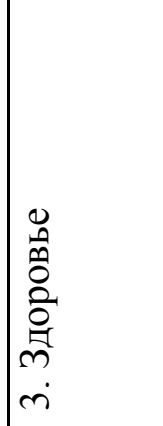 & 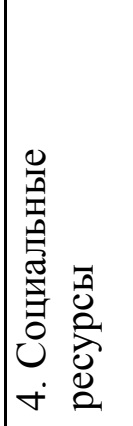 & 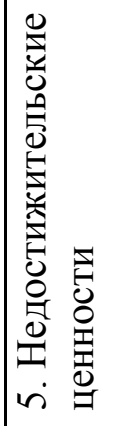 \\
\hline Имущественные ресурсы & 0,736 & & & & \\
\hline Материальное положение семьи & 0,713 & & & & \\
\hline Социальный слой & 0,585 & & 0,404 & & \\
\hline Душевой доход & 0,541 & & & & \\
\hline Активные выводы из ТЖС & & 0,816 & & & \\
\hline Самоэффективность & & 0,595 & & & \\
\hline Пассивные выводы из ТЖС & & 0,576 & & & 0,575 \\
\hline Активность в поиске работы & & 0,564 & & & $-0,428$ \\
\hline Здоровье & & & 0,818 & & \\
\hline Стрессированность & & & $-0,792$ & & \\
\hline Получение помощи от разных субъектов & & & & 0,810 & \\
\hline Социальные ресурсы & 0,394 & & & 0,676 & \\
\hline Недостижительские трудовые ценности & & & & & 0,652 \\
\hline
\end{tabular}


Как видно из таблицы, мы перешли в пространство пяти факторов, тем самым значительно облегчив себе дальнейшую интерпретацию материала. Выяснение взаимосвязи новых переменных позволяет нам сделать следующие выводы.

Фактор 1. Материальное положение. Сюда вошли «объективные» показатели материального положения, имущественного достатка и душевого дохода респондентов, изменение которых в одном направлении было предсказуемым. С повышением дохода, имущественной обеспеченности и субъективной оценки материального положения повышается и социальный слой, к которому относят себя респонденты. Интересен тот факт, что из показателей обладания ресурсами только социальные ресурсы демонстрируют степень корреляции с данным фактором, превышающую 0,3. T.е. наиболее благополучные в экономическом плане респонденты, скорее всего, будут иметь и развитую «сеть безопасности». Любопытно, что в этот фактор не вошли переменные, характеризующие установки респондентов на самостоятельность либо зависимость.

Фактор 2. Установки на независимость. Факторообразующей (имеющей наибольшую степень корреляции с данным фактором) здесь является переменная «Активные выводы из трудной жизненной ситуации», в одном направлении с которой изменяются переменные «Самоэффективность», «Активность в поиске работы» и... «Пассивные выводы из трудной жизненной ситуации». Последнее весьма трудно поддается объяснению наиболее вероятным кажется предположение, что само разбиение выводов, которые делают респонденты, на «активные» и «пассивные» является некорректным, поскольку мало дифференцирует респондентов в плане трудовой активности и самоэффективности. Вероятно, в действительности в одном направлении с реально осуществляемыми шагами в поиске работы находится само количество выводов, которые респонденты делают, т.е. степень когнитивной проработанности своих действий.

Фактор 3. Здоровье. Из таблицы очевидна большая вероятность того, что респонденты, обладающие ресурсом «Здоровье» (а точнее, не отмечающие у себя проблем со здоровьем), будут демонстрировать самый низкий уровень стрессированности. Из других показателей, вошедших в данный фактор, выделилась переменная социального слоя: респонденты, не имеющие проблем со здоровьем, склонны ставить себя на более высокие ступени социальной лестницы.

Фактор 4. Социальные ресурсы. Высокая степень корреляции с этим фактором индексовпеременных «Социальные ресурсы» и «Получение помощи от разных субъектов» означает, что наличие у респондентов близких, родных, друзей, хорошие отношения с ними, прежде всего, будут определять количество источников помощи и поддержки, к которым может прибегнуть респондент в трудной жизненной ситуации.

Фактор 5. Недостижительские иенности. Это наиболее размытый фактор, где нет переменных, демонстрирующих высокую степень корреляции с ним. Он лишь указывает на среднюю степень вероятности того, что люди, исповедующие трудовые ценности «простого советского человека», будут отличаться большей выраженностью «пассивных» выводов из трудной жизненной ситуации (терпеть, приспосабливаться, искать компенсации своим потерям) и что они будут демонстрировать меньшую активность в поиске работы.

\section{Типы респондентов и их стратегий}

Приведенные выше результаты выяснения взаимозависимости переменных позволяют нам понять внутреннюю структуру изучаемого явления социально-экономической зависимости. Фактически они продемонстрировали нам, что разные виды ресурсов, определяющих степень зависимости/самостоятельности респондентов, «укладываются» в 
пять факторов: материальные, психологические, социальные ресурсы, ресурс здоровья и ресурс ориентации на достижения (с отрицательным значением). Теперь нам предстоит ответить на вопрос: каким образом наши респонденты - люди в трудной жизненной ситуации - размещены в пространстве этих пяти факторов?

Поэтому следующим этапом нашего анализа стало выявление групп респондентов на основе значений этих факторов. Был проведен кластерный анализ методом $k$-средних, и путем подбора с целью оптимального представления данных были выделены пять кластеров - внутренне однородных групп респондентов.

Табл. 2. Объем и координаты кластерных центров в факторном пространстве.

\begin{tabular}{|c|c|c|c|c|c|c|}
\hline \multirow[b]{2}{*}{ Кластер } & \multirow[b]{2}{*}{ 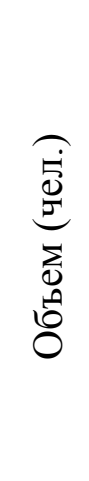 } & \multicolumn{5}{|c|}{ Значения факторов } \\
\hline & & 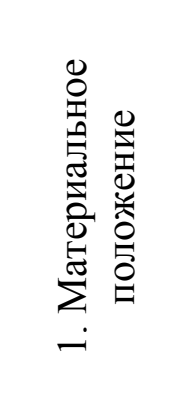 & 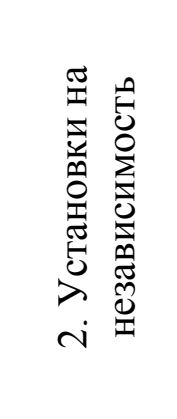 & 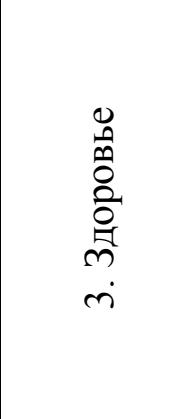 & 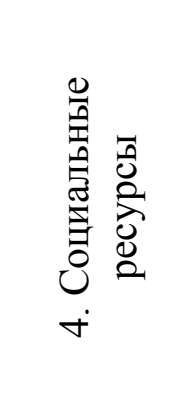 & 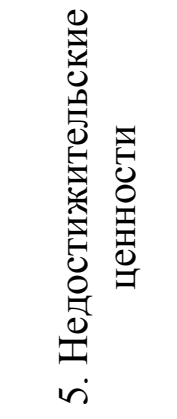 \\
\hline 1. «Исключенные» & 109 & $-1,23582$ & $-0,03580$ & -040863 & $-0,93408$ & $-0,24309$ \\
\hline 2. «Традиционалисты» & 180 & 0,18736 & 0,18391 & $-0,33412$ & 0,02444 & 1,09052 \\
\hline $\begin{array}{l}\text { 3. Получатели соц. } \\
\text { поддержки }\end{array}$ & 121 & $-0,46782$ & $-0,14542$ & $-0,32662$ & 1,29926 & $-0,53463$ \\
\hline $\begin{array}{l}\text { 4. «Плывущие по } \\
\text { течению» }\end{array}$ & 177 & 0,21883 & $-0,60527$ & 0,90285 & $-0,08198$ & $-0,07467$ \\
\hline 5. «Независимые» & 122 & 0,97421 & 0,78301 & $-0,12789$ & $-0,37118$ & $-0,75319$ \\
\hline
\end{tabular}

Кластер 1. «Исключенные». У этой группы респондентов самые низкие значения факторов «Материальное положение», «Здоровье» и «Социальные ресурсы». Первый вывод, который напрашивается в данной ситуации, - это то, что плохое здоровье и отсутствие «связей» непосредственно связаны с низким социальным статусом, низким доходом и плохой имущественной обеспеченностью. Причем влияние этих «объективных» факторов на бедность гораздо сильнее социально-психологических факторов независимости и ориентированности на достижения - по этим показателям данная группа занимает срединное положение.

Кто же эти «исключенные»? 71\% респондентов в данной группе - вынужденные мигранты. Их средний душевой доход действительно вдвое меньше среднего по выборке (900 руб. при среднем 1800 руб. ${ }^{16}$ ). Специфика ситуации вынужденных мигрантов, составивших костяк кластера, заключается в крайне низкой имущественной обеспеченности (из списка товаров длительного пользования, включающего 10 наименований, они владеют в среднем менее чем полутора предметами - обычно это цветной телевизор, холодильник или стиральная машина). Обеспеченность недвижимостью в этой группе практически нулевая. У $80 \%$ нет личного подсобного хозяйства, а значит, и возможности альтернативных зарплатным источников жизнеобеспечения. 74\% отметили отсутствие нормального жилья. 77\% оценили свое

16 Низкие значения доходов не должны удивлять читателя: напомним, что опрос проводился летом 1999 г. 
материальное положение как «Еле сводим концы с концами, часто не хватает денег на необходимые продукты питания».

Такое тяжелое материальное положение обусловлено как значительными расходами, понесенными мигрантами при переезде, так и их невключенностью в рынок труда. Проблема отсутствия (подходящей) работы отражается в частых попытках найти работу, обеспокоенности по поводу невозможности использовать свое образование и квалификацию, готовности взяться за любую работу. Признак неблагополучия их домохозяйств - это также структура доходов, в которой самый низкий по выборке удельный вес заработной платы (в среднем 45\%) и самый большой - социальных выплат пенсий, пособий и стипендий (25\%). Эта группа является «рекордсменом» по самой большой средней сумме долга, который они имеют.

Данная группа представляет собой и пример «потери первичной интеграции» - выпадения из социальных сетей. У них самая сложная ситуация в плане получения помощи от кого бы то ни было - в среднем отмечено менее 2 видов получения помощи из возможных 28 , причем это, как правило, не материальная помощь, а советы, информация, моральная поддержка от родных или друзей. 66\% отметили, что совсем не получают материальной помощи от близких, $38 \%$ не получают также и моральной поддержки. В этой группе больше всего респондентов отметили проблему отсутствия родных и близких рядом, нехватку общения, плохое отношение со стороны окружающих к ним и их семьям. Причем в этом кластере семья является не столько фактором помощи, сколько источником трудностей. Так, у трети респондентов причиной их проблем являются «семейные обстоятельства» (болезни, смерти, рождения детей).

Именно положение вне рынка труда и занятости и разрыв социальной сети отмечаются, в частности, французскими социологами как два важнейших фактора «риска исключения», которые сочетаются и взаимоусиливаются. Например, Р. Кастел объясняет феномен нисходящей мобильности все возрастающей доли населения потерей социальной интеграции по двум осям - работы и семейных отношений. С. Погам оперирует понятием «социальной дисквалификации», В. де Голейяк и И. Леонетти - «социальной сепарации» ${ }^{17}$. Концепция социального исключения, напомним, рассматривает бедность не как «состояние», а как накопление неблагоприятных жизненных обстоятельств, для которого характерна «множественность» проблем, накаливающихся подобно снежному кому (занятость, жилье, здоровье, социальная изоляция).

Чувство исключенности проявляется и в самом плохом по выборке социальнопсихологическом самочувствии этой группы. Известно, что феномен «ухода в себя» безработных был отмечен еще в исследованиях П. Лазарсфельда в 1930-е гг. в Австрии. Спустя 60 лет исследователи получают те же результаты. Нестабильность занятости повышает вероятность если не полной социальной изоляции, то спада социального участия. Позитивные корреляции отмечаются также с ухудшением состояния здоровья ${ }^{18}$. В нашем случае для трех четвертей из них характерно острое переживание своей ситуации, частое нервное напряжение, половина отмечают, что физически и психологически истощены к концу дня, $42 \%$ отметили напряженные отношения в своей семье. $73 \%$ отмечают уменьшение веры в себя, собственные возможности в результате трудной жизненной ситуации, 67\% - увеличение чувства зависимости от внешних обстоятельств.

${ }^{17}$ Claude, M. French Review Article: The Debate in France over «Social Exclusion», Social Policy \& Administration (December 1996). Vol. 30. No. 4. P. 382, 386, 388.

${ }^{18}$ Paugam, S. Poverty and Social Disqualification: a Comparative Analysis of Cumulative Social Disadvantage in Europe, Journal of European Social Policy (1996). Vol. 6. No. 4. P. 288296. 
Как мы отмечали выше, с высоким значением стрессированности связано плохое состояние здоровья. Действительно, отсутствие у себя в настоящий момент здоровья отметили $68 \%$ респондентов. У $62 \%$ оно ухудшилось в результате переезда, потери работы или доходов.

Картину обделенности ресурсами данной группы дополняет самый низкий образовательный уровень. $35 \%$ в данной группе имеют начальное и среднее общее образование.

$40 \%$ респондентов в данной группе отмечают увеличение объема своего свободного времени в период возникновения жизненной трудности. Памятуя, что почти три четверти этой группы составляют вынужденные мигранты, мы можем сказать, что в данной ситуации свободное время - не ресурс, а, скорее, признак неблагополучия ${ }^{19}$.

Способы выхода из сложившейся ситуации в этом кластере сложно назвать «стратегиями», скорее, они представляют собой «хаотичный поиск» ${ }^{20}$. Половина респондентов «не знают, что предпринять» для решения своих проблем. Их действия - это регулярные поиски работы (треть согласна на «любую»), также в этом кластере самая большая доля тех, что пытается получить помощь в государственных органах и общественных организациях. Состояние депрессии, напряжения и подавленности, характерное для данной группы, в свою очередь, отрицательно влияет на возможность выгодно «подать себя», творчески подойти к решению проблем и обрекает респондентов, по сути, на пассивные формы совладания с материальными трудностями: отстраненное принятие ситуации; ожидание какого-то события или чуда; бесплодное мечтание; смирение и бездействие; стойкое перенесение трудностей; жесткая экономия, отказ от потребления и самообслуживание членов семьи; избегание общения либо обвинение и поиск виновных. К. Муздыбаев высказывает мысль, что неэффективные формы поведения «запрограммированы» в самой бедности ${ }^{21}$.

Как видим, эта трудная жизненная ситуация оказалась для данной группы респондентов, прежде всего, цепью невосполнимых потерь. Объективно сложная ситуация, отсутствие источников получения помощи и чувство беспомощности от повторяющихся неудач способствуют интенсивной нисходящей мобильности и консервации трудностей. Между тем, исследователи отмечают тесную связь между длительным ухудшением условий жизни и существенным снижением у людей уровня социальных потребностей, притязаний и активности. Т.е. действует так называемый механизм снижения потребностей механизм регресса, приводящий к люмпенизации части населения ${ }^{22}$.

19 По этому поводу приведем размышления Э.М. Ремарка: «Какие, собственно, у эмигранта проблемы? Голод, жилье и время, которое некуда девать - ведь работать ему запрещено. Голод и забота о крыше над головой - вот два смертельных врага. С ними он должен бороться. Но время... Огромное, пустое, бесполезно уходящее время; этот притаившийся враг разъедает и подтачивает энергию, нескончаемое ожидание рождает усталость, а смутный страх парализует силы. Оба первых врага атакуют эмигранта в лоб, и ему приходится либо обороняться от них, либо погибнуть, время же атакует и разлагает его» / Ремарк Э.М. Возлюби ближнего своего. М.: Вагриус, 1999. С. 354.

20 Демин А.Н., Попова И.П. Способы адаптации безработных в трудной жизненной ситуации // Социологические исследования, 2000. № 5. С. 40.

21 Муздыбаев K. Переживание бедности как социальной неудачи: атрибуция ответственности, стратегии совладания и индикаторы депривации // Социологический журнал, 2001. № 1.

${ }^{22}$ Бойков В.Э. Россия: десять лет реформирования // Социологические исследования, 2001. № 7. C. 35. 
Таким образом, в плане зависимости/самостоятельности эта группа тяготеет, скорее, к зависимым, поскольку наблюдается неспособность низкоресурсных респондентов своими силами обеспечить себя достаточными средствами к существованию, и то, что никакой поддержки они не получают, способствует углублению их депривации. Однако не подтвердилась гипотеза о том, что самые обездоленные будут иметь и ярко выраженные установки на сочиально-экономическую зависимость на ценностном уровне. Показатели самоэффективности и недостижительских ценностей в этой группе не имеют ярко выраженных отклонений в ту или иную сторону от средних по выборке.

Кластер 2. «Традиционалистьл». Этот кластер образован респондентами, сильно приверженными ценностям утилитаризма и экономического детерминизма, о чем свидетельствует высокое значение фактора «Недостижительские ценности». Структура их установок весьма напоминает усредненный портрет «простого советского человека», нарисованного коллективом авторов под руководством Ю. Левады. По сути, они представляют собой воспроизводящийся тип работников командно-административной экономики, в которой поощрялась, прежде всего, ориентация на стабильное рабочее место путем предоставления широкого спектра льгот и гарантий, не связанных с экономической эффективностью труда.

Действительно, в данном кластере наивысшие оценки значимости таких ценностей, как «Стабильность жизни» (85\% - «очень важно»), «Материальная обеспеченность» $(82 \%)$ и «Личная защищенность» $(72 \%)$. В плане трудовых ценностей у них наибольшая по выборке значимость стабильной оплаты (76\%), стабильной занятости (60\%), атмосферы в коллективе (58\%), режима работы (56\%), условий труда (49\%), близости от дома (47\%), соответствия специальности (46\%), возможности пользоваться льготами (15\%).

Отметим, что в социально-демографическом плане этот кластер ничем не выделяется. Средний возраст и распределение по полу в нем такое же, как в среднем по выборке. Несколько больше, чем в среднем, в нем доля «Работающих бедных». Т.е. подобные установки нельзя объяснить тем, что эти люди принадлежат, допустим, к более старшему поколению или что его составили женщины.

Как видим, в этом кластере, как и в предыдущем, низкое значение фактора «Здоровье», а значит, для этой группы респондентов также характерны состояние повышенной тревожности, зависимости, неуверенности в своих силах, чувство бесполезности, негативные переживания по поводу сложившейся ситуации. Респонденты невысоко оценивают свои профессиональные навыки, отмечают, что не имеют «нужных связей». Это соответствует данным других исследователей, утверждающих, что тяготение к «нормальности», понимаемой как следование традициям, раз и навсегда заведенным нормам, и низкая значимость ценности свободы, независимости, самостоятельности характерны именно для «неадаптированных» групп ${ }^{23}$.

Какие же ресурсы компенсируют низкие показатели здоровья и психологической устойчивости? Анализ показал, что в данной группе это, прежде всего, личное подсобное хозяйство и домашний труд. При том, что представители данной группы отмечают уменьшение своей оплачиваемой занятости, у них вырос объем домашнего труда. То есть эта группа пользуется «подпорками бесплатности» - архаическими стратегиями выживания в условиях отсутствия или нехватки «живых» денег, которые, как известно, сегодня являются весьма распространенными в российском обществе. Известно также, что к стратегии «бегства от рынка» прибегают, прежде всего, низкоресурсные группы, и назвать «конструктивными» эти стратегии весьма сложно, поскольку идет

23 Готлиб А.С. Социально-экономическая адаптация россиян: факторы успешностинеуспешности // Социологические исследования, 2001. № 7. С. 56. 
приспособление не к рыночным преобразованиям, а к кризисным условиям существования ${ }^{24}$.

В этом же ключе отметим выводы, которые эти респонденты сделали из трудной жизненной ситуации. Больше, чем у всех остальных, наблюдаются значения показателей «больше заботиться о своем здоровье» $(73 \%)$, «приспосабливаться к обстоятельствам и людям» (73\%), «экономить, более рационально вести бюджет» $(65 \%)$, «стараться не обращать внимание на трудности» $(64 \%)$, «уделять больше времени и сил своей семье» (44\%). Как видим, претворение в жизнь подобных выводов ни в коей мере не позволит повысить доходы людей, а способно лишь компенсировать недостаточный доход и смягчить психологические последствия бедности.

Таким образом, данный кластер демонстрирует социально-экономическую зависимость на уровне установок - как поиск внешнего источника поддержки, на которого можно переложить ответственность за свое жизнеобеспечение.

Кластер 3. Получатели сочиальной поддержки. Кластер отличается высокими значениями факторов «Социальные ресурсы» и низкими - «Материального положения» и «Здоровья». У них самый высокий показатель получения помощи из разных источников: в среднем каждый респондент в группе получает 5 различных видов помощи. Это, прежде всего, советы, информация, моральная поддержка со стороны родных - 79\%, советы, информация, моральная поддержка со стороны друзей - 79\%, денежная помощь от родных $-62 \%$, вещи/продукты от родных - 61\%. Упоминается также поддержка, которую они получают от государственных органов, общественных организаций.

Обращает на себя внимание, что это «женский» кластер (женщин в нем три четверти). Именно женщины, как известно, более «искусны» в налаживании и поддержании отношений, и в нашем случае именно они оказываются «богатыми» родственниками, друзьями и знакомыми, способными оказать поддержку в трудной жизненной ситуации.

«Социальный» ресурс в данном случае компенсирует недостаточность ресурсов личностных - здоровья, самоэффективности, психологической устойчивости и способности зарабатывать. Их материальное положение - одно из самых плохих (хуже только у кластера 1), для них также характерно снижение уверенности в себе, тревожность. Однако падение их собственных доходов, в отличие от предыдущих кластеров, вызвало значительное увеличение моральной и материальной помощи со стороны их близких. Их поведение в трудной ситуации также направлено на использование своих средовых ресурсов - например, у них преобладает стратегия поиска работы «через родственников и знакомых», чаще остальных они советуются с друзьями и членами семьи, обсуждают с ними свои проблемы и строят планы. Таким образом, являясь «бедными», они не оказались «исключенными», и основой их интеграции является, прежде всего, семья.

Подобные ситуации описаны в зарубежной литературе: в странах, где основой социальной интеграции является семья (таких, как Италия, Испания), потеря работы не ведет к ослаблению семейных связей, и поэтому не происходит «социальной дисквалификации» бедных и безработных. А вот больше всего подвержены риску исключения безработные во Франции, Великобритании, Германии, где семейные и дружеские связи не столь прочны и где безработные лишаются неформальной поддержки со стороны своего

24 См.: Тихонова Н.Е. Шкаратан О.И. Российская социальная политика: выбор без альтернатив? // Социологические исследования, 2001. № 3. С. 28; Ронге Ф. Условия жизни в России // Социологические исследования, 2000. № 3. С. 66-67. 
ближайшего окружения ${ }^{25}$. В данном случае Россия также относится к социумам с большой значимостью персонифицированных отношений, где люди, попавшие в трудную жизненную ситуацию, не только не приобретают стигму «неудачника», но могут рассчитывать на поддержку.

Как и в предыдущем кластере, у этой группы наблюдается значительное увеличение объема домашнего труда. Помимо упомянутой выше стратегии натурализации жизнеобеспечения, можно предположить, что имеет место также необходимость адекватно отвечать на получаемую со стороны родственников поддержку, помогая в хозяйстве, ухаживая за детьми и т.д. Это согласуется с данными зарубежных исследований, поскольку «сеть безопасности» - это еще и «сеть обязательств» ${ }^{26}$.

Таким образом, сочиально-экономическая зависимость представителей данной группь выражена в систематическом получении поддержки извне, делегировании ответственности за свою судьбу ближним - то, что у других авторов получило название «продуктивного иждивенчества» ${ }^{27}$.

Кластер 4. «Пльвущие по течению». Судя по значениям факторов, это кластер, образованный самыми здоровыми (64\% отметили у себя наличие крепкого здоровья) и «психологически устойчивыми» респондентами, но при этом с самыми низкими установками на независимость. Его представители вообще реже других отмечают у себя наличие каких бы то ни было проблем. Собственное самочувствие, отношения в семье, собственное здоровье - по всем пунктам у них показатели обеспокоенности ниже, чем у представителей других кластеров. Четверть их отмечают, что вообще не имеют никаких психологических проблем. Их материальное положение - достаточно хорошее (40\% отметили, что денег им хватает на текущие расходы, что было высшей границей при отборе респондентов для опроса).

Казалось бы, это весьма благополучный, «адаптировавшийся» кластер. Однако их собственная трудовая активность достаточно низка, меньше всех остальных они участвуют во вторичной занятости. И по всем остальным показателям - интенсивности поиска работы, поиску внешней поддержки, работе в домашнем хозяйстве - они значительно менее активны. Меньше других они также рефлектируют свои действия и ситуацию - обдумывают поступки, строят планы, делают выводы. Наименее критично настроены по отношению к себе - не ставят себя в центр своих жизненных планов, но и не занимаются самоедством. В целом можно сказать, что это стратегия «ничегонеделания», отказ воспринимать вынужденный переезд, потерю работы или снижение дохода как «проблему», к решению которой надо прикладывать усилия. В терминологии Фолкмана и Лазаруса ${ }^{28}$ это поведение можно обозначить как стратегию дистанцирования от проблем: они просто не замечают «трудную» ситуацию, она никак не нарушает их эмоциональный

${ }^{25}$ Paugam, S. Poverty and Social Disqualification: a Comparative Analysis of Cumulative Social Disadvantage in Europe. P. 291-292.

${ }^{26}$ Oliker, S.J. The Proximate Context of Workfare and Work: A Framework for Studying Poor Women's Economic Choices, The Sociological Quarterly (Spring 1995). Vol. 36, No. 2. P. 251-264; Edin, K. and L. Lein. Work, Welfare and Single Mothers' Economic Strategies, American Sociological Review (1997). Vol. 62, No. 2. P. 253-254.

27 Демин А.Н., Попова И.П. Способы адаптации безработных в трудной жизненной ситуации. С. 41.

${ }^{28}$ См.: Муздыбаев К. Стратегии совладания с жизненными трудностями. Теоретический анализ // Журнал социологии и социальной антропологии, 1998. Т. 1, № 2. С. 108. 
баланс. Их жизненная позиция весьма близка к свободе-воле ${ }^{29}$, не связанной с ответственностью и активностью, свободе «вольного странника», который, ничем не владея, не боится ничего потерять, и напоминает портреты, например, героев рассказов Дж. Стейнбека:

«Вот вам истинные философы <..> ... они гораздо успешнее, чем другие, выживают на этой земле. В то время, как люди убивают себя, потворствуя своим амбициям и алчности, надрывая нервы, они живут безо всякого напряжения. Все наши так называемые преуспевающие мужчины и женщины - больны, у них расстроены желудки и души. <Они же> здоровы и на удивление чисты. Они делают, что хотят...» ${ }^{30}$.

Итак, данный кластер нельзя отнести ни к «зависимым», ни к «самостоятельным». Не получая поддержки извне и не претендуя на нее, респонденты этого типа не склонны принимать какую бы то ни было ответственность за себя, живя «как придется».

Кластер 5. «Независимые». Этот кластер имеет полюсные значения сразу трех факторов: максимальные - «Материального положения» и «Установок на независимость» и минимальное - «Недостижительских ценностей». Похоже, это единственный кластер, целиком укладывающийся в гипотезу о жесткой взаимосвязи «успешности», «самоэффективности» и независимости как ценности. Рассмотрим его подробнее.

Это по всем показателям наиболее высокоресурсный кластер. Его можно назвать «мужским» (мужчин в нем 68\%, по выборке же их 38\%). В нем самые высокие показатели душевого дохода в семье - 3800 руб. при среднем 1881 руб.; самая высокая имущественная обеспеченность: в среднем имеют более 4 предметов из 12, причем самая высокая обеспеченность наиболее дорогими товарами (каждый третий имеет автомобиль, $28 \%$ - дачу, каждый пятый - персональный компьютер). $63 \%$ оценивают свое материальное положение как «на ежедневные расходы хватает» (напомним, это был возможный максимум по условиям опроса). У них самый высокий уровень образования (53\% имеют высшее). В структуре доходов их домохозяйств самая большая доля зарплаты $(69 \%)$ и самая малая - социальных выплат (пенсий, пособий и стипендий) - 6\%. Их семьи имеют самую маленькую сумму долга.

Их стратегии поведения, вызванные трудной жизненной ситуацией, можно назвать «монетаристскими», поскольку их активность направлена, прежде всего, на увеличение доходов путем оплачиваемой занятости. $74 \%$ имеют приработки, $6 \%$ - собственный бизнес, $44 \%$ отмечают увеличение своей занятости, $47 \%$ - увеличение числа рабочих мест, $32 \%$ - повышение своей квалификации, $40 \%$ - уменьшение свободного времени. Как и у кластера 1, здесь самые низкие показатели получения родственной поддержки, только по иной причине - отсутствия необходимости в этом. При том, что 42\% имеют личное подсобное хозяйство, они никак не выделяются в плане интенсификации работы по дому,

${ }^{29}$ Об оппозиции Свободы-воли и Свободы-независимости см., например: Bellah, R.N. et al. The Good Society. N.Y.: Vintage Books, 1992; Miller W.L., Bellah, R.N. Religion and the Public Good: A Bicentennial Forum. N.Y., 1989; Serover, Ch.M. Time, Freedom and Common Good: An Essay in Public Philosophy. Albany: State University of New York Press, 1989; Хайек Ф.А. Пагубная самонадеянность. Ошибки социализма. М.: Новости, 1992. С. 86-89; Овсянников А.А. Социология катастрофы: какую Россию мы носим в себе? // Мир России, 2000. № 1. С. 77; Лапин Н.И. Социокультурная трансформация России: либерализация versus традиционализация // Журнал социологии и социальной антропологии, 2000. Т. 3. № 3 (11). С. 33; Лапин Н.И. Кризисный социум в контексте социокультурных трансформаций // Мир России, 2000. № 3. С. 32; Вольчик В.В. Либерализм и благосостояние. http://www.libertarium.ru/libertarium/9199.

${ }^{30}$ Стейнбек Дж. Консервный ряд / Стейнбек Дж. Собр. соч. в 6-ти т. Т. 3. С. 572. 
сделав выбор в пользу оплачиваемой занятости. Доля респондента в бюджете своих домохозяйств самая большая - в среднем $62 \%$.

Высокое значение фактора «Материальное положение» показывает, что такая стратегия наиболее эффективна. 33\% даже отмечают рост своих доходов в период «трудной жизненной ситуации». Помимо материальных, такая стратегия приносит и социальнопсихологические вознаграждения: 19\% отмечают увеличение веры в себя, собственные возможности. Высокое значение индекса самоэффективности показывает, что эти люди отличаются интернальным локусом контроля, чувствуют себя способными повлиять на происходящие с ними события и полагаются на собственные способности. Их выводы из трудной жизненной ситуации прямо противоположны кластеру 2: опыт совладания научил их, что надо «пытаться зарабатывать любыми способами» (52\%), «обучаться новым специальностям, приобретать новые профессиональные навыки» (41\%), «открыть собственное дело» (22\%). Их независимость проявляется и в структуре их ценностей, где наиболее высокие по выборке значимости ценностей «уверенности в себе» (74\%), «самостоятельности, независимости» $(65 \%)$, «реализации профессиональных способностей» (45\%), «активной жизни» $(42 \%)$.

Таким образом, респонденты этого кластера характеризуются независимостью как реальной стратегией экономического поведения и независимостью как жизненной позицией. «Независимые» стратегии совладания с трудностями предполагают восприятие трудной жизненной ситуации как «вызова», который, наряду с угрозами, обещзает и потенциальные возможности. Реализаџия «независимой» стратегии связана, прежде всего, с оплачиваемой занятостью.

Итак, анализ стратегий респондентов в плоскости «Самостоятельность - Зависимость» позволил выделить следующие стратегии:

1. Зависимость как неспособность обеспечить себе своими собственными силами минимально приемлемый уровень жизни, которая характерна для наиболее низкоресурсных респондентов.

2. Зависимость как установка, предполагающая ценностное оправдание собственной пассивности, ей соответствуют недостижительские ценности, а в реальном экономическом поведении - компенсация недостаточного заработка натуральным самообеспечением.

3. Зависимость как «иждивенчество» - активное использование внешних источников поддержки, делегирование ответственности за решение своих проблем другим субъектам.

4. «Свобода как воля» - стратегия дистанцирования от проблем и движения по течению.

5. Независимость как стратегия мобилизации индивидуальных ресурсов и совладание с трудной жизненной ситуацией за счет интенсификации оплачиваемой занятости.

К другим выводам, которые позволил сделать анализ материала, относятся следующие.

1. Независимость свойственна, прежде всего, «сильным», высокоресурсным, индивидам, в то время как зависимые низкоресурсные группы обречены в лучшем случае на использование компенсаторных стратегий в виде натурального самообеспечения или привлечения помощи своего ближайшего окружения, либо на углубление депривации в случае отсутствия таких внешних «подпорок».

2. В анализе социологических данных у исследователя существует большой соблазн классифицировать респондентов на группы в зависимости от субъективных факторов (установок, ценностей, суждений). На основе таких 
классификаций нередко делаются далеко идущие выводы о том, что те или иные выделенные группы являются «успешными», «адаптировавшимися», «рыночниками» либо наоборот. Однако, как показывает наш анализ, в реальности классификация гораздо сложнее, она многомерна, и выводы о «стратегиях», например, невозможно делать на основе одних лишь субъективноценностных факторов без выяснения реального экономического поведения и взаимодействия со своим социальным окружением.

3. Первоначальная гипотеза о том, что респонденты с наиболее выраженными установками на независимость будут самыми «успешными», а самые «зависимые» - наиболее обездоленными, оказалась упрощенной. Действительно, «успешная» группа вполне соответствует классическому образу независимого и самостоятельного индивида, чьи вербально выражаемые установки на независимость сопровождаются активными действиями в решении своих проблем. Однако о том, что здесь не существует прямой зависимости, свидетельствуют случаи кластера 2, чьи зависимые установки не сопровождаются резким ухудшением ситуации, и кластера 1 , чье бедственное положение - это, прежде всего, результат отсутствия целого комплекса ресурсов, а ценностный блок, каковым являются зависимые установки, оказывается, скорее, следствием депривации. 


\title{
Дебютные работы
}

$\boldsymbol{V} \boldsymbol{R}$ Мы публикуем фрагмент магистерской диссертации В.В. Алексеева. Работа подготовлена автором в Центре социологического образования Института социологии РАН (2000-2001 гг.) и посвящена исследованию агрессивных практик управления.

\section{АГРЕССИВНЫЙ МЕНЕДЖМЕНТ: ПРАКТИКА УТИЛИТАРНОЙ ЭТИКИ}

\section{Алексеев Всеволод Владимирович}

аспирант Алтайского государственного университета, факультет социологии

Email: ic103wwa@uic.asu.ru

\begin{abstract}
Аннотация
В статье рассматриваются социальные условия, способствующие формированию и проявлению агрессивных управленческих практик в современном российском бизнесе. Анализ основан на исследованиях в сфере малого и среднего предпринимательства, проводившихся отечественными социологами в 1990-е гг., а также на эмпирическом исследовании двух московских фирм весной 2001 г.
\end{abstract}

Современные российские менеджеры испытывают определенные трудности в своей деятельности. С одной стороны, менеджеры - индивидуалисты, оперирующие рациональными принципами полезности, а потому чуждые всякой идеологизированности системы социальных отношений. С другой стороны, многие менеджеры, и особенно менеджеры высшего уровня, ощущают острую потребность в общественном идеале, позволяющем им более предметно понимать основные цели общества. Этот идеал имеет для них практическую ценность, поскольку, опираясь на него, они могут формулировать долговременные ориентиры деятельности предприятий или отраслей экономики.

В обществе существует явно противоречивое отношение к менеджерам (топ-менеджерам), владельцам предприятий и используемым ими практикам руководства. Довольно часто применяются агрессивные управленческие практики, что формирует негативное отношение к руководству со стороны подчиненных. Однако истинные причины и функции подобных практик остаются, как правило, не осознанными ни менеджерами, ни персоналом, ни более широкой общественностью, что приводит к упрощенным трактовкам данного социального феномена.

Агрессивные практики рассматриваются преимущественно как дисфункциональные характеристики управленческой деятельности, связываемые, как правило, с низким уровнем цивилизованности российского общества и бизнеса, некомпетентностью менеджеров, «тяжелым» наследством предыдущего этапа развития страны и т.п. [Сухиненко, Зеленцова 2001]. Однако, на наш взгляд, это отражает лишь одну сторону данного феномена. Нам представляется возможным обосновать и другой аспект проблемы, в соответствии с которым агрессивные управленческие практики являются закономерным, неизбежным, а часто и необходимым атрибутом управленческих отношений в условиях переходного российского общества.

Понятие «агрессивные управленческие практики» имеет следующие значения. Во-первых, агрессивные практики следует понимать как форму властных отношений (т.е. отношений, целью которых является принуждение менеджерами подчиненных к выполнению определенных действий) и как ресурс, к которому менеджеры прибегают в определенных ситуациях, возникающих в процессе управленческой деятельности. Во-вторых, если 
агрессия понимается как намеренное причинение вреда другому человеку, возникает проблема определения того, что считать вредом. По мнению А. Этциони [Этциони 1999], концепция ущерба является довольно сомнительной. Представляется возможным преодолеть эту неопределенность, введя в анализ культурный и, в частности, нормативноценностный аспект вопроса. Это позволяет анализировать те нормативные образцы поведения, которые формулируют для себя и для других сами менеджеры. Иначе говоря, речь идет об управленческих идеологиях. Управленческие идеологии рассматриваются Р. Бендиксом как системы идей, в воспроизводстве которых заинтересованы те, кто использует свой авторитет в экономических целях и ищет объяснение или оправдание своей власти [Романов 2000: 76].

В определении агрессивного менеджмента понятие «намеренное причинение вреда» необходимо рассматривать в трех смыслах. Bo-nервых, это ситуативное нанесение вреда, вызванное каким-то уникальным стечением обстоятельств. Этот аспект агрессивного менеджмента в данной работе не рассматривается. Bo-вторых, нормативно закрепленное причинение вреда. Здесь осуществляется переход от уровня личности к уровню локальной социальной общности. Рассмотрение агрессивного менеджмента под таким углом зрения предполагает введение в фокус анализа неформальных отношений, а точнее, неформальных норм взаимоотношений руководителей и подчиненных.

Существует мнение [Алашеев 1995], что неформальные отношения работают на воспроизводство всей трудовой жизни предприятия; что они, являясь неотъемлемой частью производства, воспроизводят сам процесс изготовления продукции наравне с формальными нормами. Таким образом, если речь идет об агрессивном менеджменте как о совокупности нормативно закрепленных в данной организации управленческих практик (пусть и на уровне неформальных норм взаимоотношений руководства и персонала), то следует говорить о специфической форме организации трудового процесса (о специфической организационной культуре).

$B$-mpeтьих, причинение вреда понимается как одна из практик выживания бизнеса в условиях современного российского общества. Здесь анализ должен быть сосредоточен на социокультурных факторах, детерминирующих возникновение и форму агрессивных управленческих практик. В качестве важного критерия анализа - наряду с экономическим, политическим, идеологическим - выступает господствующий в данном обществе тип этики. В качестве аналитической модели нами выбрана концепция коммунитарного общества А. Этциони.

Рассматривая в качестве объекта данного исследования менеджеров как социальную группу, а в качестве предмета - агрессивные управленческие практики в деятельности данной социальной группы, целью исследования мы избрали определение функций и институционального контекста возникновения агрессивных управленческих практик, используемых руководителями современных частных компаний, как с точки зрения функционирования организации, так и с позиции социокультурных процессов современного российского общества.

Основныли задачами исследования являются следующие:

1) определить роль культуры и этики в формировании и использовании агрессивных управленческих практик;

2) на основе исследований современного отечественного менеджмента сформулировать гипотезы о причинах, функциях и распространенности агрессивных управленческих практик;

3) на базе эмпирического исследования построить объяснительную модель присутствия агрессивного менеджмента в социальном пространстве современного российского общества. 
В процессе анализа было выделено несколько факторов, послуживших основой для формирования теоретических гипотез исследования. Эти факторы и соответствующие гипотезы описываются ниже.

А. Агрессивность внешней среды является одним из наиболее существенных факторов агрессивного менеджмента.

1. Российский менеджмент действует в условиях жесткой агрессивной среды, что требует адекватных реакций с его стороны.

2. Агрессивные методы, в том числе методы взаимодействия с партнерами по бизнесу, являются необходимым условием ведения бизнеса и, в целом, выживания организации в современной России. В этом смысле агрессивные практики являются ресурсом формирования новых хозяйственных субъектов.

3. Модель агрессивного взаимодействия с организационным окружением переносится менеджерами и на внутриорганизационные взаимодействия.

Б. Степень жесткости вертикальной иерархии напрямую связана с вероятностью проявления агрессии в управленческих отношениях.

1. Патернализм и авторитаризм, унаследованные от советской системы хозяйствования, оказывают значительное влияние на формирование управленческих идеологий руководителей современных частных предприятий.

2. В условиях экономической и правовой неопределенности наиболее эффективным является принцип концентрации власти. В этом смысл, агрессивные управленческие практики становятся ресурсом современного менеджмента.

Рассмотрим выделенные факторы более подробно.

\section{Агрессивность внешней среды - фактор агрессивного менеджмента}

Сегодня все исследователи разделяют мнение о том, что в современной России бизнес действует в условиях жесткой и даже агрессивной среды. Эта среда характеризуется следующими явлениями.

1. Государственный (налоговый) рэкет, выражающийся в завышенных фискальных ставках (превращающих любой немонопольный бизнес в нерентабельный) и заставляющий предпринимателей уходить в «тень».

2. Чиновничий рэкет - коррупция. Ответ - опять-таки «уход в тень»: не засвечиваться, не вести никакой открытой деятельности, лучше одну за другой открывать и закрывать фирмы. Честному предпринимателю в таких условиях работать практически невозможно, зато принимающим подобные правила игры - очень даже неплохо. Последние готовы платить штрафы и давать взятки за свой полулегальный и нелегальный бизнес. Такое положение вещей сознательно поддерживается госчиновниками, обладающими «разрешительными полномочиями» [Бабаева 1997: 100]. (В социалистической системе хозяйствования действовал разрешительный, а не регистрационный принцип, который отразился в организации бизнес-деятельности (на всех ее этапах), плавно перекочевав из планово-государственной советской в так называемую рыночную российскую экономику.) В таких обстоятельствах бизнесменов пугает не только сбор налогов как таковой, но и то, что в любой момент можно доказать преступный характер их деятельности. Фактически отношения между предпринимателями и чиновниками в современной российской экономике носят характер неформальной взаимозависимости. Этот тип отношений описали исследователи, изучавшие крупные российские промышленные предприятия в 19921995 гг. Как отметил Леонид Сартания (генеральный директор ООО «Сапфир и К $\left.{ }^{0} »\right)$ в 
беседе с корреспондентом журнала «Я \& Бизнес», «нашему бизнесмену важнее всего научиться общению с госчиновниками. Закон часто допускает двойное толкование, в результате чего возникает конфликт» [Романюк: 62].

\section{3. Рэкет организованной преступности.}

4. Кроме указанных выше факторов, несомненно, стоит говорить и об экономической конкуренции. Однако сама по себе конкуренция относится к естественным факторам, стимулирующим развитие бизнеса, и присутствует всегда и везде, где существуют рыночные отношения. Агрессивным фактором среды она становится, лишившись цивилизованных механизмов регуляции и приобретя нерыночный характер. Нечестность деловых партнеров, «кидающих» и «подставляющих» друг друга, использование противозаконных методов разрешения конфликтов и пр. - все это факторы, переводящие конкуренцию из разряда рыночной в нерыночную.

Модель общения с агрессивной средой вольно или невольно переносится предпринимателем-менеджером на внутриорганизационный уровень. Вероятно, именно совмещение роли собственника и директора предприятия накладывает отпечаток на стиль руководства, делая его более жестким.

Проблема риска - одна из наиболее существенных при изучении российского предпринимательства. «России переход к “мягкому” менеджменту пока не грозит, считает Игорь Бунин, ведущий российский эксперт по проблемам развития предпринимательства. - Успеха в деле добиваются люди с сильным или даже агрессивным началом» [Бунин 1994: 256]. И хотя эта оценка была сделана семь лет назад, она в значительной степени остается актуальной и сегодня. Ряд исследований российского предпринимательства, проведенных под руководством В.В. Радаева, А.Е. Чириковой, Е.С. Гвоздевой, Л.В. Бабаевой и других ученых, подтверждают справедливость этого тезиса. Так, например, опрос региональных предпринимательниц, проведенный под руководством А.Е. Чириковой, показал увеличение числа предпринимательниц, убежденных в том, что только стратегии риска способны помочь выжить бизнесу в современных условиях. Причинами этого являются, с одной стороны, рост конкуренции, а с другой - особенности деятельности региональных предпринимателей, вынужденных выживать в более агрессивных условиях [Чирикова 1998].

Без сомнения, агрессивность среды, в которой действуют бизнесмены, накладывает отпечаток и на характер их отношений с персоналом, на построение внутрифирменной политики. Однако существуют и другие факторы, определяющие специфику менеджмента. Одним из таких факторов являются управленческие традиции, сформировавшиеся в нашей стране в предыдущие десятилетия.

\section{Социокультурные факторы агрессивного менеджмента (патернализм)}

Несмотря на то, что отечественные предприниматели декларативно ориентированы на западный стиль деловых отношений, в реальном поведении они часто демонстрируют патриархальные традиции. Это проявляется, прежде всего, в стиле работы с персоналом. Лучше взять на работу «своего» или рекомендованного «своим», чем приглашать специалиста по конкурсу. Подобная установка пустила крепкие корни. Неопределенность правовой ситуации, в которой приходится действовать негосударственным коммерческим предприятиям, требует безусловной надежности и доверительности в отношениях между сотрудниками. «Свой», пусть даже менее подготовленный, - это все-таки член «клана». «Чужой» - только партнер, с которым нужно устанавливать отношения на жесткой, но четкой договорной основе. Вскоре начинают сказываться дефекты ориентации на «свойство». Нанимателя и нанимаемого (т.е. «своего») связывают определенные ожидания и иллюзии, которые могут подвести обоих. «Свои» часто не оговаривают в 
деталях условия сотрудничества. Тот, кто берет на работу, ждет личной преданности и лояльности по отношению к фирме, а тот, кого берут, нередко считает, что ему будут предоставлены особые привилегии, а ошибки будут прощаться [Перепелкин 1995: 37].

Хотя тенденция набора сотрудников «по знакомству» продолжает действовать и сейчас, набирает силу альтернативная тенденция приема персонала (как рядового, так и руководящего) по конкурсу на основе обезличенной оценки профессиональной квалификации [Бабаева, Лапина 1997: 55].

Набор персонала по знакомству - это лишь одна из черт патриархальных традиций, действующих в современном российском бизнесе. Патернализм как социальный феномен гораздо более многогранен и характеризуется в литературе следующим образом. Ему свойственна четко выраженная иерархичность отношений. Права «хозяина», который обычно принимает единоличные решения, неоспоримы. От подчиненных ожидается лояльность по отношению к начальнику. Вдаваться в смысл тех или иных решений им не обязательно. «Хозяин» бдительно контролирует действия своих подчиненных, но при необходимости берет на себя часть возложенных на них функций. Организация труда носит достаточно гибкий характер, исполнители могут периодически замещать друг друга в напряженных ситуациях. Ответственность за провалы - общая, коллективная. «Хозяин» поддерживает единство организации, но не путем формальной регламентации, а через утверждение своего личного влияния. Несмотря на строгую иерархию, взаимоотношениям придается личностный характер, выходящий за сугубо служебные рамки. Внерабочие проблемы подчиненных также становятся предметом непосредственной заботы и опеки со стороны руководителя [Радаев 1994: 149]. Однако патернализм предполагает не только опеку, но и принуждение. Границы допустимого принуждения вариативны и зависят от разных причин [Романова 2000: 26]. Таким образом, можно заключить, что ключевым моментом в патерналистских отношениях является зависимость работника от руководителя. Эта зависимость является желанной для работника-«патерналиста», поскольку, делегируя руководству ответственность за определение и реализацию своей жизненной стратегии, он таким образом освобождает себя от ответственности принимать самостоятельные решения в проблемных ситуациях [Темницкий 2000: 56-57].

Распространенность в нашей стране подобной формы трудовых отношений подтверждается рядом исследований, проведенных как на крупных промышленных предприятиях, так и в малых и средних частных фирмах. Вот что пишет по этому поводу один из участников проекта «Крупные промышленные предприятия: перестройка управления и трудовых отношений» П.В. Романов: «Наверное, невозможно понять суть происходящих сегодня на предприятиях России социально-экономических изменений без понимания их механизма, сложившегося в результате всей семидесятилетней истории советского общества. Система управления, распределения и информационного обмена продолжает воспроизводиться в новых условиях и является тем контекстом, на который накладываются нынешние инновации. На наш взгляд, понятие патернализма наиболее точно и полно характеризует многие стороны жизни российских предприятий: поведенческую стратегию руководства, взаимоотношения в трудовых коллективах, взаимодействие уровней производства и стереотипные ожидания рабочих» [Романов 2000: 13]. Однако, по мнению А.Л. Темницкого, между прошлым «советским» и нынешним «постсоветстким» патернализмом имеется существенное различие. При «советском» патернализме акцент делается на «самовоспроизведении» отношений лояльной зависимости. При «постсоветском» эти отношения следует заслужить [Темницкий 2000: 64].

Можно было бы возразить, что крупные промышленные предприятия - это совершенно иной тип организаций, нежели малый и средний бизнес: они гораздо более инертны, и именно поэтому в них еще проявляются патерналистские отношения, унаследованные от прежнего общества. Однако исследования в сфере среднего и малого бизнеса опровергают 
подобного рода аргументы. Конечно, в малом бизнесе патернализм не так масштабен, как в промышленности, хотя бы потому, что здесь он не оказывает значительного влияния на внерабочую жизнь своих сотрудников в силу отсутствия так называемого соцкультбыта. Тем не менее, основные черты патерналистских управленческих стратегий успешно адаптируются современным бизнесом. Так, результаты исследования женщинруководителей малых и средних фирм Москвы показали, что руководители предпочитают использовать принцип концентрации власти, четкую иерархию отношений. Наблюдается тенденция отказа от статусного лидерства в пользу харизматического [Чирикова, Кричевская 2000]. Такие тенденции современных руководителей определяются не только факторами агрессивной внешней среды, но и определенными ориентациями их подчиненных.

Исследования, проведенные на частном швейном предприятии Москвы в 1990-е гг. [Темницкий 2000], также зафиксировали, что ориентация на партнерские отношения с руководством не особенно выражена в рабочей среде. Во взаимоотношениях патерналистских и партнерских ориентаций патернализм не только остается ведущим принципом, но и является притягательным для большинства работников частного предприятия. Была выявлена ориентация рабочих на неоспариваемое выполнение любых заданий руководителя, на дружеские и доверительные отношения с руководством и отсутствие ориентации на обладание полной информацией о делах предприятия.

Патерналистские ориентации рабочих обладают на сегодня более сильным, по сравнению с партнерскими, потенциалом конструктивности их использования. Рабочие«патерналисты» демонстрируют более высокий уровень ответственности за работу всего предприятия и за использование рабочего времени.

Эти выводы авторы исследования объясняют тем, что партнерство, предполагающее равноправное взаимовыгодное сотрудничество, является более трудным путем, требующим значительных интеллектуальных и волевых усилий при построении стратегии отношений руководства - подчинения. Однако на сегодня рабочий-«партнер», который должен обладать качествами «сильного» работника (высокий уровень профессиональной компетентности, дисциплинированности и т.д.) и не иметь неудовлетворенных бытовых потребностей, является малораспространенным типом [Темницкий 2000: 64-65].

\section{Нормативность и необходимость агрессивных практик в управленческой деятельности в современном отечественном бизнесе}

Расширение в России сферы негосударственной экономики приводит к утверждению частной собственности на хозяйственные ресурсы в качестве нового источника власти. Принято полагать, что здесь формируется особая среда трудовых отношений, отличающаяся большей жесткостью, деловой хваткой и ориентацией на эффективность [Радаев 1994: 149]. В условиях нестабильной экономической ситуации большинство руководителей (как мужчин, так и женщин) предпочитают использовать принцип концентрации власти внутри фирмы, хотя технология, строящаяся на таком принципе, полезна и при построении деловых отношений с партнерами. Влияние отдельных сотрудников должно определяться близостью к руководителю и тем потенциалом влияния, который руководитель делегирует своим партнерам. Четкая иерархия отношений в таком взаимодействии позволяет снизить потенциал возможных конфликтов, усилить контроль над ситуацией, ускорить принятие решений в стремительно изменяющихся условиях.

Исследование, выполненное в 1995-1997 гг. А.А. Возьмителем, Л.Е. Душацким, Е.Я. Таршисом, показало, что российские предприниматели, как правило, формулируют для себя и окружающих просоциальные системы ценностей и мотивов своей 
деятельности, однако на практике они зачастую вынуждены действовать совсем по иным законам. Возможно, специфика российского бизнеса состоит в том, что благие намерения бизнесменов реализуются антисоциальными способами. Исследование выявило тенденцию роста успешности бизнеса по мере снижения степени его цивилизованности. Иными словами, цивилизованный бизнес в нецивилизованной стране экономически малоэффективен и потому не получает должного развития. По мнению авторов, нельзя рассчитывать, что доминирующий в России тип предпринимателя в скором времени изменится [Душацкий 1999: 94].

При явной неопределенности моральных установок ${ }^{1}$ большинства участвующих в малом бизнесе субъектов (которые вынуждены были расстаться со вчерашними нормами и принципами, но еще не выработали новых моральных ценностей) побеждает диктат сильного, а точнее - того, кому эту болезненную психологическую ломку вообще не нужно переживать. На практике это выражается в том, что наиболее «сильным» в данной среде является тип, изначально отвергавший ценности прежде существовавшей социальной системы и потому не обремененный психологическим наследием [Бабаева, Лапина 1997: 176].

Подобное положение является проявлением естественного хода вещей - как бы «природного» развития. Пока процесс формирования предпринимательского класса (точнее, достаточно четко очерченных социально-экономических групп внутри него) не закончился, пока естественным образом не сформировалась элита этого класса (способная утвердить и закрепить некие присущие ему ценности, одновременно не противоречащие общечеловеческим, и распространить их на все общество), в среде малого бизнеса будет преобладать психологический тип с авантюристическими наклонностями [Бабаева, Лапина 1997: 173].

Высококвалифицированные менеджеры, получившие качественное образование западного образца, оказываются в сегодняшней ситуации ненужными, так как сложившаяся «система» отторгает их [Сухиненко, Зеленцова 2001: 27].

Люди, прошедшие обучение менеджменту на основе западных принципов и образцов управления, часто оказываются неадаптированными к российской социальноэкономической действительности. Они знают, как делать «правильный» бизнес, но в реальности попадают в ситуацию, когда от управленца требуются совсем другие качества и умения - используя различные средства, в том числе внеэкономические, заставить поставщика ждать деньги, а потребителя - платить. Как отметила Наталья Алещенко (директор фонда «Женская инициатива») в беседе с кореспонденткой журнала «Я \& Бизнес»: «...нашему предпринимателю, прежде всего, необходимо учиться цивилизованному бизнесу. Решая вопрос о том, чему учить предпринимателя, надо иметь в виду, что он должен оставаться культурным и образованным, действуя в достаточно агрессивной среде» [Романюк 2001: 62-63].

Современный этап развития экономических отношений в России характеризуется высоким уровнем неопределенности, рисков и угроз. Субъекты экономических отношений, действующие в таких условиях, вынуждены выстраивать модели взаимодействия, дающие возможность каким-то образом стабилизировать ситуацию, взять ее под контроль. Сложные модели взаимодействия экономических субъектов, предполагающие использование хорошо разработанных процедур привлечения третьих лиц, участия государства, практикуемые в экономически развитых демократических

\footnotetext{
${ }^{1}$ На наш взгляд, скорее следует говорить о двойных моральных стандартах: «личных» и «профессиональных». В первом случае речь идет о менеджере как о человеке и о том, чего он хочет, а во втором - о том, что он действительно вынужден делать. Две эти этики могут конкурировать или конфликтовать между собой.
} 
странах, зачастую оказываются неэффективными в условиях кризисного состояния нашей страны. В результате широкое распространение в менеджменте получили более простые и радикальные управленческие практики, среди которых особое место занимают агрессивные средства и способы построения отношений как с деловыми партнерами, так и с персоналом собственных организаций. Исследованию внутрифирменных отношений персонала и руководства и посвящена эмпирическая часть данной работы.

Ориентация исследования на изучение управленческих идеологий, формулируемых самими руководителями, стремление подтолкнуть их к рефлексии относительно управленческих практик вообще и собственных практик в частности дает основание избрать качественную методологию как наиболее адекватную целям данной работы.

\section{Методика исследования}

В данном исследовании использовалось глубинное направленное интервью. Для его проведения был создан путеводитель из 19 базовых вопросов. Вопросы путеводителя являлись лишь опорой и в процессе реального интервью могли видоизменяться.

Структура путеводителя имеет три смысловые части. Первая касается структуры и сферы деятельности организации, в которой проводится исследование; принципов, лежащих в основе внутриорганизационных отношений. Она направлена на изучение того, какова, в общих чертах, организационная культура данной фирмы. Вторая часть затрагивает тему представлений респондента о функциях менеджера, о том, что, по его мнению, делает руководителя «настоящим» руководителем. Третья часть фокусируется непосредственно на теме агрессивного менеджмента. Причем она строится таким образом, что в процессе интервью респонденты выступают скорее как эксперты, размышляющие о том, что такое агрессивный менеджмент, нежели как субъекты, использующие агрессивные управленческие практики в своей деятельности. Такой характер построения вопросов обусловлен двумя особенностями. Во-первых, задачей выявить представления и стереотипы руководителей относительно того, что такое агрессия в управленческих отношениях. Это понятие является ключевым, так как четко ориентирует респондента на анализ совершенно определенного аспекта управленческой деятельности. Во-вторых, в силу табуированности данной темы задавать прямой вопрос: «Проявляете ли Вы агрессию в управлении персоналом и в каких формах Вы это делаете?» - совершенно невозможно, так как на него будет получен отрицательный ответ. Однако когда задается вопрос о знаниях, представлениях респондента, а не о его реальном поведении в конкретных ситуациях, проблема неответа или отрицательного ответа снимается. Кроме того, предполагается, что при определении и объяснении данного понятия респондент вольно или невольно будет опираться на свой опыт, что даст возможность в определенных пределах судить о реальных агрессивных практиках, используемых им в своей управленческой деятельности.

Исследование основано на целеориентированной выборке критических случаев. В качестве таких случаев выступали две организации с разным типом организационной культуры и видами деятельности. Это позволило сравнить полученные результаты и проследить, существует ли принципиальная разница в использовании агрессивных управленческих практик, их значении и обосновании руководителями.

В выборку вошли две частные московские фирмы, относящиеся к разряду малых: Частное охранное предприятие и Агентство, занимающееся управленческим консультированием. В описании и интерпретации результатов каждая фирма анализировалась как отдельный кейс, что позволило создать два образа управленческой и организационной культуры и затем сформулировать общие выводы, касающиеся агрессивного менеджмента. 


\section{Кейс №1. Культура дисциплины (Частное охранное предприятие) Организационная культура, структура и тип власти}

Частное охранное предприятие (ЧОП) было организовано в 1997 г. и насчитывает 50 работников. Руководящий состав включает генерального директора, заместителя и главного бухгалтера. Бухгалтер (жена генерального директора) также участвует в приеме кадров. Все трое являются соучредителями предприятия.

Это мужской коллектив, состоящий из бывших военнослужащих, как правило, офицеров, что создает определенную организационную культуру, которую условно можно назвать культурой «дисциплины». Причем эта культура формируется не столько в самой организации, сколько переносится из уже существующего социального института (армия), где подчинение старшему по званию является не только нормой, но и обязанностью.

«Раньше я принимал на работу бывших милиционеров, а теперь предпочитаю работать с военными, как правило, офицерами запаса, так как они знают, что такое дисциплина. Частный охранник должен быть строгим, тактичным и коммуникативным. Он должен нравиться заказчику, иначе при малейшем замечании будет уволен».

Речь идет о специфической организационной культуре, которая определяется двумя важнейшими факторами: полом сотрудников и военным типом организации. Можно предположить, что в данной культуре крик руководителя или даже оскорбление подчиненного допустимы, если они «за дело». Кроме того, это может свидетельствовать просто о специфическом дискурсе данной культуры, хотя заместитель директора и декларирует принцип корректного поведения:

«Руководитель, по нашим понятиям, как у нас в фирме принято, должен быть всегда вежливым и корректным, потому что, когда руководитель сорвался, нахамил..., руководитель всегда должен быть корректен и вежлив к клиентам, ко всем. К подчиненным у нас такой принцип работы, не надо никогда ни кричать, ни топать ногами. Ну, бывают разные моменты с людьми, когда при увольнении или еще что. Надо корректно объяснить ребятам, почему и за что. Никогда не надо повышать голос, кричать, толку от этого не будет» [интервью 2].

Однако подобная практика демонстрирует неформальные отношения и связана скорее с личностью человека, по отношению к которому она применяется, чем с его профессиональными качествами. Иначе говоря, руководитель «переходит на личности».

«При общении с сотрудниками иногда приходится повышать голос, так как военные, привыкшие к приказным отношениям, часто лучше понимают такое обращение, чем вежливую просьбу выполнить мое распоряжение. Это специфика мужского коллектива. Например, не вышел у меня человек на объект, я звоню своему заместителю и говорю, что надо подменить, а он "закрутился" и забыл. Я приезжаю в офис и говорю ему: "Тьь дурак, что ли?!"».

На вопрос о том, как, по его мнению, в таких случаях чувствует себя его заместитель, респондент ответил: «Ну, он краснеет, чувствует, что виноват, испытывает угрызения совести».

Создание чувства вины у подчиненного, возможно, является важной управленческой практикой: за неудачи, ошибки подчиненного в выполнении им своих обязанностей наказанию подвергается он как личность, а не как профессионал. В этом случае личность человека связывается с профессиональными функциями, которые он выполняет. Вероятно, это позволяет сделать отношение работника к его профессиональным функциям более внимательным, они становятся значимыми лично для него. Это мобилизует 
работника, заставляет более ответственно относиться к делу ${ }^{2}$. Кроме того, человеком, у которого создается чувство вины, легче руководить. Пожалуй, это довольно удачная, хотя и очень агрессивная практика. Хорошо известно, что ценности, стереотипы, нормы, лежащие в основе как индивидуальной, так и социальной культуры, довольно медленно поддаются трансформации. В таком случае, где же предпринимателю взять необходимых для рыночной экономики работников? Даже если работник - отличный профессионал, его личностные качества могут препятствовать успешной работе в условиях рыночных отношений. Это особенно важно, когда речь идет о руководящих работниках.

«Самое сложное - найти хоромего заместителя. Он должен быть инициативным, должен не бояться ответственности».

В этом смысле агрессивные практики, в том числе создание чувства вины, могут носить воспитательный, социализирующий характер, а руководитель - играть роль воспитателя. Таким образом, эта исключительно психологическая, межличностная практика приобретает социологическое значение - формирование у работника нового отношения к делу. Ее использование руководителями может быть исключительно инструментальным. Менеджеры прекрасно осознают воздействие такой практики на подчиненных и прибегают к ней в случае необходимости. Подчиненный сразу начинает ощущать личную ответственность за выполняемое им дело.

Значимость для бизнеса такого качества, как способность брать на себя ответственность за выполняемое дело, наглядно демонстрирует следующий фрагмент интервью.

«Я создал охранное агентство только тогда, когда понял, что знаю достаточно и готов к ответственности. Вообще я люблю начинать с нуля. Уиел из МУРа в никуда, просто написал заявление и ушел. Теперь я знаю, что, даже если все мои подчиненнье уйдут от меня, то я создам новое агентство, это меня не пугает, так как я перестал бояться ответственности. Моя фирма - это я. Проколь фирмы - это мои проколь»».

Этот фрагмент свидетельствует еще об одном факте: данный руководитель воспринимает себя как сильного независимого человека, хозяина своей судьбы и своего дела, которого не страшат неопределенность и трудности. Желание начинать с нуля - одна из важных характеристик успешных бизнесменов, о чем свидетельствуют исследования предпринимательства, проведенные в последние годы [Бунин 1994, Бабаева 1997, Чирикова 2000]. Кроме того, он позиционирует себя как справедливого руководителя, который заботится о своих людях.

«Своим подчиненным я плачу чуть больше, чем в других ЧОПах. Кроме того, два раза в год выплачиваю премии, на праздники поздравляю семьи охранников. Забота о людях это скорее мораль. Я сам долго работал в милиции и знаю, что такое формальное отношение. Когда тебя награждают грамотами, званиями, значками, но делается это чисто формально, ты на самом деле никого не интересуешь. Другое дело, когда я своему работнику на праздник дарю открытку, а в ней - “соточка”, человеку приятно. Людям нравится работать в моем коллективе. Даже те, кто получают высшее образование, остаются у меня. Есть те, кто подолгу ждет места в моей фирме, чтобы устроиться сюда».

Власть внутри фирмы сконцентрирована в руках директора, а заместитель (одновременно являющийся и соучредителем), хотя и не удовлетворяет его как руководитель (неинициативен), продолжает занимать свою должность просто потому, что они вместе

2 Вероятно, это может быть одним из факторов, объясняющих повышенную ответственность работников-«патерналистов» в отношении не только своих профессиональных функций, но и предприятия в целом. 
начинали дело ${ }^{3}$. Подобная «жалость» к своему профессионально несостоятельному помощнику, забота о сотрудниках, жесткая иерархия власти - все это может говорить о наличии патерналистских ориентаций руководителя данной организации, и - судя по тому, что людям нравится работать в его фирме, - об аналогичных ориентациях подчиненных. Кроме того, подчеркивается роль материального вознаграждения (высокая зарплата, премии) в кадровой политике и высказывается пренебрежение к различного рода символическим наградам (значкам, грамотам, званиям и т.п.), что свидетельствует о доминировании в данной организации утилитарного типа власти. Однако дисциплинарный характер данной культуры, развитые неформальные отношения и патерналистские тенденции делают достаточно значимой нормативную сторону жизни организации и, следовательно, использование руководством нормативной власти.

"Я не “покупаю” людей. Даже когда кто-то из моих людей хочет уйти в другое место, например, ему там больше обещают, я предлагаю ему поработать там какое-то время, не увольняясь отсюда. Если ему там не понравится, то он вернется. Однако если человек увольняется из моего агентства, то назад я его уже не принимаю. Это мое жесткое условие».

«К охранникам у нас два принщииа: предупреждать, если по какой-то причине опаздываешь или не выходишь на работу, и чтобы охранник приходил на работу трезвым и был на работе трезвым. Предупреждаешь ребят: "Позвони, скажи, что заболел, лучше отсидись дома". Кто-то понимает, а кто не понимает, с теми мы расстаемся. А так говорится потому, что народ у нас все-таки пьющий».

\section{Агрессия как несправедливость: интерпретации понятия «агрессивный менеджмент»}

Первой реакцией генерального директора на вопрос о том, что значит руководить агрессивно, было:

«Слово “агрессивное” мне не нравится, оно имеет негативный смысл. Я бы сказал «наступательное руководство».

Собственно говоря, нами и предполагалось, что данное понятие вызовет подобную реакцию. В обыденном сознании за понятием «агрессия» устойчиво закрепился негативный смысл. С другой стороны, интересно то, что респондент сразу уточнил, что лучше использовать понятие «наступательное руководство». Это может свидетельствовать о том, что так или иначе данный руководитель сталкивался с необходимостью осмысления агрессивных практик в своей деятельности. В результате он сразу определяет альтернативу агрессивному поведению.

«Мне часто приходится принимать решения в быстро изменяющихся ситуациях, поэтому нужно действовать оперативно. Советоваться, просить нет времени, так как у меня нет права на ошибку, я как сапер. Я должен четко формулировать задачи подчиненным и требовать их неукоснительного исполнения. Например, если кто-то не вымел на работу, то я звоню тому, у кого выходной и говорю: “Ты должен быть через

3 «Терпимость» по отношению к своему неинициативному заместителю может быть объяснена и иначе. Хорошо известен принцип дополнительности при формировании управленческой команды. В соответствии с этим принципом руководитель подбирает помощников «под себя», т.е. так, чтобы они компенсировали его слабые стороны. В этом случае «мягкий», неинициативный, но исполнительный заместитель уравновешивает ярко выраженную напористость, активность и предприимчивость своего начальника. 
два часа там-то и там-то”. Меня не интересует, что у него дома, какие у него планы, в этот момент я должен заботиться об организации, а не о данном человеке. Конечно, за сверхурочную работу я повышаю ставку. Наступательность - это мгновенное принятие правильного решения».

Здесь респондент формулирует принципы руководства, которые, по результатам многих исследований [Бабаева 1997, Чирикова 1997, 2000, Сухиненко и Зеленцова 2001, Темницкий 2000 и др.], являются довольно распространенными в современном отечественном бизнесе: концентрация власти в руках топ-менеджера, приоритет задачи над отношениями и т.п. Использование данных принципов обосновывается предпринимателями тем, что они являются наиболее адекватными в существующей экономической ситуации. Это подтверждает гипотезу о том, что модель взаимодействия с агрессивной средой переносится в организационную среду. Неопределенность постоянно изменяющегося организационного окружения, риски, с которыми сталкивается руководитель («у меня нет права на ошибку, я как сапер»), делает самого руководителя агрессивным фактором для подчиненных. Например, если того требует ситуация, он в любой момент может приказать человеку выйти на работу, даже если у того выходной: «Меня не интересует, что у него дома, какие у него планы, в этот момент я должен заботиться об организации, а не о данном человеке». Несмотря на то, что он выплачивает сверхурочные подчиненному, а также пытается объяснить ему свое решение, факт остается фактом - у подчиненного нет выбора, он не может отказаться без негативных для себя последствий. Здесь действует такой же приказной порядок, что и в армии. Только, в отличие от армии, за выполнение приказа следует реальное вознаграждение, а не только благодарность.

Заместитель генерального директора, напротив, затруднился дать определение агрессивного управления:

«Вопрос очень высоких материй, может быть. Я не знаю, я не могу понять не то что самого вопроса, а того, что такое агрессивное управление. Сейчас модно говорить «агрессивный стиль руководства» и все прочее».

Вероятно, это связано с тем, что заместитель рассматривал данное понятие в более широком межличностном контексте отношений в организации, в то время как директор формулировал его с точки зрения принятия организационных решений.

Оба руководителя данной организации отмечают, что агрессия всегда связана с нарушением определенных ценностно-нормативных условий, как с точки зрения общечеловеческих ценностей, так и с точки зрения профессиональной этики.

«Агрессивность - это неуважение к мнению подчиненного, чрезмерно приказной тон, когда приказы не объясняются. Такой руководитель любую девчушку, которая находится в его подчинении, может послать на хрен. Агрессия - это неуважение чужого “я". Учеловека есть свой мир, куда ты вторгаешься и навязываешь свое мнение. Агрессивность - это чванство, самодурство».

«...Если говорить об агрессивном стиле руководства, то это когда, если грубо сказать, человек идет "по трупам" к повышению, через “бурелом” поперся. Такие люди агрессивные. Для меня, если человек нагльии, ... он идет “по трупам”, несмотря ни на ранги, ни на что. ... Агрессивный стиль руководства - это руководство наглое, обижающее других людей».

В этом смысле явно выраженные проявления агрессии (физическое насилие, крик, оскорбления) не являются обязательным условием отнесения управленческих практик к агрессивным. Основной параметр - это нарушение критериев справедливости (как она понимается в данном сообществе или в общечеловеческом смысле) в отношениях с 
подчиненными. Поэтому сюда же, по словам заместителя, можно отнести различного рода проявления «хамства». Под хамством понимается следующее.

«Вот когда я работал в другой охранной фирме, у нас был “хороший” генеральный директор, который всегда ульбался и говорил, мол, знаете, ребята денег на зарплату нет. Агрессивный, в моем понимании, - это вот “ты такой, сякой”, там все прочее. Это такое подспудное определение. А здесь человек мелко, потихоньку. Как я рассказывал, он ульбается, не выплатил нам денег... Вот так человека мурыжат, мурыжат. Если ты обещуал человеку, сделай. Если сразу знаешь, что не можешь, то не обещай человеку никогда. Если ты пришел устраиваться на работу, у тебя есть определенные обязанности, а тебя потом начинают нагружать дополнительными за ту же самую зарплату, то это уже не совместимо с тем, что есть».

Речь здесь идет о том, что оба руководителя формулируют определенные этические нормы, причем осуществляется попытка вписать этику профессиональных отношений в общечеловеческую этику. На практике же следование этим принципам им не всегда удается. Так, по словам заместителя, генеральный может иногда и «с плеча рубануть»:

«...Он сначала решает, и только потом мы начинаем разговаривать и можем придти к другим мнениям. Он, конечно, прислушивается к нам, но может и жесткое решение принять. Оно и правильно».

Несмотря на то, что заместитель считает такую практику руководителя правильной, на вопрос о том, что чувствуют окружающие, когда генеральный ведет себя подобным образом, он ответил:

«Какое-то чувство неудовлетворения есть. Надо сначала переговорить, а уж потом это самое...».

Согласно данному заместителем определению агрессивного руководства, подобную практику следует отнести к агрессивному поведению - ведь она вызывает неудовлетворение, обижает. Однако он объясняет, почему такое поведение руководителя правильно:

«Наша милицейская система какая была, такая и осталась. Есть руководитель, который это самое, он и не должен быть мягким, он жестким должен быть, требовательным, это накладывает его специфика работыл».

Иначе говоря, причинение вреда здесь легитимировано определенной корпоративной культурой, в которой создается образ жесткого, требовательного начальника. С точки зрения данного респондента, жесткость не является агрессивностью, хотя, по сути, имеет те же самые последствия для подчиненного. В результате, по определению А. Этциони, в данной фирме имеет место организационное согласие.

Гуманистическая направленность директора отступает перед требованиями внешней среды и необходимостью сохранения организации. Однако он не считает свою управленческую стратегию агрессивной, определяя ее как наступательный стиль (или, в крайнем случае, как напористый), который хотя и может быть жестким, основанным на единоличном принятии решения, характеризуется «прозрачностью» (понятностью подчиненным). В этом, по мнению генерального, принципиальная разница между агрессивностью и наступательностью.

«Агрессивность может причинять моральное неудовольствие, а наступательность нет. Но даже если мое решение вызывает у человека неудовольствие, то я должен объяснить ему причину этого решения и компенсировать его неудовольствие. Например, если парень хотел пойти со своей девушкой в кино, а я заставляю его выйти на подмену, то я должен объяснить ему, что на заработанные за сверхурочную работу деньги, он сможет сводить свою девушку не только в кино, но и в ресторан». 
Обоснование решения может следовать как до, так и после того, как оно сформулировано для подчиненного. В последнем случае обоснование носит скорее оправдательный характер, вызванный потребностью сгладить нанесенный подчиненному вред. Ведь у подчиненного нет выбора, решение принимается без него. Можно предположить, что данный руководитель достигает таким способом определенного компромисса в конфликте между утилитарной (ориентация на успех фирмы и свой личный успех) и гуманистической (забота о людях) этикой. Причем важно то, что респондент постоянно апеллирует именно к моральному, а не эмоциональному удовлетворению. Он подчеркивает рациональность, обоснованность принимаемых им решений, а не то, какие эмоции они вызовут у подчиненных. В этом и реализуется принцип приоритета задачи над отношениями. Цели фирмы ставятся выше индивидуальных. Поэтому здесь речь идет уже не об удовольствии, а о долге, как для руководителя, так и для подчиненного. Респондент допускает, что его приказы иногда могут вызывать неудовольствие у подчиненных, особенно если эти распоряжения продиктованы критическими ситуациями и потому являются неожиданными для подчиненных. Однако он не считает подобные действия агрессивными практиками: ведь он же действует не в своих личных интересах, он не «самодур», он в первую очередь заботится об интересах фирмы. По его мнению, подчиненные должны это понимать и удовлетворяться теми объяснениями, которыми он сопровождает неприятные для них решения. Фактически он требует от подчиненных преданности делу, чтобы они, как и он, ставили интересы фирмы выше личных. Правда, как он сам выразился: «Моя фирма - это я», а следовательно, интересы его фирмы - это его личные интересы.

\section{Причины использования агрессивных практик}

Руководители данной организации видят разные причины использования агрессии в управленческой деятельности, однако оба они подчеркивают психологические характеристики и ценностные представления руководителя. На вопрос «Как Вы считаете, с чем связано агрессивное руководство, каковы его причины?» были получены следующие ответы.

«Невоспитанностью и личными причинами. Например, если начальник самодур, то он и замов подберет таких же. Но если орать на человека, то он работать хорошо не будет и в коние кониов уйдет в другое место».

«Причины могут быть любыми. От того, что недоспал или переспал, какие-то личные дела. От воспитания зависит человека. Есть коммерсанты, ребята трудятся, пашут с утра до вечера, до 12 часов ночи. Человек очень устает, поэтому может где-то и сорваться, сильное перенапряжение. ...Сейчас, хоть и есть возможность заработать, но очень высокое напряжение, которое постоянно давит. Может, отражаются на людях вот эти скачки доллара, неопределенность статуса коммерческих структур, налоги и т.n.».

Если говорить о том, что утилитарная этика господствует в современном российском бизнесе, можно предположить, что успешные руководители действуют согласно стратегии «разумного эгоизма». В соответствии с этой стратегией использование гуманистической этики оправдано настолько, насколько ее применение полезно для дела.

\section{Агрессивный менеджмент как стратегия успеха}

Описывая последствия агрессивного руководства для организации, в которой оно практикуется, респондент (заместитель) обозначил его как специфическую стратегию 
поведения в условиях выживания, «дикого» рынка, когда между субъектами рыночного взаимодействия отсутствуют какие бы то ни было отношения доверия.

«Можно идти по трупам в достижении своей иели. "В бизнесе друзей не бывает, - как мне один человек сказал, - в бизнесе есть только партнеры”. Занимаясь одним бизнесом, если он только партнер, то он может “съесть” своего партнера, сильный - более слабого. Пусть это считается агрессивным стилем руководства, человек идет к своей иели, хочет больше и больше».

Интересно, что, по мнению данного руководителя, в бизнесе должны быть не только партнерские, но и дружеские отношения. Последние, в сущности, выполняют функцию неформального контроля, социальной власти, основанной на разделяемом всеми участниками взаимодействия признании общечеловеческих ценностей. Именно такие неформальные ценности и отношения способны послужить ограничителем для действия принципа экономической выгоды. Оценивая состояние современного российского общества, он отметил:

Р.: В нашем так называемом демократическом обществе такой приниип $и$ существует. Человек, который рвется к власти, он таким образом и действует в основном. ...Сейчас это распространенное явление.

И.: А в бизнесе?

Р.: Дело не в том. Структура одинаковая. Как устроено все общество, так устроен и бизнес. Например, если бы государство не воровало, то и в бизнесе не воровали бы.

Несмотря на столь негативную оценку современного состояния дел, оба руководителя отмечают, что, в общем, существует тенденция ухода агрессивных отношений из бизнеса.

«Эти отношения постепенно уходят, хотя частные случаи встречаются. Например, у меня есть знакомый, он действует как компьютер, без эмочий. Он “подминает” под себя подчиненных, если кто с ним не согласен, “обливает грязью”. Но, в общем, сейчас есть выбор. Люди уходят к тем, у кого конструктивный стиль общения».

«Сейчас, в основном, проблемы решаются за “кругльм столом”».

\section{Кейс №2. Культура рефлексивной ответственности (Агентство профессионального сервиса)}

\section{Структура организации, власти и организационная культура}

Исследуемая фирма образована в 1993 г. и занимается управленческим консультированием, «вопросами организационного строительства, организационного развития». Число сотрудников фирмы - порядка 30 человек (точной цифры названо не было). В отличие от первой фирмы, это агентство является комплексной организацией, состоящей из трех структурных подразделений: экономической службы, которая занимается продажами, маркетингом; отдела разработчиков, где работают специалисты, выполняющие разного рода аналитическую и проектную работу; отдела менеджеров, которые организуют работу, разрабатывают идеи, строят отношения с клиентами. Причем, по словам одного из ее директоров, фирма постоянно растет, и ее структура постоянно меняется.

Топ-менеджмент данного предприятия представлен тремя директорами-соучредителями. Каждый из них имеет собственные функциональные обязанности (академический директор, производственный директор и генеральный директор), а в определенных случаях они объединяются в команду для творческого решения задач развития организации. 
«Есть такая форма, называемая содиректорат. Она применяется, когда организаџия небольшая и когда идет интенсивное развитие. Когда требуется, с одной стороны, сконцентрировать достаточно мощный творческий потенциал, а с другой - когда нужно параллельно выстраивать процедурную часть деятельности. В организационном развитии один из важнейших принципов, который нужно строго соблюдать, - это четко разделять развитие и функционирование организаџии. Поэтому у нас и возникла такая система управления, когда есть содиректорат. В рамках этого содиректората есть творческая группа, которая занимается развитием... Mbl различаем, когда мы творческая группа, а когда-содиректорат».

Характер деятельности организации довольно сложен и требует от работников высокого интеллектуального и личностного потенциала. Интеллектуалоемкий труд, научноисследовательские разработки накладывают отпечаток и на характер внутриорганизационных отношений, построение определенного типа организационной культуры.

«У нас ответственность сконцентрирована в больщей степени на человеке, а не на организачии. Степень компетентности и индивидуальной ответственности каждого специалиста и менеджера предельно высока. У нас нет возможности контролировать каждого, следить за графиком ежедневной работы, это в принципе невозможно. Поэтому у нас каждый человек - это такая минилаборатория и минипредприятие. Поэтому отношения у нас строятся по принцииу гиперответственности каждого, это с одной стороны. А с другой - это строгое выполнение графика работ».

Источник рекрутирования персонала для данной организации - элитные вузы Москвы.

«...При приеме на работу мы смотрим не столько на образование человека, техническое или гуманитарное, а на склонности, на опыт. Всегда человек к нам приходит из элитного вуза, при этом мы его еще год готовим у себя».

В отличие от армии как социального института, институт высшего образования предполагает гораздо более развитые ценности рациональности, личной ответственности и самоконтроля, рефлексивности индивида по поводу личной биографии, социального окружения, профессии. Эти же ценности интенсивно эксплуатируются и в исследуемой фирме. Соответственно, культуру данной организации можно условно определить как «культуру рефлексивной ответственности», противопоставив ее «культуре дисциплины», к которой была отнесена организация первого типа. Если в первом случае дисциплина понимается как подчинение приказу и строгое выполнение инструкций начальства, то во втором случае самодисциплина является результатом осознания индивидом необходимости тех или иных действий, значения, которое они имеют для него и для функционирования организации (отдела). В соответствии с этим индивид выстраивает внутреннюю систему контроля за исполнением обязанностей, лежащих в сфере его ответственности.

«Каждый сотрудник нашей организачии должен находиться в субъектной позиции. Это означает, что он должен осознавать, чего он хочет по отночению к нашей организации, $\kappa$ позиции, деятельности и т.д. А во-вторых, он должен себе представлять, как он это хотение будет реализовывать. Это один принщип. Второй принции состоит в следующем. У нас есть представление о том, как мы работаем, чем занимаемся, каковы взаимодействия в нашей организации. Значит, человек должен понять это и руководствоваться этими подходами и принципами. Если где-то он расходится со значимой для нас позицией, то либо он должен измениться, либо ему придется уйти от Hac».

Однако второй принцип, сформулированный данным руководителем, не означает, что организация имеет жесткую, раз и навсегда фиксированную структуру функциональных 
позиций, а человек является в ней всего лишь безликим исполнителем. По словам опрошенных руководителей, организация открыта для инноваций, источником которых может стать любой ее член.

«...Человек должен проявить себя. У нас люди, которые “ни рыба, ни мясо” не выживают, то есть люди, которые приходят для того, чтобы просто отсидеть рабочее время, вряд ли займут достойное место на нашей штатной лестнице, и даже недостойное».

«...Если ты пришел, и у тебя есть своя концепщия, то ты можешь работать в ней, но должен соотнести ее с нашей технологией. Соотнеси свое с тем, что мы делаем, и когда ты соотнес, тогда начинай применять».

Чтобы попасть в данную организацию, человек должен пройти три стадии адаптации: испытательный срок; профессиональное освоение имеющегося; работа в рамках своей сферы ответственности, выполнение тех функций и ролей, которые человек на себя принял. Вероятно, именно благодаря такой тщательной «притирке» организации и «новобранца» формируется довольно устойчивая система отношений внутри фирмы, достигается высокий уровень согласия между руководством и подчиненными. Фактически руководство данной организации проводит политику выстраивания общности интересов еще в процессе рекрутирования персонала. Те, чьи интересы не совпадают с интересами фирмы, отсеиваются еще на стадии адаптации. В результате в этом агентстве фактически отсутствует практика увольнения.

«...Наказания в виде увольнения за что-либо - пока у нас практики такой не было, хотя я как руководитель, администратор, не отрицаю такой возможности. Если что-нибудь произойдет принципиально для нас значимое, то вполне возможно и такое решение».

Однако все сказанное не означает, что в организации не существует конфликтов и что люди не уходят из нее. Напротив, руководство прекрасно осознает неизбежность конфликтов и относится к ним спокойно, рационально.

«У нас были случаи, когда человек уходил с испьтательного срока или со стажировки, потому что либо себя не проявил, либо проявил в такой агрессивной позиции. Агрессивной в том смысле, что он как бы игнорирует установленные правила и позиции или устанавливаемые правила и позиции. Значит, в этом случае разговор у нас обычно бывает прямой: "Мы Вас не понимаем. Мы видим, что Bы как-то сформировали свое представление о нас, поэтому предлагаем срок стажировки продлить. У Вас есть решение, либо Вы согласитесь с этим, либо мы с Вами расстаемся”.

Ориентации руководства данной организации можно определить как партнерские - по крайней мере, в сравнении с патерналистскими тенденциями, имеющими место в первой проанализированной нами фирме. Кроме того, структура власти в этой фирме имеет иной характер. Если в первом случае мы наблюдали явно выраженную концентрацию власти в руках генерального директора, то во втором случае власть гораздо более децентрализована. В целом, структура согласия в организации носит утилитарный характер. Неформальные отношения между руководством и подчиненными имеют место, что проявляется, в частности, в традиции совместного проведения каких-либо праздничных мероприятий, как официальных, так и неофициальных. Однако такие мероприятия рассматриваются не только как дань традиции, но и как возможность оптимизировать деятельность фирмы за счет лучшего понимания личностного потенциала работников, раскрывающегося на таких неформальных событиях. В силу того, что организация является комплексной, содержащей различные профессиональные и статусные позиции, в ней существует возможность вертикальной и горизонтальной мобильности. Это позволяет осуществлять символический контроль за счет 
использования таких средств, как престиж, возможность творческой самореализации и др., т.е. за счет средств, отсутствующих в организации первого типа.

\section{Руководитель - человек надорганизационный}

Интересные данные были получены в интервью относительно того, что составляет суть руководителя, делает человека «настоящим» руководителем, отличает руководителя от не-руководителя. Здесь респонденты сформулировали характеристики, которые описывают, в целом, два типа руководителей. Первый тип можно условно назвать «руководитель-создатель» (собственник), а второй - «руководитель-исполнитель» (менеджер). Причем их следует различать не столько по их статусу или занимаемой ими позиции, сколько по их способностям.

«Руководитель всегда думает о будущем, находится над организаџией, а не в организачии. Говорить о том, что руководитель - это тот, который наверху, а подчиненный-тот, который внизу, бессмысленно».

«Он должен иметь достаточно компетенции, полномочий, он умеет мотивировать людец̌».

«...Руководитель всегда должен нести некий интерес, некую идею, позищию, которая должна реализовываться в деятельности руководимой им организаџии. Т.е. это всегда надорганизационная позиция. Руководитель должен понимать, кому и зачем нужна деятельность его организации, т.е. он должен видеть место своей организации в ее системном окружении».

Первый тип руководителя способен создавать организации (очень часто «с нуля»), мыслить творчески, выходя за рамки общепринятых правил и стереотипов, второй же должен быть хорошим профессионалом, способным обеспечить воспроизводство и развитие созданной организации. Поведение первого характеризуется непредсказуемостью, способностью адекватно реагировать на изменение ситуации. Деятельность второго предсказуема и строится в рамках определенных профессиональных обязанностей и организационной культуры предприятия, на базе которых формируется фиксированный стиль руководства.

«Все успешные руководители, у них одна из принципиальных характеристик - это адекватность ситуации. Если ты неадекватен ситуации, то ты несешь экономические, личные и все прочие потери. Они адекватны, потому они и богаты. Моностильность это удел исполнителя, который существует в стабильных условиях, которые для него поставили и удерживают. Он на этих условиях формирует стиль».

\section{Агрессия: определение, причины, обоснования}

Определяя агрессивный стиль управления, руководители данной фирмы, так же, как и ранее генеральный директор ЧОПа, провели различие между позитивной и негативной функцией агрессии. Все они отметили, что как таковая она имеет место в управленческой деятельности любого руководителя, однако определили ряд условий ее использования. Как отметил один из директоров предприятия:

«С точки зрения управления, формы проявления агрессии, я считаю, необходимы, но они должны иметь гранищы. Вопрос должен идти о гранищах проявления агрессии управленцем, а не о том, хорошо это или плохо».

Определения агрессивного руководства в данном случае, в сущности, не отличаются от тех, что были даны руководителями первой фирмы. Все эти дефиниции сводятся к утверждению, что агрессия - это поведение, разрушающее определенный социальный 
порядок данной организации, т.е. угрожающее существованию самой организации, либо действие, причиняющее вред конкретным участникам или группам данной организации.

«...Такая форма отношений с людьми, когда давящий агрессивно навязывает свою точку зрения».

В любом случае, агрессивные действия воспринимаются как угроза теми, по отношению к кому они направлены.

«Агрессия - это всегда угроза. Агрессия - это угроза твоим интересам».

Однако данные руководители говорят и о том, что без проявлений агрессии отношения в фирме просто немыслимы. При этом следует четко различать агрессивный стиль руководства и агрессивные практики, понимаемые как определенные инструменты воздействия на подчиненных (руководители часто не рассматривают такие практики как примеры агрессивного менеджмента.) Подобные инструменты могут выполнять различные функции. Материалы интервью позволяют выделить, во-первых, функцию мотивации и привлечения внимания.

«Повыменный голос, может, даже крик где-то, резкое отношение, высказывания относительно поведения и поступков, совершаемых тем или иным человеком. Это все ситуационные вещи, они не относятся к агрессии, потому что иногда либо ситуация этого требует, либо люди, с которыми ты работаешь. Они просто не воспринимают информационно не воспринимают $u$ значимость чего-то не воспринимают. Эмоциональная окраска поведения формирует определенное отношение к тому, о чем говорят. По крайней мере, конщентрируется внимание на этом, и формируется определенное отношение, что мимо этого пройти нельзя. Такие вещи - они вряд ли связаны с агрессивностью. Кричи, не кричи - это все процессы, связанные совсем с другим. Смысл крика - обращать внимание на тобой высказанную идею».

Вторая функция - воспитательная. Использование различного рода санкций (формальных и неформальных) в тех случаях, когда никакие иные либеральные средства не оказывают нужного воздействия на подчиненного.

«Ну, например, я, являясь директором этой фирмь, бухгалтеру три раза объяснил, но вижу, что не доходит. Ну, и я имитирую раздраженно-агрессивное поведение, при этом, я так, ну где-то раздражение есть, но оно совершенно контролируемо, перехожу на жесткий тон. Достаточно, если совсем достали, - на «Вы», жестко выговариваю. В результате - слезы. То, что бухгалтером это воспринимается как агрессия, это однозначно. Она меня таким видит. Смотришь - дошло. Ну, поревела. На следуюший день вроде... Но это не на каждый день, это связано только с вопросами принципиальной угрозы мне лично, ей лично, интересам фирмы, из-за того, что она деньги хранит не так, финансовые документы бросает где попало и все прочее. Ну, то есть, это надо жестко просто поступить, что бы это закрепилось».

Помимо такого инструментального использования агрессии, была отмечена и другая ее функция (генеральный директор ЧОПа определял ее как наступательность):

«Второй агрессивный стиль руководства - это когда энергично строятся отношения, $u$ руководимая организация начинает вести себя агрессивно. В короткие сроки, в четких формулировках, на ясных схемах, при подготовленных планах, каждому раздается с объяснениями. Это такой энергичный нормальный административный стиль».

Данный руководитель отметил, что подобный стиль полезен, когда организация еще совсем молодая и руководителю необходимо проводить свою волю, без чего ни одна организация развиваться не будет; этот стиль также полезен в кризисных ситуациях, когда на обсуждения нет времени. 
Все три руководителя исследуемого агентства сошлись во мнении относительно того, что агрессия в управленческой деятельности не может быть средством на каждый день, в противном случае нужно говорить о какой-либо ненормальности (психической или нравственной) менеджера, использующего агрессию в качестве управленческого стиля. Как отметил один из директоров:

«Агрессия - это очень энергозатратное поведение, и нормальный человек не может постоянно вести себя так».

В качестве причины проявления управленцем агрессии (но не как инструментальной практики) все руководители, опять же единогласно, назвали непонимание, неотрефлексированность руководителем того, что он делает, и того, какие последствия его действия имеют для фирмы, непонимание процессов, происходящих в организации. Иначе говоря, речь идет о непрофессионализме и о неразвитости у руководителя саморефлексии.

«А когда это все бестолково, не подготовлено ничего, люди не понимают, что им надо делать, то может вылезти агрессия руководителя, который обиду на свою бестолковость переносит, списывает на бестолковость своего окружения».

\section{Выводы}

Один из основных выводов, который можно сделать на основе проведенных интервью, заключается в следующем. Необходимо различать «деструктивных» руководителей («самодуров» и некомпетентных менеджеров), для которых организация является средством достижения личных интересов, а нужды и самочувствие персонала их совершенно не заботят, и «конструктивных» руководителей, которые заботятся не только о своей выгоде, но и об интересах людей, работающих на них. И те, и другие могут быть успешными предпринимателями, однако время деструктивных руководителей проходит, так как подобные агрессивные стратегии ведения бизнеса и построения внутриорганизационных отношений становятся неадекватными. Хотя в деловых отношениях оба типа руководителей руководствуются утилитарной этикой ${ }^{4}$, конструктивные руководители, в отличие от деструктивных, видят позитивный потенциал использования этических принципов в работе с персоналом и ведении бизнеса. Можно сказать, что деструктивные менеджеры живут сегодняшним днем, а конструктивные ориентируются на будущее, на развитие бизнеса. Оба типа менеджеров используют в своей деятельности агрессивные практики, но у деструктивных руководителей они являются стилевыми характеристиками, способом построения внутриорганизационной политики, а у конструктивных эти практики становятся вспомогательным средством, обеспечивающим успешность функционирования организации. Руководители второго типа предпочитают неагрессивные способы взаимодействия с персоналом.

Следующий вывод по результатам исследования заключается в том, что в каждой организации существуют определенные агрессивные практики, которые не воспринимаются руководством в качестве таковых. Точнее говоря, в интервью

\footnotetext{
4 Здесь можно не согласиться с выводами исследований, проведенных под руководством А.Е. Чириковой [Чирикова 1997], согласно которым утилитарный подход к оценке действующих мотивов предпринимательской деятельности неправомерен. Утилитаризм предполагает ориентацию не только на материальную выгоду, но и на успех как конечный результат. Конечно, каждый руководитель как личность имеет систему интериоризованных моральных ценностей, которые оказывают влияние на его профессиональную деятельность, однако сама профессиональная деятельность делает необходимым использование именно утилитарной этики как наиболее реалистичного основания построения бизнес-стратегий в современном обществе.
} 
руководители относили подобные практики к агрессивным, но, как правило, отмечали, что подобная агрессия носит исключительно инструментальный характер. Она применяется ими вполне осознанно, как практика, позволяющая адекватно решать какие-то частные задачи. По всей видимости, именно этот факт объясняет ту неохоту, с которой опрошенные руководители определяли такие действия как агрессивные. Обычно это различного рода санкции формального и неформального характера (выговоры, крик, оскорбления, невербальные проявления в виде различных жестов или действий и т.п.).

Особенно бурная эмоциональная реакция, с которой один из респондентов постоянно акцентировал необходимость безоценочного отношения к подобного рода агрессии, может свидетельствовать о наличии определенного морального конфликта, заключающегося в столкновении традиционных гуманистических ценностей (согласно которым агрессия имеет негативный смысл) с ценностями утилитаризма. Причем, обосновывая свои действия утилитарными причинами, рациональной правильностью принимаемых решений, менеджеры считают, что используемые ими время от времени агрессивные практики, по сути дела, полезны и для самих подчиненных, по отношению к которым эти практики применяются.

Исходя из материалов интервью такую позицию можно объяснить следующим образом. Высокая степень неопределенности и агрессивности организационного окружения требует от руководителя и руководимой им организации быстрых, четких и правильных действий. Однако человеческий фактор может препятствовать этому. Конкретно, речь идет о тех случаях, когда подчиненному не достает понимания своих обязательств, а следовательно, и ответственного отношения к ним. Под пониманием подразумевается не столько профессиональная компетентность, сколько способность думать, принимать адекватные ситуации решения. Понимание в таком смысле слова предполагает наличие у человека реалистичного взгляда на вещи, развитых аналитических способностей и саморефлексии. Подобные качества формируются в либеральных обществах, одной из основ которых является утилитарная этика.

Тоталитарный режим, господствовавший до недавнего времени в нашей стране, способствовал формированию дисциплинарного типа личности, образом которого в трудовой сфере является рабочий-«патерналист». Основной чертой такого рабочего является делегирование ответственности за собственную жизнь, за принимаемые им решения какой-либо вышестоящей инстанции (начальнику или структуре). Человек с таким типом личности способен эффективно действовать только в стабильных условиях с жестко определенными, ясно очерченными границами, устанавливаемыми для него кем-то извне. Возрастание неопределенности в среде его существования снижает эффективность его деятельности и общую адаптационную способность. Формирование нового социального типа личности - процесс долгий и сложный. В результате, на современных государственных и частных предприятиях заняты люди, в той или иной степени несущие в себе черты дисциплинарной личности.

Руководители, сталкиваясь с проявлениями подобных черт (на уровне стереотипов сознания, поведенческих паттернов) в своих работниках, вынуждены предпринимать какие-то меры воздействия для изменения (разрушения) этих стереотипов, препятствующих эффективному исполнению работником своих обязанностей. Стереотипы, являющиеся крайне устойчивыми образованиями, можно изменить либо в результате длительной работы по их критическому осмыслению, либо в результате переживания человеком кризисных ситуаций, выход из которых - только в отказе от привычных и выработке новых моделей поведения. В этом смысле агрессия руководителя может служить одним из средств создания таких кризисных ситуаций для подчиненного. Однако агрессивные практики, с этой точки зрения, эффективны только в тех случаях, когда руководитель объясняет подчиненному причины их использования и формулирует ему более эффективную поведенческую модель или нормативный образец. Таким 
образом, можно говорить о том, что агрессивные управленческие практики являются одним из необходимых условий формирования новой этики трудовых отношений, которая, по мнению Г.Л. Тульчинского, «является своеобразным практическим ориентиром-образцом для нравственной культуры других сфер общественной жизни» ${ }^{5}$.

На основе этих рассуждений можно заключить, что в частных организациях с жесткой иерархией власти и культурой дисциплины агрессивные практики руководителя в значительной мере носят тот же характер, что и в любой тоталитарной организации: это санкции, обеспечивающие воспроизводство существующего порядка, структуры организации, беспрекословное подчинение руководителю предприятия. Однако тот факт, что предприятие является частным и действует в условиях рыночной конкуренции, накладывает свой отпечаток и на характер власти, делая ее более «прозрачной» для подчиненных. Эти выводы относятся к первой организации, проанализированной в данном исследовании (Частное охранное предприятие): здесь руководитель стремится сделать свою позицию понятной для подчиненных.

В тех организациях, которые имеют тенденцию практиковать партнерские отношения между руководством и персоналом, предъявляют высокие требования к интеллектуальному и личностному развитию своих сотрудников, стремятся к децентрализации власти и формируют культуру рефлексивной ответственности, агрессивные практики руководства носят иной характер. Здесь они в большей степени ориентированы не столько на прояснение для подчиненных позиции руководителя, сколько на формирование собственной осознанной позиции подчиненного в отношении выполняемой им деятельности.

Основной вывод представленной работы заключается в том, что агрессивные управленческие практики являются одним из ресурсов менеджеров, руководствующихся принципами утилитаризма, в формировании нового субъекта социально-экономических отношений. Использование подобных практик обусловлено, с одной стороны, макросоциальными переходными процессами современного российского общества, а с другой - принципами организации и функционирования человеческого сознания. Любые трансформационные процессы предполагают преодоление сопротивления и разрушение старого. Чем интенсивнее такие процессы в обществе, тем острее противоречия и конфликты, возникающие между теми, кто внедряет новое, и теми, кто является носителями отживших, устаревших стереотипов и поведенческих паттернов. Рассматривая менеджмент как одну из наиболее реалистично настроенных, динамичных социальных групп, мы предположили, что именно менеджеры чаще всего сталкиваются в своей деятельности с не отвечающими реалиям сегодняшнего дня ценностными и поведенческими моделями как общества в целом, так и отдельных его представителей. Однако ориентация на успех дела заставляет менеджеров преодолевать подобные препятствия всеми возможными способами, что зачастую и приводит к использованию агрессивных практик. Таким образом, решая конкретные организационные задачи, менеджеры вольно или невольно становятся агентами трансформации этических норм и ценностей современного общества.

А. Этциони [Этциони 1999] утверждает, что либеральное общество, в котором степень социального порядка ограничена и которое полагается на рыночные механизмы, прибегает в основном к прагматическим средствам. В здоровом коммунитарном обществе

${ }^{5}$ Тульчинский Г.Л. Этика бизнеса в современной России // Оправдание морали. Сборник научных статей. К 70-летию профессора Ю.В. Согомонова. Отв. ред. В.И. Бакштановский и А.Ю. Согомонов. Москва-Тюмень: Издание центра прикладной этики и НИИ прикладной этики ТюмГНГУ, 2000. С. 167. 
порядок в целом обеспечивается за счет нормативных средств. В этом смысле социальным порядком здорового общества является порядок нравственный. В российском же обществе еще только формируются основы либерального порядка, не говоря уже о порядке нравственном. Это делает особенно актуальным утилитаристский подход, являющийся одной из этических основ либерализма. В соответствии с этой концепцией, хороши все средства, в перспективе способствующие достижению максимальных выгод. Не случайно, что менеджеры (и особенно успешные) как наиболее динамичная социальная группа в своей деятельности в полной мере используют ценности концепции разумного эгоизма.

\section{Библиография}

Алашеев С.Ю. Неформальные отношения в процессе производства: «взгляд изнутри» // Социологические исследования, 1995. № 2. С. 12-18.

Бабаева Л.В., Лапина Г.П. Малый бизнес в России в эпоху экономических реформ. М.: Институт социологии РАН, 1997.

Бунин А.М. Бизнесмены России: 40 историй успеха. М.: Изд-во ОА «ОКО», 1994.

Душацкий Л.Е. Ценностно-мотивационные доминанты российских предпринимателей // Социологические исследования, 1999. № 7. С. 91-94.

Перепелкин О.B. Российский предприниматель: штрихи к социальному портрету // Социологические исследования, 1995. № 2. С. 35-40.

Радаев B.B. Четыре способа утверждения авторитета внутри фирмы // Социологический журнал, 1994. № 2. С. 149-156.

Романов П.В. Социологические интерпретации менеджмента: Исследования управления, контроля и организаций в современном обществе. Саратов: Саратовский технический государственный университет, 2000.

Романов П.В. Формальные организации и неформальные отношения: Кейс-стади практик управления в современной России. Саратов: Издательство Саратовского университета, 2000.

Романюк В. Как и чему учить предпринимателей? // Я \& Бизнес, 2001. № 2. С. 62-63.

Российское предпринимательство: стратегия, власть, менеджмент / Под ред. А.Е. Чириковой. М.: Институт социологии РАН, 2000.

Сухиненко Д., Зеленщова А. Переосмысление управления в современном мире. Вызов России. М.: Московская школа политических исследований, 2001.

Темницкий А.Л. Патернализм и партнерство в корпоративной культуре российских компаний / Чирикова A.E. (отв. ред.) Российское предпринимательство: стратегия, власть, менеджмент. С. 56-65.

Чирикова A.E. Деловая женщина в экстремальных ситуациях // Социологические исследования, 1998. № 10. С. 68-76.

Чирикова A.Е. Лидеры российского предпринимательства: менталитет, смыслы, ценности. Москва: Институт социологии РАН, 1997.

Чирикова А.Е., Кричевская О.Н. Женщина-руководитель: деловые стратегии и образ «я» // Социологические исследования, 2000. № 11. С. 45-57.

Этияиони А. Новое золотое правило. Сообщество и нравственность в демократическом обществе / Иноземиев В.Л. (ред.) Новая постиндустриальная волна на Западе. Антология. М.: Academia, 1999. С. 309-334. 


\title{
Профессиональные обзоры
}

$\boldsymbol{V} \boldsymbol{R}$ Предлагается очень интересный для нас материал - «Экономическая социология в Венгрии», переведенный из Европейского Ньюслеттера «Экономическая социология» (автор - А. Рона-Тас). Венгерская экономическая социология по праву занимала лидирующее положение в странах Центральной и Восточной Европы. Их опыт очень важен для нас. А даваемые автором (венгром, проживающим в США) трезвые оценки невольно заставляют задуматься о наших собственных проблемах.

\section{ЭКОНОМИЧЕСКАЯ СОЦИОЛОГИЯ В ЕВРОПЕ: ВЕНГРИЯ ${ }^{1}$}

\author{
Акос Рона-Tac [Ákos Róna-Tas] \\ Университет Калифорнии в Сан-Диего \\ Email: aronatas@ucsd.edu
}

Перевод М.С. Добряковой

Научное редактирование - В.В. Радаев

Эмпирическая социология в Венгрии всегда более вдохновлялась проблемами, нежели теориями. Если же эмпирические работы и следовали теории в годы социализма, то, хотя и не впрямую, это был марксизм: он обращал внимание на вопросы, порождавшиеся практиками, которые, как считалось, коренились в марксистской теории.

Социализм был особой формой социального устройства, легитимность которого практически целиком основывалась на утверждении, что данное социальное устройство превосходит капитализм. Выдвигались даже критерии измерения этого превосходства. Равенство, материальное процветание, справедливость, отсутствие фундаментальных социальных различий, рациональность - вот лишь некоторые из благ, обещанных социализмом. В результате всякое исследование, ставившее под вопрос успехи социализма в достижении этих целей, тем самым подвергало сомнению и легитимность находящейся в его основе социальной системы. Ныне не так очевидно, почему эти режимы столь болезненно реагировали, например, на то, что тот или иной социолог вдруг публиковал результаты исследования бедности или статью о вкладе домохозяйств в сельскохозяйственное производство - в то время как большинство людей прекрасно знали о существовании бедности, а миллионы - выращивали на заднем дворе собственные помидоры и морковь. Однако поскольку единственным обоснованием социализма было осознание его превосходства (а последнее предполагало его способность искоренить бедность и наладить эффективное крупномасштабное сельскохозяйственное производство), эти исследования неявно поднимали фундаментальные вопросы о социальной системе в целом. Таким образом, при социализме плоды социальных наук воспринимались небезразличным образом.

Поскольку публичная сфера была полна ограничений и находилась под неусыпным контролем партийного государства, пространством для публичного дискурса стала социология. В своих публикациях социология обращалась не только к академическому сообществу, но и ко всей образованной публике в целом. Социологические труды мгновенно расходились не только среди других социологов и бдительных партийных

1 Переведено по: Róna-Tas, Ákos. Economic Sociology in Europe: Hungary, Economic Sociology. European Electronic Newsletter (February 2002). Vol. 3, No. 2. http://www.siswo.uva.nl/ES/esfeb02art4.html. 
работников, но и среди физиков, инженеров, врачей, школьных учителей и творческой интеллигенции. Статьи, которые сегодня выходили бы под маркой политической журналистики, публиковались в жанре социальных наук, оформлялись необходимыми примечаниями, библиографией и теоретическими ссылками. Дискуссии велись не столько по поводу методологии или теоретических нюансов, сколько по поводу политического подтекста написанного.

До 1989 г. между социальными дисциплинами не было четкой дифференциации. Экономическая теория, политология (называвшаяся тогда наукой о государстве и праве) и социология занимались тем, чтобы отделить себя от своих марксистских собратьев политэкономии, научного социализма, диалектического и исторического материализма [Bockman 1999]. Институциональные войны за сферу влияния в университетах, исследовательских институтах, в Венгерской академии наук, дебаты по поводу программы социальных наук для средней школы велись вокруг этой идеологической границы, а не между дисциплинами.

C концом государственного социализма в области этих дисциплин произошли радикальные изменения. Марксизм, некогда тяжело довлевший над ними, затонул, подобно Атлантиде, не оставив и следа. Появилась свободная публичная сфера, где политический дискурс уже не должен был маскироваться под социальную науку. Некоторые обществоведы начали делать карьеру в политике или в области экспертизы. Социальные науки больше сосредоточились на себе, больше внимания стали уделять методологии. С падением Берлинской стены и железного занавеса западные идеи и модели социальных наук наводнили Венгрию, и в последнее время дисциплинарные границы начали укрепляться академическими вариантами колючей проволоки и минных полей.

\section{Экономическая социология до 1989 г.}

В отличие от США, где экономическая социология развивалась в форме явного или скрытого спора-соперничества с экономической теорией, венгерская экономическая социология исторически никогда не враждовала с экономической теорией. Когда две эти силы объединились в своей критике марксизма, дисциплинарная граница между ними стала почти незаметной. Поскольку регулярной университетской подготовки социологов не велось до середины 1960-х гг., некоторые социологи получили ученую степень в области экономической теории. Беспрепятственный переход из экономики в социологию и обратно облегчался еще и тем фактом, что венгерские экономисты, помимо прочего, приняли традиции институционализма и эмпиризма. Они не особенно интересовались дедуктивным моделированием, а если и интересовались, то в центре их внимания были институциональные образования государственного социализма [Kornai 1980]. Их модели вскрывали дисфункции [malfunctions] социалистических институтов. Я.Корнаи - пожалуй, самый известный экономист социализма - считал социалистическую экономику частью социально-политико-экономической системы [social-political-economic system] [Kornai 1992].

В последние десятилетия государственного социализма венгерская экономическая социология сложилась в качестве достаточно динамичной области знания, и в ее рамках были написаны одни из лучших социологических работ в данном регионе. Это было время периодических экспериментов в сфере экономической и, в меньшей степени, политической либерализации. Относительная открытость венгерского варианта позднего социализма позволяла западным исследователям работать в Венгрии, а венгерским ученым - выезжать за границу. Венгерская экономическая социология интегрировалась в западное академическое сообщество, и, по крайней мере, в США, Венгрия стала играть роль одной из призм, через которые исследовался государственный социализм. Например, 
работы Ивана Селеньи [Ivan Szelenyi], Дэвида Старка [David Stark], Майкла Буравого [Michael Burawoy] позволили выстроить надежную связь между исследованиями в Венгрии и дебатами в американской социологии. Британские социологи - такие, как Найджел Суэйн [Nigel Swain] и Крис Хан [Chris Hahn] - также обращались к исследованию Венгрии. Все это привело к тому, что в англо-говорящем мире специфический опыт данной небольшой страны стал оказывать непропорционально большое влияние на интерпретации посткоммунистической экономической трансформации не только в Центральной Европе, но также в России и даже в Китае [Kennedy 2001].

В своем кратком и, совершенно очевидно, выборочном обзоре я остановлюсь на четырех основных областях, где венгерская экономическая социология особенно преуспела, а именно: исследования «второй экономики» [the second economy], организации социалистической фирмы, политической экономии планирования и социальной стратификации.

После проведения в начале 1980-х гг. мер по либерализации «вторая экономика» (мелкий, неформальный частный сектор в рамках социализма) стала одной из центральных тем венгерской экономической социологии [cм. Róna-Tas 1997]. Открытие этого мира хозяйства - с его собственной логикой, отличной от той, что господствовала в планируемом и управляемом государством социалистическом хозяйстве, - породило целый ряд исследований, выполненных на мировом уровне. «Вторая экономика» в Венгрии была глубоко укоренена в социальных отношениях и охватывала такие виды деятельности, как личные подсобные хозяйства [Szelenyi 1988; Kovách 1987; Juhász 1988], мелкое ремесленное производство [Kuczi and Vajda 1990], вторичная занятость, мелкая торговля, оказание частных потребительских услуг, частное строительство жилья [Sik 1984], образование мелких деловых товариществ [business partnerships]. Происходившие здесь трансакции должны были полагаться почти исключительно на личные связи и обыденные нормы, так как социалистическое государство неохотно предоставляло какоелибо правовое обеспечение подобной деятельности. Хотя «вторую экономику» часто считали рыночной экономикой [Kemény 1982] и рациональной формой использования труда [Gábor and Galasi 1981], ее фундаментально социологический характер никогда не подвергался сомнению.

В то время как исследования «второй экономики» были сосредоточены на «малых формах», социологи организаций пытались глубже понять работу гигантских социалистических фирм. Здесь исследователей интересовали громадный размер компаний [Schweitzer 1982], процесс труда, трудовые отношения на предприятиях [Héthy and Makó 1989; Burawoy and Lukácz 1992]. Пустив «вторую экономику» в социалистическую фирму в начале 1980-х гг., государство позволило компаниям привлекать на субподрядной основе мелкие деловые товарищества, которые были образованы их собственными работниками внутри фирмы - что делало грань между «первой» и «второй экономикой» весьма размытой [Sziráczky 1989; Stark 1989; Laky 1984].

Выходило также много работ по политэкономии планирования, исходивших из идеи о том, что социалистические фирмы - не просто марионетки в руках плановиков, но обладают определенной автономией [Bauer 1978; Szalai 1989, Voszka 1988]. Они представляли планирование как сложный процесс торга [bargaining], сопровождающегося действием социальных и политических сил, которые часто приводят к непредвиденным последствиям на уровне хозяйственной системы в целом.

Наконец, проводилось много исследований в области социальной стратификации. В основном они были организованы двумя исследовательскими группами: одной руководил Рудольф Андорка [Rudolf Andorka] (Центральное статистическое бюро); другой - Тамаш Колоши [Tamás Kolosi] (сначала в Партийном институте социальных 
исследований, затем - в исследовательском институте $\mathrm{TARKI}^{2}$ ). Первоначально для того, чтобы показать существование системного экономического неравенства, исследователи должны были отказаться от исследования механизмов его появления. Разграничивая социальную стратификацию и социальную структуру, они сосредоточивались на исследовании первой и практически не уделяли внимания второй. В некоторых ранних работах по социальной стратификации напрямую выдвигались марксистские утверждения о социальных классах, однако в последние десятилетия государственного социализма исследователей больше интересовали вопросы социальной мобильности [Simkus and Andorka 1982; Andorka and Kolosi 1984; Kolosi 1987] и экономической дифференциации, в том числе проблемы бедности [Bokor 1986]. К тому времени исследования стратификации уже не обходили стороной поиск механизмов появления неравенства и начали уделять внимание исследованию «второй экономики», процессам на рынке труда [Galasi and Sziráczky 1985] и социальной психологии материальных ожиданий [Tardos 1988].

\section{Постсоциалистическая эпоха}

Распад государственного социализма и начало постсоциалистической трансформации радикально изменили набор проблем, составляющих предметную область венгерской экономической социологии. Прежние формы планирования, «второй экономики» и социалистической фирмы исчезли, уступив центральное место экономическому переходу к рыночному хозяйству. Исследования организаций уже нацелены на выявление того, как компании адаптируются к радикально изменившейся среде с точки зрения своей внутренней организации [Whitley and Czabán 1998], процесса труда [Czabán and Whitley 1998], поведения, основанного на принципах сотрудничества [Casbina and Leveleki 2000; Gal 2000], уплаты налогов [Tóth and Semjén 1998], а также того, как все это влияет на успешность компании в целом [Lengyel 1999, 2000]. Много интересных работ выполнено на основе идущего ныне панельного исследования предприятий (оно было начато в 1992 г. и охватывает примерно 400 фирм в обрабатывающей промышленности).

Многие авторы обращаются к исследованию приватизации. Некоторых интересует сам процесс как таковой [Gyukits and Szántó 1998; Stark, 1992, 1996; Antal-Mokos 1998]. Другие исследуют его последствия - такие, как текучесть управленческого состава [Böröcz and Róna-Tas 1995] и формирование сетевых связей между компаниями [Vedres 2000a, 2000b].

Исследование предпринимательства образует еще одну благодарную область исследований. Несмотря на то, что в Венгрии занятие предпринимательством как основной деятельностью - новое явление посткоммунистического периода, исследования малого предпринимательства во многом обязаны более ранним исследованиям «второй экономики». Поскольку рыночные условия либо отсутствовали вовсе, либо были развиты в недостаточной мере, предпринимательство оказывалось глубоко укоренено в социальных отношениях. Длительная исследовательская традиция обращается к анализу природы предпринимательства, описывая работу малых предпринимателей и логику их действий в контексте недостаточно сложившихся рыночных условий [Kuczi 2000; Laki 1998; Róna-Tas 2001; Letenyei 2001]. Другое интересное направление - рекрутирование предпринимателей [Róbert 1996; Róna-Tas 1994; Lengyel 1997-1998]. Здесь рассматривается, какой тип ресурсов или капитала необходимо мобилизовать, чтобы основать предприятие в условиях отсутствия действующего финансового рынка. В значительной степени под влиянием работы Пьера Бурдье о различных формах капитала (культурного, человеческого, социального и политического) [Eyal et al. 1998]

\footnotetext{
${ }^{2}$ Информационный центр социальных исследований [Társadalomkutatási Intézet Rt]. Cм.
} http://www.tarki.hu. - Прим. перев. 
исследователи проанализировали различные способы его мобилизации, необходимой для создания прибыльного предприятия [Róna-Tas 1998].

В то время как исследования процесса рекрутирования предпринимателей сосредоточены на выявлении детерминант экономического успеха, исследования стратификации больше заняты поиском факторов возникновения бедности и все увеличивающейся пропастью между бедными и богатыми. Одним из источников данных об изменениях в области неравенства является начатое в 1992 г. венгерское панельное исследование 2 тыс. домохозяйств на базе случайной выборки [Andorka and Spéder 2001; Spéder 1998]. Отчеты, написанные по этому исследованию, демонстрируют существенное увеличение дифференциации и рост бедности в 1990-е гг. Во многих работах присутствует стремление понять этот процесс путем изучения рынка труда в целом и явлений безработицы, частичной занятости и нетипичной работы в частности.

Наконец, сделана интересная работа о неформальных рынках [Sik 1999; Czakó and Sik 2001] и личных сетях, рассматриваемых как активы [Sik and Wellman 1999].

Исследователями за пределами Венгрии предпринимались попытки разработать более общие теории посткоммунистической трансформации, однако влияние этих теорий в Венгрии весьма ограничено. Эти авторы склонны уделять основное внимание трансформации отношений собственности и делают попытку обнаружения и теоретического обоснования третьего пути - промежуточного варианта между социалистической административно-командной экономикой и рыночным капитализмом [Böröcz 1993; Stark and Bruszt 1997; Eyal et al. 1998].

\section{Общая оценка результатов}

За последнее десятилетие в венгерской экономической социологии произошли важные изменения. Исследовательские институты стали играть более заметную роль в проведении новых исследований, в то время как роль университетов в этом процессе уменьшилась. В период серьезных финансовых затруднений университеты переживают стремительное увеличение набора студентов - по сравнению с 1980-ми гг. количество студентов выросло в 2 раза, причем число тех, кто изучает социологию, возросло в 10 раз. Университеты все в меньшей степени остаются исследовательскими центрами, превращаясь в фабрики по производству дипломированных специалистов [credential factories]. В этих условиях они стремятся укреплять границы своих дисциплин и тем самым противостоять снижению уровня качества. В результате экономическая социология, как и прочие междисциплинарные течения, теряет свои позиции в высшем экономическом образовании. Факультеты экономики безоговорочно следуют неоклассической экономической теории, и счастливые времена сотрудничества экономической теории и экономической социологии уходят в прошлое. Экономисты стремительно теряют интерес к социологии, в то время как со стороны социологов появился - пока незначительный, но все возрастающий - интерес к теории рационального выбора.

Поскольку исследовательские институты все более активно вовлекаются в прикладные исследования, теоретически амбициозных работ - которые, как правило, делаются в ресурсных и исследовательских центрах, - немного, и зачастую они проводятся учеными, занимающими хорошо оплачиваемые позиции в зарубежных университетах. Если в Венгрии исследования и связаны с теорией, то преимущественно это происходит путем проверки заимствованных идей на венгерских данных. А в условиях продолжительного отсутствия интереса к теории в венгерской экономической социологии ведется очень мало дискуссий, и процесс накопления знания идет весьма вяло. Отсутствие связной теоретической схемы явилось одной из многих причин, почему попытки экономической 
социологии сформулировать связный план посткоммунистической хозяйственной трансформации оказались столь неудачными.

Тем не менее, неблагоприятные условия существования венгерской экономической социологии во многих отношениях оказались ей на руку. Утрата массовой аудитории в сочетании с усилением конкуренции с экономической теорией привела к продвижениям в области методологии. Публикуемые работы становятся все более солидными и тщательно сделанными. Вследствие дефицита финансовых средств исследователи зачастую обращаются к иностранным и международным источникам финансирования. А это вынуждает их изучать международную литературу и проводить межнациональные сравнения. Новые работы значительно менее ограничены узко-региональными рамками, чем работы десятилетней давности.

Парадоксально, но самый серьезный вызов для экономической социологии состоит в ее относительной экономической успешности. Сейчас, через двенадцать лет после крушения коммунизма, Венгрия является одним из лучших учеников посткоммунистической трансформации. Начиная с 1960-х гг. Венгрия всегда была страной хозяйственных экспериментов. Разные волны реформ либерализации при социализме превратили Венгрию в образчик рыночного социализма. Радикальное переустройство хозяйства в 1990-е гг. также стимулировало интеллектуальную работу экономических социологов. Постепенная интеграция в Европейский Союз не позволила Венгрии породить новую форму организации своего хозяйства, и страна готовится занять нормальное и, значит, ничем не примечательное место. Венгерская экономическая социология периода позднего социализма пользовалась популярностью и была релевантной; в посткоммунистическую эпоху за ней осталась ее релевантность. И ей еще предстоит найти свое новое место в мире пост-посткоммунистической нормальности.

\section{Библиография}

В работах, обозначенных «звездочкой» $(*)$, есть аннотация на английском языке.

Andorka, Rudolf and Tamás Kolosi (eds.) Stratification and Inequalities. Budapest: Institute for Social Sciences, 1984.

Andorka, Rudolf and Zsolt Spéder. Poverty in Hungary in 1992-1995, in: Lengyel, György and Zsolt Rostoványi (eds.) The Small Transformation. Society, Economy and Politics in Hungary and the New European Architecture. Budapest: Akadémiai Kiadó, 2001. P. 12659

Antal-Mokos, Zoltán. Privatisation, Politics, and Economic Performance in Hungary. Cambridge: Cambridge University Press, 1998.

Bauer, Tamás. Investment Cycles in Planned Economies, Acta Oeconomica (1978). Vol. 28, No. 3-4. P. 422-455.

Bockman, Johanna K. Economists and Social Change: Science, Professional Power, and Politics in Hungary, 1945-1995. Doctoral Dissertation, University of California, San Diego, 1999.

Bokor, Ágnes. Deprivation in Hungary, in: Andorka, Rudolf and László Bertalan (eds.) Economy and Society in Hungary. Budapest: Karl Marx University, 1986. P.185-202.

Böröcz, József. Simulating the Great Transformation: Property Change under Prolonged Informality in Hungary, Archives Européennes de Sociologie (1993). Vol. 34. P. 81-106.

Böröcz, József and Ákos Róna-Tas. Formation of the New Economic Elites: Hungary, Poland and Russia, Theory and Society (1995). Vol. 24, No. 5. P. 751-81. 
Burawoy, Michael and János Lukács. The Radiant Past: Ideology and Reality in Hungary's Road to Capitalism. Chicago: University of Chicago Press, 1992.

Csabina, Zoltán and Magda Leveleki. Vállalatok koopertativ magatartása a hazai feldolgozó iparban (Cooperative behavior of companies in manufacturing)*, Szociológiai Szemle (2000). Vol. 2. P. 51-70.

Czabán, László and Richard Whitley, The Transformation of Work Processes in Emergent Capitalism: The Case of Hungary, Work, Employment and Society (1998). Vol. 12, No. 1. P. 47-72.

Czakó, Ágnes and Endre Sik. Characteristics and Origins of the COMECON Open-Air Market in Hungary, in: Lengyel, György and Zsolt Rostoványi (eds.) The Small Transformation. Society, Economy and Politics in Hungary and the New European Architecture. P. 104123.

Eyal, Gil, Ivan Szelenyi and Eleanor Townsley. Making Capitalism Without Capitalists. The New Ruling Elites in Eastern Europe. L.: Verso, 1998.

Gábor, R. István and Péter Galasi. A «második» gazdaság (The «Second» Economy). Budapest: Közgazdasági és Jogi Kiadó, 1981.

Gál, Róbert Iván. Puha költségvetési korlát, a szerzödések kezelése és a nótorius megbizhatatlanság (Soft budget constraints, the handling of contracts and notorious unreliability)*, Szociológiai Szemle (2000). No. 1. P. 3-23.

Galasi, Péter and György Sziráczki (eds.) Labour Market and Second Economy in Hungary. N.Y.: Campus, 1985.

Gyukits, György and Zoltán Szántó. Privatizáció és társadalmi tőke. Gazdasági folyamatok társadalmi beágyazottsága egy kórházi osztály privatizációs kisérleteinek példáján (Privatization and social capital. The social embeddedness of economic processes in the privatization of a hospital unit)*, Szociológiai Szemle (1998). No. 3. P. 83-98.

Héthy, Lajos and Csaba Makó. Patterns of Workers' Behavior and the Business Enterprise. Budapest: Institute of Sociology of the Hungarian Academy of Sciences, 1989.

Juhász, Pál. Zsákutcában van-e a magyar mezôgazdaság? (Is Hungarian agriculture on a deadend street?), Medvetánc (1988). No. 1. P. 197-211.

Kemény, István. The Unregistered Economy in Hungary, Soviet Studies (1982). Vol. 34, No. 3. P. 349-66.

Kennedy, Michael D. Postcommunist Capitalism, Culture and History, American Journal of Sociology (2001). Vol. 106. No. 4. P. 1138-51.

Kolosi, Tamás. Tagolt társadalom: struktúra, rétegzödés, egyenlötlenség Magyarországon. (Stratified society: structure, stratification and inequality in Hungary). Budapest: Gondolat, 1987.

Kornai, János. Economics of Shortage. Amsterdam: North-Holland, 1980.

Kornai, János. The Socialist System. The Political Economy of Communism. Princeton: Princeton University Press, 1992.

Kovách, Imre. A mezôgazdasági kisárutermelés üzemformái (The types of agricultural smallcommodity production), Szociológia (1987). No. 4. P. 513-53.

Kuczi, Tibor. Kisvállalkozás és társadalmi környezet (Small entrepreneurship and social environment). Budapest: Replika, 2000. 
Kuczi, Tibor and Ágnes Vajda. A kisvállalkozók társadalmi összetétele (The social composition of small entrepreneurs). Budapest: Munkaügyi Kutató Intézet, 1990.

Laki, Mihály. Kisvállalkozás a szocializmus után (Small Enterprise after Socialism). Budapest: Közgazdasági Szemle Alapitvány, 1998.

Laky, Teréz. Small Enterprises in Hungary: Myth and Reality, Acta Oeconomica (1984). Vol. 32, No. 1-2. P. 39-63.

Laky, Teréz. A kisvállalkozások növekedésének korlátai (Limits of growth for small enterprises)*, Szociológiai Szemle (1998). No. 1. P. 23-40.

Lengyel, György. Entrepreneurial Inclinationas in Hungary, 1988-1996, International Journal of Sociology (1997-1998). Vol. 27, No. 4. P. 36-49.

Lengyel György (ed.) Siker, Halasztás, Pénzügyi Fegyelem. A Vállalati Panelvizsgálat Tapasztalataiból (Success, Delay, and Fiscal Discipline. From the Results of the Panel Study of Firms). Budapest: BKE, 1999.

Lengyel, György (ed.) Bizalom, tulajdon, nyereség. A vállalati panelvizsgálat elemzésegazdasági szereplök és magatartások (Trust, Property, Profit. The Analysis of the Panel Study of Firms - Economic Actors and Behavior). Budapest: BKE, 2000.

Letenyei, László. Rural Innovation Chains. Two Examples of the Diffusion of Rural Innovations, Review of Sociology (2001), No. 1. P. 85-100.

Róbert, Péter. Vállalkozók és vállalkozások (Entrepreneurs and enterprises.), in: Andorka, Rudolf, Tamás Kolosi and György Vukovich (eds.) Társadalmi Riport 1996 (Social Report 1996). Budapest: TARKI, 1996.

Róna-Tas, Ákos. The First Shall Be Last? Entrepreneurship and Communist Cadres in the Transition from Socialism, American Journal of Sociology (1994). Vol. 100, No. 1. P. 4069.

Róna-Tas, Ákos. The Great Surprise of the Small Transformation: The Demise of Communism and the Rise of the Private Sector in Hungary. Ann Arbor: University of Michigan Press, 1997.

Róna-Tas, Ákos. Path-Dependence and Capital Theory: Sociology of the Post-Communist Economic Transformation, East European Politics and Societies (Winter 1998). Vol. 12, No. 1. P. 107-131.

Róna-Tas, Ákos. The Worm and the Caterpillar: The Small Private Sector in the Czech Republic, Hungary and Slovakia, in: Bonnell, Victoria and Tom Gold (eds.) The New Entrepreneurs of Europe and Asia: Patterns of Business Development in Russia, Eastern Europe, and China. Armonk, N.Y.: M.E. Sharpe, 2001 (in press).

Schweitzer, Iván. Vállalatnagyság (Firmsize). Budapest: Közgazdasági és Jogi Könyvkiadó, 1982.

Sik, Endre. 'Small is Useful' or the Reciprocal Labour Exchange in Hungary, On Labour Economics. Working Paper No. 5. Budapest: Karl Marx University, 1984.

Sik, Endre. 'Emberpiac' a Moszkva téren ('Slave market' on Moszkva Square)*, Szociológiai Szemle (1999). No. 1. P. 97-119.

Sik, Endre and Barry Wellman. Network Capital in Capitalist, Communist, and Postcommunist Countries, in: Wellman, Barry (ed.) Networks in the Global Village. Life in Contemporary Communities. Boulder, CO: Westview, 1999. P. 225-253.

Simkus, Albert and Rudolf Andorka. Inequalities in Educational Attainment in Hungary, 19231973, American Sociological Review (1982). Vol. 47, No. 6. P. 740-751. 
Spéder, Zsolt. Poverty Dynamics in Hungary during the Transformation, Economics of Transition (1998). Vol. 6, No. 1. P. 1-21.

Stark, David. Coexisting Organizational Forms in Hungary's Emerging Mixed Economy, in: Nee, Victor and David Stark (eds.) Remaking of the Economic Institutions of Socialism: China and Eastern Europe. Stanford: Stanford University Press, 1989. P. 137-68.

Stark, David. Path dependence and Privatization Strategies in East Central Europe, East European Politics and Societies (1992). Vol. 6, No. 1. P. 17-54.

Stark, David. Recombinant Property in east European Capitalism, American Journal of Sociology (1996). Vol. 101. P. 993-1027.

Stark, David and László Bruszt. Postsocialist Pathways: Transforming Politics and Property in East Central Europe. Cambridge: Cambridge University Press, 1997.

Szalai, Erzsébet. Gazdasági mechanizmus, reformtörekvések és nagyvállalati érdekek (Economic mechanism, reform attempts and the interest of large firms). Budapest: Közgazdasági és Jogi Könyvkiadó, 1989.

Szelényi, Iván. Socialist Entrepreneurs. Embourgeoisement in Rural Hungary. Madison: Wisconsin University Press, 1988.

Sziráczki, György. Internal Subcontracting in Hungarian Enterprises, in: Elster, Jon and K.O. Moene (eds.) Alternatives to Capitalism. Cambridge: Cambridge University Press, 1989. P. 39-60.

Tardos, Róbert. Meddig nyújtózdkod(j)unk? (How high do (should) we aspire?) Budapest: Közgazdasági és Jogi Könyvkiadó, 1988.

Tóth, István János and András Semjén. Tax Behaviour and Financial Discipline of Hungarian Enterprises, in: Csaba, László (ed.) The Hungarian SME Sector Development in Comparative Perspective. Budapest: Kopint-Datorg, 1998. P. 103-134.

Vedres, Balázs (a) Constellations of Economic Power, Connections (2000). Vol. 23, No. 1. P. 44-59.

Vedres, Balázs (b) A tulajdonosi hálózatok felbomlása (The dissolution of ownership networks), Közgazdasági Szemle (September 2000). Vol. 47.

Voszka, Éva. Reform és átszervezés a nyolcvanas években (Reform and reorganization in the 1980s). Budapest : Közgazdasági és Jogi Könyvkiadó, 1988.

Whitley, Richard and László Czabán. Institutional Transformation and Enterprise Change in an Emergent Capitalist Economy: The Case of Hungary, Organization Studies (1998). Vol. 19, No. 2. P. 259-28. 
$\boldsymbol{V} \boldsymbol{R}$ Нас ожидает необычный обзор электронных ресурсов. Он подготовлен профессионалом в области электронных библиотечных ресурсов B.В. Писляковым (ГУВШЭ). Из него, в частности, можно узнать, где найти электронные версии ведущих экономико-социологических журналов, и как они представлены в крупных электронных системах библиотечного поиска.

\title{
ЗАРУБЕЖНЫЕ ЭЛЕКТРОННЫЕ ЖУРНАЛЫ ДЛЯ ЭКОНОМСОЦИОЛОГОВ
}

\author{
Писляков Владимир Владимирович \\ Начальник Отдела информационных систем и электронных \\ ресурсов библиотеки ГУ-ВШЭ \\ Email: pislyakov@,hse.ru
}

«Электронные журналы» ${ }^{1}$ - термин, который постепенно входит в обиход российского ученого. Исследователи уже считают работу несовершенной и незавершенной, если не выполнен обзор электронных баз данных по соответствующей тематике, и гуманитарии здесь не исключение. В то же время, однако, не так много специалистов имеют четкое представление о различных видах информационных ресурсов, об их специфике и «контентной политике», о том, что и где имеет смысл искать. Отсутствие методики информационного поиска подчас выливается в ощутимые траты времени впустую, причем необходимый материал может так и остаться необнаруженным.

Поэтому предметные обзоры Интернет-ресурсов, начатые Е. Г. Новиковой в прошлом, девятом номере «Экономической социологии» чрезвычайно полезны для профессиональной аудитории. Наша статья будет иметь несколько иную направленность: мы рассмотрим ресурсы не «открытого Интернета», доступные каждому пользователю сети, а базы данных зарубежной периодики, использование которых основано на подписании лицензионного соглашения с их производителями и внесении некоторой платы. Как правило, «персональное» лицензионное соглашение, заключаемое ученым самостоятельно, оказывается крайне дорогостоящим. По этой причине обычная мировая практика состоит в передаче этой функции библиотеке той учебной или исследовательской организации, сотрудники которой заинтересованы в использовании информационных Интернет-ресурсов периодики. «Корпоративное» приобретение баз данных оказывается намного выгоднее, и именно библиотека формирует в итоге «электронную подписку» своего института, университета, исследовательского центра. При этом доступ к ресурсу имеют как минимум все посетители библиотеки (с библиотечных компьютеров), как максимум - все сотрудники организации (со своих рабочих мест или даже с домашних компьютеров).

Наш обзор состоит из двух частей: сначала мы вкратце опишем различные типы электронных баз данных периодики, существующие в Интернете, затем - возьмем ряд зарубежных социологических журналов и определим, в каких ресурсах и в каком виде они представлены. Исследование будет касаться исключительно контента, «содержимого» баз данных, а не их поисковых возможностей, особенностей интерфейса и т. д.

Для начала, однако, два замечания.

\footnotetext{
${ }^{1}$ Необходимо внести ясность относительно этого термина, часто используемого в двух различных смыслах. Говоря «электронные журналы» в данной статье, мы будем иметь в виду электронные версии печатных периодических изданий. Поэтому за рамками нашего обзора останутся электронные журналы, в принципе не выходящие на бумажном носителе, так называемые «digitally born» (один из примеров - настоящее издание).
} 
В случае «открытого Интернета» серьезной проблемой любого обзора сайтов и любой странички с коллекцией ссылок является возникновение «dead links», «мертвых ссылок», в результате перемещения или исчезновения отрецензированных и рубрицированных ресурсов и, как следствие, устаревание и потеря надежности выполненной работы. Аналогичным образом изменяется наполнение баз данных периодических изданий. Их производители заключают соглашения с издательствами на представление журналов своим пользователям, и при изменении или упразднении соглашений, срок действия которых истек, а также при заключении новых договоров контент баз данных может меняться. Это следует иметь в виду при использовании нашего обзора: сведения о контенте различных систем, приведенные здесь, относятся к апрелю 2002 г.

Второе, что хотелось бы отметить, - это вопрос о доступности электронных систем. Не все рассматриваемые нами далее базы данных имеют широкое распространение в России. Многие университеты и исследовательские институты, особенно в регионах, вообще не имеют электронной подписки. Имеет ли смысл в таких условиях рассказывать о характеристиках нескольких недешевых ресурсов широкому сообществу? Не будет ли этот интерес праздным и не относящимся к реальности? Мы полагаем, что смысл в прочтении нашего обзора все равно есть: ученому важно по крайней мере знать, доступ к каким ресурсам ему жизненно необходим, и ощущать потребность в усовершенствовании своей информационной базы. Умение ориентироваться в поле электронных информационных систем поможет не только выделить время на командировку в организацию, имеющую доступ к наиболее важному и ценному ресурсу, но и правильно распорядиться, например, средствами гранта, предусматривающего информационную поддержку исследовательской деятельности. Со своей стороны мы попытаемся, говоря о ресурсах, указывать, в электронную подписку каких организаций он входит.

\section{Типы баз данных периодики}

На данный момент в мире существуют десятки провайдеров, «агрегаторов», накопителей и распространителей информационных баз данных периодики с онлайн- или ондискдоступом. Каждая компания на рынке таких систем ставит свои задачи, имеет свою «целевую аудиторию», по-своему строит отношения с издателями.

1. Реферативные базы данных. Во-первых, ряд баз данных формируется в результате сбора, анализа и индексирования только «первичной» библиографической информации по периодике: оглавлений журналов, иногда - аннотаций статей. Полных текстов в подобного рода системах нет. Для социологов среди таких «реферативных» ресурсов одной из наиболее ценных является база данных «Sociological Abstracts», созданная и поддерживаемая компанией «Cambridge Scientific Abstracts» (CSA). База аннотирует более 1700 периодических изданий по социологии и смежным наукам, включает также рефераты целых монографий или отдельных книжных глав, диссертаций, трудов конференций. Временной охват: оглавления — с 1963 г., аннотации — с 1974 г. Добавление новых записей осуществляется ежемесячно, в настоящий момент объем базы около 573000 записей. Подробную информацию о «Sociological Abstracts» можно найти по адресу: http://www.csa.com/csa/factsheets/socioabs.shtml.

Доступ к этому ресурсу (собственно данным) организован через системы различных производителей (вспомогательные интерфейсы, поисковые механизмы). Это, во-первых, сам CSA (его Internet Database Service: http://www.csa.com/csa/ids/ids-main.shtml), а кроме того SilverPlatter (http://www.silverplatter.com/catalog/soci.htm) и недавно купивший его Ovid Technologies (http://www.ovid.com/products/databases/ database info.cfm?dbID=82), Dialog (http://library.dialog.com/bluesheets/html/bl0037.html) и др. Можно выбирать как между различными «провайдерами» (соответственно, варьирующимися ценами и разным качеством интерфейса), так и между способами доступа: доступ возможен в онлайне 
(через Интернет) или на компакт-дисках (обновления будут приходить по почте с периодичностью 2-3 месяца). Насколько нам известно, в данный момент подписки на Sociological Abstracts нет ни у одной российской организации. В 1996-1997 гг. базу выписывала на CD-ROM (тогда она называлась Sociofile) МВШСЭН. Компакт-диски за этот период можно найти в библиотеке вуза:

cм. http://www.msses.ru/prev/library/cd.html\#cd5. В текущем году подписку на онлайндоступ к Sociological Abstracts планирует осуществить библиотека ГУ-ВШЭ.

2. Электронные подписные агентства. Другие системы организуют онлайн-доступ к полным текстам изданий, но исключительно к тем, которые библиотека организации выписывает в печатном виде. И вполне логично, что при этом доступ к электронным версиям может предоставляться даже бесплатно. Впрочем, даже тут все зависит от политики издательства: наряду с изданиями, дающими подписчикам печатной версии бесплатную полнотекстовую электронную версию, существуют журналы, предоставляющие свободно только аннотации статей (а полные тексты - за дополнительную, для подписчиков, как правило, небольшую, плату) или даже только их оглавления. До сих пор есть также издания, не имеющие электронной версии, - чаще всего намеренно. Из провайдеров, специализирующихся на доступе к электронным версиям выписываемых «в бумаге» журналов, можно назвать компании Swets\&Zeitlinger (продукт SwetsNetNavigator: www.swetsnetnavigator.nl), EBSCO (EBSCO Online:_www.ebsco.com/online), Ingenta (www.ingenta.com), Catchword (www.catchword.com). В связи с тем, что данные системы дают приоритетный доступ только к изданиям, выписываемым библиотекой в бумажном виде, объем их контента напрямую зависит от количества наименований зарубежной периодики в библиотечной подписке. В условиях академических российских организаций это число редко превышает сотню (причем из них лишь часть предоставят бесплатный электронный вариант), потому доступ к таким ресурсам, как правило, малоэффективен. Отметим, кроме того, что если ученый подпишется на бумажную версию журнала самостоятельно, у него также будет возможность получить доступ к электронной версии через данные системы.

Нередко в качестве дополнения к сервисам, описанным в предыдущем абзаце, имеется возможность для не-подписчиков получить полные тексты публикаций на основе pay-perview, за отдельную плату для каждой статьи. Цены при этом несколько варьируются от ресурса к ресурсу (также, конечно, от журнала к журналу и от публикации к публикации), а статьи доставляются различными путями: по электронной почте, непосредственно в Интернет-браузер или даже по факсу.

3. Агрегаторы. Наиболее интересными и выгодными по соотношению «цена/объем» на данный момент являются ресурсы, которые принято называть «агрегаторами» периодики. Это системы, дающие доступ сразу ко множеству (иногда нескольким тысячам) научных зарубежных журналов многих издательств, как правило, сразу по нескольким дисциплинам. Причем выписывает ли библиотека издания в печатном виде, никак не влияет на ее доступ к электронному журналу. Фиксированная абонентская плата вносится за определенный срок (чаще всего за год), в течение которого университет или исследовательский центр неограниченно использует ресурс.

a) Aрхивы периодики. Описанные библиотечные системы также можно условно разделить на два типа: одни из них собирают только архив периодики, предоставляя доступ к журналам, вышедшим три года назад и ранее; другие, наоборот, фокусируются на текущих выпусках журналов. Один из крупнейших проектов первого типа - JSTOR (http://www.jstor.org). База данных включает в себя ограниченное количество журналов, однако принципы их подбора настолько профессиональны, что ресурс может сравниться по качеству контента со всеми агрегаторами, включившими в себя тысячи наименований. Все издания представлены в полнотекстовом формате (одновременно jpg-изображения и pdf-файлы). Журналы имеются, как правило, с первого их выпуска (иногда это XIX-й век!) 
до 1996-1998 гг.: свежих номеров в JSTOR нет (изредка издательство соглашается помещать свои журналы двухлетней давности, 2000 г.). Каждый год в базу включается очередной массив номеров трех-пятилетней давности. Весь массив журналов разбит на так называемые «коллекции», подборки журналов по одной или нескольким темам. В настоящий момент наиболее используемой коллекцией является «Arts \& Sciences I Collection». Стоит перечислить, какие социологические издания в нее включены:

American Journal of Sociology Vols. 1-105, 1895-2000.

American Sociological Review Vols. 1-61, 1936-1996.

Annual Review of Sociology Vols. 1-22, 1975-1996.

Contemporary Sociology Vols. 1-25, 1972-1996.

Journal of Black Studies Vols. 1-29 (Issue 2), 1970-1998.

Journal of Health and Social Behavior Vols. 8-37, 1967-1996 (прежнее название: Journal of Health and Human Behavior Vols. 1-7, 1960-1966).

Public Opinion Quarterly Vols. 1-63, 1937-1999.

Social Psychology Quarterly Vols. 42-59, 1979-1996 (прежние названия: Social Psychology Vol. 41, 1978 и Sociometry Vols. 1-40, 1937-1977).

Sociology of Education Vols. 37-69, 1963-1996 (прежнее название: Journal of Educational Sociology Vols. 1-36, 1927-May 1963).

K Arts \& Sciences I Collection имеют доступ уже целых 15 учебных и исследовательских заведений России: МГУ, ГУ-ВШЭ, МВШСЭН, ЕЕRС, РЭШ, Европейский Университет в Санкт-Петербурге, Казанский, Красноярский, Новосибирский, Ростовский, Саратовский, Нижегородский, Уральский и Дальневосточный государственные университеты, Таганрогский государственный радиотехнический университет.

б) Актуальная периодика. Если же говорить об электронных ресурсах актуальной периодики, то таких проектов значительное количество, однако из них мы выберем для подробного рассмотрения только три:

\section{Продукт:}

EBSCOhost

ProQuest

InfoTrac
Производитель:

EBSCO Publishing

ProQuest Company

Gale Group companies
URL:

http://www.epnet.com

http://www.proquest.com

http://www.galegroup.com

Наряду с масштабностью этих баз данных и значительным объемом информации по социальным наукам, содержащимся в них, мы принимали во внимание тот факт, что перечисленные агрегаторы получают или активно стремятся получить широкое распространение в России. По данной причине именно эти базы мы рассмотрим подробно во второй части нашего обзора, когда будем говорить о представлении в электронных ресурсах конкретных журналов, актуальных для экономсоциологов. Пока дадим несколько пояснений о структуре агрегаторов и доступе к ним.

Каждая система (EBSCOhost, ProQuest, InfoTrac) может дать доступ к нескольким, порой около 20-30, базам различной тематики (некоторые из них могут быть и политематическими) - при условии оформления подписки на них. Такие базы данных, являющиеся подмножествами всего информационного массива, к которому каждый агрегатор может предоставить доступ, названы «частными базами данных». В связи с тем, что подписываться на все частные базы данных нецелесообразно, да и едва ли какая-либо академическая библиотека может себе это позволить, мы ограничимся обзором лишь 
некоторых из них, фокусирующихся на социологической или экономической тематике. Соответствующий набор «частных» баз приведен ниже в табл. 1.

Таблица 1 «Частные» базы данных, выбранные для анализа

Academic Search Premier

EBSCOhost Business Source Premier

MasterFILE Premier

Social Sciences PlusText ABI/INFORM Global

ProQuest Academic Research Library

ProQuest Education Complete

InfoTrac InfoTrac OneFile

Выбор баз данных сделан таким образом, что можно утверждать: если журнала по социальной или экономической тематике нет в указанных продуктах, то с очень высокой вероятностью его нет и во всех «частных» базах данных, предоставляемых данной системой. Т.е. если издание по экономике отсутствует, например, в «Academic Search Premier», «Business Source Premier» и «MasterFILE Premier», то его нет ни в одной базе данных, к которым можно получить доступ через EBSCOhost. Помимо того, что перечисленные базы данных составляют основной общественно-научный контент исследуемых ресурсов, именно эти продукты получают распространение в российских университетских и публичных библиотеках.

Базы данных серии «Premier» заявляются компанией EBSCO Publishing как наиболее представительные собрания периодических изданий, и именно к перечисленным базам дается доступ в рамках широко известной программы Electronic Information for Libraries (EIFL Direct) и Электронно-Информационного консорциума (ЭИКОН), число российских библиотек - участников которых составляет в настоящий момент около 140 (в частности, библиотеки ГУ-ВШЭ, МВШСЭН, МГИМО, СПбГУ, НГУ, а также РГБ, ВГБИЛ и др.; полный список доступен по адресу: http://www.eikon.osi.ru/php/ participants find.php).

Базы данных, выбранные нами для исследования контента ProQuest, входят в подписку консорциума шести московских и одного новосибирского университетов: в настоящий момент доступ имеют МВШСЭН, ГУ-ВШЭ, РГГУ, РАГС, НГУ, РЭШ, Институт социологии РАН. Консорциум открыт для приема новых членов и постоянно растет (вероятно, в ближайшем будущем доступ приобретут МГИМО и библиотека Администрации президента).

Наконец, собранные воедино практически все ресурсы InfoTrac образовали базу данных «InfoTrac OneFile» (это нечастый случай создания «интегральной» базы внутри одного агрегатора; такой ресурс уже некорректно называть «частной» базой данных), которая, по словам вице-президента Gale Group Джона Барнса, является «идеальным продуктом для больших библиотек и консорциумов». В настоящий момент, насколько нам известно, в России нет организаций, использующих базы данных InfoTrac, однако за последний год разным организациям (ГУ-ВШЭ, МВШСЭН, недавно - РГБ) давался кратковременный тестовый доступ к ресурсу, и не исключено, что вскоре какая-либо из них приобретет годичную подписку.

Все приведенные в таблице базы данных имеют сходную структуру: в них включаются как аннотации статей, так и для некоторых из журналов - полные тексты. Обычно доля полнотекстовых журналов составляет около 50\%. Ряд издателей позволяют производителям электронных библиотечных ресурсов помещать полный текст своих 
журналов только по истечении некоторого времени после выхода печатной версии - это так называемое эмбарго. Чаще всего встречаются 6-, 12-, 24- и 36-месячные эмбарго. Например, 24-месячное эмбарго означает, что в мае 2002 г. в ресурсе можно найти журнал за май 2000 г. (за II квартал 2000 г. для ежеквартальников) или более старые выпуски.

Итак, каждый журнал в базах данных агрегаторов может быть представлен либо в виде только аннотаций (мы будем обозначать такое представление $\mathrm{Ab}$ ), либо в виде полных текстов - без задержки (FT) или с ней (в таком случае мы будем указывать величину эмбарго в месяцах). Наконец, встречается также ситуация, когда некоторое время назад полный текст издания прекратил поступать в ресурс, однако имеющиеся прежние полнотекстовые выпуски сохранены. В этом случае мы ставим после цифры, равной количеству месяцев с момента отказа от журнала, значок «х»- например, «12 х».

\section{Представление ведущих зарубежных журналов по экономической социологии в электронных базах данных}

Чтобы получить информацию обо всех наименованиях изданий, включенных в тот или иной ресурс, можно воспользоваться составленными производителем «списками журналов» [title lists], в которых отражены временные промежутки представления изданий (дата первого включенного номера, дата последнего присутствующего в базе номера), виды их представления (FT или $\mathrm{Ab}$ ), информация о существующем эмбарго. Списки доступны в сети Интернет:

EBSCOhost: $\quad$ http://www.epnet.com/titlelists.asp

ProQuest: $\quad$ http://www.proquest.com/division/tl-menu.shtml

InfoTrac: $\quad$ http://www.galegroup.com/tlist/sb5101.html

Мы, однако, ограничимся изучением представленности в базах данных только тех зарубежных журналов, которые являются важнейшими для российских специалистов по экономической социологии. Ниже мы приводим список этих изданий с указанием их «импакт-фактора» - индекса цитируемости, вычисляемого ежегодно филадельфийским Институтом научной информации [Institute for Scientific Information, ISI] ${ }^{2}$.

Таблица 2. Журналы, актуальные для экономсоциологов России. Индекс цитируемости

\begin{tabular}{|l|l|}
\hline \multicolumn{1}{|c|}{ Название } & Индекс цитируемости \\
\hline Journal of Economic Literature & 6,68 \\
\hline Administrative Science Quarterly & 3,33 \\
\hline American Sociological Review & 3,26 \\
\hline American Journal of Sociology & 2,83 \\
\hline Annual Review of Sociology & 2,81 \\
\hline Academy of Management Journal & 2,38 \\
\hline Journal of Political Economy & 2,32 \\
\hline Economy and Society & $1,98(1997)$ \\
\hline American Economic Review & 1,78 \\
\hline Sociological Review & 1,07 \\
\hline Work and Occupations & $0,84(1999)$ \\
\hline Social Networks & $0,83(1999)$ \\
\hline
\end{tabular}

\footnotetext{
${ }^{2}$ Список журналов составлен В.В. Радаевым.
} 


\begin{tabular}{|l|l|}
\hline Work Employment and Society & $0,64(1999)$ \\
\hline British Journal of Sociology & $0,59(1999)$ \\
\hline Acta Sociologica & $0,52(1999)$ \\
\hline International Sociology & $0,35(1999)$ \\
\hline Kyklos & 0,31 \\
\hline American Journal of Economics and Sociology & 0,17 \\
\hline
\end{tabular}

Вкратце опишем процедуру вычисления импакт-факторов ISI. Индекс цитируемости (импакт-фактор) отражает количество цитат, ссылок на «среднюю статью» в некотором периодическом издании и считается на определенный год. Если это год N, то импактфактор равен числу всех цитирований статей данного журнала, вышедших в годах N-1 и $\mathrm{N}-2$, в статьях всех журналов, вышедших в году $\mathrm{N}$, деленному на общее количество статей, опубликованных в данном журнале за годы $\mathrm{N}$ и $\mathrm{N}-1$. Такой показатель считается и изменяется ежегодно ${ }^{3}$.

Отметим также, что по классификации ISI два из приведенных журналов относятся одновременно к экономике и социологии («Work Employment and Society» и «American Journal of Economics and Sociology»), три — только к экономике («Journal of Economic Literature», «Journal of Political Economy», «Economy and Society»), два - к бизнесу («Administrative Science Quarterly» и «Academy of Management Journal»). Остальные помещены в рубрикаторе только в раздел «Социология».

Сначала рассмотрим, как представлены издания в архивной базе данных JSTOR (часть журналов уже встречалась ранее при описании социологического контента JSTOR).

Таблица 3. База данных JSTOR

\begin{tabular}{|l|c|}
\hline \multicolumn{1}{|c|}{ Название журнала } & $\begin{array}{c}\text { Представленность в } \\
\text { JSTOR }\end{array}$ \\
\hline Journal of Economic Literature & $1963-1998$ \\
\hline Administrative Science Quarterly & $1956-1998(\mathrm{~B})$ \\
\hline American Sociological Review & $1936-1996$ \\
\hline American Journal of Sociology & $1895-2000$ \\
\hline Annual Review of Sociology & $1975-1996$ \\
\hline Academy of Management Journal & $1958-1996(\mathrm{~B})$ \\
\hline Journal of Political Economy & $1992-2000$ \\
\hline Economy and Society & $1986-1998$ \\
\hline American Economic Review & \\
\hline Sociological Review & \\
\hline Work and Occupations & \\
\hline Social Networks & \\
\hline Work Employment and Society & \\
\hline British Journal of Sociology & \\
\hline Acta Sociologica & \\
\hline
\end{tabular}

${ }^{3}$ Для ряда журналов импакт-факторы за 2000 г. остались нам недоступны. В таких случаях в скобках приводится год, на который посчитан приведенный индекс цитируемости. Подробнее о процедуре подсчета импакт-факторов и их правильном использовании см.: Garfield E. The Impact Factor, Current Contents (1994). No. 25. P. 3-7 // http://www.isinet.com/isi/hot/essays/ journalcitationreports/7.html; Idem. Using the impact factor, Current Contents (1994). No. 29. P. 3-5//

http://www.isinet.com/isi/hot/essays/journalcitationreports/8.html. 


\begin{tabular}{|l|l|}
\hline International Sociology & \\
\hline Kyklos & \\
\hline American Journal of Economics and Sociology & \\
\hline
\end{tabular}

Как отмечалось, все издания, включенные в JSTOR, представлены в полнотекстовом виде. Два журнала, помеченные скобкой (В), входят в «Business Collection», недавно добавленную в JSTOR новую подборку журналов (насколько нам известно, в текущий момент подписчиков в России нет). Отметим, кстати, что JSTOR действительно покрывает все издания с высоким индексом цитируемости - наглядно проявляется принцип включения наиболее авторитетных журналов.

Наконец, приведем таблицу представленности в электронных ресурсах актуальных выпусков перечисленных изданий, ключевых для экономсоциологов.

Таблица 4. Издания для экономсоциологов в электронных ресурсах

\begin{tabular}{|c|c|c|c|}
\hline Название журнала & EBSCOhost & ProQuest & InfoTrac \\
\hline $\begin{array}{l}\text { Journal of Economic } \\
\text { Literature }\end{array}$ & $\begin{array}{c}\mathbf{3 6} \\
(1969- \\
\text { Mar 1999) } \\
\end{array}$ & $\begin{array}{c}\mathbf{3 6} \\
(1991-\operatorname{Mar} 1999)\end{array}$ & $\mathbf{A b}$ \\
\hline $\begin{array}{l}\text { Administrative } \\
\text { Science Quarterly }\end{array}$ & $\begin{array}{c}\text { FT } \\
(1965- \\
\text { Dec 2001) } \\
\end{array}$ & $\begin{array}{c}9 \mathbf{x} \\
(1987-\text { Sep 2001) }\end{array}$ & $\begin{array}{c}\text { FT } \\
(1989-\text { Dec 2001) }\end{array}$ \\
\hline $\begin{array}{l}\text { American Sociological } \\
\text { Review }\end{array}$ & $\mathbf{A b}$ & $\begin{array}{c}\text { FT } \\
(1988-\text { Feb2002) }\end{array}$ & $\mathbf{A b}$ \\
\hline $\begin{array}{l}\text { American Journal of } \\
\text { Sociology }\end{array}$ & $\begin{array}{c}9 \\
\text { (Jul 1990- } \\
\text { Jul 2001) } \\
\end{array}$ & $\frac{\mathbf{6}}{(1988-\operatorname{Sep} 2001)^{*}}$ & $\begin{array}{c}\text { FT } \\
\text { (Nov 1992- } \\
\text { Sep 2001) } \\
\end{array}$ \\
\hline $\begin{array}{l}\text { Annual Review of } \\
\text { Sociology }\end{array}$ & $\begin{array}{c}\mathbf{F T} \\
(1996-1997, \\
2000-2001)\end{array}$ & $\begin{array}{c}12 \\
(1995-2000)\end{array}$ & $\begin{array}{c}\text { FT } \\
(1993-2001)\end{array}$ \\
\hline $\begin{array}{l}\text { Academy of } \\
\text { Management Journal }\end{array}$ & $\begin{array}{c}\text { FT } \\
(1958- \\
\text { Feb 2002) }\end{array}$ & $\stackrel{6}{\mathbf{6} \mathbf{x}}$ & $\begin{array}{c}\mathbf{1 8} \mathbf{x} \\
(1993-\text { Nov 2000) }\end{array}$ \\
\hline $\begin{array}{l}\text { Journal of Political } \\
\text { Economy }\end{array}$ & $\begin{array}{c}\text { FT } \\
(1965- \\
\text { Apr 2002) } \\
\end{array}$ & $\begin{array}{c}\text { FT } \\
(1987-\text { Feb 2002) }\end{array}$ & $\begin{array}{c}\text { FT } \\
\text { (Jun 1992- } \\
\text { Apr 2002) } \\
\end{array}$ \\
\hline Economy and Society & $\begin{array}{c}12 \\
(2000- \\
\text { Feb 2001) } \\
\end{array}$ & $\mathbf{A b}$ & $\mathbf{A b}$ \\
\hline $\begin{array}{l}\text { American Economic } \\
\text { Review }\end{array}$ & $\begin{array}{c}\mathbf{3 6} \\
(1965- \\
\text { Mar 1999) } \\
\end{array}$ & $\begin{array}{c}\mathbf{3 6} \\
(1987- \\
\text { Mar 1999) } \\
\end{array}$ & $\mathbf{A b}$ \\
\hline Sociological Review & $\begin{array}{c}12 \\
(1975- \\
\text { Feb 2001) } \\
\end{array}$ & $\underset{(\text { May 1997-Nov 2001)** }}{\text { FT }}$ & $\mathbf{A b}$ \\
\hline
\end{tabular}




\begin{tabular}{|c|c|c|c|}
\hline Work and Occupations & $\begin{array}{c}\mathbf{1 2} \\
(1990- \\
\text { Feb 2001) } \\
\end{array}$ & $\frac{12}{(1988-F e b ~ 2001)}$ & $\mathbf{A b}$ \\
\hline \multicolumn{4}{|l|}{ Social Networks } \\
\hline \multicolumn{4}{|l|}{$\begin{array}{l}\text { Work Employment } \\
\text { and Society }\end{array}$} \\
\hline $\begin{array}{l}\text { British Journal of } \\
\text { Sociology }\end{array}$ & $\begin{array}{c}\mathbf{1 2} \\
(1975-\mathrm{Mar} \\
2001) \\
\end{array}$ & $\mathbf{A b}$ & \\
\hline Acta Sociologica & $\begin{array}{c}\mathbf{2 4} \\
(1975-A p r \\
2000) \\
\end{array}$ & & $\mathbf{A b}$ \\
\hline $\begin{array}{l}\text { International } \\
\text { Sociology }\end{array}$ & $\begin{array}{c}\mathbf{1 2} \\
(1999-\mathrm{Mar} \\
2001)\end{array}$ & & \\
\hline Kyklos & $\begin{array}{c}\mathbf{1 2} \\
(1974-J a n \text { 2001) }\end{array}$ & $\begin{array}{c}\text { FT } \\
(1996-\operatorname{Jan} 2002)^{* *}\end{array}$ & $\mathbf{A b}$ \\
\hline $\begin{array}{l}\text { American Journal of } \\
\text { Economics and } \\
\text { Sociology }\end{array}$ & $\begin{array}{c}\mathbf{1 2} \\
(1965-\mathrm{Apr} \\
2001)\end{array}$ & $\begin{array}{c}\text { FT } \\
(\text { Oct 1995-Jan 2002)** }\end{array}$ & $\begin{array}{c}\text { FT } \\
\text { (Oct 1993-Jan } \\
\text { 2002) }\end{array}$ \\
\hline
\end{tabular}

FT — полный текст без задержки; 6, 12, etc. — величина «эмбарго»; 6 x, 12 x, etc. полный текст прекратил поступать в ресурс; $\mathrm{Ab}$ - только аннотации.

* Не включены рецензии на книги.

** Пересылка по факсу.

Как уже говорилось, в базы данных агрегаторов издания включаются в разных форматах. Пользуясь условными обозначениями, введенными выше, мы отразили в таблице типы представления всех анализируемых нами изданий. Кроме того, для журналов, имеющих полный текст (с эмбарго или без него), указаны даты первого и последнего представленного в ресурсе полнотекстового выпуска. Отмечены также специфические для ProQuest типы представления: в случае одного журнала не включаются публикуемые в нем рецензии на книги («American Journal of Sociology»), еще три издания не выводят свои полные тексты на экран компьютера пользователя, но позволяют пользователю заказать статьи по факсу (бесплатно).

Краткий анализ показывает, что два журнала из восемнадцати вообще никак не отражены в исследуемых ресурсах («Social Networks» и «Work Employment and Society»). Полные тексты всех остальных имеются в какой-либо из систем, причем все кроме одного содержатся в EBSCO (чаще - с некоторым эмбарго). Таким образом, в EBSCO имеются 15 полных текстов, в ProQuest - 10, в InfoTrac - 5 (издания, поступление которых в ресурс прекратилось, мы не учитываем). Что касается полных текстов без задержки (эмбарго), то имеем в EBSCO 4 таких журнала, в ProQuest - 5, в InfoTrac - 5.

Вывод может быть таков: электронные базы данных зарубежной периодики предоставляют доступ к большинству актуальных для специалистов по экономической социологии изданий, однако ко многим из них - с годовой и более задержкой. По этой причине использование электронных ресурсов должно являться необходимым условием 
для полноценной информационной поддержки исследовательской деятельности, но не должно - по крайней мере в настоящий момент - полностью заменять собой подписку на «традиционные», печатные версии журналов. 


\title{
Новые книги
}

$\boldsymbol{V R}$ Предлагаем вашему вниманию перевод рецензии на новую книгу П. Асперса (Швеция) «Рынки в сфере моды: феноменологический подход» (2001). Асперс способный молодой исследователь, один из тех, кто уже третий год координирует работу Европейской исследовательской сети «Экономическая социология».

Aspers, Patrik. Markets in Fashion, A Phenomenological Approach. Stockholm: City University Press, 2001.

Асперс П. Рынки в сфере моды: феноменологический подход.

\author{
Йорг Рёссель ${ }^{1}$ \\ Лейпцигский университет \\ Email: roessel@,rz.uni-leipzig.de
}

Перевод М.С. Добряковой

Научное редактирование - В.В. Радаев

Рынки являются одной из тех областей исследования, в которых экономическая социология предоставляет более продвинутое объяснение хозяйственной реальности по сравнению с объяснением с позиций основного направления неоклассической экономической теории. Особенно это верно в отношении рынков, на которых ведущую роль играют эстетические ценности: например, на рынках театра и кино, живописи, музыки или рынках фотографии моды - которые и стали предметом исследования Патрика Асперса «Рынки в сфере моды». Исходной теоретической точкой книги стал обзор социологических теорий рынка, с одной стороны, и феноменологической социологии, с другой. В частности, центральное место в рассуждениях Асперса занимает идея Хэррисона Уайта [Harrison White] о том, что компании обладают определенной идентичностью и контролируют свои параметры относительно аналогичных параметров других производителей на данном рынке. В теории Уайта ниша, занимаемая фирмой, или ее идентичность, есть особое сочетание меняющихся объема, цены и качества [Aspers 2001: 37]. Это особенно заметно на художественных рынках, где непросто объективно определить качество продуктов, и акторы (особенно потребители) сталкиваются с ситуацией неопределенности, а статусная иерархия [status order], уменьшающая степень этой неопределенности, формируется в ходе взаимодействия между производителями и потребителями [Aspers 2001: 44]. Говоря о киноиндустрии Голливуда, Роберт Фолкнер [Robert Faulkner] подчеркивал, что репутация и статус различных акторов складываются в процессе рыночного взаимодействия. Следовательно, успешный кинопроект обеспечит всех участников хорошей репутацией и более высоким, чем прежде, статусом на рынке. В отличие от большей части подобных социологических теорий рынка исследование Асперса следует феноменологическому подходу. В то время как большинство теоретиков, пишет Асперс, наблюдают реальность и приписывают акторам содержательные смыслы [mental content], феноменологическая социология утверждает, что объяснить социальные явления невозможно без обращения к анализу самой структуры смыслов индивидов [Aspers 2001: 49-50]. И одно из многих достоинств книги Асперса состоит в наличии

1 Переведено по: Jörg Rössel, in: Economic Sociology. European Electronic Newsletter (February 2002). Vol. 3, No. 2. http://www.siswo.uva.nl/ES 
приложения, в котором содержится очень хорошо структурированное введение в феноменологическую социологию.

Такова теоретическая база исследования рынков фотографии моды [fashion photography] в Швеции, которое Асперс выполнил на основе ряда интервью с различными группами акторов в данной области и количественного обследования шведских фотографов. Начав с систематичного описания различных участников рынка фотографии моды (ассистентов фотографов и их агентов, самих фотографов, стилистов, моделей и т.д.), в 3-й главе он переходит к анализу ролевой и смысловой структуры действий фотографов как производителей на рынке фотографии моды. Он показывает, что фотограф ориентирован прежде всего на других фотографов [Aspers 2001: 110], однако для формирования своей идентичности в качестве фотографа ему необходимо взаимодействие с клиентами главным образом, модными журналами, образующими стабильную статусную иерархию [Aspers 2001: 116]. Эти журналы дают шанс войти на рынок фотографии моды, предложить свой собственный особый стиль и в целом выполняют функцию доски объявлений для фотографов и их клиентов. В отличие от фотографирования для журналов, работа для рекламного агентства и особенно для каталогов, рассылаемых по почте, оставляет гораздо меньше места для художественной свободы [Aspers 2001: 137]. Модные журналы платят за фотографии примерно одинаково, в то время как дневные расценки на рекламную фотографию существенно различаются. И только на этом рекламном рынке модной фотографии можно превратить статус в деньги [Aspers 2001: 141-142].

В своем исследовании Асперс разграничивает две категории фотографов моды: фотографов высокой моды и фотографов «обычной моды» [high fashion and low fashion]. Первая категория заботится о своей идентичности, статусе и стиле, отклоняя предложения о работе со стороны низкостатусных модных журналов и почтовых каталогов - словом, руководствуется своей художественной логикой. В то время как фотографы «обычной моды» редко отказываются от работы и воспринимают себя, скорее, как ремесленников, готовых угодить своим клиентам [Aspers 2001: 145-153]. О том, что у фотографов высокой моды значительно более высокий статус, свидетельствует и тот факт, что фотографы обычной моды много о них знают и стараются на них походить - обратный же интерес скорее отсутствует. В последующих главах Асперс рассматривает смысловую структуру действия потребителей (главным образом, редакторов модных журналов и художественных директоров рекламных агентств) по отношению к рынку фотографии моды, демонстрируя существование двух рынков фотографии моды. С одной стороны, есть рынок журнальной фотографии моды, функционирующий в соответствии с логикой искусства, творческой деятельности, ценности уникального. С другой стороны, есть рынок рекламы, живущий по экономическим законам, и здесь у фотографов значительно меньше художественной свободы, зато можно заработать больше денег. Самую высокую оплату за работу в рекламном бизнесе получают фотографы, которые публикуются в высокостатусных журналах моды [Aspers 2001: 213]. И с этих позиций цены на рекламную фотографию можно рассматривать как эпифеномен статусной иерархии [status distribution] в области журнальной фотографии моды [Aspers 2001: 208].

В заключение хотелось бы отметить, что исследование Асперса - очень хороший пример социологической работы. Оно знакомит читателя со смысловой структурой действия акторов на рынке фотографии моды и, тем самым, позволяет лучше объяснить и глубже понять этот вид рынка. Делая акцент на субъективных смыслах, это исследование серьезно противостоит более ранним исследованиям художественных рынков, построенным на структуралистских объяснениях с опорой на количественные данные. Поэтому данное исследование имеет все основания стать важной отправной точкой, в том числе и для количественного анализа художественных рынков. 
$\boldsymbol{V} \boldsymbol{R}$ Мы обращаем внимание на книгу, посвященную одному из наиболее загадочных явлений российского рынка труда 1990-х гг. Чем объяснялись хронические неплатежи и задержки заработной платы, почему менеджеры и работники мирились с подобной ситуацией - об этом рассуждают лучшие отечественные и зарубежные авторы по проблемам российской занятости. В нашем журнале уже затрагивалась данная тема ${ }^{1}$. Учитывая звездный состав авторов и загадочность проблемы, настоятельно советуем ее прочитать.

Зарплата и расплата: проблемы задолженности по оплате труда / Под ред. Т.М. Малевой. Московский Центр Карнеги. М.: Гендальф, 2001.

Малева Татьяна Михайловна

к.э.н., Независимый институт социальной политики

Email: maleva@socialpolicy.ru

\section{Содержание}

Татьяна Малева. Долг перед задолженностью. Вместо введения и заключения.

Владимир Гимпельсон. Политическая экономия российского рынка труда.

Ростислав Капелюшников. Задержки заработной платы: микроэкономический подход.

Джон С. Эрл, Клара Сабирьянова. Равновесные задержки заработной платы: теоретический и эмпирический анализ институциональной ловушки в России.

Хармут Леманн, Джонатан Уадсворт, Алессандро Аквисти. Разложение и наказание: трудовая незащищенность и задолженности по заработной плате в Российской Федерации.

Саймон Кларк. Профсоюзы и неплатежи заработной платы в России.

Проблема внутреннего долга касается самого многочисленного отряда кредиторов российской экономики. Речь идет о проблеме невыплат заработной платы миллионам работников, занятым на российских предприятиях. Именно этот феномен - масштабное распространение невыплат заработной платы - в полном объеме проявил уникальность российского рынка труда и качественное его отличие от рынков труда других стран, переживающих стадию трансформации. Он является продолжением ряда «нестандартных» реакций рынка труда на радикальное изменение экономических условий-«придерживание» излишней рабочей силы на предприятиях, практика вынужденных неоплачиваемых отпусков, широкое распространение неполной занятости. Все они, включая невыплаты заработной платы, - множественные проявления, имеющие общий корень, - это попытка адаптироваться к вызовам рынка без радикальных структурных изменений.

${ }^{1}$ См.: Радаев B.В. Работающие бедные: велик ли запас прочности (2000. Том 1, № 1); Капелюшников Р. И. Российский рынок труда: адаптация без реструктуризации (2000. Том 2, № 2). 
В настоящей публикации представлены статьи известных российских и зарубежных исследователей, в которых предпринимается попытка добраться до понимания корней неблагополучия, сложившегося в сфере оплаты труда и вызвавшего феномен задержек заработной платы.

Открывает сборник статья Владимира Гимпельсона, в которой проблема задолженности рассматривается в общем контексте макропроцессов на российском рынке труда и уникального набора нестандартных форм его адаптации к новым рыночным реалиям, привнесенным российскими реформами начала 1990-х гг. Действительно, вне спирали «занятость - безработица - инфляция - номинальная и реальная заработная плата» понять причины масштабности и устойчивости невыплат невозможно. Автор не ограничивается исследованиями лишь экономических взаимосвязей. По его мнению, задолженность по оплате труда формировалась под влиянием целого ряда политических и институциональных факторов и в значительной мере являлась продуктом так называемого политико-делового цикла (ПДЦ), в котором концентрировались все политэкономические особенности трансформационной экономики, как то: противоречивые интересы экономических субъектов, разнонаправленные приоритеты различных политических сил и институтов, непрозрачность бюджетного процесса и финансовых потоков и т.д. Ситуация на рынке труда, в том числе с позиций хронических невыплат заработной платы, рельефный пример теории «выхода и голоса», предложенной А. Хиршманом и развитой В. Гимпельсоном применительно к современной России.

Ростислав Капелюшников представляет результаты исследования проблемы невыплат на микроэкономическом уровне. Автора не удовлетворяют традиционные ссылки на общий кризис неплатежей, поразивший российскую переходную экономику, как на базовую причину массовой практики невыплат. Фокус его исследования - попытка ответить на вопрос, насколько возникновение задолженности обусловлено объективными показателями функционирования предприятий и каковы мотивы и действия их администраций в отношении своевременной выплаты вознаграждения за труд. На основе опросной статистики автор приходит к неутешительному выводу о том, что задолженность по оплате труда - не недоразумение и не технический сбой, а инструмент адаптации, виртуозно освоенный всеми участниками российского рынка труда, начиная от государства и кончая менеджерами предприятий. Российские работники, конечно, без энтузиазма, но также смирились с подобной дискриминацией. Измерения, проведенные Р. Капелюшниковым в ходе социологического обследования, показывают, что напряжение в обществе в связи с невыплатами даже не достигло критического значения, после которого вероятен социальный взрыв. Феномен долготерпения российского неоплаченного (недооплаченного) работника - факт, неизменно вызывающий всеобщее удивление, - получил объяснение.

Джон Эрл и Клара Сабирьянова в своей статье обнаруживают и объясняют любопытный феномен - самораспространение задолженностей. Если на локальном рынке труда существует либо критическое число работодателей, либо один крупный работодатель (которым, без сомнения, является государство), практикующие невыплаты своим работникам, это служит сигналом и провокацией для остальных субъектов - они следуют их примеру, и, как результат, невыплаты стремительно распространяются на данном рынке. Авторы отвечают, пожалуй, на главный вопрос - почему задолженности воспроизводятся с такой поразительной устойчивостью. Из предложенной ими модели следует, что в российской экономике сложилось устойчивое равновесное состояние, предполагающее задержки или неполную выплату зарплаты. И пусть читателя, неискушенного в эконометрике, не смущает подробное описание инструментов математической модели. Заключения, следующие из модели, просты, понятны и полезны:

\footnotetext{
${ }^{2}$ Hirschman, Alfred. Exit, Voice and Loyalty. Cambridge: Cambridge University Press, 1970.
} 
издержки по выходу из этого состояния намного выше, нежели издержки по предотвращению невыплат.

Хармут Леманн, Джонатан Уадсворт, Алессандро Аквисти приходят к заключению, что географическое положение региона (независимо от его экономической структуры) является ключевым фактором, влияющим на уровень задолженностей по зарплате. Отсюда также следует непреложный политический вывод, который, очевидно, и был реализован на практике. Согласно русской традиции, бунт или революция обычно имеют шансы на успех в случае их осуществления в центре. Сместив же центр тяжести по невыплатам в провинции, федеральный центр сумел избежать социальных катаклизмов. Объясняя долготерпение российских работников, страдающих от хронических невыплат, и их привязанность к предприятию, не выполняющему своих денежных обязательств, авторы подчеркивают, что увольнение и последующее трудоустройство возможны лишь на рынках труда в крайне ограниченном числе регионов. На большинстве локальных рынков труда нет вакантных рабочих мест, что практически исключает движение рабочей силы.

В перечисленных работах обсуждаются мотивы и последствия поведения основных экономических субъектов рынка труда - государства (в лице федерального и региональных бюджетов), работодателей (менеджеров), работников (или домохозяйств, в состав которых они входят). Между тем на рынке труда действует еще один актор профессиональные союзы, компетенцией которых является защита интересов работников, в том числе, несомненно, и нарушение условий оплаты их труда. Роли профсоюзов в разрешении конфликта по поводу задолженности по оплате труда посвящена статья Саймона Кларка. Профсоюзы оказались бессильны в борьбе с этим злом по целому ряду причин - как внутри профсоюзного движения, так и внешних, имеющих экономический и институциональный характер. Внутренний раскол и пассивность самих профсоюзов, их соглашательская позиция в ходе политико-делового цикла (хотя С. Кларк и не использует этот термин), с одной стороны, неразвитость механизмов банкротства, неэффективная судебная практика, с другой, привели к тому, что в российской ситуации неоплаченный (недооплаченный) работник остается один на один со своим работодателем и в подавляющем большинстве случаев проигрывает в этом единоборстве.

Несмотря на разницу в подходах - макроуровень (В. Гимпельсон), микроэкономический уровень (Р. Капелюшников), уровень домохозяйства (Х. Леманн и др.), а также на различия в используемой методологии - от дескриптивной (С. Кларк) до эконометрической (Дж. Эрл, К. Сабирьянова) - представленные работы объединены единой нитью. Это - признание глубины кризиса на российском рынке труда, его нестандартной реакции на вызовы рынка, объяснение феномена задолженности действием не текущих конъюнктурных факторов, а институциональных, политических и экономических деформаций в современной России. Все авторы едины во мнении, что масштабные невыплаты заработной платы - не эпизодическое явление, которое якобы разрешится автоматически на волне экономического роста, а серьезное институциональное нарушение, последствия которого российская экономика будет на себе испытывать в течение долгого времени.

Как потенциально может разрешиться этот конфликт? Этот вопрос возникает в двух ракурсах - в отношении старых, уже накопленных долгов, и в отношении будущей государственной бюджетной и корпоративной политики по своевременной выплате заработной платы.

Как следует из анализа, погашение имеющейся задолженности либо невозможно, либо сопряжено с непропорционально большими финансовыми издержками, что, вероятнее всего, по умолчанию приведет к амнистии долгов работодателя перед работниками. По сути дела, несопротивляемость общества в отношении невыплат и означает своеобразное 
прощение, которое изредка нарушается обещаниями официальных властей покончить с порочной практикой. Похоже, работодатели (включая бюджеты всех уровней) выиграют этот раунд. Между тем, в долгосрочном отношении это - Пиррова победа. В конечном итоге, выигравших нет, поскольку в действительности терпит фиаско вся система экономических отношений с еe политическими, юридическими и общественными институтами. Результатом эпопеи с задержками являются сохранение несбалансированности рынка труда, занятости и безработицы, воспроизводство порочной политики оплаты и ее несоразмерности реальной цене труда, неадекватность института профессиональных союзов и судебной системы вызовам рыночной экономики. Наконец, список социальных шоков и неудач реформ наряду с инфляционным обесценением дореформенных сбережений 1992 г., «черным вторником» 1994 г. или 17 августа 1998 г. можно будет продолжить внутренним дефолтом по заработной плате - дефолтом, растянутым во времени, но не менее драматичным по своим последствиям, поскольку в данном случае речь идет не о десятках или сотнях тысяч частных вкладчиков или обладателей сбережений, а о многих миллионах работников, которые, по существу, безвозмездно и безнадежно кредитуют российскую экономику.

В отношении же поведения работодателей в будущем рецепт, казалось бы, прост и уже упоминался - задолженность легче предотвратить, чем погасить. Однако в нынешних экономических, правовых и институциональных координатах, как поймет внимательный читатель, воспроизводство практики невыплат почти неизбежно. Без реструктуризации этих координат российский рынок труда обречен на эскалацию того острого конфликта, коим является задолженность по оплате труда вне зависимости от того, активную или пассивную, открытую или скрытую форму он принимает. 


\title{
Исследовательские проекты
}

$\boldsymbol{V} \boldsymbol{R}$ Мы знакомим вас с двумя очередными проектами Независимого института социальной политики.

\section{СОЦИАЛЬНО-ПРОСТРАНСТВЕННАЯ ДИФФЕРЕНЦИАЦИЯ НАСЕЛЕНИЯ САНКТ-ПЕТЕРБУРГА ${ }^{1}$}

\author{
Руководитель проекта: Н.P. Корнев, ст. научный сотрудник Социологического \\ института РАН \\ E-mail: nikorn@NK4541.spb.edu
}

\section{Участники проекта:}

Ю.П. Коровяковский, руководитель группы геоинформационных систем городского Вычислительного центра коллективного пользования «Жилищное хозяйство» (ВЦКП);

В.М. Ершов, заместитель директора ВЦКП;

А.А. Андронова, зав. отделом перспективных разработок ВЦКП;

Е.М. Порецкина, научный сотрудник ИС;

О.В. Матюхин, председатель совета директоров Агентства урбанистических исследований и консультаций.

Сроки реализации проекта: 1 марта 2001 г. - 28 февраля 2002 г.

Цель исследования: определение социальной стратификации населения в городском жилищном пространстве и структуры городской территории по различным жилищным показателям.

\section{Задачи исследования}

- Построение карт центральной части Петербурга на основе ряда показателей жилищ и домохозяйств, рассчитываемых по данным об их генеральных совокупностях в пределах изучаемых территорий.

- Определение жилищных характеристик городской элиты, ее распределения в городском пространстве для выявления жилищных индикаторов высокого социального статуса.

- Анализ структуры заселения многоквартирных домов в центре Петербурга, имеющих репутацию престижных и наиболее социально однородных, для выявления их жилищных индикаторов.

- Изучение процесса перераспределения населения в городском жилищном пространстве, обусловленного социально-экономическими изменениями, и сообществ жителей в престижных домах центра Петербурга.

1 Проект реализован в рамках программы «Социальная политика: реалии XXI века» Независимого института социальной политики при финансовой поддержке Фонда Форда (грант SP-01-1-14). 


\section{Методология исследования}

Для построения карт использованы базы данных ВЦКП, электронная карта Петербурга (1:10000) и ГИС MapInfo. Основным элементом всех карт является жилой квартал, для которого рассчитывались средние значения различных жилищных показателей. Расчет произведен по всему жилью и населению каждого квартала и/или для выделенных жилищных классов. Отсутствовали и не включены в анализ данные о ЖСК, товариществах и ведомственных домах, на которые приходится 3-7\% жилья в районах центра Петербурга. На карты наносили, как правило, 5 градаций параметра, вмещающих все множество его значений. Среди картированных показателей: доля в квартале коммунальных/отдельных квартир (домохозяйств, численности населения в них); доля частных/государственных квартир; жилая площадь на 1 человека; доля домохозяйств, получающих жилищную компенсацию на оплату жилья; средняя величина задолженности за жилье; и др.

Выборка 757 представителей городской элиты сформирована по данным справочников «Кто есть кто в Санкт-Петербурге» и «Кто есть кто в деловом Петербурге». Сферы бизнеса, государственного управления, науки и культуры/искусства представлены в выборке в отношении: 462:200:103:145 (часть персоналий включена в 2 группы). Изучение жилищных характеристик элиты и структуры заселения престижных домов выполнено с помощью базы данных «Oracle».

\section{Информационная база}

- Базы данных «Квартирная плата» четырех районов центра Петербурга (Центрального, Адмиралтейского, Петроградского, Василеостровского), содержащие сведения обо всем населении и жилье, используемые для расчета жилищно-коммунальных платежей. Общее число включенных в анализ объектов в этих районах - более 300 тыс. домохозяйств с 660 тыс. жителей в 196 тыс. квартир; 684 квартала с 5 тыс. жилых домов.

- Справочная база данных «Oracle» о жилье и населении города, предназначенная для органов управления.

- Более 50 интервью с жителями центра города, в домах с признаками высокого статуса (престижное место, высокая доля квартир в частной собственности и др.).

- Интервью активных участников конфликтов, связанных со строительством мансард в 10 домах, расположенных в престижных местах центра Петербурга; документы о развитии конфликта из архивов респондентов; публикации в газетах.

\section{Основные результаты}

Выделены 4 класса жилищ: коммунальные квартиры (низший класс); квартиры отдельные государственные; квартиры отдельные частные, с зарегистрированными (прописанными) в них жителями-собственниками; и «доходные» квартиры (высший класс) - отдельные частные, без прописанных в них граждан. Определены их численность и распределение в пространстве центра Петербурга. Доля доходных квартир в жилищном фонде и обеспеченность населения жилой площадью (кв. м/чел.) - показатели, наилучшим образом проявляющие ценность территории для проживания и пригодные для использования в качестве индикатора статуса квартала, дома. В пределах центра с их помощью выявлены зоны, где концентрируются наиболее и наименее состоятельные слои населения.

Вместе с тем, картографический анализ обнаруживает, что в настоящее время все жилищные классы в высокой степени совмещены в пространстве центра Петербурга. 
К такому же выводу приводит анализ жилищных показателей домохозяйств в 43 домах, имеющих репутацию социально однородных. В действительности многие из этих домов весьма гетерогенны по жилищному статусу их обитателей.

Распределение элиты в городском пространстве демонстрирует ценность центра, где концентрация ее жилищ в 7 раз выше, чем в остальной части города. Однако в районах центра элита рассредоточена по большей части их территории, за исключением самых непрестижных окраинных зон. Сведения о жилищных условиях элиты проявляют спектр ее потребления/владения в жилищной сфере, более высокого, чем у населения в целом.

По данным интервью, дома с населением смешанного социального состава, как правило, имеют низкий уровень внутренней конфликтности. Однако латентная социальная напряженность, вызываемая идущим переделом жилья, проявляется в некоторых типовых конфликтах, к которым относится и изученный нами «мансардный конфликт».

\section{Формы представления работы}

Результаты исследования будут представлены в виде научного отчета; научных статей; комплектов карт с комментариями для различных органов управления города, районов. Планируется подготовка и издание атласа карт центра Санкт-Петербурга. 


\title{
МИГРАЦИОННАЯ ПОДВИЖНОСТЬ ЭКОНОМИЧЕСКИ АКТИВНОГО НАСЕЛЕНИЯ РОССИЙСКОЙ ПРОВИНЦИИ В КОНТЕКСТЕ ФОРМИРОВАНИЯ НОВЫХ ЖИЗНЕННЫХ СТРАТЕГИЙ ${ }^{1}$
}

\author{
Руководитель проекта: $\quad$ C.В. Рязанцев, к. э н., доцент кафедры экономической теории \\ и регионоведения Ставропольского государственного \\ университета. \\ E-mail: riazan@foramed.ru
}

Сроки реализации проекта: 1 февраля - 31 декабря 2001 г.

Цели и задачи исследования. В период трансформации экономической системы в России появились новые формы трудовой и коммерческой миграции населения. Главной целью исследования стала комплексная оценка трудовой и коммерческой миграции населения в российской провинции. В исследовании дана оценка масштабов трудовой миграции и миграционного движения населения, выявлены их особенности, причины и основные виды, установлено социально-экономическое значение трудовой миграции и «околочелночного» сервиса для конкретного российского региона, выявлено значение трудовой миграции и миграционной подвижности в жизненных стратегиях экономически активного населения Ставропольского края.

В основе исследования лежали две гипотезы:

- трудовая и коммерческая миграция стала достаточно распространенным социальноэкономическим явлением в российской провинции;

- разнообразные виды трудовой и коммерческой миграции стали не только средством адаптации экономически активного населения к новым социально-экономическим условиям, но и средством повышения благосостояния и доходов определенной части населения.

Методика исследования. Использовалось сочетание количественных и качественных методов. Социологический опрос проводился среди трех групп респондентов: индивидуальных предпринимателей - челноков, водителей-дальнобойщиков, маятниковых мигрантов. В общей сложности было опрошено 456 трудовых мигрантов методом случайной выборки и «снежного кома». Учитывая специфику проекта, количественные методы были дополнены качественными методами исследования глубинными интервью с руководителями местных администраций, директорами рынков, трудовыми мигрантами. Был проведен контент-анализ прессы по данной проблеме за 1990-е гг. Отдельным методом исследования стали данные наблюдений за пассажиропотоком в пригородных маршрутах электропоездов и автомобильного транспорта в районе Кавказских Минеральных Вод и Ставрополе.

\section{Основные результаты}

Было установлено, что в настоящее время в Ставрополье трудовая миграция (форма самозанятости, созданная на основе личной инициативы людей при минимальном участии государства) получила достаточно широкое распространение: в ней задействовано примерно 70-100 тыс. человек, или 6-8\% экономически активного населения региона.

\footnotetext{
${ }^{1}$ Проект реализован в рамках программы «Социальная политика: реалии XXI века» (при финансовой поддержке Независимого института социальной политики и Фонда Форда). Грант SP-01-1-02.
} 
Различные формы трудовой и коммерческой миграции имеют важное социальноэкономическое значение: пополняют бюджеты разных уровней, создают новые рабочие места, обеспечивают значительную часть населения российских регионов доступными по цене товарами и продуктами.

Исследование позволило установить, что в трудовую и коммерческую миграцию вовлечены широкие слои населения - это люди различных профессий, социального статуса, пола, возраста и уровня образования. На первых порах своего существования она представляла собой форму адаптации населения к новым социально-экономическим условиям, постепенно превратившись в реальный, эффективный, а в некоторых случаях единственно возможный способ повышения уровня и качества жизни для определенной части населения.

Несмотря на их высокий, в сравнении со многими категориями населения, уровень доходов, трудовые мигранты, в том числе челноки, пока не стали основной группой для формирования среднего класса. Многие из них - при относительно высоком материальном достатке - подверглись деквалификации, испытывают душевный дискомфорт, стрессы, ухудшили состояние своего здоровья.

В этой ситуации государству необходимо создавать благоприятные условия для реализации частной инициативы через соответствующие законы и практику. Государство должно поддерживать предпринимателей, пытающихся самостоятельно обеспечить себя и свои семьи, не столько материально, сколько создавая прозрачные условия и четкие законодательные рамки для данного вида деятельности. Сами предприниматели говорят о необходимости учреждения краевого координационного совета по проблемам малого, среднего и крупного бизнеса при губернаторе, создания нормального налогового законодательства, установления прозрачных отношений между государством и предпринимателями.

Исследование позволило выявить проблемы, стоящие сегодня перед трудовыми мигрантами, обозначить возможные приоритеты государственной политики в этой сфере, привлечь внимание общественности и государственных институтов к такому социальному феномену, как трудовая миграция.

Основные результаты проекта опубликованы в журнале «Народонаселение» (№ 1 за 2002 г.). В настоящее время автором проекта и его коллегами готовится к публикации коллективная монографии «Региональный рынок труда в условиях социальноэкономической трансформации (на материалах Южного Федерального округа), включающая раздел «Влияние миграции на региональный рынок труда» с материалами данного проекта в полном варианте. 


\title{
Учебные программы
}

$\boldsymbol{V} \boldsymbol{R}$ Мы размещаем учебную программу Пола Димаджио «Экономическая социология». Профессор Димаджио - один из самых известных людей в экономической социологии. Это специалист потрясающе широкого диапазона. Он известен работами по социологии организаций и новому институционализму, экономической социологии культуры и когнитивной социологии. Его программа заслуживает самого пристального внимания.

\author{
ECONOMIC SOCIOLOGY ${ }^{1}$ \\ Paul DiMaggio \\ Department of Sociology \\ 2-N-2 Green Hall \\ Princeton University \\ Email: dimaggio@princeton.edu
}

\section{Fall 1996}

Objective. The objective of this mini-seminar is to introduce major themes and some major works in economic sociology, and thus to provide an overview for the curious and a platform from which the student who may wish to take comprehensives or teach a course in this area can pursue the topic independently.

Focus. Because this is a mini-seminar, the reading list is highly selective. (A list of supplementary readings will be provided when the seminar meets for those who wish to pursue certain themes further.) Three consequential curricular decision:

1) I have chosen to emphasize major contemporary issues and debates, at the cost of excluding the rich classical literature in sociology, political economy, and economics. (One could build an entire course around economic sociologies of Marx, Weber, Simmel, Veblen, Pareto, Commons, Parsons and Schumpeter, none of whom receive much attention below.)

2) Because scarcity and choice enter into everything that social scientists study, there is an arbitrary element in defining the subject matter of this emerging «subfield». I have largely omitted certain areas of sociology that, while dealing with economic themes and influenced by work in economics, are well-established subfields in their own right and therefore covered by other parts of the Department's curriculum (e.g., the sociology of labor markets, organizational sociology, and the sociology of the family). Instead I have emphasized those areas that are most clearly economic sociology's «home turf», and where sociological work highlights the contrast between economic and sociological ways of seeing: the sociology of exchange (mo re broadly, economic behavior); and the sociology of markets (more broadly, economic institutions).

3) Most, though far from all, of the readings are by sociologists. This is an interdisciplinary field, however, and, were the course longer, there would be more by economists, psychologists, anthropologists and political scientists.

The first week's readings provide an overview of the field, key themes within it, and a few major works. The next two weeks explore orientations to exchange, both the debate over the nature and limits of rational choice, on the one hand, and work on the prominent topic of the social «embeddedness» of economic behavior. The two weeks that follow address economic

\footnotetext{
${ }^{1}$ http://www.princeton.edu/ sociolog/grad/courses/fall1996/soc520p.html
} 
institutions: first, institutional prerequisites of markets and, second, studies of markets as concrete organizational forms. The seminar's final week takes on a topic that connects individuals and the institutions and without which exchange is impossible: trust, its origins, its distribution, and effects.

Requirements. The course is a seminar. Students are expected to do the reading thoroughly in advance of the class meeting for which it is assigned and to participate actively in class meetings. Emphasis is on mastering and responding critically and creatively to the seminar's material. No term paper or research project is required.

There are three kinds of readings. Required readings represent the minimum necessary for participating in the seminar. I hope that most of you will choose to read at least some recommended readings for each week (smaller type), as well, for they are of high quality and cover significant themes that the required readings do not. Students who enroll in or audit regularly the seminar will also receive a set of supplementary readings for each week. These are primarily intended as resources for students who wish to pursue further studies in this field.

In addition to reading and participation, two other kinds of work are required:

a) each student will prepare memoranda of 2-4 pages on the readings prior to at least three of the weekly meetings. Memoranda should be regarded as writing and thinking exercises, not as finished products. Use them to engage each week's materials and respond with questions, criticisms and new ideas that they suggest. Memoranda should be used to develop ideas informally over time and to put into words impressions that seem worth developing. Because I will read them each week, they also provide an opportunity to receive individualized feedback.

b) for each of weeks 2-5, two students will prepare brief presentations

c) student will prepare a «lead memo» (2-4 pp., to be in the seminar box by 5pm Monday evening and read by everyone before class), describing the major themes of the week's readings and identifying major unresolved issues in the form of a list of questions for discussion.

d) A second student will prepare a «research memo» (2-4 pp., by 5pm previous Monday in seminar box) which can be one of two things: a brief account of an outstanding problem from the readings and a preliminary design of a study to solve it; OR a memo introducing and describing an existing data set relevant to the week's readings and suggesting some possible uses. (The directories from ICPSR and a comparable directory from the Netherlands, as well as resources at the Social Science Research Center data library at Firestone, can be used to identify likely data sets.)

Enrollment is open to any graduate student in Sociology, any other social-science department or the Woodrow Wilson school. No background in economics is required.

\section{Readings}

\section{Week 1: Introduction to Economic Sociology}

Required: The required readings provide both overview and a sample of directions in which economic sociologists have wandered. Smelser and Swedberg's introductory chapter to their Handbook provides a fine overview of the field. Granovetter's classic manifesto, originally entitled «On the Social Embeddedness of Economic Action», asserts the need to situate economic behavior in its social context. Zelizer's fine essay challenges persuasively conventional claims that markets inexorably subordinate e very aspect of human existence and develops a related agenda. Baron and Hannan skeptically interpret the impact of economics on sociology for an audience of economists. 
- Smelser, Neil and Richard Swedberg. The Sociological Perspective on the Economy, in: Smelser, Neil and Richard Swedberg (eds.) Handbook of Economic Sociology. N.Y.: Russell Sage Foundation, 1994. P. 3-26.

- Granovetter, Mark. Economic Action and Social Structure: The Problem of Embeddedness, American Journal of Sociology (1985). Vol. 91. P. 481-510. Also in: Granovetter, Mark and Richard Swedberg (eds.) The Sociology of Economic Life. Boulder, Col.: Westview Press, 1992. P. 53-84.

- Zelizer, Viviana A. Beyond the Polemics of the Market: Establishing a Theoretical and Empirical Agenda, Sociological Forum (1988). Vol. 3. P. 614-34.

- Baron, James and Michael T. Hannan. The Impact of Economics on Contemporary Sociology, Journal of Economic Literature (1994). Vol. 32. P. 1111-46.

Recommended: Beckert argues that a distinctive view of uncertainty is at the core of the difference between economics and economic sociology. Etzioni's essay provides a different research agenda and critique of economic reasoning than those in the required readings. Hirsch et al. give a quasi-ethnographic overview of stylistic and cultural differences between (stylized versions of) economics and sociology. Economist Pollack and sociologist/demographer Watkins discuss similar issues in the context of a particular substantive area. Sociologists Lindenberg and economist Frey expand the notion of rational choice to incorporate significant sociological concepts. Block raises questions about categories economists use to analyze macro-economic behavior. Sen, an accomplished economist, raises fundamental questions about the psychological foundations of homo economics.

- Beckert, Jens. What is Sociological About Economic Sociology? Theory and Society (1996).

- Etzioni, Amitai. Opening the Preferences: A Socio-Economic Research Agenda, Journal of Behavioral Economics (1985). Vol. 14. P. 183-205.

- DiMaggio, Paul. Culture and Economy, in: Smelser, Neil and Richard Swedberg (eds.) Handbook of Economic Sociology. P. 27-57.

- Hirsch, Paul, Stuart Michaels and Ray Friedman. Clean Models vs. Dirty Hands: Why Economics is Different from Sociology, in: Zukin, Sharon and Paul DiMaggio (eds.) Structures of Capital: The Social Organization of the Economy. P. 39-56. Also in Theory and Society (1986). Vol. 15, special double issue on economic sociology.

- Block, Block. Political Choice and the Multiple 'Logics' of Capital, in: Zukin, Sharon and Paul DiMaggio (eds.) Structures of Capital: The Social Organization of the Economy. N.Y.: Cambridge University Press, 1990. P. 293-310. Also in Theory and Society (1986). Vol. 15, special double issue on economic sociology.

- Lindenberg, Siegwart and Bruno S. Frey. Alternatives, Frames, and Relative Prices: A Broader View of Rational Choice Theory, Acta Sociologica (1993). Vol. 36. P. 191-205.

- Polanyi, Karl. The Economy as Instituted Process, in: Granovetter, Mark and Richard Swedberg (eds.) The Sociology of Economic Life. P. 29-52.

- Pollack, Robert A. and Susan Cotts Watkins. Cultural and Economic Approaches to Fertility: A Proper Marriage or a Mésalliance? Population and Development Quarterly (1993).

- Sen, Amartya. Rational Fools: A Critique of the Behavioral Foundations of Economic Theory, Philosophy and Public Affairs (1977). Vol. 6. P. 317-44.

\section{Week 2: Orientations to Exchange}


Required: A fundamental tenet of economic sociology is that orientations to exchange vary both between and within cultures. By orientations to exchange, I refer to the extent to which individuals behave like homo economicus (that rational, self-interested, optimizer) or, to put it another way, the extent to which people behave as if they have no role relations that constrain their pursuit of personal gratification. In an essay originally entitled «Patching Up the Rational Model». Geertz writes a bout a system of exchange governed by customs and norms quite different from our own. Kahneman (Princeton Psychology) demonstrates that widespread norms of fairness cause popular economic judgments to deviate wildly from the dictates of rationality. Miller and Ratner, also Princeton psychologists, ask, not, «are people rational», but rather, «what difference does it make that people think people are rational». Sears and Funk, two political scientists, summarize an important research program that demonstrates that rather narrow limits within which economic self-interest dominates political opinions and voting behavior. Wuthnow's chapter (from a longer book) focusses on the meaning that people attribute to economic action and the role of such action in their lives.

- Etzioni, Amitai. The Moral Dimension: Towards a New Economics. N.Y.: The Free Press, 1988. Chs. 8-11 (P. 136-98).

- Geertz, Clifford. The Bazaar Economy: Information and Search in Peasant Marketing, in: Granovetter, Mark and Richard Swedberg (eds.) The Sociology of Economic Life. P. 225-32. Also in: American Economic Review (1978). Vol. 68. P. 28-32.

- Kahneman, Daniel, Jack L. Knetsch and Richard Thaler. Fairness as a Constraint on Profit Seeking: Entitlements in the Market, American Economic Review (1986). Vol. 76. P. 72841.

- Miller, Dale T. and Rebecca K. Ratner. The Power of the Myth of Self-Interest, in: Montada, L. and M.J. Lerner (eds.) Current Societal Issues in Justice. N.Y.: Plenum Press, 1996.

- Sears David, O. and Carolyn L. Funk. Self-Interest in Americans' Political Opinions, in: Mansbridge, Jane J. (ed.) Beyond Self-Interest. Chicago: University of Chicago Press, 1990. P. 147-70.

- Wuthnow, Robert. Getting and Spending, in his: Poor Richard's Principle. Princeton: Princeton University Press, 1996. P. 168-205.

Recommended: You really should read Lane's book some day: it is a synoptic, erudite synthesis of a huge range of social science research with the ambitious aim of explaining the effects of a market economy on the quality of life (social relations, values, happiness, innovativeness, sense of autonomy, etc.) of the people who live in it. The brief snatch of Bourdieu sets out his notion of habitus, a set of instilled orientations that shape the different ways that different kinds of people pursue self-interest. The Marwell/Ames and Frank et al. papers report surprising findings from a series of game-theoretically inspired experiments that illustrate the effects of culture and socialization on exchange orientations. Frank, an unorthodox economist, summarizes his two fascinating books, which look, respectively, at the role of reference groups in economic action and at the functions of emotions in «rational» market exchange. (Frank's paper, "If homo economicus...», is the full version of the previous paper's argument about conscience.) Kahneman writes about additional cognitive deviations from rationality. Wuthnow's book provides an illuminating interpretive analysis of the cultural construction of money and economic action in the contemporary U.S.

- Bourdieu, Pierre. Structures, Habitus, Practices, in his: The Logic of Practice. Stanford: Stanford University Press, 1990. P. 52-65.

- Frank, Robert H. If Homo Economicus Could Choose His Own Utility Function Would He Want One with A Conscience? American Economic Review (1987). Vol. 77. P. 595-604. 
- Frank, Robert H., Tom Gilovich and D.T. Regan. Does Studying Economics Inhibit Cooperation? Journal of Economic Perspectives (1993). Vol. 7. P. 159-71.

- $\quad$ Frank, Robert H. Rethinking Rational Choice, in: Friedland, Roger and A.F.Robertson (eds.) Beyond the Marketplace: Rethinking Economy and Society. N.Y.: Aldine de Gruyter, 1990. P. 53-87.

- Kahneman, Daniel. New Challenges to the Rationality Assumption, Journal of Institutional and Theoretical Economics (1994). Vol. 150. P. 18-36.

- Lane, Robert E. The Market Experience. N.Y.: Cambridge University Press, 1991. Chs.3-7 (P. 41-136).

- Marwell, Gerald and Ruth E. Ames. Economists Free Ride: Does Anyone Else? Journal of Public Economics (1981). Vol 13. P. 295-310.

- Wuthnow, Robert. The Cultural Construction of Material Life, Part 2 (P. 83-205) in his: Poor Richard's Principle. Princeton: Princeton University Press, 1996.

\section{Week 3: Varieties of Embeddedness}

Required: Economic sociologists like to demonstrate that concepts that economists regard as unproblematic are glazed in the oast of social interaction. Since the publication of Granovetter's paper (week 1), probably the most-cited work in economic sociology, the $\mathrm{k}$ ey metaphor for discussing such things has been «social embeddedness». Like many powerful and evocative concepts, «embeddedness» requires domestication (parsing, unpacking, operationalizing) to become fully useful. This week's readings begin with Portes and Sensenbrenner's paper, which does this very nicely indeed. Nee and Ingram's essay sets out a view of embeddedness that tacks a bit more towards the rational-choice approach. Zelizer explores the social and cultural embeddedness of price and value in her study of the changing value of children. Putnam discusses the role of a particularly benign version of «embeddedness» (called into questioned by Portes and Landolfi in their rejoinder) in enhancing communities' economic and political welfare and worries about its disappearance in the U.S.

- Portes, Alejandro and Julia Sensenbrenner. Embeddedness and Immigration: Notes on the Social Determinants of Economic Action, American Journal of Sociology (1993). Vol. 98. P. 1320-50.

- Nee, Victor and Paul Ingram. Embeddedness and Beyond: Institutions, Exchange, and Social Structure, in: Brinton, Mary and Victor Nee (eds.) The New Institutionalism in Sociology. N.Y.: Russell Sage Foundation, 2001 (1998).

- Zelizer, Viviana. Pricing the Priceless Child: The Changing Social Value of Children. N.Y.: Basic Books, 1985. Introduction - Ch. 3 (P. 3-112).

- Putnam, Robert. The Strange Disappearance of Civic America, The American Prospect (Winter 1996). P. 34-48.

- $\quad$ Portes, Alejandro and Patricia Landolt. The Downside of Social Capital, American Prospect, (May-June 1996). P. 18-21 ff.

Recommended: The recommended readings include two papers on social influences on prices, a key economic category. The paper by Blinder, a Princeton economist, noted that nothing in neoclassical theory leads one to expect the finding that prices are «sticky»; (ratchet upward), so he asked businesspeople how they set prices; sociologists will find their answers comforting. Smith's ethnographic study of many kinds of auctions (a form privileged in economic theory) describes the strictly social factors that shape the valuations that auctions yield. Ibarra and Smith-Lovin summarize findings on the effect of gender-correlated variations in embeddedness 
on women's career chances. Two papers describe the embeddedness of industrial organization: like Portes and Sensenbrenner, Uzzi refines the notion of embeddedness as he uses it to explain economic outcomes in the rag trade. Writing on regional economies, Romo and Schwartz report surprising findings on corporate flight and disinvestment and develop an «embeddedness» explanation to explains anomalies that neoclassical models cannot. Saxenian asks why two very similar high-tech industrial districts (California's Silicon Valley and Boston's Rte. 128) had such different fates during the 1980s, and finds differences in social relations to be the reason. Padgett and Ansell's elegant study of the Medicis and their peers specifies the consequences of particular forms and combinations of embeddedness in the Florentine elite. Zelizer's paper demonstrates that even money, that supposedly neutral medium of exchange, takes on the character of the relations in which it is embedded.

- Blinder, Alan S. Why are Prices Sticky? Preliminary Results from an Interview Study, American Economics Association Papers and Proceedings (May 1991).

- Ibarra, Herminia and Lynn Smith-Lovin. New Directions in Social Network Research on Gender and Organizational Careers, in: Jackson, Susan and Cary Cooper (eds.) Handbook of Organizational Behavior, 1997.

- Padgett, John and Chris Ansell. Robust Action and the Rise of the Medici, American Journal of Sociology (1992). Vol. 98. P. 1259-1330.

- Romo, Frank P. and Michael Schwartz. The Structural Embeddedness of Business Decisions: The Migration of Manufacturing Plants in New York State, 1960-1985, American Sociological Review (1995). Vol. 60. P. 874-907.

- Saxenian, AnnaLee. In Search of Power: the Organization of Business Interests in Silicon Valley and Route 128, Economy and Society (1989). Vol. 18. P. 25-70.

- Smith, Charles W. What Auctions Tell us About Values, in his: Auctions: The Social Construction of Value. Berkeley: University of California Press, 1989. Ch. 8 (P. 162-84).

- Uzzi, Brian. The Sources and Consequences of Embeddedness for the Economic Performance of Organizations: The Network Effect, American Sociological Review (1996). Vol. 61. P. 674-98.

- Zelizer, Viviana. The Social Meaning of Money, American Journal of Sociology (1989). Vol. 95. P. 342-77.

\section{Week 4: Institutional Prerequisites of Markets}

Required: A key tenet of economic sociology, which economic historians are coming to share, is that markets, far from representing a universal category, are an historically specific form that can only exist under certain cultural and institutional conditions. North's essay summarizes a rational-choice explanation of the emergence of economic institutions that is becoming increasingly influential among sociologists and historians. Economic historian Greif brings culture into the mix. Campbell and Lindberg examine the role of an important legal foundation of market economies - property rights - from a sociological perspective. The Oberschall/Leifer paper is a nice review article that criticizes the use of economic reasoning under many circumstances: we can argue about whether the shoe fits any of the other readings. One of the best ways to understand the cultural and institutional specificity of markets is to see how they vary over time and space. Hamilton and Biggart's paper describes the very different types of market systems in the Far East. Analyzing the reaction of several industrial societies to the Depression, Dobbin demonstrates that national variations in economic «rationality» lead to different constructions of economic problems and different solutions. 
- North, Douglass. Institutions and Their Consequences for Economic Performance, in: Schweers Cook, Karen and Margaret Levi (eds.) The Limits of Rationality. Chicago: University of Chicago Press, 1990. P. 383-401.

- Greif, Avner. Cultural Beliefs and the Organization of Society, Journal of Political Economy (1994). Vol. 102. P. 912-50.

- Overschall, Anthony and Eric M. Leifer. Efficiency and Social Institutions: Uses and Misuses of Economic Reasoning in Sociology, Annual Review of Sociology (1986). Vol. 12. P. 233-53.

- Campbell, John and Leon Lindberg. Property Rights and the Organization of Economic Activity by the State, American Sociological Review (1990). Vol. 55.

- Dobbin, Frank. The Social Construction of the Great Depression: Industrial Policy During the 1930s in the United States, Britain, and France, Theory and Society (1993). Vol. 22. P. 156.

- Hamilton, Gary and Nicole Woolsey Biggart, Market, Culture and Authority: A Comparative Analysis of Management and Organization in the Far East, American Journal of Sociology, supplementary special issue on economics and sociology (1988). Vol. 94. P. S52S94. Also in: Granovetter, Marc and Richard Swedberg (eds.). The Sociology of Economic Life. P. 181-221.

Recommended: Although his Protestant Ethic argument is better known, Weber's more serious «last» theory of capitalism is better, and is narrated with great clarity by Collins. The recommended North reading permits him to develop his perspective in more detail. The Smith excerpt describes the emergence of markets at a more «micro» level. Dobbin's book develops his argument about distinctive rationalities in the context of a careful historical examination of how different states encouraged the growth of national railroad industries and how they regulated them once they emerged. The paper by Ellickson, a legal scholar, reports a fascinating study of economic dispute resolution among California cattle farmers that challenges both economic and sociological approaches to economic institution. Sabel also addresses the emergence of informal economic institutions in contemporary industrial societies. Fligstein and Iona Mara-Drita analyze the effort to construct a single market in the European Union. The fall of socialism in Eastern Europe provides an unequalled laboratory setting in which to study the institutionalization of market systems (or perhaps failed attempts to do so): Stark's paper describes several such systems, argues that approaches must and should vary, and introduces the important concept of «path dependence».

- North, Douglass C. Institutions, Institutional Change and Economic Performance. N.Y.: Cambridge University Press, 1990. Chs. 1-2 (P. 3-16).

- Smith, Charles W. Creating and Maintaining Auction Communities, in his: Auctions: The Social Construction of Value. Ch. 3 (P. 51-79).

- Collins, Randall. Weber's Last Theory of Capitalism: A Systematization, American Sociological Review (1980). P. 925-42. Also in: Granovetter, Mark and Richard Swedberg (eds.) The Sociology of Economic Life. P. 85-110.

- Dobbin, Frank. Forging Industrial Policy: The United States, Britain and France in the Railway Age. N.Y.: Cambridge University Press, 1994.

- Ellickson, Robert C. Of Coase and Cattle: Dispute Resolution among Neighbors in Shasta County, 38 Stanford Law Review 623 (1986). 
- Fligstein, Neil and Iona Mara-Drita. How to Make a Market: Reflections on the Attempt to Create a Single Market in the European Union, American Journal of Sociology (1996). Vol. 102. P. 1-33.

- Sabel, Charles F. Learning by Monitoring: The Institutions of Economic Development, in: Smelser, Neil and Richard Swedberg (eds.) The Handbook of Economic Sociology. Princeton: Princeton University Press and Russell Sage Foundation, 1994. P. 137-65.

- Stark, David. Path Dependence and Privatization Strategies in East Central Europe, East European Politics and Societies (1992). Vol. 6. P. 17-54.

\section{Week 5: The Social Organization of Markets}

Another basic feature of the sociological approach to the economy is to analyze markets not as theoretical constructs but as concrete social structures: actors transacting in patterned ways with foreseeable consequences. This very quickly leads one away from such neoclassical shortcuts as fungibility of products of different sellers, full information, freedom to trade, and prices as signals. Burt focusses on constraints on information and choice, emphasizing the ways in which distinctive relationships among buyers and sellers influence the relative market power, and thus profits, of each. Williamson provides an ingenious and influential, if controversial, economic theory of the conditions under which different forms of market and hierarchy develop. Eccles and White demonstrate the political functions of «markets» (a topic Williamson neglects) and the importance of variations in rule systems in a study of the construction and consequences of fashionable «internal markets» within large firms. The two final readings are ambitious efforts to identify and analyze large-scale changes in industrial the organization of firms and markets in the U.S. and Eastern Europe, respectively.

\section{Required:}

- Burt, Ronald S. Turning a Profit, in his: Structural Holes, the Social Structure of Competition. Cambridge: Harvard University Press, 1992. Ch. 3 (P. 82-114).

- Williamson, Oliver. Comparative Economic Organization: The Analysis of Discrete Structural Alternatives, Administrative Science Quarterly (1991). Vol. 36. P. 269-96.

- Eccles, Robert and Harrison C. White. Price and Authority in Inter-Profit-Center Transactions, American Journal of Sociology, supplementary special issue on economics and sociology (1988), Vol. 94. P. S17-S51.

- Powell, Walter W. Neither Market Nor Hierarchy: Network Forms of Social Organization, Research in Organizational Behavior (1990). Vol. 12. P. 295-336.

- Stark, David. «Heterarchy: Asset Ambiguity, Organizational Innovation, and the Postsocialist Firm». Presented at Session on the Firm in the 21st Century, ASA meetings, New York City, 1996.

Recommended: Carroll and Harrison use simulation modelling to argue that economic competition does not yield the survival of the «most efficient». Leifer and White summarize White's brilliant but difficult AJS paper, «Where do Markets Come From». The central insight is that most markets represent role systems, where sellers maintain unique identities/niches into which they jockey as a result of close mutual observation. From this they develop generalizations about the sets of parameters (product qualities, output quantities, and terms of trade) that can and cannot sustain viable markets. Other recommended readings include a probing theoretical piece by Bradach and Eccles; and five fine empirical studies: Baker and Faulkner on the organization o $\mathrm{f}$ conspiracy in markets; Davis et al. on the deinstitutionalization of conglomerate organization; Gerlach on the organization of the Japanese economy; and Mizruchi/Stearns on political and social influences on capital markets. Nee's and Stark's papers de scribe the transformation of 
economic systems in China and Eastern Europe, respectively, with particular attention to the link between economic interest and political resources.

- Carroll, Glenn R. and J. Richard Harrison. On the Historical Efficiency of Competition Between Organizational Populations, American Journal of Sociology (1994). Vol. 100. P. 720-49.

- Leifer, Eric and Harrison C. White. A Structural Approach to Markets, in: Mizruchi, Mark and Michael Schwartz (eds.) Structural Analysis of Business. Cambridge: Cambridge University Press, 1987. P. 85-108.

- Bradach, Jeffrey L. and Robert G. Eccles. Price, Authority and Trust: From Ideal Types to Plural Forms, Annual Review of Sociology (1989). Vol. 15. P. 97-118.

- Davis, Gerald F., Kristina A. Diekmann, and Catherine H. Tinsley. The Decline and Fall of the Conglomerate Firm in the 1980s: The Deinstitutionalization of an Organizational Form, American Sociological Review (1994). P. 547-71.

- Baker, Wayne and Robert R. Faulkner. The Social Organization of Conspiracy: Illegal Networks in the Heavy Electrical Equipment Industry, American Sociological Review (1993). Vol. 58. P. 837-60.

- Gerlach, Michael. The Japanese Corporate Network, Administrative Science Quarterly (1992). Vol. 37. P. 105-39.

- Mizruchi, Mark and Linda Brewster Stearns. A Longitudinal Study of Borrowing by Large American Corporations, Administrative. Science Quarterly (1994). Vol. 38. P. 118-40.

- Nee, Victor. Organizational Dynamics of Market Transitions: Hybrid Forms, Property Rights and the Mixed Economy in China, Administrative Science Quarterly (1993). Vol. 37. P. 1-27.

- Stark, David. Recombinant Property in Eastern European Capitalism, American Journal of Sociology (1996). Vol. 101. P. 993-1027.

\section{Week 6: Trust}

Required: Trust is a crucial concept in economic sociology because it is where behavioral questions about orientations to exchange meet up with organizational concerns. Under what conditions do exchange partners trust one another to obey the rules of the game, and what structures or rules of the game encourage that kind of trust? Answering these questions is complicated by the fact that trust is defined in so many ways. Macauley's classic study of buyersupplier relations demonstrates that trust is more common than most economic theories would suggest. Sabel's essay, based on work with cooperative ventures among for-profit enterprises and public-private partnerships, portrays trust as a fragile yet attainable product of political relations. The Yamagashis offer an important distinction between commitment and trust and use it to explain intriguing differences in the results of laboratory experiment on exchange in the U.S. and Japan. Zucker's institutional view argues that the modern economy is based on the substitution of organizational and legal-rational legitimacy for interpersonal trust. Williamson's paper analyzes trust from the perspective of transaction-cost economics.

- Macauley, Stewart. Non-Contractual Relations in Business: A Preliminary Study, in: Granovetter, Mark and Richard Swedberg (eds.) The Sociology of Economic Life. P. 265-84. Also in: American Sociological Review (1963). Vol. 28. P. 55-67.

- Sabel, Charles. Studied Trust: Building New Forms of Cooperation in a Volatile Economy, in: Pyke, Frank and Werner Sengenberger (eds.) Industrial Districts and Local Economic Regeneration. Geneva: International Institute for Labor Studies, 1992. P. 215-50. 
- Yamagishi, T. and M. Yamagishi. Trust and Commitment in the United States and Japan, Motivation and Emotion (1994). Vol. 18. P. 129-66.

- Zucker, Lynne G. Production of Trust: Institutional Sources of Economic Structure, 18401920, Research on Organizational Behavior (1986). Vol. 8. P. 53-111.

- Williamson, Oliver E. Calculativeness, Trust, and Economic Organization, Journal of Law and Economics (1993). Vol. 36. P. 453-86.

Recommended: Burt and Knez offer an intriguing amalgam of sociological and game-theoretic insights, Garfinkel presents a view of trust, as based in routine and in people's shared interest in producing order. The excerpt from Coleman's rational-choice manifesto reflects a different, theoretical approach to trust. Dore presents yet another view of trust (as «goodwill» in exchange) in the context of comparison of Japanese and British economic systems. Kollock's paper uses an experimental approach to examine the emergence of trust.

- Burt, Ronald S. and Marc Knez. Kinds of Third-Party Effects on Trust. Chicago: University of Chicago Press, 1994.

- Garfinkel, Harold. Studies of the Routine Grounds of Everyday Activities, in his: Studies in Ethnomethodology. Cambridge: Polity, 1987 [1967]. Ch. 2 (P. 35-75).

- Dore, Ronald. Goodwill and the Spirit of Market Capitalism, British Journal of Sociology (1983). Vol. 34. P. 459-82. Also in: Granovetter, Mark and Richard Swedberg (eds.) The Sociology of Economic Life. P. 159-180.

- Coleman, James S. Foundations of Social Theory. Cambridge: Harvard University Press, 1990. Ch. 5 (P. 91-118) and Ch. 8 (P. 175-96).

- Kollock, Peter. The Emergence of Exchange Structures: An Experimental Study of Uncertainty, Commitment and Trust, American Journal of Sociology (1994). Vol. 100. P. 313-45. 


\title{
Конференции
}

\section{КОНФЕРЕНЦИЯ, ПОСВЯЩЕННАЯ 10-ЛЕТИЮ «РОССИЙСКОГО ЭКОНОМИЧЕСКОГО БАРОМЕТРА»}

\author{
16-18 апреля 2002 г., Москва \\ Баширова И.А.
}

Email: bachirova@imemo.ru; ibachirova@mail.ru

16-18 апреля 2002 г. в Москве в Институте мировой экономики и международных отношений РАН проходила международная конференция «Рыночная экономика в России: ожидания и действительность», посвященная 10-летию начала осуществления исследовательской программы «Российский Экономический Барометр» и выходу в свет первого номера одноименного (англоязычного) бюллетеня «The Russian Economic Barometer».

Основной научной целью конференции было проанализировать экономическую систему, сложившуюся в России в результате реформ, с точки зрения ее соответствия (или несоответствия) традиционным представлениям о рыночном хозяйстве и выделить те ее особенности (прежде всего - на микроуровне), которые имеют устойчивый долговременный характер.

В конференции приняли участие экономисты из ряда российских исследовательских центров, регулярно работающих с опросной статистикой РЭБ, а также представители стран ближнего и дальнего зарубежья. Всего было заслушано свыше 30 докладов, сгруппированных по 6 последовательным секциям (сессиям).

- Экономические реформы: общая характеристика.

- Корпоративное управление.

- Рынки труда и социальная политика.

- Опыт стран СНГ.

- Тенденции хозяйственного развития и бартер.

- Вопросы методологии опросных исследований (круглый стол).

Выступившие на открытии конференции директор Института экономики РАН академик Л.И. Абалкин, научный руководитель ГУ-ВШЭ профессор Е.Г.Ясин и академик B.А. Мартынов поздравили коллектив РЭБ с юбилеем, отметили принципиальную важность проводимых исследований, уникальность информации, регулярно собираемой в течение столь продолжительного периода времени. Параллельно был высказан ряд замечаний и предложений (Л.И. Абалкиным) в связи с появлением в 2001 г. русскоязычной версии бюллетеня.

Выступление члена-корреспондента РАН В.М. Полтеровича было посвящено анализу недавних изменений в системе государственного управления и проблеме выбора рациональной стратегии институциональных преобразований с учетом особенностей гражданской культуры. Многочисленные исследования подтверждают тезис о том, что трудности широкомасштабных реформ в значительной мере связаны с недостаточным вниманием к институциональному строительству и недооценкой роли государства. На основе сопоставления элементов гражданской культуры в России и других странах автор приходит к выводу, что трудности трансплантации рыночных институтов в нашем случае связаны прежде всего с двумя определяющими чертами российской гражданской культуры, унаследованными от советского периода: патернализмом и «привычкой к нарушению правил», укоренившейся в результате их частого изменения и произвольного применения властью. 
В.В. Радаев (ГУ-ВШЭ) коснулся весьма актуальной и очень сложной темы выхода из «тени» предприятий российского бизнеса. Возможно ли продвижение в сторону легализации, и как должны строиться отношения между представителями бизнеса и органами государственной власти? Эти вопросы рассматривались на основе данных, собранных в результате серии фокусированных интервью с руководителями компаний импортеров электробытовой и компьютерной техники. Предложенные ответы можно охарактеризовать как осторожно-оптимистические в случае, если политика государства в этой сфере будет последовательной.

Анализу «цепей» [chains] и их роли в организации бизнеса на Западе и в России посвятил свой доклад профессор Ольборгского Университета О. Соренсен (Дания). Отмечая специфику функционирования «цепей» в России, он обратил особое внимание на проблемы легальности и строгого соблюдения законов, особенно в контексте корпоративного управления. По его мнению, «цепи» играют очень важную роль в решении проблем выживания компаний, особенно - в «ресурсной» части этих проблем.

А.А. Яковлев (ГУ-ВШЭ) отметил, что защита интересов внешних акционеров является необходимым условием повышения эффективности российских предприятий. Российское корпоративное законодательство достаточно развито, но слабо применяется на практике. Отсюда следует необходимость укрепления механизмов правоприменения [enforcement], ужесточения требований по соблюдению прав акционеров, раскрытия информации о деятельности акционерных обществ и т.д. Решение проблем корпоративного управления в России связано не только с усилением давления на «инсайдеров», но и с формированием «правильной мотивации» и созданием системы косвенных позитивных стимулов для «инсайдеров», а также с принятием мер, направленных на снижение издержек, порождаемых законодательством.

Проверке гипотезы о неэффективности корпоративного управления в России (мнение о справедливости которой широко распространено среди экономистов) посвятил свое выступление А.А. Муравьев (РЕЦЭП). Главный вывод его доклада состоит в том, что существует связь между вероятностью замены генерального директора и результатами деятельности компании. Чем хуже работает фирма, тем более вероятна смена руководителя. Таким образом, нельзя говорить, что корпоративное управление в России отсутствует. Оно есть и действует в правильном (в конечном счете) направлении.

Большой интерес вызвала во второй день конференции работа секции социальной политики и рынков труда в РФ. Она открылась докладом А.А. Московской (ИЭ РАН) об эволюции кадровых стратегий промышленных предприятий в 1990-е гг. В результате анализа выяснилось, что кадровая стратегия, сложившаяся система кооперации, корпоративная этика являются весьма значимыми элементами экономической политики предприятий, а эволюция кадровой стратегии осуществляется в направлении повышения взаимосвязи с этой экономической политикой. Налицо два полюса, к которым тяготеет эволюция кадровой стратегии - технократический и корпоративный. Первый предполагает отношение к персоналу как к одному из технических ресурсов производства, объем использования которого и затраты определяются соотношением издержек. Второй основывается на том, что предприятие - это особый институт, в котором достигается сложный баланс технологической кооперации, профессиональных стереотипов, социокультурных образцов и экономических интересов.

O реализации трудового потенциала в условиях переходной экономики говорила И.В. Соболева (ИЭ РАН). Отличительной чертой современного этапа экономического развития является трансформация рынка труда под воздействием научно-технического прогресса и объективных требований социально-экономического развития в направлении роста гибкости и многовариантности складывающихся на нем отношений. Продвижение к постиндустриальной структуре занятости возможно лишь на основе целенаправленной 
политики. Без вмешательства государства, отстаивающего стратегические интересы национальной экономики, и предприятия, и работники устремятся на поиск краткосрочных выгод. Отсутствие действенной перспективной программы структурной перестройки экономики до сих пор делало объективно невозможным продвижение к рациональной структуре занятости. Политика на рынке труда должна быть направлена на весь комплекс проблем, а не только на сдерживание открытой безработицы.

Р.И. Капелюшников (ИМЭМО РАН) представил результаты регрессионного анализа различных показателей опросной статистики РЭБ. Главный вывод его выступления состоит в том, что несмотря на все своеобразие постреформенного периода активность российских промышленных предприятий на рынке труда определяется вполне традиционным фактором - поэтапным приспособлением занятости к желаемому уровню, который, в свою очередь, зависит от спроса на выпускаемую продукцию. Отличие от стран с устоявшейся рыночной экономикой проявляется, прежде всего, в скорости такого приспособления (у нас она заметно ниже). Но само наличие этого адаптивного механизма не подлежит сомнению.

И.А. Денисова (ЦЭМИ РАН) рассказала об эмпирическом исследовании регистрируемой безработицы на региональном рынке труда. Получены интересные результаты относительно влияния уровня образования на длительность безработицы. Подтверждена значимость гендерных и возрастных различий. Результаты подобного анализа особенно важны при разработке программ борьбы с длительной безработицей и с бедностью.

Функции и параметры заработной платы в рыночной экономике России были проанализированы в докладе А.А. Соболевской (ИМЭМО РАН). В странах с развитой рыночной экономикой не только сформировались условия, способствующие росту заработной платы, но и сам рост становится важнейшим фактором экономического развития. Наряду с расширением платежеспособного спроса он обеспечивает прорыв в высокотехнологические отрасли, требующие работников с высокой квалификацией, высоким уровнем образования и производственного опыта. Другим таким фактором оказывается параллельный рост прибыли, которая является источником накопления. Оба эти процесса неразрывно связаны. Сравнивая высокоразвитые капиталистические страны и Россию, автор приходит к выводу, что заработная плата с самого начала вхождения в рынок не стала фактором роста экономики. Ни о каких конкурентоспособности и процветании не может идти речь, если не изменить положения дел с уровнем, дифференциацией и ролью заработной платы в обществе, не восстановить действие всех ее важнейших функций.

Развернутую характеристику потребительского и сберегательного поведения населения России дала в своем докладе Д.Х. Ибрагимова (Фонд «Индекс Потребительских настроений», Центр Развития). В последнее время здесь произошли важные изменения, касающиеся выбора населением форм сбережений. Растет доверие к банковским вкладам. Накопление рублевой наличности становится менее популярным; то же (хотя и в меньшей степени) относится и к наличной валюте. Медленно, но верно развивался потребительский кредит. В целом 2001 г. был весьма благоприятным для населения. Несмотря на нынешнюю паузу покупательной активности, существует достаточно оснований для того, чтобы вторая половина 2002 г. оказалась не хуже соответствующего периода года предыдущего.

Часть докладов на конференции была посвящена анализу экономического положения в странах СНГ. В докладе О. Кузякив (Исследовательский центр EERC-Ukraine), помимо обзора текущей ситуации, была проверена гипотеза о существовании связи между успешностью работы предприятий и структурой их собственности на Украине. Положительного влияния внешних акционеров на успешность работы предприятий пока не зафиксировано. 
Основные характерные черты белорусской экономики обрисовала И. Колесникова (Институт экономики Национальной Академии наук Беларуси). Автор пришла к выводу, что в экономическом росте Белоруссии за период 1996-2000 гг. основную роль сыграли мягкие бюджетные ограничения, стимулирование внутреннего спроса и производства на государственных предприятиях при одновременном накоплении неиспользуемых и устаревающих основных фондов. Т.е. экономический рост носил экстенсивный характер и был кратковременным феноменом. Важнейшим препятствием для дальнейшего развития страны является неспособность стимулировать внутренние сбережения и частные инвестиции, а также привлекать иностранные капиталовложения.

Третий день конференции был посвящен обсуждению тенденций хозяйственного развития, бартеру и методологии опросов. Открыла его С.Б. Авдашева (ГУ-ВШЭ). Она выступила с докладом об интеграционных процессах в промышленности, их формах и перспективах. Среди внешних стимулов к объединению для российских предприятий актуальны три: снижение трансакционных издержек, ликвидация так называемой «двойной надбавки» и усиление рыночной власти (благодаря расширению рыночной доли). Если первый из названных стимулов был характерен для российских предприятий на протяжении всего периода реформирования, то последние два приобрели значение в ходе экономического подъема. В целом ряде случаев интеграционные процессы представляют собой форму адаптации созданных в прежней экономической системе мощностей к условиям рыночного хозяйства. И в этом смысле наблюдаемые процессы не вполне укладываются в традиционные представления о вертикальной/горизонтальной интеграции обычных рыночных фирм.

Анализу последних тенденций в промышленности посвятил свое выступление А.Н. Клепач (Центр развития Российской Федерации). Среди интересных тем его доклада - проблема наличия или отсутствия фиктивных производственных мощностей, т.е. таких, которые уже не могут быть задействованы, но все еще учитываются респондентами при оценке показателя загрузки производственных мощностей. Выяснение этого вопроса имеет большое значение для анализа инвестиционных стимулов предприятий и реальных ограничений на объем их производства.

Особый интерес у всех участников конференции вызвали доклады, посвященные бартеру в России. В докладе С.М. Гуриева (РЭШ, ЦЭФИР) сделана попытка сопоставления эмпирических результатов, полученных при использовании разных подходов к объяснению бартера. Недостатки методологии эмпирического анализа не дают пока оснований утверждать, что экономистам удалось создать полную картину расцвета и заката бартера. Имеющиеся на сегодня модели, по оценке докладчика, все вместе могут объяснить не более половины этого процесса. С одной стороны, в той или иной степени понятны причины и механизмы распространения бартера. С другой стороны, ремонетизация российской экономики может быть как количественными изменениями реакцией экономики на девальвацию и улучшение макроэкономической конъюнктуры, так и качественными - переходом экономики из «плохого» (бартерного) равновесия в «хорошее» (денежное).

Два следующих докладчика остановились на конкретных моделях объяснения бартера. В.Л. Тамбовцев (МГУ) предложил рассматривать бартер в рамках более широкого подхода - как проблему выбора предприятием наиболее выгодных для него контрактных форм торговли. Такой подход, с его точки зрения, не только хорошо согласуется с эмпирическими фактами (в том числе с результатами регрессионных расчетов по опросной статистике РЭБ), но и позволяет равноуспешно и с единых позиций объяснить как рост, так и падение бартерного оборота после дефолта 1998 г.

По мнению С.П. Аукуционека (ИМЭМО РАН), сверхбартер, который наблюдался в России на протяжении 1996-2000 гг., требует для своего анализа новых подходов. 
Традиционные же модели, по самой своей сути, предназначены для описания бартера лишь как маргинального явления. Предложенная докладчиком модель бартерного производства лишена этого недостатка и может быть использована для объяснения очень больших объемов бартера. Оценки автора показывают, что именно бартерное производство давало преобладающую часть бартерного оборота, по меньшей мере, с 1996 по 2000 г.

Опросам предприятий как инструменту экономического исследования и проблеме достоверности результатов и интерпретаций этих опросов был посвящен доклад Т.Г.Долгопятовой (ГУ-ВШЭ). Она отметила, что более чем десятилетний опыт использования микрообследований в российской переходной экономике можно оценить в целом как весьма положительный. Вместе с тем, результатам формализованных опросов, проводимых на широких совокупностях предприятий, часто присуща недостоверность, порождаемая как собственно методологией получения и обработки данных, так и практикой ее применения в условиях ограниченных ресурсов. Существует целый ряд трудно устраняемых источников искажений, которые необходимо учитывать при интерпретации результатов формализованных опросов. Их влияние можно уменьшить, если исследователи опираются одновременно на различные типы микроэкономических данных, включая глубокие и формализованные интервью, анкетирование, пообъектные показатели статистической и бухгалтерской отчетности. В этом контексте регулярные опросы на панельных выборках предприятий (которыми и пользуется в своих исследованиях РЭБ) выглядят как относительно адекватный инструментарий.

Достоверности конъюнктурных опросов был посвящен и доклад Г.Р.Жуковой (Госкомстат России). Она отметила, что дело не только в ошибочной интерпретации получаемых данных, но и в том, насколько сами данные конъюнктурных опросов близки к объективным характеристикам изучаемого процесса или явления. Проверить это очень сложно. Ведь конъюнктурные опросы как раз и призваны восполнить недостающую объективную информацию о состоянии дел в экономике. Госкомстат России представляет в этом отношении благоприятную возможность. Здесь собираются и данные обследований деловой активности промышленных предприятий, и объективные данные деятельности тех же самых предприятий. Поэтому легко проверить, в какой степени два типа данных согласуются друг с другом. Результаты такого сопоставления оказались неожиданными: выяснилось, что от половины до двух третей предприятий вообще не представляют реальной ситуации в отношении объема выпуска и численности занятых. Это ставит перед исследователями серьезные проблемы.

В выступлении С.В. Цухло (ИЭПП) особое внимание было уделено качеству собираемой информации. Результаты его исследований говорят о том, что сами респонденты не слишком доверяют официальным статистическим показателям, предпочитая во многих случаях иметь дело именно с опросной статистикой. Качество последней, в свою очередь, в значительной степени определяется составом респондентов, их положением на предприятии: являются ли они директорами, начальниками отделов, бухгалтерами и т. д.

Интерпретации и качеству респондентских прогнозов был посвящен доклад А. Белянина (РЕЦЭП). Опираясь на результаты исследований, проведенных по данным РЭБ, автор показал, что хотя усредненные по всей выборке прогнозы можно признать сравнительно неплохими, на уровне индивидуальных предприятий картина принципиально иная. Типична ситуация неоправданной самоуверенности респондента, когда он, допуская существенные ошибки в своих предсказаниях, полагает, что они сбываются с высокой степенью вероятности. 


\title{
ПО РЕЗУЛЬТАТАМ РОССИЙСКОГО МОНИТОРИНГА ЭКОНОМИЧЕСКОГО ПОЛОЖЕНИЯ И ЗДОРОВЬЯ НАСЕЛЕНИЯ (RLMS)
}

\author{
14-15 мая 2002 г., Москва \\ Назарова Инна Борисовна, ГУ-ВШЭ
}

Email: nazarova@hse.ru

На конференции присутствовали ученые и представители государственных структур, которые в течение десяти лет используют базу данных RLMS в своей работе, а также заинтересованные исследователи, которые бы хотели начать работать с базой РМЭЗ и ознакомиться с основными результатами исследования за 2001 г. и за период с 1992 г.

Конференция открылась минутой памяти и словами благодарности профессору Майклу Сваффорду, который внес неоценимый вклад в организацию RLMS.

Сотрудники института социологии П.М. Козырева и М.С. Косолапов сделали обзор основных методических принципов проведения RLMS, напомнив историю организации и проведения мониторинга.

Российский мониторинг экономического положения и здоровья населения (РМЭЗ) (Тhe Russian Longitudinal Monitoring Survey - RLMS) проводится с 1992 г. по общенациональной российской выборке и предназначен для изучения различных аспектов экономического положения и здоровья населения России. Обследование охватывает различные группы населения и предоставляет информацию о динамике широкого круга экономических и социальных показателей, характеризующих положение российских домохозяйств и индивидов в условиях переходной экономики. Оно также может быть использовано в качестве панельного обследования, позволяющего проследить судьбу конкретных домохозяйств и индивидов (детей и взрослых) за период с 1992 по 2001 г.

Программа обследования включает информацию о структуре домохозяйств, семейных бюджетах, жилищных условиях, о видах занятости, состоянии здоровья, качестве питания и т.д., а также информацию об инфраструктуре и уровне цен по каждому населенному пункту, в котором проводится обследование.

Обследование проводится Институтом социологии РАН, Институтом питания РАМН, Исследовательским центром «Демоскоп», Исследовательским центром Paragon Research International. Университет штата Северная Каролина в Чапел Хилле выступал в роли координатора на всех этапах осуществления проекта RLMS. Финансирование обследования RLMS предоставлялось Агентством США по международному развитию (АМР США), Национальным институтом здравоохранения, Национальным фондом науки, Всемирным банком, Министерством иностранных дел Швеции и Университетом штата Северная Каролина в Чапел Хилле.

Профессор Барри Попкин (Университет Северной Каролины в Чапел Хилле) сделал доклады о динамике экономического положения населения России и о динамике состояния здоровья и структуры питания населения России (1992-2001 гг.).

Б. Попкин отметил, что в соответствии с результатами исследования за период с декабря 2000 г. по декабрь 2001 г. цены выросли на 18,6\%. Уровень годовой инфляции в течение этого года колебался вокруг 20\%. В период с октября 2000 г. по октябрь 2001 г. реальный совокупный доход домохозяйств увеличился на 18\%, асуммарныерасходы вырослина 13\%.

Уровень безработицы упал до 7,3\% в октябре 2001 г., достигнув самого низкого своего значения за период с конца 1995 г. Показатель безработицы, учитывающий «скрытую безработицу», по последним данным, является самым низким за все время проведения опросов РМЭЗ с 1993 г. 
В октябре 2001 г. уровень бедности был вполовину ниже пика, зафиксированного в 1998 г. В конце 2001 г. в условиях бедности жили менее 30\% детей младше 6 лет.

В октябре 2001 г. задолженности по заработной плате были только у 25\% взрослых работоспособного возраста, что ниже по сравнению с почти двумя третями в ноябре 1998 г.

В период с 2000 по 2001 гг. размер оплаты жилья и коммунальных услуг увеличился почти на $40 \%$, но эти расходы составляют менее $5 \%$ всех расходов. Частота задолженности по оплате жилья и коммунальных услуг в настоящее время составляет $25 \%$. Наиболее часто среди «должников» оказываются домохозяйства, возглавляемые взрослыми работоспособного возраста.

Что касается результатов, связанных с оценкой здоровья и состояния здравоохранения России, то было отмечено, что 90\% респондентов имеют какую-либо медицинскую страховку. Почти 56\% всех обратившихся за медицинской помощью отметили, что неофициально платили за нее деньгами или подарками. Начиная с 1994 г. нехватка денег становится главной причиной невозможности приобретения прописанных лекарств.

После устойчивого снижения, наблюдаемого в 1992-1998 гг., с октября 2000 г. потребление спиртных напитков вновь стало расти. Например, среди подростков в 20002001 гг. его рост составил 35\%. Распространенность курения среди мужчин достигла самого высокого своего уровня $(63,5 \%)$ начиная с момента проведения опросов РМЭЗ в 1992 г.

В связи с тем, что с середины 1990-х гг. в Российской Федерации быстро растет число зарегистрированных случаев ВИЧ/СПИДа, в 2001 г. впервые в опросник РЭМЗ был включен блок, касающийся сексуального поведения населения и заболеваний, передаваемых половым путем.

В своем докладе о сексуальном поведении доктор Вани Ваннаппагари (Университет Северной Каролины в Чапел Хилле) отметила, что средний возраст вступления в половую связь снижается в зависимости от возрастной группы: так, для 41-49-летних это 19,7 лет, для группы 31-40 лет - 18,9 лет, для группы 21-30 лет - 17,4 года и для 14-20-летних 15,9 лет. В ходе исследования было выявлено значительное число респондентов с признаками заболеваний, передающихся половым путем, которые не были диагностированы или пролечены. Один из основных выводов доклада заключался в том, что в России в связи с высоким уровнем заболеваемости есть насущная потребность в просвещении населения, особенно молодежи, об опасности передачи ВИЧ-инфекции.

С докладами выступили также российские ученые, которые активно используют данные мониторинга в своей работе. Л.Н. Овчарова (Независимый институт социальной политики) отметила важность данных РМЭЗ в расчетах, связанных с определением бедности в России. С.М. Гуриев (Российская экономическая школа) использовал данные мониторинга в исследовании трудовой миграции населения России.

Институт питания использует подробные данные о питании, которые предоставляет РМЭЗ, чтобы сделать выводы об изменениях в структуре потребления продуктов питания и возможных изменениях в состоянии здоровья населения России в зависимости от получения необходимых организму белков, элементов и витаминов.

Организаторы исследования еще раз подчеркнули, что данные раундов мониторинга, начиная с 1994 г., находятся в свободном доступе, и все желающие могут использовать эту уникальную базу в своей работе. Подробную информацию об обследовании RLMS, a также сами базы данных можно получить в Интернете: http://www.cpc.unc.edu/rlms или в Институте социологии РАН. 
VR 3-4 апреля 2002 г. состоялась 3-я Ежегодная международная гранд-конференция Государственного университета - Высшей школы экономики «Модернизация экономики России: итоги и перспективы». На пленарном заседании по традиции выступали высшие правительственные чины и олигархи. Мы же обращаем внимание на программу наиболее интересной для нас секции «Институциональные и структурные реформы».

\section{Секция 2}

\section{ИНСТИТУЦИОНАЛЬНЫЕ И СТРУКТУРНЫЕ РЕФОРМЫ 4 апреля (ГУ-ВШЭ)}

\section{Сессия 1. Корпоративное управление и социальная ответственность бизнеса в} переходной экономике - новый взгляд

Председатель - Т.Г. Долгопятова

E. Berglof (SITЕ, ЦЭФИР). Corporate governance reform in transition: The unavoidable tradeoffs (Реформа корпоративного управления в переходный период: неизбежный компромисс).

А.А. Яковлев (ГУ-ВШЭ). Корпоративное управление, реструктуризация предприятий и мотивация собственников.

D. Petkoski (World Bank Institute). Corporate social responsibility and sustainable competitiveness (Корпоративная социальная ответственность и устойчивая конкурентоспособность).

C.A. Масютин (ОАО «Сафоновский электромашиностроительный завод»). Методы оценки и обеспечения инвестиционной привлекательности предприятий в системе корпоративного управления.

Презентация результатов проекта ГУ-ВШЭ «Российская промышленность: институциональное развитие».

Дискуссанты: А.Д. Радыгин, И.А. Розинский

Сессия 2. Институциональное развитие российского бизнеса - реакция на изменение правил

Председатель - В.М. Полтерович

Ю.В. Симачев (Институт комплексных стратегических исследований). Роль банкротства в российской переходной экономике: оценка «состоятельности» института «несостоятельности».

К. Сонин (РЭШ, ЦЭФИР). Банкротство в России: от хорошей теории к хорошей практике, 1998-2002 гг.

J. Litwack, D. Sutherland (OECD). Barriers to Small Business in Russia: evidence from OECD economic survey (Барьеры на пути развития малого предпринимательства в России: результаты обследования OECD).

A.A. Соколов (Институт комплексных стратегических исследований). Интегрированные бизнес-группы России: особенности формирования прав собственности.

Дискуссанты: А.Ю. Чепуренко, С.Б. Авдашева 
Сессия 3. Круглый стол «Политэкономия институциональных преобразований: кому нужны реформы в России»

Ведущий - А.А. Яковлев

Участники: В.М. Полтерович, О.В. Фомичев, Л.Г. Ионин, W. Tompson, А.А. Аузан.

Сессия 4. Новая экономика в России - теория и практика вхождения в постиндустриальное общество

Председатель - Б.В. Кузнецов

A. Watkins (World Bank). From Knowledge to Wealth - Russia and the 21-st Century Knowledge Economy (От знаний к благосостоянию - Россия и экономика знаний XXI века).

В.Л. Иноземцев (Центр исследований постиндустриального общества). Кризис модели догоняющего развития и место России в мировой экономике.

Ю.Е. Хохлов, С.Б. Шапошник (Институт развития информационного общества). Проблемы формирования национальной инновационной системы.

П.А. Панов (IBS). Эффективная конкуренция в экономике, преобразованной новыми технологиями.

Дискуссанты: М. Горский, Л.М. Гохберг. 


\section{$6{ }^{\text {TH }}$ CONFERENCE OF THE EUROPEAN SOCIOLOGICAL ASSOCIATION AGEING SOCIETIES, NEW SOCIOLOGY}

September 25-28, 2003

Murcia, Spain

\section{Coordinators for Economic Sociology Section:}

Sokratis Koniordos

Email: skoni@social.soc.uoc.gr

Patrick Aspers

Email: aspers@,sociology.su.se

http://www.valt.helsinki.fi/esa/ecs.htm

More information about the conference can be found at: http://www.um.ed/ESA, and about Murcia region at: http://www.carm.es 